UNIVERSIDADE DE SÃO PAULO

FACULDADE DE FILOSOFIA, LETRAS E CIÊNCIAS HUMANAS

DEPARTAMENTO DE LINGUÍSTICA

PROGRAMA DE PÓS-GRADUAÇÃO EM SEMIÓTICA E LINGUÍSTICA GERAL

PRISCILA LIMA PIRINI

CONSTRUÇÕES EXPERIENCIAIS DATIVAS EM GEORGIANO

E OUTRAS LÍNGUAS:

UMA ANÁLISE SOB O OLHAR DA LINGUÍSTICA COGNITIVA. 
PRISCILA LIMA PIRINI

\title{
CONSTRUÇÕES EXPERIENCIAIS DATIVAS EM GEORGIANO E OUTRAS LÍNGUAS: UMA ANÁLISE SOB O OLHAR DA LINGUÍSTICA COGNITIVA.
}

\author{
Versão corrigida
}

Tese apresentada ao Programa de PósGraduação em Semiótica e Linguística Geral da Faculdade de Filosofia, Letras e Ciências Humanas da Universidade de São Paulo, para obtenção do título de Doutor em Letras.

Área de concentração: Semiótica e Linguística Geral.

Orientador: Prof. Dr. Paulo Chagas de Souza. 
Autorizo a reprodução e divulgação total ou parcial deste trabalho, por qualquer meio convencional ou eletrônico, para fins de estudo e pesquisa, desde que citada a fonte.

Catalogação na Publicação

Serviço de Biblioteca e Documentação

Faculdade de Filosofia, Letras e Ciências Humanas da Universidade de São Paulo

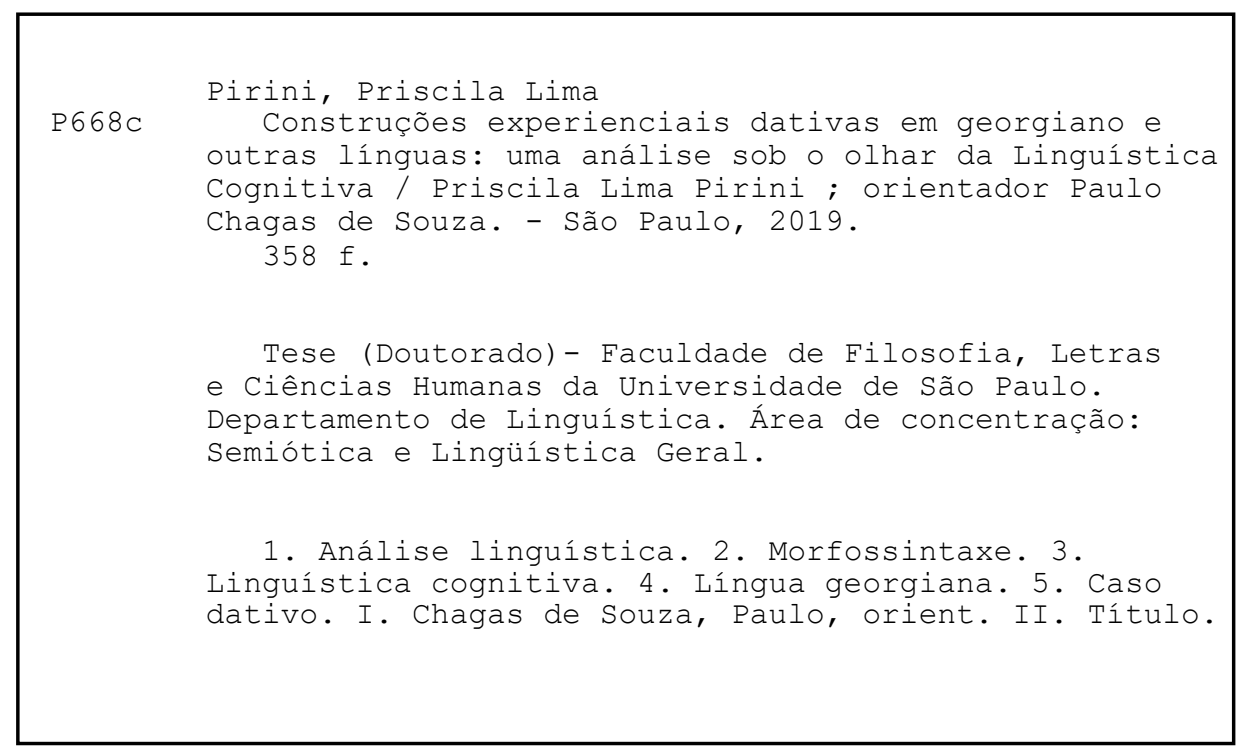




\section{ENTREGA DO EXEMPLAR CORRIGIDO DA DISSERTAÇÃO/TESE}

\section{Termo de Ciência e Concordância do (a) orientador (a)}

Nome do (a) aluno (a): _Priscila Lima Pirini

Data da defesa: __11_/__12_/_2019_

Nome do Prof. (a) orientador (a):_Paulo Chagas de Souza

Nos termos da legislação vigente, declaro ESTAR CIENTE do conteúdo deste EXEMPLAR CORRIGIDO elaborado em atenção às sugestões dos membros da comissão Julgadora na sessão de defesa do trabalho, manifestando-me plenamente favorável ao seu encaminhamento e publicação no Portal Digital de Teses da USP.

São Paulo, _11___01___ 2020

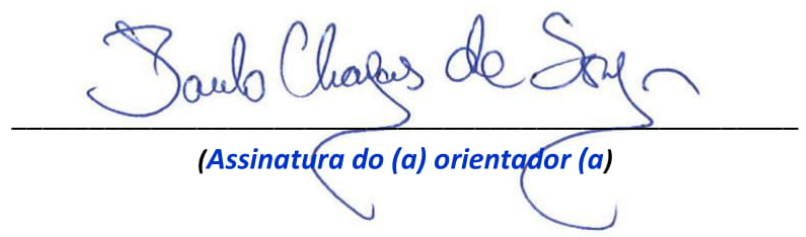


Nome: PIRINI, Priscila Lima.

Título: Construções experienciais dativas em georgiano e outras línguas: uma análise sob o olhar da Linguística Cognitiva.

Tese apresentada ao Programa de PósGraduação em Semiótica e Linguística Geral da Faculdade de Filosofia, Letras e Ciências Humanas da Universidade de São Paulo, para obtenção do título de Doutor em Letras.

Aprovada em:

Banca examinadora:

Prof. Dr.

Instituição:

Prof. Dr.

Instituição:

Prof. Dr.

Instituição: 


\section{AGRADECIMENTOS}

À Coordenação de Aperfeiçoamento de Pessoal de Nível Superior (CAPES), pela bolsa concedida que permitiu a dedicação exclusiva a esta pesquisa.

Ao meu orientador, Prof. Dr. Paulo Chagas de Souza, que tem me acompanhado desde a graduação, pelo apoio, compreensão, paciência, confiança, aprendizado e acolhimento.

À instituição sede em que esta pesquisa se realizou, Faculdade de Filosofia, Letras e Ciências Humanas da Universidade de São Paulo, por possibilitar o desenvolvimento integral da pesquisa e proporcionar um ambiente rico em discussões e conhecimento.

Aos professores do Departamento de Linguística, em especial, Prof. ${ }^{a}$ Dr. ${ }^{a}$ Ana Paula Scher e Prof. ${ }^{a}$ Dr. ${ }^{a}$ Esmeralda Vailati Negrão, por seus conselhos e orientação em exame de qualificação e durante todo o decorrer desta pesquisa e de minha formação. Sem sua inestimável participação e presença, a realização plena deste trabalho não teria sido possível.

A todos que contribuíram de alguma forma para minha formação acadêmica como aluna e pesquisadora.

À minha família querida, meus pais e irmã, pela presença, amor, carinho e paciência, e por terem feito, e ainda fazerem, minha vida mais completa e feliz.

A Herbert Leonardo Radeck, pela parceria e companheirismo durante esses anos, estando do meu lado em todos os momentos.

Por fim, dedico este trabalho às línguas do mundo, cuja gramática, diversidade e complexidade sempre me fascinaram e ainda continuam a me surpreender e me instigar. 


\section{RESUMO}

PIRINI, P. L. Construções experienciais dativas em georgiano e outras línguas: uma análise sob o olhar da Linguística Cognitiva. 2019. 358 f. Tese (Doutorado) Faculdade de Filosofia, Letras e Ciências Humanas da Universidade de São Paulo, São Paulo, 2019.

O objeto de estudo deste trabalho compreende construções experienciais (abarcando, em particular, eventos emocionais, de sensação física, de cognição e percepção) em que o experienciador do evento é marcado com o caso dativo. No georgiano, uma língua falada no sul do Cáucaso e foco principal de análise, esse fenômeno é pervasivo. Assim, uma sentença como 'Os garotos amam a menina' seria equivalente em georgiano a 'bich'-eb-s (garoto-PL-DAT) uqvar-t (amar-PL.DAT) gogona (menina.NOM)', em que o estímulo ocorre no caso nominativo e o experienciador no caso dativo, este último acionando concordância de plural no verbo através do sufixo - $t$. A partir da observação desse fenômeno, principalmente na língua georgiana e sincronicamente, busca-se explicar a natureza desse tipo de marcação distintiva por meio da caracterização do processo de significação codificado por essas construções. Para tanto, adotamos a perspectiva da Linguística Cognitiva (em particular, a Gramática Cognitiva de Langacker $(1987 ; 1991 ; 2008))$ que vai trazer, dentre outras, as noções fundamentais de metáfora, construal, polissemia e categorização com limites difusos para a descrição e compreensão do significado das expressões, entendidas como pareamentos de forma (fonológica) e significado. Do objetivo primeiro de descrever as construções dativas experienciais em georgiano a partir de seu significado, pretende-se chegar ao objetivo mais amplo de lançar luz sobre a forma como conceitualizamos eventos experienciais nas línguas. Dessa forma, na medida do possível, um esforço será feito ao longo de todo este trabalho para trazer dados de outras línguas de famílias diversas (e também diacrônicos quando encontrados), já que acreditamos que uma perspectiva tipológica, através da observação de semelhanças e diferenças, é de suma importância para o enriquecimento e aprofundamento do entendimento de como eventos experienciais são conceitualizados e codificados linguisticamente.

PALAVRAS-CHAVE: georgiano, dativo, linguística cognitiva, gramática cognitiva, construções dativas, verbos psicológicos, morfossintaxe. 


\begin{abstract}
PIRINI, P. L. Experiential Dative Constructions in Georgian and other languages: an analysis under the framework of Cognitive Linguistics. 2019. $358 \mathrm{f}$. Tese (Doutorado) - Faculdade de Filosofia, Letras e Ciências Humanas da Universidade de São Paulo, São Paulo, 2019.

The object of study of this work comprises experiential constructions (covering, in particular, emotion events, physical sensations, cognition and perception events) whose experiencer occurs in the dative case. In Georgian, a language spoken in the South Caucasus and the main focus of analysis, this phenomenon is pervasive. Thus, a sentence such as 'The boys love the girl' would be in Georgian 'bich'-eb-s (boy-PLDAT) uqvar-t (love-PL.DAT) gogona (girl.NOM)', the stimulus appearing in the nominative case and the experiencer in the dative case which triggers plural agreement in the verb through the suffix $-t$. From the observation of this phenomenon, mainly in the Georgian language and synchronically, we seek to explain the nature of this type of distinctive marking through the characterization of the meaning process coded by these constructions. For this purpose, we adopt the perspective of Cognitive Linguistics (in particular, Langacker's Cognitive Grammar (1987; 1991; 2008)) which brings, among others, the fundamental notions of metaphor, construal, polysemy and categorization with fuzzy boundaries for the understanding and description of the meaning of expressions, conceived as pairings of (phonological) form and meaning. From this first objective of describing experiential dative constructions in Georgian through their meaning, it is intended to arrive at the broader objective of shedding light on how we conceptualize experiential events. Thus, as far as possible, an effort will be made throughout this work to bring data from other languages (and also diachronic) of different language families, as we believe that a typological perspective, observing similarities and differences, is of great importance for enriching and deepening the understanding of how experiential events are conceptualized and linguistically coded.
\end{abstract}

KEY-WORDS: Georgian, dative, cognitive linguistics, cognitive grammar, dative constructions, psychological verbs, morphosyntax. 


\section{LISTA DE FIGURAS}

Figura 1: Verbos com marcação não canônica no georgiano com o experienciador no caso dativo 137

Figura 2: Caracterização esquemática de possessivo (LANGACKER, 2009, p. 84) ....178

Figura 3: Caracterização do protótipo de possessivo (LANGACKER, 2009, p. 84) ....179 Figura 4: Possessivo nominal, possessivos oracionais com o verbo 'ter' e possessivos locativos com o verbo 'ser', respectivamente (LANGACKER, 2009, p.89) 180

Figura 5: Caminho evolutivo: predicado fonte, protótipo de possessivo e caracterização esquemática do possessivo (LANGACKER, 2009)

Figura 6: Distinção entre as noções locativa e existencial (LANGACKER, 2009, p.99)

Figura 7: Representações das preposições above, beside, in e representação esquemática locativa. (LANGACKER, 2009, p.100)

Figura 8: Esquema de transferência de verbos como 'dar' (MALDONADO, 2002)....269

Figura 9: Esquema de verbos hiperativos como gustar (MALDONADO, 2002).........278

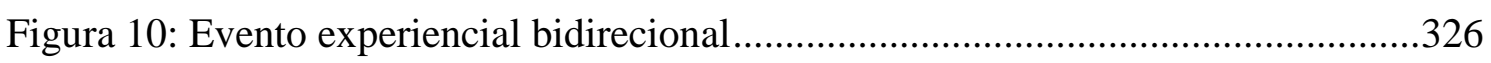

Figura 11: Evento experiencial bidirecional: evento causado externamente .................331

Figura 12: Evento experiencial bidirecional: evento a surgir do experienciador ...........332 


\section{LISTA DE TABELAS}

Tabela 1: Metáforas de anger 'raiva' com base em Kövecses (2005)...........................53

Tabela 2: Metáforas de love ‘amor' com base em Kövecses (2005) ................................53

Tabela 3: Marcação de caso de acordo com a classe e série. ........................................110

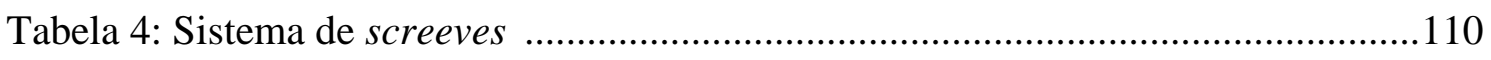

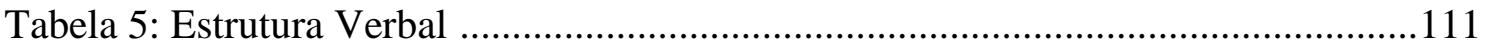

Tabela 6: Afixos de Concordância ………............................................................... 112

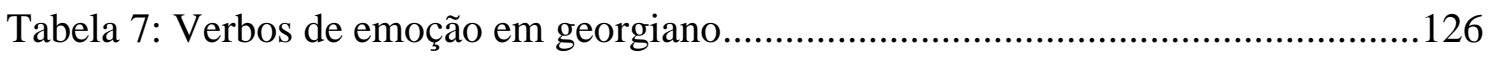

Tabela 8: Verbos de sensação física em georgiano ...................................................129

Tabela 9: Verbos de cognição em georgiano.................................................................130

Tabela 10: Verbos de percepção em georgiano..........................................................131

Tabela 11: Verbos de modalidade em georgiano. ......................................................132

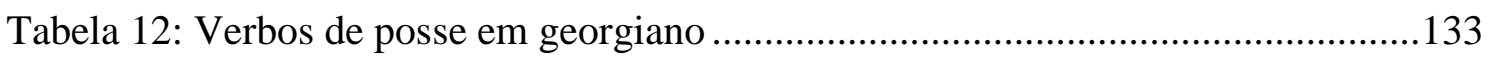

Tabela 13: Verbos de estados ontológicos em georgiano...........................................133

Tabela 14: Verbos de estados atitudinais em georgiano..............................................134

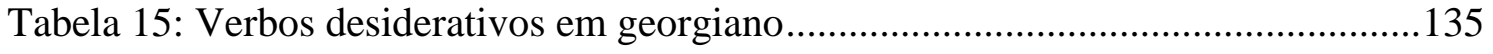

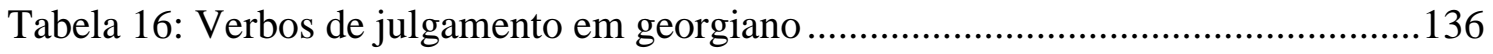

Tabela 17: Verbos codificando eventos não volitivos ..................................................208

Tabela 18: Concordância com objeto de terceira pessoa - Séries I do presente (padrão

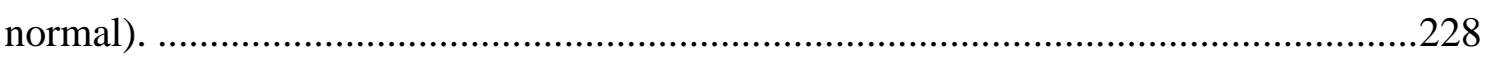

Tabela 19: Concordância com o sujeito de terceira pessoa (objeto indireto no dativo) -

Séries III do evidencial (padrão de inversão) .............................................................228

Tabela 20: Padrões de concordância de verbos indiretos no georgiano antigo (TUITE,

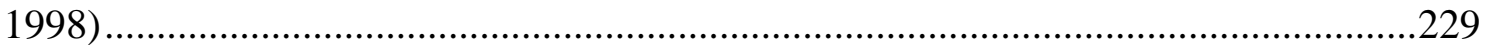

Tabela 21: Padrões de concordância de verbos indiretos no georgiano moderno (TUITE,

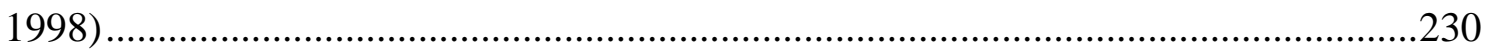

Tabela 22: Verbo $a$-shen-eb-s 'construir' nas três Séries.............................................23

Tabela 23: Verbos psicológicos com morfologia de outras Classes verbais .................252 


\section{ABREVIATURAS}

1A, 3A, 1B, 3B, etc: conjunto A de afixos de concordância e conjunto $\mathrm{B}$ de afixos de concordância, lê-se 'primeira pessoa do conjunto A', 'terceira pessoa do conjunto B', etc., abreviaturas seguidas usualmente pelo caso gramatical do argumento, i.e., 3ANOM, 3BDAT, etc.;

ABL: ablativo

ABS: absolutivo

ACC: acusativo

AFF: afectivo

AOR: aoristo

CAUS: causativo

COM: comitativo

CONVB: converbo

COP: cópula

DAT: dativo

DEB: debitivo

DEF: definido

DEM: demonstrativo

DESIS: desiderativo

DUR: durativo

ERG: ergativo

FEM: feminino

GEN: genitivo

ILL: ilativo

IMP: imperativo

IMPF: imperfeito

INC: incoativo

INDIC: indicativo

INFIN: infinitivo

INSTR: instrumental

INTR: intransitivo

INVOL: involuntário

LOC: locativo

MASC: masculino
NEG: negativo;

NEUT: neutro;

NOM: nominativo;

OBL: oblíquo;

PART: particípio;

PAST: passado;

PERF: perfeito;

PL: plural;

POSP: posposição;

POSS: possessivo;

POSTEL: postelativo;

PRES: presente;

PREP: preposição;

PREPOS: caso prepositivo

PV: preverbo;

REFL: reflexivo;

SA: aumento de radical;

SG: singular;

SM: marca de screeve;

ST: sufixo temático;

SUBJUN: subjunctivo;

TOP: tópico;

TR: transitivo;

VOC: vocativo;

VPR: vogal pré-radical. 


\section{TRANSLITERAÇÃO}

\begin{tabular}{|c|c|c|c|}
\hline $\begin{array}{l}\text { Alfabeto } \\
\text { georgiano }\end{array}$ & Transliteração & $\begin{array}{l}\text { Alfabeto } \\
\text { georgiano }\end{array}$ & Transliteração \\
\hline$s$ & $\mathrm{a}$ & b & $\mathrm{s}$ \\
\hline 8 & $\mathrm{~b}$ & $\mathcal{O}$ & $\mathrm{t}^{\prime}$ \\
\hline 8 & g & $y$ & $\mathrm{u}$ \\
\hline$@$ & $\mathrm{~d}$ & O3 & $\mathrm{p}$ \\
\hline 9 & e & $\mathrm{d}$ & $\mathrm{k}$ \\
\hline 3 & $\mathrm{v}$ & & gh \\
\hline 8 & $\mathrm{z}$ & y & $\mathrm{q}$ \\
\hline o) & $\mathrm{t}$ & ฮ & $\mathrm{sh}$ \\
\hline $\mathrm{O}$ & $\mathrm{i}$ & $h$ & ch \\
\hline 3 & $\mathrm{k}^{\prime}$ & 3 & $\mathrm{c}$ \\
\hline m & 1 & $\partial$ & $\mathrm{dz}$ \\
\hline$\partial$ & $\mathrm{m}$ & 6 & $c^{\prime}$ \\
\hline 5 & $\mathrm{n}$ & $\mathfrak{F}$ & ch' \\
\hline$m$ & o & $b$ & $\mathrm{x}$ \\
\hline 3 & $\mathrm{p}^{\prime}$ & $x$ & $\mathrm{j}$ \\
\hline I & $\mathrm{zh}$ & 3 & $\mathrm{~h}$ \\
\hline m & $\mathrm{r}$ & & \\
\hline
\end{tabular}




\section{SUMÁRIO}

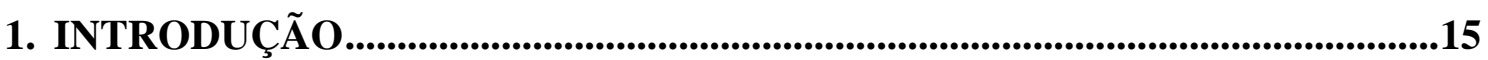

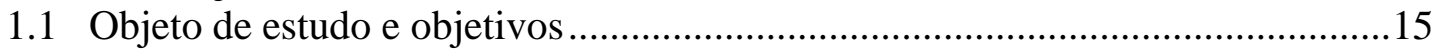

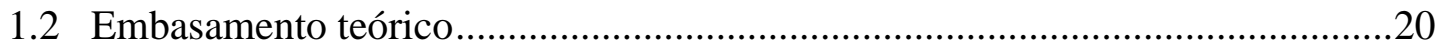

1.3 Metodologia e organização da tese ..........................................................20

2. INTRODUÇÃO À GRAMÁTICA COGNITIVA....................................................22

2.1 A Linguística Cognitiva como movimento teórico.............................................22

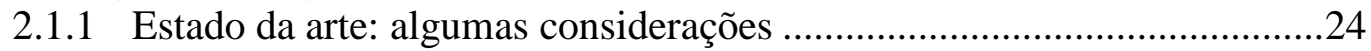

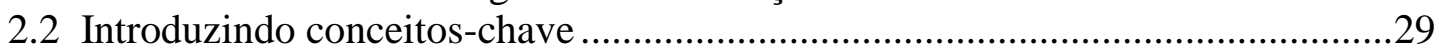

2.2.1 Unidades, arraigamento e esquematização na Gramática Cognitiva .......29

2.2.2 Categorização na Linguística Cognitiva .................................................33

2.2.3 Construções como pareamentos de forma e significado..........................36

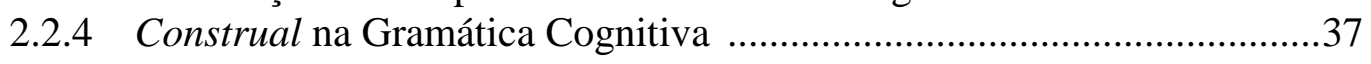

2.2.5 Domínios (domain) e arquétipos conceituais .........................................43

2.2.6 Cadeia de ação e modelo de evento canônico na GC ...............................44

2.2.7 Metáfora conceitual na Linguística Cognitiva............................................ 48

3. VERBOS PSICOLÓGICOS: REVISÃO DA LITERATURA ................................57

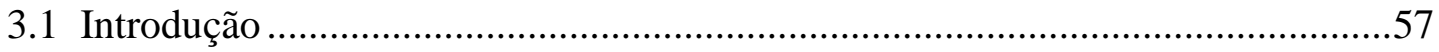

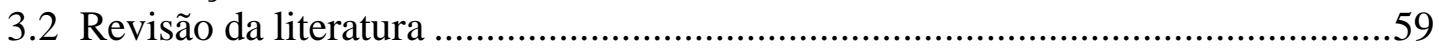

4. INTRODUÇÃO À GRAMÁTICA DO GEORGIANO ........................................107

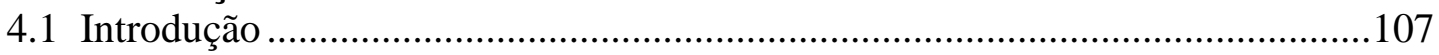

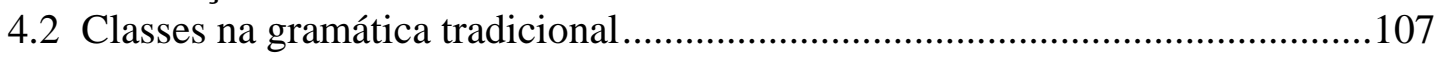

4.3 Classes: marcação de caso e concordância em georgiano ..................................109

4.3.1 Marcação de caso ............................................................................109

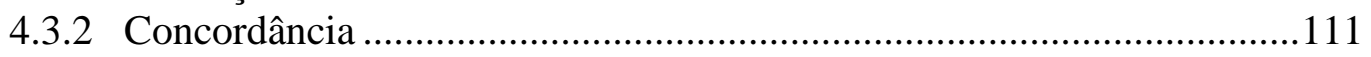

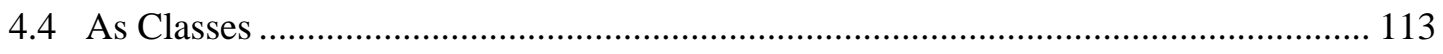

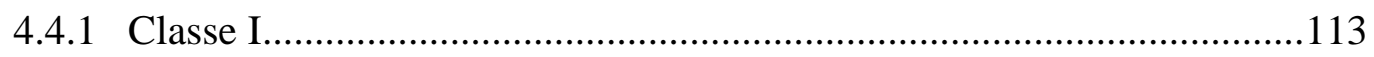

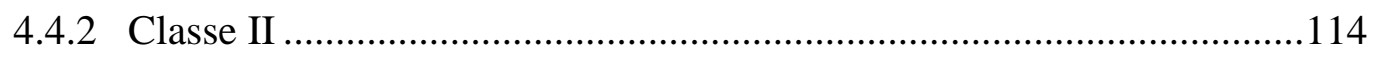

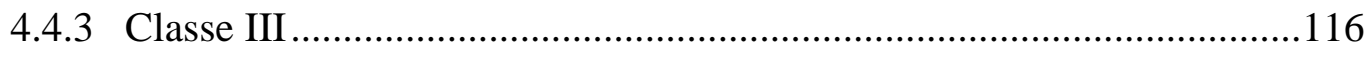

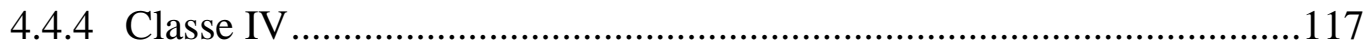

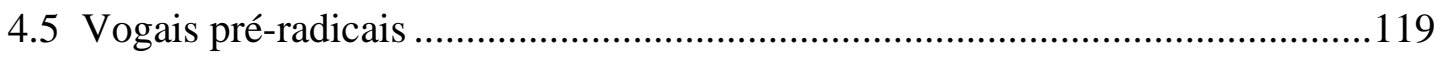

\section{VERBOS COM MARCAÇÃO NÃO CANÔNICA (DATIVA) EM}

GEORGIANO ...............................................................................................................123

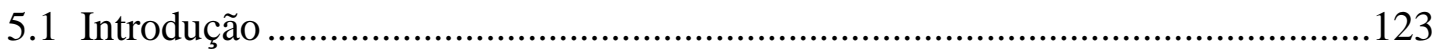

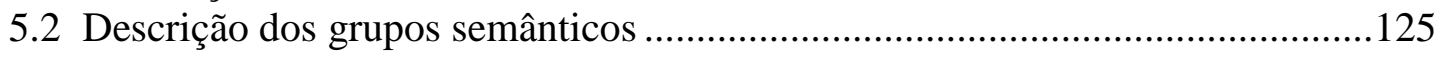

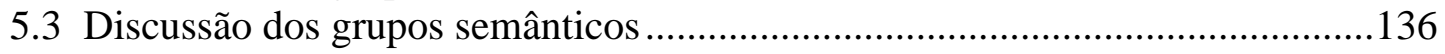

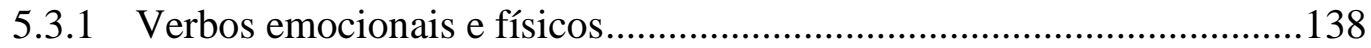

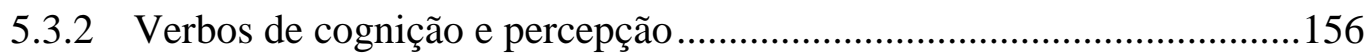

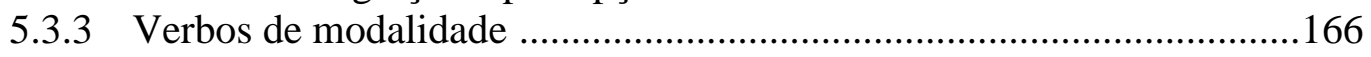

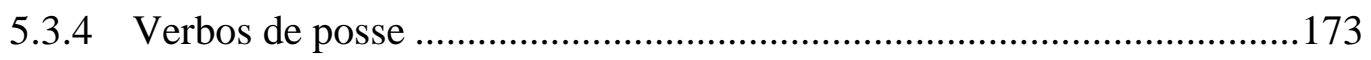

5.3.4.1 Pontos de referência e posse na GC .....................................177

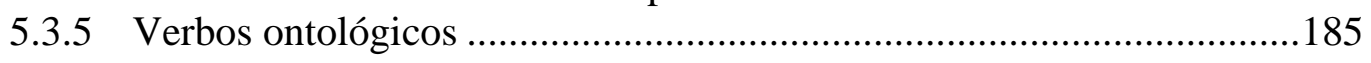




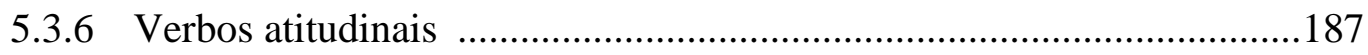

5.3.7 Verbos desiderativos e de julgamento ..............................................188

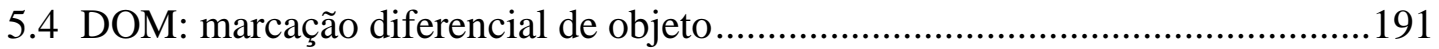

5.5 A importância da noção de volição em construções marcadas não canonicamente

5.6 Mudança sintática em construções dativas na história do georgiano ................216

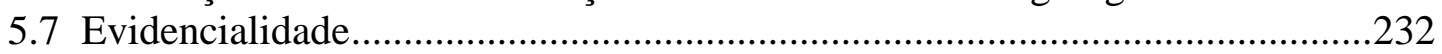

5.8 Causatividade e verbos causativos indiretos em georgiano ..............................240

6. VERBOS EXPERIENCIAIS: OUTRAS DISCUSSÕES RELEVANTES ........251

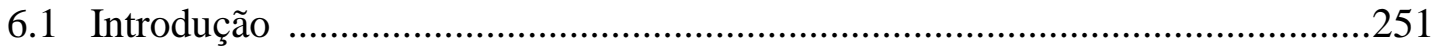

6.2 Outras construções com verbos experienciais nas línguas ...............................251

6.3 Análise de Maldonado (2002) e relação com outras construções com dativos 268

6.4 Sobre a relação próxima entre dativos e locativos............................................280

6.5 A esfera ativa e a esfera circunstancial: o papel de locativos e adposições......285

7. A CONCEITUALIZAÇÃO DE EVENTOS EXPERIENCIAIS ........................291

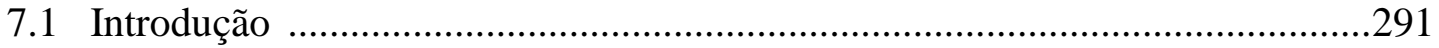

7.2 Eventos experienciais concebidos como causados externamente: introdução e conexão com construções experienciais dativas (e locativas) ..................................292

7.3 Bidirecionalidade na conceitualização de eventos experienciais ......................302

7.4 Locais e sua conexão conceitual com experienciadores e com a noção de

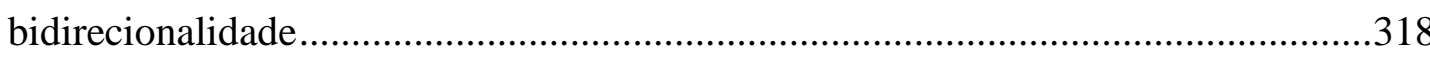

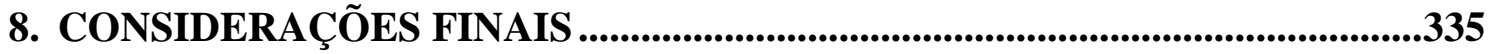

REFER̂̂NCIAS BIBLIOGRÁFICAS ...................................................................337 


\section{INTRODUÇÃO}

\subsection{Objeto de estudo e objetivos.}

O objeto de estudo deste trabalho são as construções exemplificadas pela sentença abaixo proveniente da língua georgiana, uma língua sul-caucasiana (kartveliana), falada no sul do Cáucaso:

$\begin{array}{lll}\text { bich'-eb-s } & \text { u-qvar-t } & \text { gogona } \\ \text { garoto-PL-DAT } & \text { VPR-amar-PL } & \text { menina.NOM }\end{array}$

Os garotos amam a menina.

O que torna essa construção especial na literatura linguística é a marcação não canônica de caso, por meio do dativo, do sujeito lógico da sentença 'os garotos'.

$\mathrm{Na}$ literatura linguística, 'construções dativas' são usualmente referidas como aquelas que contêm o argumento considerado como sujeito marcado com o dativo.

Esse fenômeno ocorre de forma notável tipologicamente, particularmente, com verbos considerados experienciais, isto é, verbos que denotam algum tipo de estado emocional, físico ou cognitivo, sendo o experienciador desse estado aquele marcado com o caso dativo.

A língua georgiana é um caso em questão, em que verbos com sujeitos dativos usualmente expressam sensações involuntárias, sintomas, emoções, estados (mentais, físicos), dentre outros. Estruturalmente, essas construções experienciais dativas também apresentam a peculiaridade de sofrerem 'inversão' em todas as Séries (conjuntos de tempos verbais). Inversão na literatura da língua é quando o sujeito lógico é marcado com o caso dativo e o objeto com o caso nominativo, o contrário, por exemplo, da marcação de um verbo canônico transitivo em georgiano.

Outro dado interessante a respeito da estrutura dessas construções em georgiano é a concordância do nominal dativo no verbo. Atente, em particular, para a 
concordância, no verbo, com o nominal dativo no plural através do morfema de plural - $t$ no exemplo acima.

Essa concordância atesta uma preferência de concordância no verbo com o nominal dativo, o que não ocorria no georgiano antigo.

Observe que, em georgiano, tanto sujeito quanto objeto (e, por vezes, objeto indireto) podem acionar concordância no verbo. No entanto, a estrutura verbal comporta um número limitado de slots verbais que são ocupados por morfemas específicos (dentre eles os de concordância), acarretando uma competição por esses slots quando há a possibilidade de mais de um morfema de concordância ocupar o mesmo slot.

Dessa forma, no georgiano antigo, era o nominal nominativo de terceira pessoa que tinha preferência por acionar um morfema de concordância no verbo. Situação contrária do que acontece no georgiano moderno, em que é o nominal dativo que tem essa preferência em construções experienciais dativas.

Essa mudança é interessante do ponto de vista do significado dessas construções dativas, já que aponta para uma crescente proeminência conceitual do participante codificado com o caso dativo.

$\mathrm{Na}$ literatura linguística do georgiano, essa mudança nos padrões de concordância carece de uma explicação que leve em consideração o significado das construções dativas experienciais, i.e., qual é a razão conceitual, em primeiro lugar, de haver essa marcação não canônica e o que essa maior saliência sintática do nominal dativo observada nos diz a esse respeito?

Dessa forma, o objetivo primeiro desta tese é caracterizar conceitualmente as construções experienciais e, em específico, as construções experienciais dativas em georgiano.

Observe que, por caracterização conceitual, queremos dizer que visamos descrever as construções experienciais dativas do ponto de vista de seu significado. Como suporte a esse objetivo, usaremos a Linguística Cognitiva, movimento teórico que será introduzido no capítulo 2, como ferramenta teórica que nos auxiliará na caracterização pretendida, visto que a teoria compartilha preceitos importantes com aqueles aqui adotados, como a importância dada ao significado na codificação e mudança linguística.

Dessa forma, o principal intuito é descrever o significado das construções com experienciadores no dativo e, como objetivo mais amplo, lançar luz sobre a forma como conceitualizamos eventos experienciais nas línguas. 
Observe que descrever tanto as construções experienciais com dativos quanto a codificação de eventos experienciais como um todo é uma tarefa particularmente complexa dada a diversidade com que esses eventos são relacionados e codificados nas línguas. Tanto é assim que a literatura linguística que trata de um e de outro é vastíssima, sendo necessário fazer recortes sobre diferentes construções ou fenômenos a serem focados.

Dessa forma, há dois eixos através dos quais é possível e bastante comum relacionar o objeto descrito acima (i.e, as construções experienciais dativas), seja por similaridades, seja por oposições. Primeiro, não há uma única forma de se codificar eventos experienciais nas línguas. Segundo, as construções exploradas pelas línguas não são exclusivas desses tipos de eventos.

Nesse primeiro eixo, além da construção dativa (contendo um experienciador no dativo), é possível encontrar eventos experienciais marcados através de outros tipos de marcação não canônica, por exemplo, o experienciador no caso genitivo ou no acusativo. E não raro, há a coexistência desse tipo de marcação não canônica com uma marcação canônica na língua (seja por meio do caso nominativo ou ergativo). Além de marcação de caso, encontram-se ainda nas línguas construções transitivas com dois argumentos (variando frequentemente o posicionamento do argumento experienciador, ora em função de sujeito (SubjExp), ora em função de objeto (ObjExp)), intransitivas com um participante, construções perifrásticas (compostos de um verbo e um nome ou adjetivo, por exemplo), construções médias, etc.

Essa variação encontrada tanto internamente nas línguas quanto translinguisticamente levanta algumas questões, por exemplo, internamente, quando a língua dispõe de mais de um desses recursos, em que medida poderia se considerar como equivalentes ou opostas em significado essas construções coexistentes? Translinguisticamente, considerando a variação encontrada através das línguas, seria possível encontrar similaridades ou mesmo diferenças sistemáticas em meio à diversidade?

No segundo eixo, há o fato de que, dado determinado recurso utilizado, ele não é somente utilizado para codificar eventos experienciais. Construções dativas, por exemplo, são amplamente conhecidas por seu uso em eventos de transferência, de posse, modais, dentre muitos outros. Assim como construções transitivas e médias são exploradas para codificar outros tipos de eventos que não, naturalmente, somente 
experienciais. Novamente, em que medida há variação e semelhança nessa rede de relações semânticas através das línguas e nas línguas?

Dada a complexidade dessas questões, existem na literatura linguística diferentes formas de se pensar essas relações e de responder a essas questões. No capítulo 3, será apresentada uma ainda pequena parte, mas significativa, de estudos feitos sobre o assunto de vertentes teóricas diferentes, para que seja oferecido um panorama da complexidade das questões envolvidas e para que possamos começar a discutir pontos importantes acerca da argumentação e caracterização conceitual defendida nesta tese.

Dadas justamente a complexidade e inviabilidade de se abordar todos os aspectos gerados por esses dois eixos através das línguas, justificando a necessidade de um recorte, ou seja, o estudo mais focado nas construções experienciais dativas em georgiano, acreditamos que um dado fenômeno linguístico não pode, e nem é possível, ser estudado em isolamento. Por essa razão, o esforço que almejamos realizar ao longo de toda esta pesquisa é a de fornecer, ainda que pontualmente, dados advindos desses dois eixos que irão indubitavelmente enriquecer e agregar ao entendimento, discussão e análise das construções dativas sob foco.

Dessa forma, tentaremos trazer dados, ao longo da tese, de outras construções experienciais, i.e., com marcações e estruturas outras que não somente aquela com experienciadores no dativo. Esse esforço será visto logo no capítulo 3, em que iremos rever estudos sobre verbos experienciais no geral.

Esse esforço de trazer dados de outras construções experienciais na medida do possível, i.e., dadas as limitações desta tese, acreditamos, foi fundamental para entendermos o fenômeno das construções experienciais dativas e a forma como eventos experienciais são conceitualizados e codificados nas línguas.

Outro esforço, e que vai além do recorte feito, foi o de trazer dados de línguas diversas e tipologicamente distantes para a discussão dos dados do georgiano e para a argumentação da caracterização conceitual das construções dativas e dos eventos experienciais, já que acreditamos que uma visão mais ampla e rica de dado fenômeno conceitual só pode ser alcançada se olharmos para esse fenômeno translinguisticamente.

Ademais, em relação ao segundo eixo acima citado, iremos também trazer dados e discussões de outras construções dativas, tais como aquelas que codificam eventos de transferência, de posse, modais, dentre outros, pois acreditamos que a polissemia do caso dativo é revelatória de seu importe conceitual, havendo semelhanças conceituais 
entre essas diferentes construções e que formam uma família de construções em georgiano (e, possivelmente, em outras línguas também).

Traçados aqui esses objetivos e esforços, começaremos discutindo o embasamento teórico mencionado acima no capítulo 2, cuja estrutura será explicitada na seção seguinte desta introdução.

No capítulo 3, faremos uma revisão de estudos relevantes e referenciais acerca dos verbos experienciais nas línguas, em que serão pontuados aspectos importantes de nossa argumentação e do significado dos eventos experienciais e de seus participantes.

No capítulo 4, dada a complexidade do sistema verbal da língua georgiana, faremos uma revisão de noções fundamentais da gramática tradicional do georgiano e de seu sistema verbal, apresentando as chamadas classes verbais, o sistema de marcação de caso e de concordância e as vogais pré-radicais.

No capítulo 5, será oferecida uma descrição das construções dativas experienciais, em que mostraremos quais grupos semânticos de verbos, agrupados por conveniência descritiva, instanciam essas construções em georgiano.

Feita essa descrição, que não pretende oferecer uma listagem exaustiva de verbos de cada grupo, mas sim representativa, discutiremos esses grupos de verbos em georgiano, apontando diferenças e semelhanças conceituais.

Nessa discussão, visando a caracterização conceitual de eventos experienciais, como foi dito acima, iremos trazer dados de outras línguas que foram encontrados e que enriquecerão o entendimento do fenômeno sob estudo.

Além da discussão desses grupos, também discutiremos no capítulo 5 a mudança sintática observada na história do georgiano mencionada acima; a importância da noção de volição nas construções dativas; a evidencialidade em georgiano; os verbos chamados de causativos indiretos em georgiano; e marcação diferencial de objeto (DOM).

No capítulo 6, reservamos algumas seções sobre aspectos mais gerais e que serão fundamentais para a caracterização conceitual de eventos experienciais e das construções dativas experienciais sob foco. Dentre eles, aspectos envolvendo construções experienciais com marcações e estruturas outras que não somente a dativa; a análise de Maldonado (2002) acerca da relação entre diferentes construções dativas no espanhol; a relação próxima entre locativos e dativos nas línguas em que serão trazidos dados de línguas leste-caucasianas; e uma discussão sobre o papel de locativos e adposições na gramática das línguas segundo a Gramática Cognitiva. 
Por fim, no capítulo 7, será discutida a caracterização conceitual de eventos experienciais com base nas discussões e considerações feitas no decorrer da tese.

\subsection{Embasamento teórico}

Como dito na seção anterior, a Linguística Cognitiva, mais especificamente a Gramática Cognitiva de Langacker, servirá como uma ferramenta para que possamos caracterizar a estrutura conceitual das construções dativas experienciais sob foco e os eventos experienciais no geral.

Em primeiro lugar, a escolha foi feita, pois compartilhamos o preceito de que o significado deve ser o ponto de partida para a caracterização e descrição dos fenômenos linguísticos. Acreditamos, assim, que um melhor entendimento do fenômeno aqui estudado (as construções dativas experienciais) e da mudança observada no georgiano pode ser alcançado se levarmos em consideração a estrutura conceitual dessas construções.

O capítulo 2 tem o intuito de explicitar preceitos e conceitos fundamentais da Linguística Cognitiva (e, por conseguinte, da Gramática Cognitiva) e que serão retomados ao longo da tese em nossa argumentação, sendo essa introdução importante, pois fornecerá as bases de como entendemos noções básicas como categorias com limites difusos, construções como pareamentos de forma fonológica e significado, significado, conceitualização, construal, domínios e arquétipos conceituais, arraigamento e esquematização, o modelo de evento canônico e estrutura de eventos e metáfora conceitual.

\subsection{Metodologia e organização da tese}

Os dados que foram utilizados e que deram embasamento à pesquisa foram retirados sobretudo da literatura linguística (incluindo dicionários e gramáticas) que tem tratado, por diferentes motivações, das línguas e dos fenômenos em questão. Dessa 
forma, o levantamento bibliográfico proposto por esta pesquisa abrange a soma de dados que foi necessária como embasamento à análise pretendida.

No caso dos dados provenientes do georgiano e português, foram também retirados dados de provedores de busca na internet, sendo a referência ao site de onde foi retirado o dado citada em notas de rodapé e logo após o exemplo.

Os dados retirados de outros autores foram explicitamente indicados, tendo a referência indicada logo abaixo do exemplo ou conjunto de exemplos. Na ausência de qualquer indicação, o exemplo ou dado foi obtido por meio de elicitação própria com falantes nativos.

Em relação à organização da tese, os capítulos a partir do terceiro incluem uma seção introdutória em que será exposto resumidamente o que será tratado naquele capítulo, tendo o intuito de situar o leitor e as ideias discutidas. 


\section{INTRODUÇÃO À GRAMÁTICA COGNITIVA}

\subsection{A Linguística Cognitiva como movimento teórico.}

O movimento teórico conhecido pelo termo Linguística Cognitiva evoca uma série de trabalhos iniciados na década de 70 por um conjunto de linguistas que compartilhava a visão de que a língua é parte da cognição humana e como tal, deve ser descrita e analisada com base em outros processos e habilidades cognitivas.

Resulta, dessa visão, um dos compromissos assumidos pela Linguística Cognitiva que é descrever as línguas humanas de acordo com princípios gerais da cognição, o que vai na direção contrária à tendência vigente na época de postular princípios específicos à linguagem.

Essa premissa estende-se para a gramática da língua, na medida em que sua própria estrutura vai ser correlata a processos cognitivos como categorização, atenção, percepção, etc.

Contrária à visão de que a sintaxe constitui um componente autônomo, governada por princípios próprios e independente da semântica e do léxico, a Linguística Cognitiva vai sustentar, como pressuposto fundamental, que a gramática, assim como o léxico, constitui uma relação de forma (fonológica) e significado. O que equivale a dizer que a gramática tem uma natureza inerentemente conceitual.

Desse modo, cada construção vai ter seu próprio importe conceitual, refletindo uma organização cognitiva particular. Assim, distinções formais observadas na língua vão espelhar, crucialmente, diferenças conceituais (ACHARD, 1998, xi).

O significado, portanto, torna-se central no estudo e análise da língua e de suas estruturas, assim como conceitos como metáfora, polissemia, conhecimento prévio, construal começam a ganhar espaço na descrição das estruturas linguísticas, sendo reconhecidos por sua natureza ubíqua.

Do mesmo modo, começou a ganhar notoriedade o caráter intrinsicamente experiencial e social/interativo na formação das expressões linguísticas, estando a língua e sua estrutura arraigadas no corpo, no uso e na comunicação.

Esse novo e frutífero campo de pesquisa foi aberto graças a diversos linguistas trabalhando em direções particulares e sob nomes por vezes diferentes, mas que 
trouxeram resultados convergentes e complementares. Charles Fillmore, por exemplo, com sua semântica de frames; George Lakoff (1987) e Lakoff \& Johnson (1980) com seus trabalhos referenciais sobre metáfora e metonímia; Ronald Langacker (1987) com o desenvolvimento da Gramática Cognitiva; Leonard Talmy (1988) com seu trabalho sobre dinâmica de forças e depois com a Semântica Cognitiva (2000); e Gilles Fauconnier (1994) com sua teoria sobre espaços mentais. ${ }^{1}$

Comum a essas linhas de pesquisa é a visão de que as línguas e seu sistema são intrinsicamente moldados pela cognição, pela experiência, pelo contexto social e comunicativo, logo sua descrição não pode ser dissociada desses aspectos.

Por essa perspectiva, o significado, sendo central, equivale à conceitualização, processo cognitivo pelo qual o significado de uma expressão linguística seria construído e que envolve não somente o conteúdo da situação ao qual se refere a expressão, mas também outros fatores como experiências e conhecimento prévios, contexto social, físico, etc. (EVANS \& GREEN, 2006, p.162; LANGACKER, 2002, p.2; 2008, p.4). Nas palavras de Talmy (2000a, p.4), o significado gerado por uma expressão linguística é intrinsecamente cognitivo, isto é, é abarcado por uma forma mais geral de concepção à qual impõe certa seleção ou restrição.

Assim, as palavras e expressões são apenas comandos, prompts, que dão origem à construção de significado que é extremamente rica e elaborada (EVANS \& GREEN, 2006).

Complementarmente, outro aspecto da conceitualização que desempenha papel central nos trabalhos, principalmente, de Langacker e Talmy, é aquele que concerne o modo como uma situação ou cena é construída e percebida, i.e., refere-se à nossa capacidade de estruturar o conteúdo dessa situação de diferentes modos, envolvendo diretamente o ponto de vista e percepção, além de pressupor certa escolha, daquele que é o sujeito da conceitualização (VERHAGEN, 2007).

A diversidade de operações desse tipo que as línguas são capazes de codificar pode ser observada por classificações abrangentes originadas a partir de linhas de pesquisa particulares, mas que refletem esse aspecto essencial da gramática. Por exemplo, a classificação de Langacker (2008) - a saber, 'proeminência', 'especificidade', 'perspectiva' e 'foco' -; e a classificação feita por Talmy (2000a) - a

\footnotetext{
${ }^{1}$ Vale mencionar linguistas funcionalistas como Givón, Paul Hopper, Sandra Thompson, Chafe, dentre outros que, sem dúvida, compartilham em muitos aspectos pressupostos com a Linguística Cognitiva, sendo ela própria considerada como uma teoria funcionalista (cf. LANGACKER, 2016).
} 
saber, 'estrutura configuracional', 'perspectiva', 'atenção' e 'dinâmica de forças'. Categorias como essas correspondem ou espelham fenômenos e processos mais gerais da cognição e experiência humana.

Se o significado - visto como um processo cognitivo elaborado - torna-se um meio de acesso ao modo como pensamos e percebemos o mundo ao nosso redor, a gramática - vista como tendo significado inerentemente -, consequentemente, também passa a ser um meio de não só compreender melhor nossa cognição e a vasta variedade de conceitualizações que somos capazes de gerar, mas igualmente a forma como organizamos e estruturamos essas informações. E isso se torna possível, sobretudo, porque a estrutura da língua nos dá meios de estruturar e codificar uma grande variedade dessas informações, nas palavras de Langacker:

\footnotetext{
Additionally, grammar allows us to construct and symbolize the more elaborate meanings of complex expressions (like phrases, clauses, and sentences). It is thus an essential aspect of the conceptual apparatus through which we apprehend and engage the world. And instead of being a distinct and self-contained cognitive system, grammar is not only an integral part of cognition but also a key to understanding it. (2008, p.3 e 4)
}

Através, portanto, de sua sistematicidade, organização e dos padrões que apresenta, a estrutura da língua, sua gramática, torna-se um meio fundamental e essencial de se apreender o funcionamento e os mecanismos envolvidos na produção de significado.

Um dos grandes interesses da Linguística Cognitiva que emerge, consequentemente, dessa concepção de língua, é observar como a gramática codifica e organiza processos cognitivos mais gerais e estruturas conceituais complexas, incluindo operações que mobilizam estruturações distintas desse conteúdo conceitual.

\subsubsection{Estado da arte: algumas considerações}

Divjak, Levshina e Klavan (2016) abrem a edição especial número 27 (4) do periódico Cognitive Linguistics sob o título Looking back, Looking Forward - e que 
versa sobre o atual estado da arte da Linguística Cognitiva (doravante LC) e seus desafios - com alguns questionamentos acerca de três eixos que formam a base sobre a qual a LC foi idealizada: o pressuposto de encarar a língua como parte da cognição humana, devendo ser descrita, portanto, com base em outras capacidades cognitivas; a visão de que a dimensão social molda a língua e suas estruturas; e as diferentes metodologias empregadas, introspecção e experimentação (como elicitação) em contraste com métodos quantitativos e baseados em corpus.

Em cada um desses eixos, há três dimensões a ser consideradas: estudar a sincronia, isto é, a língua num dado momento versus a diacronia (as mudanças que ocorrem ao longo do tempo); estudar fenômenos em uma língua particular versus em diversas línguas; estudar diferentes modalidades de língua, como o gesto.

Interessa-nos trazer as questões levantadas acima por Divjak, Levshina e Klavan (2016) e a subsequente discussão feita por alguns dos autores que compuseram esse volume especial, pois isso propicia uma reflexão sobre a teoria a ser empregada nesta tese e seus fundamentos, além de justificar alguns direcionamentos e decisões metodológicas que citamos na introdução (1.2).

A Linguística Cognitiva teve como ponto de partida análises de língua predominantemente baseadas na introspecção, em seu caráter sincrônico e focadas em línguas como o inglês. Com o tempo, no entanto, seu foco foi se expandindo voltandose a análises mais quantitativas - o que chamam de quantitative turn -, baseadas em corpus, diacrônicas e focadas em uma maior variedade de línguas.

Uma das questões levantada por Divjak, Levshina e Klavan (2016) é que, apesar de pressupostos, como o compromisso cognitivo, estarem na base da LC, nem sempre passaram, de fato, para a prática. Os autores chamam a atenção para a necessidade de mais interdisciplinaridade, por exemplo, com áreas como a psicologia e neurolinguística e seus desenvolvimentos.

A mesma crítica é feita em relação à atenção dada ao aspecto social e à utilização de dados de uso real. Mesmo tendo em sua base o princípio de que a gramática emerge do uso e da interação (LANGACKER, 1987; 2016), por um longo tempo esse princípio foi pouco levado, na prática, ao primeiro plano (DIVJAK, LEVSHINA, KLAVAN, 2016; LUODONPÄÄ-MANNI, PENTTILÄ e VIIMARANTA, 2017).

É apenas nas últimas décadas que a LC começou a presenciar o que chamam de social turn e quantitative turn. No primeiro, começou-se a buscar dados em contextos 
reais de uso e comunicação, focando em aspectos sociocomunicativos e de variação. O segundo, marcado pelo ano 2008 na revista Cognitive Linguistics (JANDA, 2013), representa a mudança em metodologia, voltando-se a métodos quantitativos e estatísticos de grandes porções de corpus, assim como estudos experimentais (DIVJAK, LEVSHINA, KLAVAN, 2016; LANGACKER, 2016).

Apesar das críticas, Divjak, Levshina e Klavan (2016) e Luodonpää-Manni, Penttilä e Viimaranta (2017) notam que os métodos usados pelos fundadores da LC como Lakoff (1987), Langacker (1987) e Talmy (1986) - baseados em exemplos construídos e na introspecção - são justificáveis e esperados na medida em que conciliar a busca de dados e a construção teórica é especialmente problemático, metodologicamente falando. Como é natural, os autores estavam voltados a dar as bases teóricas e analíticas da teoria, o que é essencial para que qualquer trabalho, quantitativo ou não, pudesse ser desenvolvido subsequentemente.

De fato, trabalhos fundadores discutidos no capítulo 3 desta tese, por exemplo, apesar de, em sua maior parte, serem baseados em exemplos construídos e introspecção (como criticado por Grafmiller (2013)) deram parte significativa da base de análise dos verbos psicológicos, possibilitando, inclusive, que trabalhos baseados em corpus, como o de Grafmiller (2013) (discutido no capítulo 3) e outros, fossem possíveis.

É justamente por essa razão que Langacker (2016, p.471) defende que a utilização de ambos os métodos, qualitativos (baseados na introspecção e na teorização) e quantitativos, é essencial ao campo da linguística e que mutuamente sustentam um ao outro, e adverte para as consequências de se priorizar apenas um dos métodos em detrimento do outro:

\footnotetext{
If purely qualitative concerns originally predominated in Cognitive Linguistics, the quantitative turn is now correcting the imbalance. Like any swing of the pendulum, this one brings with it the potential for unfortunate consequences. One is the temptation of doing "numbers just for numbers' sake", which is harmless but non-revelatory. More serious would be the emergence of a "more rigorous than thou" attitude, the notion that quantitative approaches are inherently "better" than others by virtue of being "scientific". This could lead to the marginalization of other sorts of investigation which are necessary to the overall enterprise.
}

Como Luodonpää-Manni, Penttilä e Viimaranta (2017) notam, métodos quantitativos não podem ser tomados como prova de verdade, nem como o único 
método confiável ou o mais 'objetivo'. Tanto métodos quantitativos quanto qualitativos são dependentes de certos pressupostos teóricos e a interpretação de dados quantitativos pressupõe um viés teórico, não sendo estritamente objetiva.

Langacker (2016) e Luodonpää-Manni, Penttilä e Viimaranta (2017) ainda observam que cada metodologia pode contribuir para o entendimento e descrição das línguas, possuindo vantagens e funções complementares. Além do mais, há uma divisão de trabalhos entre os diferentes métodos, cada um respondendo a questões de pesquisa distintas, mas que mutuamente se beneficiam.

Já em relação aos estudos diacrônicos, Winters (2010) também nota que, apesar de ter havido trabalhos que focavam em aspectos diacrônicos nos anos que se seguiram à expansão inicial da LC, ainda eram poucos os trabalhos publicados especificamente na área se comparados à quantidade expressiva de trabalhos sincrônicos na LC.

Com o desenvolvimento dos estudos na área, no entanto, começaram a surgir estudos que exploravam a indissociável relação entre sincronia e diacronia. Noções como categorização, extensão, metáfora e polissemia passaram a ganhar espaço na teorização da mudança linguística, discutindo-se a relação entre processos diacrônicos e a cognição.

Winters (2010) também chama a atenção para a constatação, compartilhada por muitos, de que sincronia e diacronia interagem de forma complexa e de que deveriam ser estudadas juntas e não separadas como normalmente é o caso.

Geeraerts (2010) vai enfatizar a importância de se focar, além da dimensão cognitiva, também na dimensão social e cultural na explicação dos processos de mudança linguística. Enfatiza, ainda, a importância de se estudar língua como um fenômeno histórico, o que é pressuposto pela LC dada sua visão de língua:

[...] the experiential nature of language involves a historically specific experience. If language both shapes and reflects human experience, then language is as historical as that experience: while part of the human experience is universal and biologically species-specific, another part is historical and cultural.

Assim como Divjak, Levshina e Klavan (2016) salientam a importância de se olhar para a língua em seus aspectos sincrônicos e diacrônicos, também argumentam sobre a importância de se olhar para várias línguas. 
Como Croft (2016) menciona, não é possível entender língua, sua variação e padrões, sem olhar para várias línguas, genética e arealmente distintas.

O desafio, no entanto, é achar fontes confiáveis e de uma quantidade grande de línguas, já que uma parcela significativa de línguas no mundo permanecem sem descrição, dificultando o trabalho do tipologista na identificação de padrões em línguas sem parentesco e de regiões diferentes e, também, de especificidades, sejam históricas, culturais ou geográficas.

Desse modo, como Croft (2016) e Aikhenvald \& Dixon (2017) colocam, a tipologia possibilita que se olhe para a mente e cognição humana, através, por exemplo, de como conceitualizamos certos conceitos, i.e, as dimensões conceituais que são recorrentes nas línguas, traçando pontos comuns e descontinuidades (DIVJAK, LEVSHINA, KLAVAN, 2016); ou de como categorias gramaticais se interrelacionam dentro das línguas, podendo indicar seu papel na cognição humana (AIKHENVALD \& DIXON, 2017).

Assim, a tipologia possibilita identificar tendências universais nas línguas (CROFT, 2016), nas palavras de Aikhenvald \& Dixon (2017, p. 2):

[...] linguistic typology aims at offering explanations - why there are certain linguistic universals and universal tendencies, and what their limits may be. There is here a direct link to how humans communicate and perceive the world around them, and how languages may reflect physical, social and cultural environment.

Dessa forma, os padrões e variação (e potenciais limites dessa variação) identificados translinguisticamente são uma janela para a cognição humana e para os processos de construção de significado. Como foi dito na seção anterior, central para a LC é o significado entendido como conceitualização.

Conceitualização não pode ser entendida como um processo que acontece apenas na cabeça dos falantes e dissociado do contexto. Conceitualização acontece no contexto e é aterrada na experiência, tanto corporal, como social e interativa, com a comunidade e com o meio.

Por essa razão, quando se diz que o foco central da LC é o significado, englobase o entendimento de que o significado das expressões reflete, sim, outras habilidades cognitivas, mas também, crucialmente, o corpo, o meio e a comunicação, não havendo 
separação estrita. O que é de se esperar, já que a própria cognição humana se processa e acontece no meio, no corpo e na interação.

Embora não nos seja possível preencher todas as lacunas e cumprir de forma satisfatória todas as expectativas traçadas acima, o esforço aqui feito, na investigação do objeto de estudo proposto e como mencionado no capítulo introdutório desta tese, será o de buscar dados de diversas línguas para evitar, ao máximo, conclusões que sejam favorecidas por um grupo específico de línguas.

Ademais, compartilhamos a ideia acima de que um estudo que abarque dados de outras línguas pode lançar luz sobre a forma como conceitualizamos nossa experiência, tanto em relação a especificidades quanto a possíveis universalidades.

$\mathrm{Na}$ busca dos dados dessas línguas, que serão essencialmente retirados da literatura linguística e de gramáticas, o intuito é que sejam trazidos não apenas dados sincrônicos, mas, em menor escala e quando disponíveis, dados diacrônicos. Além do mais, dados advindos de pesquisas baseadas no uso e quantitativas serão também buscados.

\subsection{Introduzindo conceitos-chave}

\subsubsection{Unidades, arraigamento e esquematização na GC}

$\mathrm{Na}$ GC, como parte do que Langacker (2008) chama de content requirementque visa restringir o aparato descritivo a apenas unidades de forma fonológica e significado -, as únicas estruturas atribuídas a um sistema linguístico são estruturas fonológicas, semânticas e relações simbólicas entre as duas. Uma relação simbólica, portanto, se dá entre uma estrutura fonológica e uma semântica, constituindo um pareamento de forma fonológica e significado (LANGACKER, 1987, 2008). Além desses elementos fundamentais, são ainda permitidas esquematizações dessas estruturas e relações de categorização entre elas.

Na GC, esquematização, assim como categorização, associação e automatização, são processos gerais da cognição humana manifestados intrinsicamente nas línguas: esquematização é nossa capacidade de extrair similaridades a partir de diferentes 
experiências, chegando-se a uma concepção mais abstrata que capta, dessa forma, as similaridades apreendidas entre essas experiências; categorização, como veremos na próxima seção, é nossa capacidade de apreender novas experiências a partir de experiências já vividas, de modo a poder criar associações; automatização ocorre quando dominamos, por meio de repetição e tentativa, estruturas complexas como no caso de arraigamento de unidades linguísticas, processo discutido abaixo; e associação é nossa capacidade de estabelecer conexões psicológicas, por exemplo, quando associamos uma estrutura fonológica a uma estrutura semântica em relações simbólicas.

Por essa perspectiva, o sistema linguístico seria composto por unidades linguísticas limitadas a pareamentos de forma fonológica e significado. Unidades linguísticas convencionais são rotinas cognitivas arraigadas, convencionais à medida que são padrões linguísticos estabelecidos em dada comunidade linguística, e arraigadas, dada a frequência em que são usadas, i.e., quanto mais frequentemente forem usadas ou expostas ao falante, maior o grau de arraigamento dessas unidades.

Por ser um modelo baseado no uso, as unidades linguísticas consistem em abstrações de diferentes graus de eventos de uso, emergindo a partir do arraigamento de aspectos comuns selecionados e apreendidos e tornando-se rotinas cognitivas.

$\mathrm{Na}$ GC, unidades linguísticas são todas aquelas expressões que foram arraigadas através de frequência e convencionalidade, compreendendo tanto itens lexicais, como cachorro, quanto expressões complexas, como, por exemplo, uma sentença transitiva regular. Decorre que, para a GC, a diferença entre gramática e léxico é uma questão de gradação e não de componentes discretos, delimitáveis. Desse modo, léxico e gramática (morfologia e sintaxe) formam um continuum, uma gradação em termos de complexidade simbólica e de especificidade, sendo plenamente reduzíveis a estruturas simbólicas, i.e., pareamentos de forma fonológica e significado.

Por rejeitar uma divisão categórica entre gramática e léxico e acreditar que a gramática é significativa inerentemente, a teoria também rejeita a visão formalista de que a gramática constitui um número limitado de regras e símbolos, sendo a partir desse conjunto restrito que um número infinito de sentenças ou estruturas pode ser produzido. Pela perspectiva formalista, a sintaxe seria, portanto, o domínio da regularidade e da previsibilidade e o léxico o domínio da irregularidade, da idiossincrasia. Na medida em que o léxico precisa ser armazenado, por ser irregular e imprevisível, a sintaxe, sendo regular e previsível, apenas necessitaria ser computada, gerada a partir de conjuntos de 
regras, excluindo-se a necessidade de armazenar as próprias estruturas geradas, pois a regra em si dispensa a listagem das formas produzidas a partir dela. ${ }^{2}$

Para a GC, regras não excluem a presença de listas e tanto o regular quanto o irregular são armazenados. Dessa forma, assim como um esquema mais abstrato como, por exemplo, de formação de plural em $-s$ do inglês é armazenado, as instâncias mais específicas como dogs e cats também seriam armazenadas. A generalização, captando a regularidade e recorrência dessa formação de plural, é apreendida pelo esquema.

Desse modo, um esquema de formação de plural em -s (ou mesmo um esquema de construções transitivas) é abstraído de instâncias mais específicas que têm em comum a formação de plural, tanto o esquema - presente de forma imanente em suas instanciações -, quanto as formas que o instanciam são armazenados como unidades, diferindo apenas no nível de abstração e especificidade. Nesse sentido, o modelo é bottom-up na medida em que as regras, esquemas mais abstratos extraídos de similaridades entre várias instâncias, emergem a partir do uso.

Assim, para GC, redundância de informação é um fato da língua e não pode ser ignorada a favor de economia, se o que se busca é plausibilidade cognitiva. Expressões mais específicas, arraigadas através de uso repetido, não são excluídas ao se abstrair um esquema de suas similaridades, tanto o esquema quanto suas instâncias coexistem na gramática do falante, sendo rotinas cognitivas arraigadas e facilmente retomadas. Por essa razão, o modelo é não reducionista, já que as instâncias não podem ser reduzidas ao esquema abstraído a partir delas.

Dessa forma, esquemas abstraídos a partir de similaridades apreendidas de diferentes instâncias mais específicas podem funcionar como templates para a interpretação de novas expressões (LANGACKER, 2008). Na GC, uma relação de categorização é dita de elaboração quando o esquema é plenamente manifestado no alvo, i.e., a instância que o elabora.

Em casos em que a categorização entre alvo e o esquema construcional evocado não é plena, pode ocorrer o que na GC é chamado de categorização por extensão, em que a categorização é apenas parcial, podendo haver elementos ou propriedades que diferem entre alvo e esquema construcional. Essa nova extensão do significado prototípico do esquema, inicialmente não arraigada, pode vir a se tornar uma unidade da

\footnotetext{
${ }^{2} \mathrm{O}$ contraste aqui feito ilustra as bases sobre as quais a Gramática Cognitiva foi idealizada, indo a CG contra algumas tendências teóricas mais preponderantes na época, tais como a Gramática Gerativa. Esse contraste, no entanto, não deve ser tomado como uma generalização no que tange as teorias formalistas e suas diferentes abordagens.
} 
língua à medida que começa a ser usada pelos falantes repetidamente. Em dado momento, é possível até mesmo que essa nova construção, tornando-se uma unidade da língua, venha a sancionar ela mesma novas expressões.

Assim, por ser um modelo baseado no uso, a partir do momento em que uma construção - que, por exemplo, antes era dada como não convencional - passa a ser usada pelos falantes com maior frequência, pode vir a ser arraigada como unidade, tornando-se parte das expressões convencionais daquela língua.

Naturalmente, o processo de categorização por parte dos falantes vai estar condicionado ao julgamento dos próprios falantes, ao contexto e a outros fatores como, por exemplo, o grau de arraigamento da unidade a ser evocada, i.e., quanto maior a frequência em que for usada, mais arraigada será e maior a probabilidade de ser evocada como unidade categorizante.

Dessa forma, esquemas, como unidades arraigadas, não só representam padrões de convencionalidade na língua, mas também participam no processo de mudança da língua, já que é a partir deles que novas expressões podem ser sancionadas e, com uso repetido, se tornarem arraigadas e parte da língua.

Dessa visão, decorre que tanto itens lexicais quanto construções gramaticais podem ser abstraídos através do reforço de similaridades apreendidas. Assim, esquemas construcionais são, por sua vez, abstraídos a partir de itens lexicais específicos, enquanto variantes lexicais resultam inicialmente de sua ocorrência em contruções diferentes, podendo formar em cada caso um network de variantes relacionadas em diferentes níveis de especificidade (LANGACKER, 2008).

Como Langacker (2009b) discute, um item lexical como o verbo é aprendido no contexto das construções em que aparece - não isoladamente - e vice-versa, e com o arraigamento e convencionalização do uso do verbo em determinada construção é que se pode dizer que o verbo tem o sentido associado àquela construção, em outras palavras, aquela construção, ou significado associado à construção, faz parte do network de construções, ou sentidos, associadas ao lexema verbal.

Uma categoria formada por um rede de construções relacionadas é chamada, na GC, de categoria complexa. Além de relações verticais, i.e., relações elaborativas instanciações mais específicas em relação aos esquemas mais abstratos - há também, em uma categoria complexa, relações horizontais, i.e., relações de extensão a partir de um protótipo - um esquema construcional que constitui o centro da categoria, sendo frequentemente instanciado e evocado para a sanção de novas expressões. Ademais, as 
relações em um network variam tanto em termos de especificidade, quanto em termos de tamanho, i.e., podendo incorporar outros elementos (LANGACKER, 2008).

No caso de um item lexical, por exemplo, um verbo, uma dimensão de sua complexidade é sua ocorrência em contextos estruturais maiores, assim, a descrição de um item lexical depende de conjunto de construções em que convencionalmente aparece. Esses construções juntamente com os sentidos que induzem formam um network. Como mencionado anteriormente, um item lexical, como um verbo, não é aprendido em isolamento, pelo contrário, sua aquisição se dá através das construções em que ocorre, tornando-se uma unidade através de arraigamento e convencionalização, i.e., sendo abstraído de eventos de uso a partir de similaridades apreendidas.

\subsubsection{Categorização na Linguística Cognitiva}

Categorização é uma capacidade cognitiva básica em que somos capazes de apreender e identificar similaridades e diferenças em experiências, eventos ou objetos, tendo, dessa forma, a capacidade de agrupá-los de formas distintas. Assim, toda vez que nos deparamos com uma experiência ou entidade nova, a tendência é procurarmos uma forma de estabelecer relações com outras experiências que já conhecemos, seja modificando categorias já existentes, seja criando novas. A própria língua é uma ferramenta de categorização, de forma que podemos categorizar objetos ou experiências através dela.

Dois estudos relativos à categorização vindos da psicologia, desenvolvidos por Eleanor Rosch, tiveram um grande impacto na semântica cognitiva: as categorias de nível básico e a teoria de protótipos. Esses estudos vieram a mudar completamente, pelo menos sob a perspectiva da Linguística Cognitiva, a concepção clássica de categorização, em que as categorias são definidas por um conjunto de condições ou propriedades necessárias e suficientes, ou seja, uma entidade pertenceria àquela categoria se tivesse todas aquelas propriedades. As categorias, assim, seriam consideradas como tendo limites bem definidos, rígidos. 
A teoria dos protótipos, em particular, vai mostrar que as categorias têm, pelo contrário, limites difusos ou fuzzy. ${ }^{3}$ Como Murphy (2002) observa, o mundo consiste de gradações e tons e uma rica mistura de diferentes propriedades que um número limitado de conceitos não daria conta de classificar.

As categorias, assim, não seriam definidas por um conjunto específico de propriedades, mas sim seriam estruturadas ao redor de protótipos, i.e., os membros considerados mais prototípicos daquela categoria. Por essa perspectiva, protótipos funcionam como pontos de referência para a classificação de instâncias não tão claras ou mais marginais à categoria. Cada categoria teria, portanto, membros mais típicos, extraídos de ocorrências reais (MURPHY, 2002).

Ainda em oposição à noção clássica de categorização, que pressupõe que os membros de uma dada categoria devam compartilhar um significado central, i.e., um significado ou conjunto de atributos comum a todos, está a noção de semelhança de família de Wittgenstein (TAYLOR, 2003). Para Wittgenstein, ainda que se possa associar à categoria certas similaridades de significado, não há um conjunto de propriedades comum a todos os membros de uma categoria, i.e., que todos necessariamente devam apresentar. Assim, os membros da categoria estariam ligados por uma rede de similaridades, em que alguns membros dividiriam certos atributos, outros dividiriam outros atributos, formando uma rede complexa de conexões (TAYLOR, 2003).

Murphy (2002) faz uma revisão na área da psicologia que estuda os conceitos discutindo algumas teorias de categorização em desenvolvimento e seu poder explicativo em relação aos fenômenos que apresenta. Em particular, a teoria de protótipos, a teoria de exemplares e a abordagem de conhecimento. Segundo o autor, as três pressupõem que as categorias de conceitos são caracterizadas por gradações e efeitos de tipicidade e que haverá casos limiares ou fronteiriços.

A diferença entre as três aparece na forma como essas abordagens vão explicar esses fenômenos. De forma bem concisa, a teoria de protótipos considera que cada categoria é definida por um protótipo que é uma representação sumária daquela categoria. A teoria de exemplares considera que cada categoria é definida através de um exemplar recuperado da memória (se similar ou não àquela memória). Na abordagem de

3 Murphy (2002), em sua discussão sobre categorias naturais, especialmente categorias de conceitos, discute as desvantagens de se assumir uma visão clássica de categorias discretas, observando que mesmo em campos considerados técnicos como biologia, astronomia, dentre outros, nem sempre há consenso na hora de definir as condições pelas quais um membro pertenceria a uma ou outra categoria. 
conhecimento, supõe-se que as pessoas usam seu conhecimento anterior para decidir se um item é membro ou não de determinada categoria e para aprender novas categorias.

Após discutir um número de desvantagens e vantagens de cada abordagem em relação aos fenômenos discutidos (por exemplo, categorias de nível básico, conceitos e seu aprendizado em crianças), Murphy (2002) propõe que uma teoria de conceitos deve integrar tanto a teoria de protótipos quanto a abordagem de conhecimento, já que, juntas e de forma integrada, dariam conta de grande parte dos fenômenos discutidos por ele.

Nessa visão integrada defendida pelo autor, não haveria necessariamente uma divisão de tarefas: protótipos sendo responsáveis por dar uma representação da categoria e o conhecimento sendo responsável por situar esse protótipo dentro de uma estrutura de conhecimento prévio mais abrangente, de modo a englobar tanto hierarquias (subordinações e superordenações) quanto conhecimentos específicos àquele domínio.

Pelo contrário, protótipos são integrados e influenciados pelo conhecimento, e vice-versa, já que, consequentemente, os protótipos também são parte do nosso conhecimento de mundo. ${ }^{4}$

Murphy (2002) ainda argumenta que a relação entre protótipo e conhecimento seria melhor integrada se o protótipo fosse representado por um esquema ao invés de listas de características mais comuns. Um esquema, para o autor, é uma estrutura de conhecimento e representa as dimensões de uma entidade. ${ }^{5}$

A proposta de integração argumentada por Murphy (2002) é, de certo modo, compatível com a visão da LC que vimos anteriormente, já que é enfatizado o papel crucial do conhecimento prévio na categorização linguística, o conhecimento enciclopédico. ${ }^{6}$ Como Evans \& Green (2006) discutem, os efeitos de tipicidade emergem de diferentes fontes, não necessariamente dissociáveis, mas integradas, dentre as quais, estão as categorias radiais e nosso conhecimento enciclopédico.

\footnotetext{
${ }^{4} \mathrm{O}$ autor observa que essa integração poderia ser considerada como aquela em que a informação conceitual seria uma grande estrutura de conhecimento e os conceitos (ou categorias) seriam nós dessa grande estrutura.

${ }^{5}$ Cf. Evans \& Green (2006) para uma revisão de argumentos contra uma equação direta da teoria de protótipos como representações de conhecimento.

${ }^{6}$ Para a LC, o significado é enciclopédico por natureza, i.e., as palavras não seriam entendidas como um conjunto fechado de significados, mas sim são meios de acesso a um vasto conhecimento que remete a um particular domínio (ou domínios) conceitual (EVANS \& GREEN, 2006). Dessa forma, o significado convencional seria apenas um 'prompt' para a construção de significado que, necessariamente, envolve e acontece no contexto.
} 


\subsubsection{Construções como pareamentos de forma e significado}

Uma construção é usualmente definida dentro da Gramática Cognitiva (doravante GC) como um pareamento de forma (fonológica) e significado, sendo considerada como uma unidade básica da língua. Como nota Taylor (2003), construções também devem ser consideradas como a formar categorias em termos de prototipicidade, i.e., em que certas instanciações seriam mais prototípicas ou melhores exemplos daquela construção do que outras.

Uma construção, assim definida - i.e., como um pareamento de forma fonológica e significado -, pode apresentar efeitos de prototipicidade tanto em termos de sua estrutura (elementos que a compõem) quanto de significado, nas palavras de Taylor (2003):

A construction may be used to express meanings which differ to a greater or lesser extent from the central specification. Similarly, the items which fill the construction slots may diverge from the formal specification of the prototype.

Construções são aprendidas no contexto de uso, i.e., a partir de eventos de uso em toda sua especificidade de significado. Uma construção, portanto, é aprendida com base nos elementos que mais recorrentemente ocorrem nela, isto é, os lexemas não são apenas inseridos em slots, eles, assim como a própria construção, são aprendidos no contexto das construções em que aparecem. É a partir das similaridades apreendidas em eventos de uso que um esquema daquela construção, unidade mais abstrata e menos rica ou específica em detalhes, pode ser abstraído. O esquema de uma construção - uma abstração de instâncias mais específicas -, tendo sido arraigado na língua através de uso repetido, pode ser, inclusive, usado para sancionar novas expressões.

Quanto aos elementos que ocorrem em uma construção, há construções lexicalmente específicas, por exemplo, certas expressões idiomáticas, e há construções menos específicas em termos dos elementos que nela ocorrem - i.e., são abstrações de instâncias mais específicas que contêm itens lexicais particulares -, apenas especificando, por exemplo, que dado elemento seja um sintagma nominal ou 
especificando a presença de certos verbos, como um verbo de movimento. Dessa maneira, passam a formar esquemas abstraídos a partir de similaridades observadas em diferentes instâncias que apresentam aquele mesmo tipo de configuração (TAYLOR, 2003).

Assim como uma construção tem seu esquema abstraído a partir dos elementos que recorrente e prototipicamente aparecem nela, um verbo ou os sentidos associados a ele são abstraídos a partir das construções em que esse verbo ocorre. Dessa forma, verbos são aprendidos no contexto das construções em que aparecem e vice-versa, e a partir do arraigamento e convencionalização do uso do verbo em determinada construção é que se pode dizer que o verbo tem o sentido associado àquela construção. Assim, aquela construção, ou significado associado à construção, faz parte dos sentidos associados ao lexema verbal através de esquematização.

Portanto, um item lexical, como um verbo, não é aprendido em isolamento. Pelo contrário, sua aquisição se dá através das construções em que ocorre, tornando-se uma unidade através de arraigamento e convencionalização, i.e., sendo abstraído de eventos de uso a partir de similaridades apreendidas. Assim, um verbo, por exemplo, pode ser referido como 'transitivo' apenas por ser usado prototipicamente em uma construção transitiva que na LC, aliás, é definida conceitualmente, sendo a noção de transitividade uma questão de gradação.

\subsubsection{Construal na Gramática Cognitiva}

Como apontamos anteriormente, construal é uma importante noção na Linguística Cognitiva, principalmente na Gramática Cognitiva (GC) de Langacker.

Construal é nossa capacidade de construir uma situação de modos distintos. Duas expressões podem evocar o mesmo conteúdo conceitual, porém diferir no modo como esse conteúdo é construído. Dessa forma, não basta descrever o significado de uma expressão com base apenas no seu conteúdo conceitual, o modo como esse conteúdo é construído é fundamental para sua caracterização plena.

Essas diferenças em construal têm reflexo na estrutura da língua, no modo como cada construção é estruturada. É por meio dos mecanismos oferecidos pela língua - que podem variar de língua para língua - que se torna possível estruturar conceitualizações 
distintas, refletindo diferentes modos de se construir eventos, seus participantes e a relação entre eles, desviando-se, inclusive, de construções mais canônicas.

Como apontamos anteriormente, na GC, significado é identificado com a conceitualização, um fenômeno mental, associada às expressões linguísticas, envolvendo uma série de fatores que a tornam complexa e rica e que vão além de somente uma descrição objetiva de uma cena, como o conhecimento anterior, apreensão de aspectos sociais, físicos e contextuais, além de fenômenos conceituais como metáfora. ${ }^{7}$ Assim, dada justamente a complexidade da conceitualização de eventos, é natural que no momento da codificação linguística, uma escolha, que não é neutra, seja feita em relação a quais aspectos daquela conceitualização o falante escolhe dar mais proeminência.

Como Langacker (1999) coloca, uma relação de construal se dá entre um conceitualizador e a conceitualização (em particular, o significado de uma expressão linguística). É por meio do construal utilizado que a perspectiva do falante, isto é, seu ponto de vista, torna-se parte da própria significação de determinada expressão.

Dessa forma, o significado de uma expressão envolve tanto seu conteúdo conceitual quanto o modo como esse conteúdo é construído. Nas palavras do autor:

\begin{abstract}
In regard to all of these [attention, selection, figure/ground organization, viewpoint, and level of schematicity] we are capable of making adjustments, thereby transforming one conceptualization into another that is roughly equivalent in terms of content but differs in how this content is construed. (LANGACKER, 1987, p.138).
\end{abstract}

É nessa escolha, com base nos mecanismos e convenções de cada língua, que se assenta a noção de construal. Ao conceitualizarmos um evento, por exemplo, tendemos a dirigir nossa atenção a certos aspectos em detrimento de outros, ocorrendo que uma porção acaba se sobressaindo em relação à outra, o que se sobressai é a figura, e o que permanece no background é o fundo.

Dessa forma, como aponta Langacker (1991, p.294), há uma relação interdependente entre construal e codificação linguística: como uma situação é

\footnotetext{
7 Dessa forma, como enfatiza Langacker (2008), o significado de uma expressão inclui não apenas o conteúdo diretamente codificado por seus elementos, como também qualquer estrutura adicional necessária para que a conceitualização seja coerente e reflita a intenção dos falantes.
} 
construída determina se uma expressão linguística é adequada para codificá-la, ao mesmo tempo, estruturas linguísticas carregam imagens convencionalizadas e impõem um determinado construal na situação codificada. ${ }^{8}$

Uma dimensão de construal que particularmente nos interessa é a de proeminência ou saliência. A noção, na GC, envolve nossa capacidade cognitiva de dirigir ou focar a atenção em diferentes elementos ou aspectos de uma situação. Dois tipos de proeminência são de particular interesse, profiling e alinhamento de trajetor e marco.

Em relações de profiling, perfil é a estrutura ou referente que uma expressão designa dentro de sua base conceitual, i.e., o conteúdo evocado. O perfil, dessa forma, é a estrutura mais saliente em referência à base, i.e., o elemento ao qual se dirige ou se foca a atenção. Por essa razão, uma expressão pode evocar o mesmo conteúdo e diferir apenas naquilo que é perfilado. ${ }^{9}$

Há expressões, no entanto, em que tanto o conteúdo, ou base conceitual, quanto o perfil são idênticos, nesses casos, a diferença semântica entre essas expressões reside em alinhamentos de trajetor e marco distintos.

Alinhamento de trajetor e marco é o tipo de assimetria, em termos de proeminência, que se observa entre os participantes de uma relação perfilada por um verbo.

$\mathrm{Na}$ GC, classes gramaticais como verbo e substantivo são definidas semanticamente, assim, um verbo, em contraste com um substantivo, é definido como aquele que perfila uma relação. $\mathrm{O}$ participante focal primário, o mais saliente e sobre o qual se fala ou descreve, é chamado de trajetor. O participante focal secundário, quando presente, é chamado de marco.

Assim como classes gramaticais como verbo e substantivo são definidas na GC conceitualmente, noções como sujeito e objeto também recebem uma caracterização conceitual, diferindo substancialmente da visão formalista, em que ambas as noções gramaticais são definidas sintaticamente. $\mathrm{Na}$ GC, sujeito e objeto são definidos em termos de proeminência, sujeito corresponderia ao nominal que codifica o foco primário

\footnotetext{
${ }^{8}$ Quando estivermos fazendo referência a operações de construal utilizaremos o verbo 'construir' (no original construe) em itálico.

${ }^{9}$ A base conceitual de um verbo, por exemplo, pode se manter constante em seus diferentes usos, havendo diferença em qual porção daquela base conceitual é perfilada e quais participantes recebem mais ou menos proeminência.
} 
(trajetor) em uma relação perfilada por um verbo, enquanto o objeto corresponderia ao nominal que codifica o foco secundário (marco).

Um ponto importante é que a assimetria de trajetor e marco é uma instanciação linguística do alinhamento de figura e fundo, não constituindo uma relação intrínseca na situação descrita, pelo contrário, essa assimetria diz respeito ao construal de uma cena. Assim, das entidades que participam em uma relação perfilada, nem todas necessariamente serão, ou poderão, ser focalizadas. Dessas que serão, uma será escolhida como figura com base no background fornecido pelos outros elementos. Por essa perspectiva, o marco age como ponto de referência em relação ao qual o trajetor é localizado ou interpretado.

E como Langacker (2008) salienta, proeminência, tanto em relação a alinhamento de trajetor e marco quanto profiling, é uma questão de como o falante decide descrever uma situação e não algo que pode ser objetivamente discernível naquela situação, ou seja, por ser um fenômeno conceitual, proeminência reside na forma como apreendemos e apresentamos o mundo e não no próprio mundo de forma objetiva.

Dessa maneira, comportamentos gramaticais usualmente associados a sujeito e objeto não são usados para definir essas noções, mas sim são tomados como sintomáticos de seu importe conceitual, i.e., de sua maior proeminência como participantes focados.

Nas palavras de Langacker (2008, p. 98), maior proeminência conceitual tem como consequência maior acessibilidade gramatical:

It stands to reason that the conceptual prominence would translate into grammatical "accessibility". The special grammatical behaviors of subject and object can thus be seen as symptoms of their referents being focused relational participants.

Dessa forma, comportamentos gramaticais, como concordância, surgem como forma de explorar ou sinalizar a saliência de certos participantes (LANGACKER, 2008).

Recentemente, Tomlin \& Myachykov (2015) reviram estudos que apontariam para uma relação entre atenção e a organização sintática no discurso, e que vão na 
mesma direção da caracterização de construal exposta acima. Os estudos revistos pelos autores indicavam que os falantes alternam entre estruturas sintáticas diferentes (como passiva e ativa) de acordo com o foco de atenção dirigido a referentes distintos do evento (como paciente ou agente).

Em inglês, por exemplo, os participantes aos quais a atenção era direcionada eram mapeados em relações sintáticas proeminentes (como sujeito). ${ }^{10}$ Assim, a probabilidade, de acordo com experimentos realizados, era de se usar construções como a passiva ou ativa a depender do participante focado, se o paciente ou agente, respectivamente. Já em outras línguas, como o russo (e também finlandês) que tem uma ordem de palavras mais livre e em que a passiva não é frequentemente usada, outras formas de se focar o paciente eram usadas, como topicalização. ${ }^{11}$

No entanto, como os autores observam, os mecanismos pelos quais as diferentes línguas fazem esse mapeamento, entre atenção e sintaxe, ainda é incerto. Já que a gramática das línguas possibilita aos falantes meios diferentes de se codificar gramaticalmente propriedades perceptuais do mundo (TOMLIN \& MYACHYKOV, 2015).

De todo modo, Tomlin \& Myachykov (2015) notam que parece haver, a princípio, uma certa universalidade no mapeamento entre o foco de atenção e a escolha sintática de sujeito na medida em que os falantes tentam mapear o referente mais saliente na posição de sujeito quando essa opção está presente.

Ainda assim, para os autores, a escolha sintática de sujeito não seria resultado apenas das características de saliência do evento descrito, sendo produto de várias forças que interagem. ${ }^{12}$ Os autores, por exemplo, discutem outros fatores como exposição recente à palavra designando o referente e também uma tendência a repetir configurações sintáticas que já foram encontradas ou produzidas. ${ }^{13}$

\footnotetext{
${ }^{10}$ No caso do inglês, a primeira posição da sentença, o ponto inicial da sentença, se correlaciona com a posição associada com o sujeito, em outras línguas, como o malgaxe, o referente focado, em testes similares feitos, era mapeado na posição de sujeito final da sentença.

${ }^{11}$ Resultados similares também foram obtidos de testes utilizando outras estruturas, como as sentenças locativas no inglês, em que o referente focado era realizado primeiro e em relação ao local, por exemplo, 'a star left of a heart' quando star era o referente focado.

12 Como já enfatizamos anteriormente, construal, ou a escolha da forma como construir uma determinada situação, é intrinsicamente ligada ao contexto interativo e comunicativo. Croft (1994) observa, aliás, que a semântica cognitiva e as abordagens funcionalistas investigam dois lados da mesma 'moeda'.

${ }^{13}$ É interessante notar que em teorias funcionalistas (como Chafe (1994) e Givón (1992), cf. nota 1), assim como na GC, assume-se que um participante no discurso seria escolhido como aquele mais proeminente, normalmente o sujeito (e, por vezes, o primeiro elemento na ordem de palavras). $\mathrm{O}$ foco
} 
De acordo com Tomlin \& Myachykov (2015), haveria ainda uma hierarquia nos mecanismos de mapeamento. Relações sintáticas de proeminência, como de sujeito, seriam mais automáticas e preferidas do que mecanismos como topicalização, este último estando ligado a medições mais lentas de produção sentencial e movimentos visuais.

Dessa forma, segundo os autores, mecanismos como topicalização seriam uma opção secundária em relação a posições sintáticas proeminentes como a de sujeito.

Naturalmente, mais estudos como esses são necessários não somente focando outras línguas, mas também utilizando outras construções, para que se possa formar um quadro mais completo de como o foco de atenção é codificado pelas línguas, revelando o que varia e o que seria, de fato, universal.

De qualquer forma, estudos como esse apontam fortemente para uma relação entre saliência conceitual e relações como de sujeito (o foco primário na GC). E acreditamos que, como já mencionamos, as línguas, sua estrutura, padrões e variação podem nos dar indícios desses processos e de como são codificados pela língua.

Como mencionado anteriormente, o significado de uma expressão, na GC, não equivale a conceitos, mas sim à conceitualização, termo que procura transmitir o caráter dinâmico desse tipo de processo (LANGACKER, 2008). Dessa forma, o significado de uma expressão engloba como o falante entende aquela expressão, tanto como falante, quanto como ouvinte, além de abarcar qualquer aspecto explorado para a construção daquele significado, como experiências e conhecimento prévios, contexto social, físico, cultural etc.

Assim, o processo de construção conceitual, servindo-se de fontes variadas e de um extensivo substrato conceitual, é altamente elaborado e rico, sendo apenas acionado por itens lexicais e padrões composicionais, i.e., a língua apenas disponibiliza instruções ou estímulos para a construção de elaboradas conceitualizações as quais somos capazes de realizar (EVANS \& GREEN, 2006; LANGACKER, 2008).

A partir disso, pressupõe-se que o significado das expressões não é objetivamente discernível nos eventos ou no mundo, o falante ou sujeito da conceitualização pode apreender situações e o mundo de diferentes modos, descrevendo-os de formas distintas. Essa liberdade não só implica uma escolha por 
parte do falante, mas também faz do significado de uma expressão algo dependente de seu ponto de vista e percepção para ser construído.

Diferenças estruturais, portanto, servem como indício, e reflexo, de como os falantes, como sujeitos da conceitualização, atribuem significado, fazendo escolhas com base em seu ponto de vista e percepção daquele evento ou situação, das relações envolvidas e, consequentemente, do mundo. Por conseguinte, a estrutura da língua dá pistas de como o falante conceitualiza situações e eventos por meio dos recursos que a própria língua disponibiliza.

\subsubsection{Domínios (domain) e arquétipos conceituais}

Comentamos na seção anterior que, na GC, o significado linguístico abarca tanto um conteúdo conceitual quanto o construal desse conteúdo. Como a base de seu significado, i.e., de seu conteúdo conceitual, uma expressão evoca um conjunto de domínios (domain) cognitivos, sendo a própria seleção desses domínios um aspecto do construal imposto.

Uma expressão, assim, pode evocar múltiplos domínios, nem sempre, como salienta Langacker (2008), se podendo chegar a uma lista exaustiva desses domínios.

A noção de domínio envolve qualquer tipo de concepção ou esfera de experiência, domínios que não são redutíveis a noções mais fundamentais ou a outros domínios são chamados de básicos, tais como espaço, tempo, temperatura, odor, paladar, dentre outros.

Já os domínios que são redutíveis a outros são chamados de não básicos e abarcam qualquer tipo de conceitualização capaz de ser explorada semanticamente, sejam essas concepções sensoriais ou intelectuais, estáticas ou dinâmicas, fixas ou novas, simples ou complexas. Dessa forma, domínios não básicos variam em seu grau de complexidade, indo de conceitos mínimos como VERMELHO a concepções mais elaboradas, como a configuração de um corpo humano (LANGACKER, 2008).

Domínios variam também no grau de centralidade com que são evocados dentro da matriz complexa de domínios ativada por uma expressão, há domínios mais centrais na medida em que são sempre evocados quando a expressão é usada, já outros são mais periféricos, isto é, nem sempre são ativados, sua ativação dependendo de determinados 
contextos. Dessa forma, a probabilidade de certos domínios serem ativados em certa expressão depende do contexto e uso.

Parte também importante da estrutura conceitual são as noções de arquétipo (na GC) e esquema imagético nos trabalhos de Lakoff e Johnson.

Esquemas imagéticos, nesses trabalhos, correspondem a padrões dinâmicos recorrentes de interação perceptual e motora e que dão estrutura e coerência para nossa experiência (perceptual, motora, emocional, histórica, social e linguística) (HAMPE, 2005).

Como aponta Hampe (2005), esquemas imagéticos têm significado (experiencial e corporificado), sendo pré-conceituais na medida em que são aterrados em movimentos humanos recorrentes pelo espaço, em interações perceptuais e no modo como manipulamos objetos.

Esses padrões de atividade são abstraídos de nossa experiência corporal diária, sendo estruturas básicas e pré-conceptuais e que dão origem a concepções mais elaboradas e abstratas através de combinação e projeções metafóricas (LANGACKER, 2008).

Dessas noções fundamentais e básicas, e em substituição ao termo 'esquemas imagéticos', Langacker (2008) prefere distinguir três tipos: conceitos mínimos em domínios particulares de experiência tais como as noções de linha, curva, ângulo no domínio espacial, precedência no domínio temporal, sensações cinestésicas ao exercer força muscular, etc.; conceitos configuracionais abstratos, independentes de qualquer domínio de experiência particular, tais como contraste, limite, mudança, contiguidade, contato, inclusão, separação, proximidade, grupo, etc.; e arquétipos conceituais, conceitos aterrados experiencialmente, frequentes e fundamentais o suficiente em nossa vida diária que tendemos a evocá-los como âncoras para construir nosso mundo mental em toda sua riqueza e nível de abstração (LANGACKER, 2008; 2010).

Arquétipos abarcam noções fundamentais, sendo apreendidas como gestalts apesar de seu nível de complexidade, como um objeto físico, um objeto em um local, um objeto movendo-se pelo espaço, o corpo humano, o rosto humano, o todo e suas partes, um container físico e seu conteúdo, ver alguém, segurar alguma coisa, entregar alguma coisa a alguém, exercer força muscular para causar uma mudança desejada, etc.

\subsubsection{Cadeia de ação e modelo de evento canônico na GC}


$\mathrm{Na}$ GC, como mencionado anteriormente, classes gramaticais, como verbo e substantivo, são definidas conceitualmente, tanto a nível de protótipo quando a nível de uma caracterização esquemática comum, estendida a todos os membros da categoria.

Para o verbo, o protótipo da categoria - um arquétipo conceitual aterrado em nossa experiência e suficientemente saliente para induzir que uma classe gramatical forme-se ao seu redor - seria a concepção de participantes interagindo energeticamente em um evento de dinâmica de forças (LANGACKER, 2008).

O termo 'dinâmica de forças' vem do trabalho fundacional de Talmy (1988) e se refere a como entidades são concebidas em relação ao uso da força, além de resistência à força, remoção de obstáculos, etc., esse uso da força estando ligado a uma base experiencial, como a experiência física de esforço muscular e movimento, além de sensações físicas como dor e pressão. ${ }^{14}$ Dinâmica de forças, no modelo do autor, constitui uma generalização do conceito de causa, analisando não só causa em termos de padrões de força, mas também conceitos relacionados como aqueles envolvendo noções de 'permitir', 'dificultar', 'ajudar'.

Quanto à caracterização esquemática, envolveria habilidades cognitivas básicas manifestadas, de início, no arquétipo conceitual e depois estendidas a outros membros, sendo válida para todas as instâncias. Para o verbo, essas habilidades seriam nossa capacidade de apreender relações e rastrear essas relações ao longo do tempo.

Tanto o arquétipo conceitual do verbo quanto do substantivo - a concepção de um objeto físico - fazem parte do que na GC chama-se de modelo da bola de bilhar, envolvendo a concepção de objetos discretos movimentando-se e interagindo uns com os outros energeticamente. Uma série dessas interações, havendo em cada uma transmissão de energia de um participante a outro, é chamada de cadeia de ação.

Esses arquétipos estão envolvidos no 'modelo de evento canônico', representando a forma mais canônica de ocorrência, i.e., um evento energético em que

\footnotetext{
${ }^{14}$ No estudo de Talmy (1988), são usados os termos agonista e antagonista para se referir às entidades em um evento de dinâmica de forças. O primeiro é aquele que recebe atenção focal e o segundo é aquele que se opõe ao agonista de forma a superar ou não sua força. Por exemplo, um evento como 'A bola estava rolando na grama' é neutro em relação à dinâmica de forças, enquanto um evento como 'A bola continuava rolando na grama' mostra padrões de dinâmica de forças distintos: em que ou a bola tem uma tendência ao repouso que é superada por alguma força externa, como o vento; ou a bola tem uma tendência ao movimento que está de fato superando uma força externa, como a dureza da grama. Observe que a dinâmica de forças não somente se aplica ao domínio de entidades físicas, mas também a domínios mais abstratos como modais (cf. Talmy, 1988).
} 
um agente age sobre um paciente para induzir uma mudança de estado (uma cadeia de ação envolvendo transmissão de energia de um participante a outro). Nesse modelo (o chamado stage model), o evento é concebido como se observado de um ponto de vista externo (off-stage) por um observador, sendo esse evento, colocado on-stage, o foco de atenção.

A forma mais típica de se codificar linguisticamente esse tipo de evento canônico é através de uma construção transitiva, em que a interação entre agente e paciente é perfilada e colocada on-stage, o agente constituindo o foco primário e o paciente o foco secundário. Nesse tipo de codificação default, os elementos da sentença adquirem seus valores prototípicos, i.e., um verbo prototípico é aquele que perfila uma interação entre agente e paciente, e o protótipo para o sujeito e o objeto são os arquétipos de agente e paciente respectivamente (LANGACKER, 2008).

Dessa forma, o protótipo de uma construção transitiva é o modelo de evento canônico. Transitividade, portanto, é uma noção conceitual, dependente de como a situação é construída, e uma questão de gradação, quanto maior o grau de aproximação de uma interação canônica entre agente e paciente, mais transitiva aquela construção, a princípio, será.

Essa visão de transitividade se alinha com a visão de transitividade presente em Hopper \& Thompson (1980). Para além da caracterização tradicional, que mede transitividade em termos somente de valência, isto é, do número de argumentos presentes na estrutural argumental do verbo, Hopper \& Thompson (1980) vão oferecer uma caracterização semântica de transitividade.

Nessa perspectiva, a transitividade de uma construção não pode ser medida de forma categórica a partir do número de argumentos do verbo isoladamente, pelo contrário, a noção de transitividade vai ser uma propriedade que engloba toda a sentença. Isso acarreta que a transitividade vai ser uma noção gradiente, calculada a partir de parâmetros. Consequentemente, as construções em uma língua podem ser mais ou menos transitivas.

Dessa maneira, o número de participantes em um evento seria apenas um dos parâmetros considerados para se medir a transitividade da sentença, havendo outros parâmetros como aspecto (télico ou atélico), pontualidade, volicionalidade, afirmação (se afirmativa ou negativa), modo (realis ou irrealis), agentividade e afetação e individuação do objeto. 
Por exemplo, 'João chutou a bola' é uma instância de construção com transitividade elevada, codificando um evento em que há transferência de energia entre agente e paciente, sendo um evento pontual, télico, volitivo, agentivo, afirmativo, realis, etc.

A construção transitiva (codificando o modelo de evento canônico), no entanto, não é a única estratégia de codificação presente nas línguas, nem a mais canônica a depender da língua. Langacker (2008) divisa, em particular, duas importantes orientações ou alinhamentos: orientação de agente e orientação de tema. Cada um desses alinhamentos reflete uma forma de dar proeminência linguística a um papel arquetípico de participante, nesses casos, de agente e tema (este último, abarcando, no uso do autor, os papéis de paciente, experienciador, zero, etc.). ${ }^{15}$

Embora cada língua, de uma forma ou de outra, faça uso de ambos os alinhamentos em menor ou maior grau, tanto um alinhamento quanto o outro pode ser estabelecido em dada língua como a orientação default ou mais canônica (LANGACKER, 2008).

A orientação de agente é a estratégia de codificação que seleciona o agente como trajetor, i.e., como foco primário. Segundo o autor, essa estratégia reflete um aspecto básico da experiência humana em que agimos no mundo como criaturas conscientes e volitivas, transmitindo energia para mantermos e controlarmos o ambiente ao redor. Nas línguas em que é selecionada como alinhamento default, o tipo mais básico de construção é a transitiva que codifica a situação descrita há pouco, i.e., uma interação canônica entre agente e paciente, em que o agente é escolhido como trajetor.

A orientação de tema, por sua vez, é a estratégia que seleciona o tema como trajetor. Assim como a orientação de agente, a orientação de tema também reflete um aspecto fundamental de nossa experiência, em que o mundo no qual operamos é posto de certa forma e onde entidades ocupam diferentes lugares e exibem propriedades distintas, sendo acessíveis e suscetíveis à nossa influência em diferentes graus (LANGACKER, 2008).

Nas línguas em que essa orientação é a default, o tipo mais básico de sentença é um processo temático envolvendo um único participante, o tema e, portanto, trajetor. Como nesse tipo de língua o tema recebe maior proeminência, em uma construção com

\footnotetext{
15 O papel de zero, para Langacker (2008), se refere a participantes que têm um papel conceitualmente mínimo ou não distintivo, apenas existindo, possuindo uma propriedade estática ou ocupando um local.
} 
dois participantes transitiva, é o tema que é o participante escolhido como trajetor (LANGACKER, 2008).

Um processo temático é aquele contendo apenas um participante, nesse caso, um tema, construído como passivo e não como fonte de energia (como o agente em uma cadeia de ação). Esse tipo de processo é construído de forma autônoma, sem evocar a fonte de energia, representando nessa concepção o que se chama, na GC, de construal absoluto. Segundo o autor, enquanto um processo temático pode ser concebido de forma autônoma, i.e., sem evocar a fonte de energia, o contrário não ocorre, já que não se poderia conceitualizar um evento agentivo sem evocar, ainda que esquematicamente, a ocorrência por ele induzida; a noção de agência, em si, pressupõe a existência de um processo temático (LANGACKER, 2008).

Essas duas orientações, na GC, refletiriam dois caminhos naturais de acesso mental aos elementos de um evento complexo, um em que o ponto de início seria o agente no fluxo de energia de uma cadeia de ação, e o segundo, em que o ponto de início seria o processo temático, i.e., em um processo construído de forma autônoma. Esses dois caminhos naturais ainda podem se alinhar com outros dois caminhos naturais, o de ordem de palavras e o de proeminência focal, i.e., partindo do trajetor, em seguida o marco e depois outros participantes. Cada uma dessas orientações, portanto, serviria como uma forma de alinhamento entre o ponto inicial do caminho natural de proeminência focal, o trajetor, e o ponto inicial de acesso mental de cada orientação; no caso do fluxo de energia, o agente; e no caso de um processo construído de forma autônoma, o processo temático.

\subsubsection{Metáfora conceitual na Linguística Cognitiva}

Esta seção busca salientar o papel importante e fundamental que a noção de metáfora conceitual adquiriu na Linguística Cognitiva através, inicialmente, dos trabalhos de Lakoff e Johnson, comentados a seguir. Essa discussão visa a destacar a concepção que permeia a Linguística Cognitiva e seus trabalhos de que a metáfora jaz em nosso sistema conceitual, ou seja, de que pensamos de forma metafórica, indo para além de um fenômeno antes confinado à manifestação linguística, mas que, como fenômeno conceitual, é refletido na língua e em sua organização. 
Também nesta seção, discutiremos o trabalho de Kövecses (2005) sobre metáforas no domínio da emoção em particular, seu estudo será importante para a análise delineada no capítulo 7 das construções dativas experienciais.

Tradicionalmente, nos estudos gramaticais clássicos, a metáfora e metonímia eram consideradas como figuras de linguagem, processos estilísticos próprios da linguagem literária. Um estudo fundador - advindo da corrente que posteriormente se denominou Linguística Cognitiva -, chamado de 'Metaphors We Live By' de Lakoff e Johnson (1980) veio a dar uma nova perspectiva sobre os estudos no campo. Em especial, tornou esses processos parte de nosso sistema conceitual. De acordo com os autores, nós pensaríamos de forma metafórica (e metonímica), i.e., nosso sistema conceitual seria metafórico e metonímico.

Dessa forma, a metáfora reflete um padrão de pensamento, sendo um mecanismo conceitual (EVANS \& GREEN, 2006). Isso significa dizer que nosso pensamento é metafórico e que entendemos o mundo através de metáforas.

O estudo fundador de Lakoff e Johnson (1980) traz uma série de fatos que mostram que nosso cotidiano, isto é, a forma como falamos, pensamos e agimos no dia a dia, é permeado de metáforas. Dessa forma, o fato de a linguagem ser repleta de metáforas - e isso não só no campo figurativo, mas também do ponto de vista gramatical - é um reflexo de nosso sistema conceitual de caráter metafórico.

E, se na LC, o significado linguístico equivale à conceitualização, um processo cognitivo, consequentemente, as próprias línguas, tanto sua semântica quanto sua estrutura, vão refletir e codificar esses processos metafóricos.

Por exemplo, os autores notam que concebemos noções abstratas como 'amor/relacionamento' como se fosse uma viagem ou jornada, isto é, em termos de um domínio mais concreto de nossa experiência no mundo. Algumas expressões em português que usamos corriqueiramente e que exemplificam essa metáfora são "Nosso relacionamento não está indo a lugar algum"; "É melhor seguirmos cada um o seu caminho.”; "Nós chegamos tão longe.”; "Tem sido um caminho difícil até aqui."

Outro exemplo de metáfora que corriqueiramente usamos é 'DISCUSSÃO É UMA GUERRA', observe as seguintes expressões do português: "Você não consegue defender seus argumentos"; "Você tem que manter sua posição"; "Ele o atacou com palavras duras"; “Ele acertou no alvo!”; "Eu nunca perco uma discussão!". Esses são apenas alguns exemplos de como nossa linguagem e pensamentos estão repletos de metáforas conceituais. 
Como definida por Lakoff \& Johnson (1980), metáfora é a apreensão de uma experiência através de outra. Isso significa que somos capazes de fazer associações entre diferentes domínios conceituais. Assim, a metáfora seria uma projeção entre diferentes domínios conceituais. Um seria o domínio fonte e outro seria o domínio alvo, um seria entendido, portanto, em termos do outro.

Nos exemplos que foram dados, 'viagem ou jornada' e 'guerra' seriam domínios fonte, constituindo o domínio concreto de nossa experiência; enquanto que 'amor' e 'discussão' seriam domínios alvo, mais abstratos e entendidos em termos do domínio fonte.

É importante notar que, para os autores, os mecanismos metafóricos não são arbitrários, eles são motivados por nossa experiência e interação com o mundo e cultura, tendo como base similaridades apreendidas.

Nos trabalhos fundacionais de Lakoff \& Johnson é enfatizado o aspecto experiencial das metáforas, i.e., metáforas são aterradas em nossa experiência corporal e física. Frequentemente, por exemplo, são encontradas nas línguas metáforas que associam de formas diferentes emoções (o domínio alvo) ao domínio físico da temperatura (domínio fonte): afeição como calor ('Ele foi muito caloroso'), indiferença emocional como frieza ('Ele foi tão frio'), etc. Uma das explicações para esse tipo recorrente de associação conceitual é justamente porque em nossa experiência corporal a interação com entes próximos presume contato mais íntimo e em troca de calor corporal, enquanto indiferença e distância implicam a falta desse contato e, portanto, ausência de calor (GRADY, 2007; KÖVECSES, 2005b).

Quanto à metonímia, é definida pelos autores como um deslocamento de significado, por exemplo, uma palavra ou expressão que era antes usada para designar uma coisa ou entidade passa a designar uma coisa ou entidade adjacente. Dessa forma, a metonímia difere da metáfora, pois envolve uma projeção em subdomínios de um mesmo domínio matriz, enquanto a metáfora envolve a projeção entre dois domínios diferentes.

Para ficar mais claro, quando dizemos que "Esse livro é muito bom" ou que "Esse prato é delicioso" não estamos querendo dizer que o livro (o material) ou o prato (o recipiente) são bons, mas sim que seu conteúdo é muito bom. Assim, estamos projetando um subdomínio sobre o domínio matriz que é LIVRO e PRATO, isto é, o fato de livros terem um conteúdo e o fato de pratos serem recipientes para alguma coisa faz disso um subdomínio de um domínio mais geral que é LIVRO e PRATO. 
Outro passo importante nos estudos de metáfora e metonímia, além da concepção desses processos como parte de nosso sistema conceitual, é o entendimento da relativa interdependência entre esses dois processos.

De acordo com estudos como o de Kövecses (2005b), em alguns processos metafóricos haveria uma motivação conceitual metonímica. Como exemplo, a metáfora “RAIVA É UM FLUIDO QUENTE EM UM CONTAINER" vista em expressões como "Ele quase explodiu de raiva", pode ser considerada como contendo diversos processos metonímicos ocorrendo em seu domínio fonte ou alvo, como a raiva sendo tomada por seus efeitos físicos como aumento de pressão e calor.

Como, no entanto, é apontado por Kövecses (2005b) e Geeraerts (2010), metáforas são também produtos culturais. Assim, tão importante como o estudo da base experiencial, aterrada em nosso corpo, de algumas metáforas, é o estudo de sua variação cultural e histórica.

Como exemplo dessa variação, Kövecses (2005b) cita casos de variação cultural nas metáforas usadas para entender o domínio abstrato de amor/relacionamento. ${ }^{16}$ Como citamos acima, em muitas culturas, como de língua inglesa, amor/relacionamento é concebido como JORNADA, em outras, como em alguns dialetos chineses, amor/relacionamento é concebido como SOLTAR UMA PIPA. Para Kövecses (2005b), diversas dimensões, experiencial, cultural e cognitiva, devem ser consideradas no estudo dos processos metafóricos.

Dessa forma, o estudo das metáforas, através de sua universalidade e de sua variação, é essencial para entendermos como conceitualizamos a realidade ao nosso redor e, consequentemente, nossas emoções através das línguas.

Como há de se notar, os processos metafóricos conceituais que permeiam a conceitualização do domínio da emoção serão fundamentais para nossa análise das construções dativas experienciais sob foco. Por essa razão, alguns pontos devem ser esclarecidos sobre o objetivo e resultado esperado de análise, especialmente sob o ponto de vista da universalidade de certos processos metafóricos na conceitualização das emoções e também em uma possível exclusividade desses processos ao domínio da emoção.

Embora acreditemos que há processos metafóricos conceituais que, espelhados por meio das construções sob foco, são comuns (no sentido de grande abrangência

16 Observe que o conceito de AMOR pode se aplicar, em alguns casos, tanto à emoção quanto a relacionamento. 
conceitual, aterrados experiencialmente) no modo como conceitualizamos o domínio das emoções nas línguas, não será defendida uma visão em que comum ou abrangente se equaliza a uma universalidade e exclusividade estrita, já que afirmar essa visão poderia incorrer no erro de pensar que o ser humano, independentemente de sua história e cultura, pensaria e conceberia suas emoções da mesma forma.

Um motivo é que não é difícil perceber que o domínio da emoção é complexo e há uma imensa variedade de expressões nas línguas e entre as línguas que codificam esse domínio.

Um aspecto a se notar é a diversidade das emoções humanas: nem todas as línguas vão ter expressões para o mesmo espectro de emoções, e mesmo quando há a identificação de emoções mais 'básicas' (tais como medo, raiva, amor, desejo, etc., aquelas normalmente encontradas na maior parte das línguas), há uma grande variedade na forma como essas emoções são concebidas e entendidas dentro de uma cultura.

Por essa razão, emoções não são somente aterradas experiencialmente em nosso corpo e interação com o meio ao redor, mas também em diferentes culturas e momentos históricos. Dessa forma, há de fato uma universalidade branda no sentido de que experiencialmente nossa conceitualização está aterrada em nosso corpo, gerando arquétipos conceituais que podem ser encontrados na conceitualização das emoções translinguisticamente, mas isso não é um fator limitante, i.e., esse fator experiencial não restringe nossa conceitualização da realidade de uma forma única (dizendo que emoções serão sempre conceitualizadas de determinada forma em todas as línguas), já que outros fatores estão intrinsicamente envolvidos em nossa visão de mundo como a cultura em que estamos inseridos.

Assim, na conceitualização de emoções, aspectos diferentes de nossa percepção experiencial e interação com o meio e cultura podem ser perfilados em detrimento de outros, gerando conceitualizações distintas de uma mesma emoção através das línguas.

Essas questões, da universalidade e exclusividade, foram estudadas por Kövecses (2005), que analisou extensamente em seus estudos as expressões emocionais nas línguas. Alguns aspectos de seu estudo serão trazidos neste momento para exemplificar de forma prática os pontos acima citados, mostrando o quanto são complexos dada a diversidade das emoções e da experiência humana e de sua conceitualização. 
Para exemplificar essa diversidade, tomemos alguns exemplos citados pelo autor em relação à raiva e amor, exemplificando processos metafóricos frequentes associados a essas emoções no inglês:

\begin{tabular}{|l|l|}
\hline ANGER 'raiva' & Metáfora conceitual \\
\hline $\begin{array}{l}\text { She is boiling with anger. } \\
\text { 'Ela está fervendo de raiva.' }\end{array}$ & $\begin{array}{l}\text { RAIVA É UM FLUIDO QUENTE EM } \\
\text { UM CONTAINER }\end{array}$ \\
\hline $\begin{array}{l}\text { I was struggling with my anger. } \\
\text { 'Eu estava lutando contra a minha } \\
\text { raiva.' }\end{array}$ & $\begin{array}{l}\text { RAIVA É UM OPONENTE EM UMA } \\
\text { LUTA }\end{array}$ \\
\hline $\begin{array}{l}\text { The man was insane with rage. } \\
\text { 'O homem estava louco de raiva.' }\end{array}$ & RAIVA É INSANIDADE \\
\hline $\begin{array}{l}\text { His actions were completely governed } \\
\text { by anger. } \\
\text { 'Suas ações eram completamente } \\
\text { dominadas pela raiva.' }\end{array}$ & RAIVA É UM SUPERIOR \\
\hline $\begin{array}{l}\text { He unleashed his anger. } \\
\text { 'Ele soltou sua raiva'. }\end{array}$ & RAIVA É UM ANIMAL CATIVO \\
\hline
\end{tabular}

Tabela 1: Metáforas de anger 'raiva' com base em Kövecses (2005).

\begin{tabular}{|l|ll|}
\hline LOVE 'amor' & Metáfora conceitual \\
\hline $\begin{array}{l}\text { There is a close tie between them. } \\
\text { 'Há um elo próximo entre eles.' }\end{array}$ & AMOR É UMA LIGAÇÃO \\
\hline $\begin{array}{l}\text { I am starved for love. } \\
\text { 'Eu estou faminto por amor.' }\end{array}$ & AMOR É UM NUTRIENTE & \\
\hline $\begin{array}{l}\text { She was overflowing with love. } \\
\text { 'Ela estava transbordando de amor.' }\end{array}$ & CONTAINER É UM FLUIDO EM UM & \\
\hline $\begin{array}{l}\text { I am burning with love. } \\
\text { 'Eu estou queimando de amor.' }\end{array}$ & AMOR É FOGO & \\
\hline $\begin{array}{l}\text { I was magnetically drawn to her. } \\
\text { 'Eu estava atraído por ela'. }\end{array}$ & AMOR É UMA FORÇA FÍSICA \\
\hline
\end{tabular}




\begin{tabular}{|l|l|}
$\begin{array}{l}\text { She tried to fight her feelings of love. } \\
\text { 'Ela tentou lutar contra seus } \\
\text { sentimentos de amor.' }\end{array}$ & AMOR É UM OPONENTE \\
\hline $\begin{array}{l}\text { I am crazy about you. } \\
\text { 'Eu estou louco por você.' }\end{array}$ & AMOR É INSANIDADE \\
\hline
\end{tabular}

Tabela 2: Metáforas de love ‘amor' com base em Kövecses (2005).

Processos metonímicos são também encontrados e muitas vezes constituem parte de processos metafóricos. Um processo metonímico frequentemente encontrado na concepção de emoções é tomar uma reação física pela própria emoção: 'Seu coração acelerou quando a viu', 'Suas mãos suavam ao vê-lo', 'Ele perdia o fôlego toda vez que se aproximava', 'Ela não conseguia tirar os olhos dele', etc.

Como Kövecses (2005) explica, a metonímia em muitos casos motiva a metáfora na medida em que uma resposta física ou comportamental de determinada emoção ou emoções é conceitualizada metaforicamente como a emoção.

Através dos exemplos dados acima é possível ver que mesmo dentro de uma mesma língua, há uma grande variedade na forma como diferentes emoções são concebidas e codificadas. Como o autor argumenta, no entanto, apesar dessa variação na forma como as emoções são conceitualizadas, há algumas equivalências, algumas sobreposições conceituais entre diferentes emoções. Por exemplo, algumas metáforas são encontradas tanto na conceitualização da raiva quanto do amor, como pode ser observado pelas tabelas acima, tais como emoção como insanidade ou como um oponente.

Kövecses (2005) vai observar que há, de fato, uma metáfora que seria mais geral na conceitualização das emoções e que seria instanciada por metáforas mais específicas, esse processo metafórico envolveria arquétipos conceituais, aterrados experiencialmente (os detalhes de sua análise, no entanto, serão expostos na seção 7.2). No momento, basta notar que a presença dessa metáfora atesta não uma universalidade estrita, no sentido de restringir a conceitualização de emoções (afirmando que as emoções nas línguas são conceitualizadas sempre através dessa metáfora mais geral), mas sim atesta a presença de aspectos experienciais que são suficientemente salientes para ocorrerem em um grande número de processos metafóricos utilizados para conceitualizar o mundo ao redor. 
Da mesma forma, aspectos salientes de nossa experiência que dão origem a certos caminhos metafóricos não podem ser considerados como exclusivos da conceitualização do domínio da emoção especificamente, já que os mecanismos cognitivos e conceituais são gerais e permeiam a nossa conceitualização de outros aspectos da realidade ao redor.

A pergunta que se pode fazer e que Kövecses (2005) faz é como pode haver variação na forma como conceitualizamos emoções se as metáforas são aterradas na mesma base experiencial humana que é universal? Para o autor, a resposta seria que essa variação seria decorrente de três motivações.

A primeira seria decorrente de diferentes framings (ou perfilações). $\mathrm{O}$ autor exemplifica com a concepção de desejo (sexual) no inglês através da metáfora DESEJO É CALOR, aparecendo em expressões como: 'She's burning with desire'; 'I've got the hots for her'; 'He's on fire for her'.

$\mathrm{O}$ autor nota, em contraste, que a língua chaaga, uma língua nígero-congolesa falada na Tanzânia, apesar de também conceitualizar o desejo através da metáfora DESEJO É CALOR, o faz de maneira diferente. Em expressões como nékeha 'ela queima' e nkeóka 'ela assa', as expressões não indicam que a mulher possui desejo, mas que ela tem qualidades ou atributos que são sexualmente desejáveis ao homem, tanto que a falta dessas qualidades é construída pela noção de frieza kyamúya rikó lilya 'Ela é fria' (cf. Kövecses (2005)). Dessa forma, diferentes aspectos do domínio fonte (envolvendo calor) são salientados nas duas línguas.

A segunda estaria relacionada à noção que o autor chama de foco experiencial, em que diferentes componentes ou aspectos de experiências aterradas universais podem receber menos ou mais atenção dependendo de um contexto cultural mais amplo.

Por exemplo, o autor aponta estudos que mostrariam que a noção de calor na concepção de raiva é muito mais prevalente em inglês do que o é em chinês, que se baseia mais na noção de pressão. Dessa forma, diferentes aspectos de nossa fisiologia são enfatizados na conceitualização de raiva nas duas línguas, nas palavras do autor: "The major point is that in many cases the universality of experiential basis does not necessarily lead to universally equivalent conceptualization" (KÖVECSES, 2005, p. $35)$.

A terceira, por fim, resultaria de um foco experiencial diferente ao longo do tempo, com isso, o autor procura apontar que a mudança ao longo do tempo também pode influenciar na forma como metáforas são usadas em uma dada língua. $\mathrm{O}$ autor traz 
um estudo que aponta que a conceitualização da raiva no inglês mudou consideravelmente do inglês antigo ao médio, havendo um aumento de palavras relacionadas a calor para descrever a raiva de um período ao outro, sendo que atualmente palavras relacionadas a calor compõem uma grande porção de expressões que são usadas para descrever a raiva.

Nas palavras do autor:

\begin{abstract}
If the conceptualization of anger in terms of heat is a mechanical or automatic consequence of our real physiology in anger, this fluctuation should not occur. It cannot be the case that people's physiology changes in anger every one or two hundred years or so. [...] universal physiology provides only a potential basis for metaphorical conceptualization-without mechanically constraining what the specific metaphors for anger will be.
\end{abstract}

Dessa forma, uma base experiencial comum tem o potencial de figurar de forma saliente em nossa conceitualização de um domínio abstrato como a emoção, no entanto, não é determinístico de sua concepção através das línguas e culturas ou mesmo em uma mesma língua. 


\section{VERBOS PSICOLÓGICOS: REVISÃO DA LITERATURA}

\subsection{Introdução}

O objetivo primeiro deste capítulo é apresentar estudos referenciais, de diferentes vertentes teóricas, sobre os chamados verbos psicológicos na literatura.

Veremos que o interesse pelos verbos psicológicos começou a partir da observação de propriedades que eram consideradas especiais desses verbos, como o fato de apresentarem realizações sintáticas distintas de seus argumentos e também processos sintáticos considerados peculiares, como o de backward binding. Autores largamente citados como Belletti \& Rizzi (1988), analisando essas características, fizeram uma distinção entre três classes de verbos psicológicos: temere, preoccupare e piacere.

É dessa distinção que se notam mapeamentos distintos de experienciadores e estímulos, respectivamente, experienciadores como sujeitos (SubjExp), experienciadores como objeto (ObjExp) e experienciadores marcados com o dativo (DatExp).

Dadas essas diferentes realizações, muitos trabalhos subsequentes tentaram explicar esse comportamento, apoiando-se em mecanismos sintáticos ou estruturas sintáticas distintas e procurando características que seriam definidoras de cada classe, seja por meio de papéis temáticos, traços semânticos ou estruturas de evento diferentes.

Resultados e insights importantes se originaram dessas análises, tais como a introdução da noção de causa como fator importante, a observação de características aspectuais influentes como estatividade e eventividade, etc.

A crítica feita, no entanto, é à divisão categórica feita por essas análises em que divisões e subdivisões (no caso de verbos ObjExp) são propostas com base nessas características e em mecanismos sintáticos que explicariam esse comportamento.

Nesse ponto, a análise de Grafmiller (2013) é trazida justamente para mostrar que muitos dos verbos considerados como pertencentes a uma ou outra classe ou subclasse, formam, na verdade, uma gradiência em termos de estatividade/eventividade e agentividade, sendo uma questão de como o evento é construído, e não de distinções binárias ou dicotômicas. 
Dessa forma, haveria tendências, conceitualizações mais prototípicas de certos eventos, o que não impede que esses eventos sejam construídos de forma diferente a depender do contexto e intenção do falante.

Veremos que essa perspectiva, adotada nesta tese e compatível com os preceitos da LC, visando não classificações categóricas, mas enfatizando o significado como ponto de partida e tomando como primordial o papel de operações de construal na conceitualização de eventos e sua diferente codificação nas línguas, possibilitará a observação de generalizações (e também de diferenças) importantes que, de outra forma, seriam perdidas se visássemos limites precisos e condições de pertencimento.

Acreditamos que um exemplo disso são as próprias construções dativas. Veremos ao longo da tese que essas construções não se encaixam nem no que chamam de construções SubjExp, nem em construções ObjExp, sendo que esse caráter híbrido é frequentemente deixado de lado a favor de adequar essas construções a um tipo ou outro.

Outras análises importantes que são trazidas são a de Dowty (1991) sobre os papéis de Proto-Agente e Proto-Paciente, em que experienciadores e estímulos teriam propriedades características de um cada um desses papéis (e por isso ambos seriam bons candidatos a serem sujeitos); e a de Croft (1993) sobre a bidirecionalidade de verbos experienciais (que, para ele, aplica-se somente a verbos experienciais estativos).

O estudo de Croft (1993) é interessante, pois lança uma diferente perspectiva sobre a conceitualização de eventos experienciais e a variação que apresentam tipologicamente. Embora apliquemos e ampliemos a noção de bidirecionalidade de forma diferenciada daquela pretendida pelo autor, seu estudo foi um ponto de partida importante para começarmos a olhar para a conceitualização dos eventos experienciais de forma mais aprofundada, abarcando não somente verbos experienciais marcados com o experienciador no caso dativo, mas também outras construções com verbos experienciais.

Apesar de que iremos discutir a noção de bidirecionalidade mais amplamente somente no capítulo 7, o presente capítulo introduzirá em seu final, preliminarmente, o conceito com dados de construções experienciais diversas de línguas como o português. 


\subsection{Revisão da literatura}

Os verbos psicológicos começaram inicialmente a despertar o interesse dos pesquisadores por um conjunto de características estruturais especiais que os distinguiam de outros predicados. Na década de 70, Postal $\left(1970,1971^{17}\right)$ já notava o comportamento distinto, em relação à ligação de anáforas, do que chamou de 'predicados psicológicos'. O exemplo a seguir ilustra, no português, esse tipo de fenômeno, chamado na literatura de 'backward binding' e notado, principalmente, em construções com o experienciador na posição de objeto:

(1) Comentários sobre si mesma 1 chatearam Maria1.

Exemplos como esse e de outras línguas violariam, na Teoria de Ligação, exigências de C-comando local, isto é, pelo menos na estrutura de superfície, a anáfora não estaria presa localmente ao seu antecedente.

Além desse tipo de comportamento, outra característica notável que chamou a atenção para os verbos psicológicos e representou um problema para teorias que procuravam explicar o mapeamento de estruturas lexicais a estruturas sintáticas foi a observação de que os argumentos de verbos psicológicos (experienciador e estímulo ${ }^{18}$ ) podem ser mapeados em diferentes posições sintáticas.

Belletti \& Rizzi (1988) (doravante B\&R), notando essa peculiaridade sintática e outros comportamentos, tais como o citado comportamento desses verbos em anáforas, observam que os verbos psicológicos em italiano podem apresentar três estruturas sintáticas:

Verbos com o experienciador na posição de sujeito e o estímulo na posição de objeto (a classe de temere):

\footnotetext{
${ }^{17}$ A distinção que será vista abaixo a respeito da diferença entre verbos com sujeitos experienciadores versus verbos com objetos experienciadores foi explicada por Postal (1971) através de transformações sintáticas chamadas de 'movimento psíquico', em que estruturas com experienciadores como objeto eram derivadas de estruturas profundas com sujeitos experienciadores através de movimento.

18 Usamos aqui o rótulo 'estímulo' seguindo Talmy (1985). Como ficará evidente nesta exposição, não há uma forma única na literatura, em construções com verbos psicológicos com dois argumentos, de se referir ao argumento que acompanha o argumento experienciador, sendo os rótulos mais comuns: 'estímulo', 'tema', 'causa', 'objeto da emoção', etc.
} 
(2) Gianni teme questo

Gianni teme isso. (B\&R, 1988)

Verbos com o experienciador na posição de objeto e o estímulo na posição de sujeito (a classe de preoccupare):

Questo preoccupa Gianni

Isso preocupa Gianni. (B\&R, 1988)

E verbos com o experienciador no dativo e o estímulo no nominativo (a classe de piacere) com duas possibilidades de ordem de palavras, o dativo na primeira posição ou última:

(4) A Gianni piace questo / Questo piace a Gianni Isso agrada a Gianni. (B\&R, 1988)

Enquanto os verbos psicológicos com sujeitos experienciadores não parecem representar um problema nas análises, sendo considerados como transitivos simples e recebendo por vezes pouca atenção da literatura linguística (ROZWADOWSKA, s/d), verbos psicológicos com experienciadores na posição de objeto e no dativo foram os que receberam a maior parte da atenção por seu comportamento sintático peculiar.

Em particular, esse tipo de variação no mapeamento desses verbos, quando considerados como tendo a mesma grade temática (experienciador e tema), é problemática para as teorias que propunham uma correspondência única entre papéis temáticos e posições sintáticas. ${ }^{19}$

B\&R (1988), assumindo uma versão relativizada dessa proposta (referida como RUTAH por Larson (1990) e Baker (1997), cf. nota de rodapé 19), vão propor uma análise em que as três classes vão ter a mesma grade temática [Experienciador, Tema], mas com especificações de grade de Caso distintas, sendo o mapeamento dessas grades em representações sintáticas regido por princípios que levariam em conta a proeminência temática, isto é, o experienciador seria projetado a uma posição mais alta do que o tema.

19 Por exemplo, a proposta formulada por Baker (1988) na gramática gerativa, Uniformity of Theta Assignment Hypothesis (UTAH), e a proposta de Perlmutter e Postal (1984) dentro da Gramática Relacional, Universal Assignment Hypothesis (UAH) (cf. Anagnostopoulou (2008), Croft (2012), Pesetsky (1995) e Rozwadowska (s/d)). 
Dessa forma, os autores tomam uma explicação essencialmente sintática de inacusatividade e movimento. Enquanto temere teria um experienciador que é um sujeito profundo, preoccupare e piacere vão ser considerados como tendo estruturas inacusativas na estrutura-D, i.e., o tema na posição de sujeito na estrutura-S seria um sujeito derivado, resultado de operações de movimento argumental.

A classe de temere, portanto, teria o experienciador como sujeito profundo em [Spec, S], sendo selecionado como argumento externo e não tendo especificações de Caso inerente. Por sua configuração ser a de um verbo transitivo simples, receberia caso nominativo (para o sujeito) e acusativo (para o objeto) estruturalmente.

Já as outras duas classes vão ter especificações de Caso inerente idiossincraticamente selecionadas para o argumento experienciador, assim, verbos da classe de preoccupare selecionariam Caso acusativo inerente, e a de piacere Caso inerente dativo. ${ }^{20}$

Levando em consideração a generalização de Burzio, é argumentado que os verbos dessas duas classes teriam estruturas-D inacusativas com dois objetos, como não teriam um argumento externo, não poderiam, consequentemente, atribuir Caso estrutural acusativo. Dessa maneira, o argumento tema é obrigado a se mover na estrutura para receber caso nominativo estrutural e o experienciador receberia Caso inerente, acusativo ou dativo, como argumento interno a VP. ${ }^{21}$

Para argumentar a favor da proposta delineada acima, B\&R (1988) discutem uma série de propriedades e processos sintáticos que explicariam o comportamento desses verbos e justificariam a análise inacusativa em que o sujeito de verbos da classe de preoccupare seriam sujeitos derivados e não profundos.

Por exemplo, os autores argumentam que o si anafórico só pode ser ligado a sujeitos profundos e não derivados (como em passivas e construções de alçamento), por essa razão (5) pode ter uma leitura reflexiva e (6) não:

\footnotetext{
${ }^{20}$ Seguindo a distinção de Chomsky de que há diferentes tipos de Caso, o Caso inerente seria aquele considerado como lexicalmente idiossincrático e relacionado à grade temática verbal, já Caso estrutural seria atribuído estruturalmente de acordo com regras de regência (B\&R, 1988).

${ }^{21}$ A respeito da possibilidade de os experienciadores no dativo poderem aparecer em diferentes posições, os autores dão a explicação de que, como a realização do dativo (ou acusativo) tem como requerimento estar sob o domínio de marca de Caso, seja do verbo ou de uma preposição, o experienciador dativo poderia se mover livremente, pois estaria sob a regência da preposição ' $a$ ' na estrutura-S. Ainda assim, mesmo com a possibilidade de o argumento dativo poder se mover, os autores notam que a ordem Exp V Tema, em que o experienciador está na primeira posição, parece ser a não marcada, i.e., a ordem mais natural.
} 
(6) *Gianni si preoccupa.

Gianni se preocupa (Gianni preocupa a si mesmo). (B\&R, 1988)

Os autores notam, no entanto, que (6) é gramatical se tiver uma leitura incoativa, no sentido de 'Gianni se preocupa em relação a alguma coisa não especificada'. Para eles, essa possibilidade tem a ver com a agentividade do argumento sujeito (um sujeito humano agindo volicionalmente de forma a induzir o evento psicológico no experienciador). Quando é possível uma leitura agentiva como em 'Os garotos assustam uns aos outros sempre que podem', o verbo psicológico passa a se comportar como um transitivo comum.

B\&R (1988) também vão discutir a propriedade de os verbos com o experienciador na posição de objeto de poderem ligar seu experienciador a uma anáfora na posição de sujeito (backward binding, citada acima). Para solucionar essa violação do Princípio A da teoria de ligação, os autores propõem que o Princípio pode ocorrer em qualquer lugar, seja na estrutura-D, seja na estrutura-S. Com isso, argumentam que o Princípio A nesses verbos seria atendido na estrutura-D em que o argumento experienciador está em uma posição mais alta que o tema e, dessa forma, o ccomandaria.

Tanto a explicação dada a essas propriedades sintáticas quanto a hipótese inacusativa de verbos psicológicos proposta por B\&R (1988) repercutiram de diferentes formas na literatura, assim como houve aqueles que criticaram certos aspectos da hipótese inacusativa, houve também aqueles que a adotaram, modificando-a ou melhorando-a.

Grimshaw (1990) critica esse tipo de análise que reduz a diferença entre a classe de temere e preoccupare a uma seleção lexical puramente arbitrária. Para a autora, a análise conduzida por B\&R (1988) perde uma dimensão fundamental que diferencia essas duas classes, a dimensão aspectual.

Dessa forma, a autora irá propor uma análise dessas duas classes (referidas, a partir do inglês, como a classe de fear e a classe de frighten) que leva em conta duas dimensões, a temática e a aspectual. 
Para a autora, a diferença crucial entre essas duas classes, e que vai ser amplamente explorada pela literatura, é a distinção aspectual entre estados e causas. Verbos da classe de fear seriam estativos, enquanto verbos da classe de frighten seriam causativos (teriam uma leitura eventiva e não agentiva). ${ }^{22}$

Como B\&R (1988), a autora assume que as duas classes de verbos psicológicos possuem grades temáticas idênticas (tema e experienciador). As relações temáticas vão ser organizadas de acordo com relações de proeminência, sendo o papel de Agente o mais proeminente seguido diretamente pelo Experienciador. ${ }^{23}$

A dimensão aspectual teria a noção de Causa, uma propriedade aspectual e não temática, como a mais proeminente.

Com base nisso, a seleção do argumento externo se dá a partir do elemento mais proeminente nas duas hierarquias. Um verbo transitivo como break possui um argumento externo que é ao mesmo tempo Agente e Causa e é mapeado à posição de sujeito, já a classe de frighten não vai apresentar um argumento externo devido ao seu argumento não ser o mais proeminente em ambas as hierarquias, causando conflito. Ainda assim, o argumento Causa vai ser necessariamente mapeado à posição de sujeito, pois vai ser a dimensão aspectual que vai definir qual argumento é selecionado como sujeito.

Assim como Belletti e Rizzi (1988), Grimshaw (1990) vai usar como evidência alguns processos sintáticos, como passivas e nominalizações, para argumentar a respeito das diferenças que propõe existir entre as duas classes. Por exemplo, tal como proposto por B\&R (1988), a autora mostra que verbos da classe de frighten, diferentemente de verbos da classe de fear, não podem ocorrer com passivas por não terem um argumento externo. Segundo a autora, somente poderiam aparecer com passivas adjetivais.

Grimshaw (1990) também vai argumentar que nem todos os verbos da classe de frighten vão ter o mesmo comportamento. Segundo a autora, as características peculiares dessa classe só vão ocorrer em contextos não agentivos. Em contextos agentivos, esses verbos seriam tratados como verbos transitivos típicos. Essa distinção é importante, já que vai figurar em muitas análises subsequentes dos verbos ObjExp, como veremos mais à frente.

\footnotetext{
${ }^{22}$ Segundo a autora, verbos SubjExp seriam eventos estativos simples, enquanto verbos ObjExp seriam eventos complexos na medida em que teriam dois subeventos, um causando o outro.

${ }^{23}$ A hierarquia temática proposta por Grimshaw (1990) é a seguinte: Agente > Experienciador > Alvo/Fonte/Local > Tema.
} 
A análise de Grimshaw (1990) dos verbos psicológicos, no entanto, não é incontroversa. Pesetsky (1995) vai criticar tanto alguns aspectos da análise de B\&R (1988) quanto de Grimshaw (1990). A começar pela análise de processos sintáticos como passividade, ligação de anáforas e interpretação arbitrária de pro como evidências para uma hipótese inacusativa dos verbos psicológicos.

De acordo com o autor, uma análise inacusativa não pode ser aplicada a todos os verbos ObjExp, i.e., apenas uma parte poderia ser considerada como 'puramente' inacusativa, outra parte não teria o mesmo comportamento (alguns dos testes propostos não constituindo evidência para sua inacusatividade). Em vista disso, para solucionar os problemas de mapeamento originados por esses verbos, o autor propõe uma análise semântica mais fina dos papéis temáticos.

O autor vai propor (proposta, aliás, já advogada em Pesetsky (1987, p.136)) que o papel de Tema normalmente atribuído ao estímulo de verbos psicológicos pode ser distinguido e subdividido em dois papéis: Causa e Objeto da Emoção (Target/Subject Matter of Emotion no original, daqui para frente citado como T/SM, e separado quando necessário). ${ }^{24}$

Enquanto o sujeito de verbos ObjExp sempre teria o papel de Causa, o objeto de verbos SubjExp sempre teria o papel de T/SM. Para ilustrar a diferença, observe os exemplos fornecidos pelo autor (p.56 e 57):

(7) a. Bill was very angry at the article in the Times. [Target of Emotion]

b. John worried about the television set. [Subject Matter of Emotion]

(8) a. The article in the Times angered/enraged Bill. [Causa]

b. $\quad$ The television set worried John. [Causa]

Na visão do autor, o papel temático de Causa é atribuído sempre ao sujeito, enquanto o papel de T/SM sempre à posição de objeto. Com essa distinção de papéis temáticos, Pesetsky (1995) resolveria o problema ocasionado por esses verbos quanto à

\footnotetext{
${ }^{24}$ Segundo o autor, a diferença entre Target e Subject Matter é que no primeiro o argumento alvo é avaliado pelo experienciador de acordo com a semântica do verbo, já o segundo não implica necessariamente uma avaliação por parte do experienciador, representando o assunto/razão da emoção. Inclusive, os dois tipos podem aparecer na mesma sentença como em 'Sue is angry with Bill about the party' (PESETSKY, 1995, p.63).
} 
exigência de correspondência única entre o mapeamento de papéis temáticos a estruturas sintáticas (cf. nota 19 sobre U(T)AH), ou seja, verbos ObjExp e SubjExp teriam duas grades temáticas distintas, cada um, portanto, mapeando seus argumentos de forma diferente.

Verbos ObjExp seriam, portanto, causativos, sendo morfologicamente complexos na medida em que teriam em sua estrutura um morfema zero causativo (CAUS). Já os verbos da classe de piacere de B\&R (1988), Pesetsky argumenta que a tradução correta no inglês seria appeal to e não please (que seria causativo). Para o autor, esses verbos (como appeal to) seriam inacusativos, o verbo não conseguiria atribuir caso ao T/SM que teria de alçar à posição de sujeito para ganhar caso, ao contrário do que acontece com verbos da classe de fear, em que o experienciador é alçado à posição de sujeito, enquanto o T/SM recebe caso internamente ao VP.

No entanto, uma das críticas feitas (cf. GRIMSHAW, 1990) à separação de Pesetsky (1987 e 1995) entre os papéis de Causa e T/SM é a chamada restrição T/SM em que Causa e T/SM não poderiam ocorrer na mesma sentença com verbos ObjExp (observe as sentenças em (9)). Reconhecendo esse problema, Pesetsky (1995) procura uma explicação em termos sintáticos, em que a restrição ocorreria por esses verbos serem morfologicamente complexos e conterem em sua estrutura um morfema zero (CAUS).

(9) a. * The article in the Times angered Bill at the government.

b. $\quad *$ The television set worried John about the veracity of Bill's alibi.

(PESETSKY, 1995, p.60)

Apesar das críticas, tanto a abordagem de Grimshaw (1990) quanto a de Pesetsky (1995) trouxeram a noção de Causa, ainda que de formas diferentes, como importante fator na diferenciação estrutural dos verbos psicológicos. ${ }^{25}$ Propriedade que

\footnotetext{
${ }^{25}$ Reinhart (2002), aliás, ao comentar sobre a proposta de Grimshaw (1990) que considera Causa como um papel aspectual, diz compartilhar a visão da autora de que o papel de Causa (em seu sistema, o traço [+/-c]) é um importante fator para determinar a natureza eventiva de certos predicados, como os verbos ObjExp.
} 
será também explorada por outros autores na forma de traços, por exemplo, Reinhart $(2002) \cdot{ }^{26}$

Reinhart (2002) adota dois diferentes traços binários ([+/- $c]$ causa-mudança) e ([+/- $m]$ estado mental). Para a autora, esses dois traços refletiriam duas propriedades básicas e cruciais na interpretação dos predicados verbais, causalidade externa e volicionalidade (ou alguma propriedade mental ou senciência). ${ }^{27}$ Combinados esses traços resultariam em nove conjuntos de traços distintos (referidos como clusters). Esse conjunto de traços teria o objetivo de captar os diferentes tipos de argumentos dos verbos, i.e., cada um teria uma codificação única de traços temáticos. ${ }^{28}$

Dessa forma, um conjunto de traços como $[+c+m]$ corresponderia ao agente, $[-\mathrm{c}+\mathrm{m}]$ ao experienciador, $[-\mathrm{c}-\mathrm{m}]$ ao paciente/tema, $[+\mathrm{c}]$ à causa, e assim por diante.

A noção de causa também vai ter um papel importante na definição da autora de alternâncias argumentais. Para ela, verbos inacusativos como 'break' em 'The window broke' vão ser todos obtidos através de derivação de seus correspondentes causativos $(H e[+\mathrm{c}]$ broke the window). Nesse caso, as propriedades de um verbo inacusativo vão ser definidas a partir de sua contraparte causativa. A autora ainda argumenta que há apenas algumas exceções em que não é possível encontrar em uma língua ou outra a variante causativa de um verbo inacusativo.

Verbos experienciadores intransitivos como 'worry' (de 'I worry (about John)') seriam também derivados por redução de uma contraparte transitiva $($ John $[+\mathrm{c}]$ worries Mary) e são considerados como inergativos pela autora. $\mathrm{O}$ argumento [+c] da versão transitiva é realizado externamente e o experienciador deve ser realizado internamente, possibilitando a checagem de caso acusativo. Quando o processo de redução ocorre, caso acusativo é suprimido e o experienciador deve ser realizado externamente, o argumento SM (subject matter) com o traço [-m], se presente, é realizado internamente. $^{29}$

\footnotetext{
${ }^{26}$ Ver também a abordagem de traços temáticos de Rozwadowska $(1988,1989,1992)$.

27 É interessante observar que a autora nota que causalidade não é considerada como uma relação lógica (como acarretamento), mas sim é uma relação imposta pela percepção humana do mundo (REINHART, 2002, p. 12). Assim, nas palavras de Rákosi (2006, p. 27) que estudou os verbos psicológicos no Húngaro a partir da teoria de traços temáticos de Reinhart (2002), 'causalidade teria um papel linguisticamente relevante e especial na cognição humana'.

${ }^{28} \mathrm{Na}$ abordagem lexicalista de Reinhart (2002), é a estrutura temática dos verbos que determina sua sintaxe.

${ }^{29}$ Como também argumentado por Pesetsky (1995), a sentença em 'The doctor worries Mary' não acarreta necessariamente que 'Mary worries about the doctor', i.e., Mary pode estar preocupada com sua própria saúde e não com o médico. Assim, a depender do contexto, na primeira sentença, o médico
} 
Reinhart (2002) nota ainda que os conjuntos de traços (clusters) são frequentemente interpretados pelo contexto, característica que, segundo a autora, compartilharia com a proposta de Dowty (1991). Ademais, a proposta de Dowty (1991) também se identifica com Reinhart (2002) ao elencar a noção de Causa como importante propriedade na seleção argumental.

Embora as propostas sejam diferentes, Rákosi (2006) aponta a proposta de Dowty (1991) como antecessora ao sistema de traços de Reinhart (2002), à medida que parte da ideia de decomposição de papéis temáticos tradicionais em uma lista de propriedades semânticas que teriam relevância gramatical para a seleção dos argumentos.

Dowty (1991) propõe decompor os tradicionais papéis temáticos discretos em uma lista não exaustiva de acarretamentos que caracterizariam o que chama de "protopapéis', a saber, Proto-Agente e Proto-Paciente. ${ }^{30}$

Por essa perspectiva, um argumento verbal poderia ser menos ou mais 'agente' ou 'paciente', a depender da quantidade de acarretamentos que compartilha com cada um.

Em relação aos verbos psicológicos como o par fear/frighten, Dowty (1991, p. 579) menciona que o comportamento especial desses verbos é devido aos seus argumentos terem características do papel de Proto-Agente. Enquanto o experienciador tem uma percepção do estímulo (i.e., tem o acarretamento de ser senciente, característica do Proto-Agente), o estímulo causa uma reação emocional ou cognitiva no experienciador (acarretamento de 'causar uma mudança', também característica do Proto-Agente).

Por essa razão, cada um desses argumentos, segundo o autor, teria igual direito a estar na posição de sujeito.

Dowty (1991) observa, no entanto, a partir de Croft (1986), que há uma característica no experienciador, em verbos ObjExp, que poderia fazer dele um melhor candidato à posição de objeto na seleção argumental. Segundo Dowty (1991), Croft (1986) notou que verbos SubjExp seriam sempre estativos, enquanto verbos ObjExp seriam ou incoativos ou estativos. Se incoativos, os verbos denotariam o surgimento da percepção e a consequente reação emocional ou cognitiva, dessa forma, haveria uma

é a causa, mas não necessariamente o objeto da emoção, enquanto na segunda, o médico é o objeto da emoção, mas não necessariamente a causa da preocupação.

30 É importante notar que Dowty (1991) não caracteriza sua proposta como uma 'decomposição de traços', pois as fronteiras entre os acarretamentos que propõe não seriam completamente delimitáveis. 
mudança de estado no experienciador que viria a experienciar aquela emoção ou estado mental. Para Dowty (1991), essa interpretação incoativa, designando a mudança de estado sofrida pelo experienciador, seria um possível indício de uma propriedade de Proto-Paciente do experienciador em verbos ObjExp.

Como notamos ao discutirmos a proposta de Grimshaw (1990) acima, as diferenças aspectuais entre as classes de verbos psicológicos foram consideradas por diversos autores como a razão das realizações sintáticas distintas observadas. No entanto, não há consenso na literatura em relação a quais seriam, de fato, as características aspectuais definidoras de cada classe, principalmente em relação aos verbos ObjExp (MARÍN, 2014).

Verbos SubjExp (como a classe de temere) e verbos com o experienciador no dativo (como piacere) normalmente são considerados como verbos estativos. Já verbos com ObjExp são frequentemente analisados na literatura como sendo ambíguos entre uma leitura agentiva, eventiva (causativa) e estativa (ROZWADOWSKA, s/d), sendo que, as propriedades especiais observadas nesses verbos, são usualmente atribuídas às leituras não agentivas (tornando a ausência de agentividade um fator importante).

Em razão de sua difícil caracterização, verbos ObjExp receberam diferentes análises quanto às suas propriedades aspectuais, dentre as mais recorrentes, causatividade (cf. ARAD, 1998; PYLKKÄNEN, 2000, etc.) e incoatividade (cf. ROZWADOWSKA, 2003, 2012; MARÍN \& MCNALLY, 2011, etc.). ${ }^{31}$

Tanto Arad (1998) quanto Pylkkänen (2000) argumentam que uma parte dos verbos ObjExp são estativos e causativos, i.e., causatividade não implicaria necessariamente dinamicidade.

Arad (1998) propõe que verbos ObjExp apresentam peculiaridades sintáticas apenas em sua leitura estativa. Para isso, a autora distingue três leituras possíveis que levariam em conta duas propriedades, a agentividade do argumento não experienciador e se há mudança de estado ou não.

Na leitura agentiva, há tanto um agente que age intencionalmente, quanto uma mudança de estado no experienciador (ARAD, 1998, p.3):

\footnotetext{
${ }^{31}$ Marín e McNally (2011) analisam os verbos psicológicos pronominais em espanhol (como preocuparse) como verbos incoativos que não seriam nem télicos, nem dinâmicos, subdividindo-os ainda em dois tipos, aqueles que seriam pontuais (enfadarse 'irritar-se') e não pontuais (preocuparse 'preocupar-se'). Para os autores, esses verbos não seriam télicos na medida em que apenas se referem ao início do evento e não à mudança que produz o estado. Já a não dinamicidade é devido ao primeiro grupo ser pontual e ao segundo por serem estados.
} 
(10) Nina frightened Laura deliberately / to make her go away.

Na leitura eventiva, há uma ação não intencional que causa uma mudança de estado no experienciador:

(11) a. Nina frightened Laura unintentionally / accidentally.

b. The explosion / noise / thunderstorm frightened Laura.

(ARAD, 1998, p.3)

Por fim, na leitura estativa, não há nem uma mudança de estado (entendida como a transição de um estado a outro, por exemplo, de 'não assustado' a 'assustado' nos casos acima), nem um agente. Envolve apenas a percepção do experienciador do estímulo que, portanto, aciona um determinado estado mental nesse experienciador, dessa forma, o estado emocional ou percepção do estímulo está fora de controle de ambos os participantes (ARAD, 1998, p. 3 e 4):

(12) a. John / John's haircut annoys Nina.

b. John / John's behaviour / nuclear war frightened Nina.

c. This problem concerned Nina.

Para a autora, nas leituras não estativas há uma causação ativa, em que uma mudança de estado ocorre - o estímulo apenas causa esse estado resultante que acontece independentemente dele, i.e., o estímulo não é parte do estado mental. Já na leitura estativa há uma causação estativa, pois é acionado um estado concomitante em que o estímulo é parte inerente do evento e que só se sustenta com ele. ${ }^{32}$

\footnotetext{
${ }^{32}$ Arad (1998) nota que enquanto alguns verbos, como frighten, permitem todas as leituras, há verbos, como worry e concern, que apenas permitiriam a leitura estativa. Em contrapartida, verbos como surprise seriam difíceis de se construir com uma leitura estativa. Pesetsky (1995), ao longo de seu trabalho, também vai observar que nem todos os verbos da classe de ObjExp são iguais nesse aspecto, verbos como startle, scare e surprise, por exemplo, favoreceriam uma leitura agentiva, frighten, embarass e amuse seriam neutros aspectualmente e verbos como concern, depress e worry seriam sempre estativos.
} 
Mais à frente, em Arad (1999), a autora vai propor que tanto a leitura causativoestativa quanto a agentiva vão apresentar um núcleo funcional $v$, diferindo apenas na natureza desse núcleo funcional, a primeira teria um $v$ causativo-estativo, e a segunda um $v$ agentivo. Apenas o $v$ causativo-estativo apresentaria as propriedades peculiares da classe de frighten.

Assim, a consequência sintática dessas diferentes leituras é que, enquanto os verbos de leitura estativa teriam todas as propriedades dos chamados verbos psicológicos, os verbos de leitura agentiva se comportariam como transitivos comuns.

Uma crítica feita por Landau (2010) - o qual veremos mais à frente - à análise de Arad $(1998,1999)$ é que não há uma explicação de por que um determinado núcleo funcional na língua teria determinadas propriedades e não outras.

A ideia de Grimshaw (1990) (cf. nota 22 acima) de que os verbos psicológicos teriam diferentes estruturas de eventos é também explorada por Bialy (2005) e por outras abordagens baseadas na estrutura de eventos ${ }^{33}$. Bialy (2005) faz uma distinção entre verbos ObjExp estativos e verbos ObjExp não estativos em termos de estrutura de eventos. Na mesma linha de Pylkkänen (2000) e Arad (1998), Bialy (2005, p. 160) considera os dois tipos como sendo causativos, propondo os seguintes esquemas de evento:
a. $\quad[e$ CAUSE $[\mathrm{BECOME}[\mathrm{y}<\mathrm{STATE}>]]]$
Não-estativo
b. $\quad[e$ CAUSE $[\mathrm{y}<\mathrm{STATE}>]]$
Estativo

Os verbos ObjExp não estativos vão diferir dos estativos na medida em que vão apresentar o operador incoativo BECOME refletindo a mudança de estado que não está presente nos verbos estativos (cf. Arad (1998) acima).

Como nota Grafmiller (2013, p.2), a ideia daqueles que visam, principalmente, explorar a interface entre semântica e sintaxe é identificar os aspectos semânticos que seriam relevantes para a estrutura gramatical. As entradas lexicais teriam o papel de conter as informações semânticas, sejam elas na forma de papéis temáticos, traços semânticos ou estruturas de evento que seriam indicativas de seu importe semântico individual e, consequentemente, da estrutura originada.

\footnotetext{
${ }^{33}$ Cf. Iwata (1995) e Didesidero (1999); e também Grafmiller (2013) e Carneiro (2011) para uma revisão desses trabalhos respectivamente.
} 
Ainda que as análises revistas até o momento explorem em diferentes graus aspectos semânticos na caracterização dos diferentes tipos de verbos psicológicos, a maior parte, de uma forma ou de outra, se apoia em mecanismos sintáticos ou estruturas sintáticas distintas para explicar seu comportamento.

Outra linha de pesquisa de base sintática, por exemplo, que frequentemente é utilizada para explicar o comportamento, em particular, de verbos com experienciadores dativos é a teoria dos núcleos aplicativos (cf. Pylkkänen (2008) e Cuervo (2003) para o espanhol). A hipótese central é a de que objetos indiretos não seriam argumentos lexicalmente diretos do verbo, mas seriam introduzidos por um núcleo aplicativo na posição de especificador (i.e, o argumento adicionado seria projetado para a sintaxe não pelo verbo, mas por um núcleo especializado). ${ }^{34}$

Dessa forma, seria o sintagma aplicativo, e não o verbo, o responsável por introduzir o argumento dativo tanto semântica quanto sintaticamente.

Esse núcleo aplicativo é projetado em diferentes estruturas sintáticas e teria diferentes interpretações (alvo, possuidor, experienciador, beneficiário, etc.) a depender da posição, i.e., o significado do dativo seria determinado pela posição sintática em que pode aparecer.

Considera-se que haveria dois tipos de aplicativos, os aplicativos altos que denotam uma relação entre o evento e argumento e os aplicativos baixos que denotam uma relação entre argumentos e são internos ao VP.

Cuervo (2003, p. 169) argumenta que o argumento experienciador em uma sentença como 'A Daniela le gustan los gatos' é um aplicativo alto introduzido em SpecAppIP, sendo um argumento externo à predicação (o verbo mais o DP nominativo que seria seu sujeito). Assim como na proposta de B\&R (1988), o argumento dativo é mais alto que o tema nominativo e o c-comandaria.

Outra abordagem sintática importante dos verbos psicológicos é a proposta de Landau (2010). A análise do autor é voltada à hipótese de que experienciadores na posição de objeto são sintaticamente locativos, i.e., indiferentemente de haver ou não razões conceituais para considerar experienciadores objetos como locativos mentais, o autor parte exclusivamente da premissa de que argumentos experienciadores são locativos sintáticos e por isso apresentam características especiais.

\footnotetext{
${ }^{34} \mathrm{O}$ termo aplicativo vem de línguas (como as línguas bantu e austronésias) em que a valência do verbo é aumentada ao se acrescentar um elemento aplicativo à estrutura verbal (normalmente um afixo) (cf. RICHARDSON, 2007).
} 
Dessa forma, ao longo de toda a tese, o autor vai se valer de testes e fenômenos sintáticos para mostrar que objeto-experienciadores são argumentos oblíquos translinguisticamente. A diferença é que em algumas línguas isso seria marcado por uma preposição ou caso oblíquo de fato e, em outras, por uma preposição nula. Em inglês, por exemplo, o caso atribuído a essa preposição nula, caso acusativo inerente, seria o mesmo atribuído a objetos diretos.

Assim como Grimshaw (1990) e Arad (1998, 1999), Landau (2010) também vai assumir que as propriedades que chama de centrais (core properties) dos verbos com objeto-experienciadores só acontecem em contextos não agentivos. Ademais, Landau (2010), seguindo Pesetsky (1995) e outros, vai considerar verbos de classe III (a classe de piacere) como verbos inacusativos, o argumento tema desses verbos seria T/SM e não causas. Verbos de classe II (classe de preoccupare) vão ter uma estrutura transitiva, projetando um núcleo leve $v$ e um argumento externo, a causa. Já o argumento experienciador seria introduzido pela preposição nula.

Voltando-nos para análises de verbos psicológicos no português, Cançado (1996) analisa um grande número de verbos considerados como psicológicos no português e chega a uma divisão de quatro classes com base em propriedades sintáticas como ergativização do verbo (A mãe se preocupa com a arrogância de Rosa), causa na posição de sujeito (A arrogância (Causa) de Rosa preocupava a mãe), inversão dos argumentos (José teme o tamanho do cachorro), passivização sintática (O cachorro é temido por José) ou adjetiva (A mãe ficou preocupada com Rosa), pro arbitrário (Temem o cachorro pelo seu tamanho) e causativas encabeçadas ( $\mathrm{O}$ amigo faz José temer o cachorro).

A primeira classe divisada pela autora é a dos verbos psicológicos conhecidos na literatura como SubjExp. Segundo Cançado (1996), esses verbos psicológicos não admitem construções ergativas e causativas (com a causa na posição de sujeito) e nem passivas adjetivais (apenas sintáticas).

As outras três classes são subdivisões da classe de verbos psicológicos conhecida como ObjExp. A Classe 2 da autora é a de verbos como preocupar que admite apenas ergativização, causatividade e passivas adjetivais. A Classe 3 , de verbos como acalmar, admite, diferentemente da Classe 2, passivas sintáticas (e não adjetivais), pro arbitrário e causativas encabeçadas. A Classe 4, como animar, admitiria as propriedades sintáticas tanto da Classe 2 quanto 3, a escolha, para a autora, vai depender da leitura agentiva ou não desses verbos. 
Segundo a autora, a diferença observada entre essas classes no português não é por diferenças a nível sintático (como o é na proposta inacusativa de B\&R (1988) vista), nem a nível aspectual (como na proposta sintático-aspectual de Grimshaw (1990)). Mas sim, é resultado de diferenças em termos de papéis temáticos e de uma hierarquia temática desses papéis, isto é, cada classe teria uma rede temática distinta que explicaria as realizações e propriedades sintáticas distintas dessas classes. A classificação temática das quatro classes proposta por Cançado (1996, p.107) seria a seguinte:
(14)
a. TEMER: $\{$ Exp, Obj $\} \quad$ Classe 1
b. PREOCUPAR: $\{\mathrm{Cau}, \mathrm{Exp}\}$
Classe 2
c. ACALMAR/ANIMAR: $\{$ CAUSA, Exp $\}$
Classe 3 / Classe 4

Ao contrário da Classe 2, as Classe 1, 3 e 4 teriam o traço [+controle] nos seus argumentos na posição de sujeito, o que explicaria o fato de essas classes aceitarem a passiva sintática e causativas encabeçadas e a Classe 2 não. A Classe 1, por não ter o argumento interno afetado (o papel Objetivo não acarretaria esse traço), não aceitaria ergativização e causativização. O papel CAUSA é um macropapel, significando que o verbo aceitaria tanto uma Causa, quanto um Agente ou Instrumento.

Em relação à propriedade de backward binding associada aos verbos psíquicos, a autora chega à conclusão de que essa não é exclusiva dos verbos psicológicos, ocorrendo também com outros predicados. ${ }^{35}$

Vimos até agora que o interesse pelos verbos psicológicos começou a partir de algumas propriedades especiais desses verbos, como o fato de apresentarem realizações sintáticas distintas de seus argumentos e também processos sintáticos considerados peculiares, como backward binding. Autores como B\&R (1988), observando essas características, fizeram uma distinção entre três classes, temere, preoccupare e piacere.

A primeira classe (a classe de fear no inglês e também chamada de verbos SubjExp), como na maior parte dos trabalhos revistos, é considerada como uma construção transitiva comum. A classe de preoccupare (no inglês, a classe de frighten,

\footnotetext{
${ }^{35}$ Cançado e Franchi (1999), analisando especificamente o fenômeno, mostram que backward binding não é uma propriedade só de verbos psíquicos, o que indicaria que essa propriedade não é devido a uma configuração sintática particular desses verbos. Landau (2010), revendo a literatura, também vai concluir que essa propriedade não atesta para uma característica sintática particular dos verbos psíquicos, o que o faz considerá-la como uma propriedade periférica desses verbos.
} 
também chamada de verbos ObjExp) foi a que mais chamou a atenção por ser considerada como uma classe heterogênea, com base em três fatores principais estudados pelos autores revistos acima, causatividade, agentividade e estatividade/eventividade. ${ }^{36}$ A classe de piacere (no inglês, a classe de please ou appeal to a depender do autor), usualmente não lhe era atribuída a heterogeneidade da classe anterior, sempre considerada pela maioria como estativa e não causativa.

Essa aparente ambiguidade e heterogeneidade distinguidas na classe de verbos ObjExp levou muitos estudiosos a fazerem uma distinção mais fina dessa classe, seja em termos de sua estrutura temática, sintática, de eventos ou em forma de traços semânticos. Dessa forma, a classe de ObjExp começou a ser subdividida de acordo com critérios como a agentividade do estímulo, causatividade e aspecto do evento que, na maior parte, são identificados a partir de testes, dentre eles, o uso de advérbios, passividade, etc.

De fato, o estudo dessas diferentes propriedades e leituras possíveis em verbos ObjExp é importante na descrição e entendimento da natureza dos eventos psicológicos codificados pelas línguas e em uso pelos falantes. Dessa forma, estudos como os vistos até o momento são referenciais e esclarecedores em muitos aspectos e, sem dúvida, nos dão base para muitos e profícuos questionamentos.

De todo modo, a primeira crítica e incômodo que se manifestam ao nos depararmos com essas análises é a divisão categorial em subclasses, de verbos ObjExp principalmente, com base em distinções dicotômicas de critérios como agentividade e estatividade. Questiona-se se essas divisões, de fato, refletem o uso dos falantes, já que grande parte desses estudos é feita a partir de exemplos e testes criados pelos próprios autores e julgados aceitáveis ou não a partir de sua própria percepção e não de um levantamento de corpus de língua em uso.

A segunda e que segue da primeira é o risco de se postular condições necessárias e suficientes para o agrupamento de verbos sem considerar o papel gradiente de algumas propriedades conceituais e de como podem estar envolvidas em operações de construal, i.e., em formas distintas de se construir eventos nas línguas.

Em terceiro lugar, alguns autores assumem através do comportamento sintático dos verbos psicológicos, principalmente aqueles ObjExp, que esses verbos são especiais

\footnotetext{
${ }^{36}$ Como foi visto, muitos autores argumentam que as propriedades especiais dos verbos psicológicos só ocorrem em sua leitura estativa/não-agentiva, mas não há consenso sobre qual dessas propriedades seria mais importante para a distinção entre os verbos Obj-Exp, se estatividade ou agentividade.
} 
sintaticamente e, por conseguinte, propõem estruturas ou mecanismos sintáticos (como movimento ou núcleos funcionais específicos) que os distinguem dos demais predicados psicológicos ou mesmo entre si. Alguns critérios usados, no entanto, para diferenciar verbos SubjExp de ObjExp e entre subclasses de verbos ObjExp como agentividade, causatividade e estatividade são nuances de significação que não implicam (ou resultam), necessariamente, em oposições estruturais ou mesmo temáticas categóricas entre verbos psicológicos, fazendo parte, na verdade, de um substrato conceitual mais complexo envolvido na variação observada entre construções ObjExp e SubjExp e também dativas.

Com isso, queremos dizer, primeiro, que é possível pensar nessas distintas significações como processos gradientes e resultado de formas diferentes de se conceitualizar eventos por parte dos falantes e, portanto, a diferença vista não é categórica e puramente estrutural. E, segundo, essas significações não são intrínsecas aos significados verbais ou aos eventos (como reflexo de um mundo objetivo) a ponto de esses verbos poderem ser classificados de forma única.

Em modelos baseados no uso, como a Linguística Cognitiva, as unidades linguísticas (sejam elas verbos ou construções complexas) consistem em abstrações de diferentes graus de eventos de uso, emergindo a partir do arraigamento de aspectos comuns selecionados e apreendidos e tornando-se rotinas cognitivas.

Como Langacker (2009b) discute, verbos são aprendidos no contexto das construções em que aparecem - não em isolamento - e vice-versa, e com o arraigamento e convencionalização do uso do verbo em determinada construção é que se pode dizer que o verbo tem o sentido associado àquela construção, em outras palavras, aquela construção, ou significado associado à construção, faz parte do network de construções, ou sentidos, associadas ao lexema verbal.

Assim, o significado e uso dos verbos são resultado de seu uso na língua. Esse network de sentidos arraigados é caracterizado a partir de protótipos e não através de divisões categóricas.

Dessa forma, acreditamos que determinados padrões identificados pelos estudos revistos anteriormente possam estar identificando efeitos de prototipicidade nesses verbos, possivelmente leituras mais prototípicas, do que limites precisos que resultariam em condições necessárias e suficientes para que dado verbo faça parte de determinada classe. 
Grafmiller (2013), que analisa os verbos psicológicos no inglês com ênfase nos verbos ObjExp, traz uma perspectiva que se diferencia dos estudos vistos na medida em que vai mostrar que as subdivisões normalmente propostas para os verbos ObjExp, baseadas na maior parte nos parâmetros de estatividade e agentividade, não se sustentam quando se olha para dados reais de uso da língua.

O autor vai argumentar contra uma divisão categórica dos verbos ObjExp, propondo que no inglês há uma gradiência em relação a esses parâmetros.

Uma das razões pelas quais Grafmiller (2013) critica divisões categóricas desses verbos em inglês é, segundo ele, o escopo limitado dos dados utilizados e o pouco consenso na classificação de quais verbos seriam os ditos estativos e não estativos. Os dados utilizados seriam normalmente aqueles construídos pelos autores como aceitáveis ou não, consistindo em um pequeno número de dados.

Outra razão citada pelo autor é que haveria evidência de que uma interpretação agentiva ou estativa estaria disponível para todos os tipos de verbos ObjExp, havendo apenas verbos que teriam uma tendência ou preferência a aparecerem mais em certos usos ou interpretações do que outros.

O intuito do autor é mostrar de forma quantitativa e qualitativa em contextos de uso mais reais e naturais de que há, portanto, uma gradiência e não divisões categóricas no inglês.

Para isso, o autor investiga fenômenos frequentemente citados na literatura como argumentos para a estatividade ou não estatividade dos verbos, como passividade, além de outras propriedades sintáticas citadas como próprias desses verbos.

Vimos, por exemplo, anteriormente que B\&R argumentam que verbos da classe de preoccupare não podem reflexivizar. Arad (1998, p.7), aliás, afirma que reflexividade só estaria presente na leitura agentiva dessa classe e não na estativa. Grafmiller (2013), no entanto, aponta dados de uso em seu corpus, com verbos considerados predominantemente estativos na literatura, que parecem indicar o contrário:

(15) a. I concern myself sometimes with the time i spend online Às vezes eu preocupo a mim mesmo com o tempo que eu gasto online.

b. Sometimes I even depress myself Às vezes eu até me deprimo. 
c. I worried myself for a bit there

Eu me preocupei um pouco naquele momento.

d. Weigh yourself in the morning one day and in the evening a few days later, and you'll only depress yourself for no reason

Pese-se de manhã um dia e à noite alguns dias depois e você só vai se deprimir sem razão.

$\left(\right.$ GRAFMILLER, 2013, p.43) ${ }^{37}$

Outro argumento que é bastante levantado para diferenciar verbos Subj-Exp de Obj-Exp são os compostos sintéticos no inglês, possíveis com verbos Subj-Exp, do tipo god-fearing man 'um homem temente a Deus' (cf. Grimshaw (1990)).

Grafmiller (2013) discute o fenômeno e mostra que exemplos de compostos sintéticos com verbos Obj-Exp podem ser achados no corpus e que nem sempre essas ocorrências podem ser justificadas como instanciando uma leitura agentiva desses verbos (como, por exemplo, (16e)):

(16) a. Peppy, the child-frightening clown

Peppy, o palhaço que assusta crianças.

b. They both have child-amusing characters

Ambos têm personagens que divertem as crianças.

c. a colleague tells me that a recent study of the parent-terrifying phenomenon of "sexting" found. . .

Um colega me contou sobre um estudo recente sobre o fenômeno de 'sexting' que assusta os pais achado...

d. Find recipes for Kid-Pleasing Spaghetti and other Baked Pasta recipes. Ache receitas de espaguetes que agradam às crianças e outras receitas de massas.

e. I passed the teenager-annoying noise test

Eu passei o teste de barulho que incomoda adolescentes.

(GRAFMILLER, 2013, p.54-55)

\footnotetext{
${ }^{37}$ As traduções livres apresentadas a partir dos dados do inglês do autor são de minha responsabilidade.
} 
Para o autor, dados como esses de compostos sintéticos, assim como de outros fenômenos que discute, apontam para a hipótese de que o argumento experienciador de verbos Obj-Exp seriam objetos afetados, o que constituiria um contra-argumento à hipótese de Landau (2010) de que seriam argumentos oblíquos.

Como mencionamos anteriormente, Grafmiller (2013), para verificar os argumentos levantados na literatura para a estatividade de certos verbos ditos inerentemente estativos como depress, worry e concern no inglês, vai focar em fenômenos como passividade e outros associados a ela.

Com base em dados de uso, o autor discute a distinção feita na literatura entre verbos que formariam passivas verbais (e, assim, ditos eventivos como scare) e verbos ObjExp que formariam apenas passivas adjetivais (os estativos, como depress).

$\mathrm{O}$ autor observa, com base em uma série de diagnósticos, que enquanto os verbos ObjExp formam, de fato, passivas adjetivais, não decorre, necessariamente que eles não possam formar passivas verbais.

Um argumento levantado para a suposta não ocorrência de certos verbos ObjExp (como depress) em passivas verbais é o uso do progressivo (em particular, do iterativo) e do passado pontual. Em razão do progressivo, e também do pontual, requerer uma interpretação eventiva ou processual não poderia ocorrer com passivas adjetivas que denotariam estados.

Grafmiller (2013) vai mostrar, no entanto, que é possível encontrar dados de uso naturais de verbos ditos obrigatoriamente estativos e também de verbos considerados obrigatoriamente não agentivos ocorrendo com o progressivo iterativo: ${ }^{38}$

(17) a. If you turn on the TV and are continually being bored by the programming, it's likely you have the wrong type of cable package

Se você liga a TV e está sempre sendo entediado pela programação, é sinal de que você tem o tipo errado de pacote de TV a cabo.

\footnotetext{
${ }^{38}$ Grafmiller (2013) observa que, embora a relação entre estatividade e agentividade ainda não seja completamente entendida, essas duas noções são frequentemente conectadas já que predicados estativos são tidos usualmente como não agentivos. Dessa forma, costuma-se encontrar agrupados nas mesmas listas (no que se refere ao seu comportamento gramatical) verbos citados como obrigatoriamente estativos como depress, worry e concern e verbos citados como obrigatoriamente não agentivos ou volitivos como alarm, amaze, astonish, captivate, delight, fascinate, horrify, e please.
} 
b. Our boys are constantly being depressed by watching their elder sister go off to Disney, on cruises, to Europe this summer with family,. . .

Nossos garotos estão constantemente sendo deprimidos por assistirem sua irmã mais velha ir à Disney, em viagens, à Europa nesse verão com a família...

c. If you are continually being worried by what you are publishing, you'll miss out on every one of the good stuff..

Se você está sempre sendo preocupado pelo o que você está publicando, você vai perder todas as coisas boas...

d. I am constantly being delighted by the wide variety of flavors that vegetables provide, flavors that are lost when they are relegated to 'side' dishes.

Eu estou em constante deleite pela variedade de sabores que os legumes fornecem, sabores que são perdidos quando eles são relegados a acompanhamentos.

e. She explained that she was constantly being pleased by Noldruk's advancements...

Ela explicou que as tentativas de Noldruk estavam sempre lhe agradando.

(GRAFMILLER, 2013, p.111-112)

Para o autor, o uso do progressivo iterativo nessas sentenças com esses verbos denota não que um determinado evento se repete, mas sim que o falante constrói uma situação em que o experienciador está pensando ou percebendo alguma entidade repetidas vezes.

Exemplos do passado pontual, modificados por advérbios como suddenly 'de repente', também foram encontrados com esses verbos:

(18) a. ... the thought of re-reading 'First among equals' suddenly depressed me ...o pensamento de reler 'First among equals' de repente me deprimiu.

b. These pretensions to morality, though, suddenly bored me ... Essas pretensões à moralidade, no entanto, de repente me entediaram...

c. The idea suddenly intrigued me

A ideia de repente me intrigou. 
d. Today I saw a post on Facebook that immediately concerned me Hoje eu vi uma postagem no Facebook que imediatamente me preocupou.

e. The mystery of the pyramid suddenly fascinated Landry and he even questioned Root. . .

O mistério da pirâmide de repente fascinou Landry e ele até mesmo questionou Root...

(GRAFMILLER, 2013, p.116)

Grafmiller (2013) argumenta que a variabilidade na aceitabilidade do uso desses verbos no passado pontual é devida não a uma diferença ontológica entre verbos estativos e não estativos e sim vai depender da probabilidade de o falante construir aquela emoção experienciada como ocorrendo mais abruptamente ou não. Verbos denotando medo, surpresa, choque, etc., teriam uma tendência maior a serem conceitualizados como a ocorrer de forma abrupta, já verbos denotando tédio ou depressão teriam uma tendência a serem conceitualizados como a emergir de forma mais gradual.

Da mesma forma, verbos como depress teriam uma tendência a ser conceitualizados como tendo um maior grau de permanência, enquanto o uso do progressivo seria mais usado para descrever situações que duram num determinado intervalo, com uma duração mais limitada (GRAFMILLER, 2013).

Há, portanto, uma gradiência em termos do uso dos verbos ObjExp, com alguns tendendo a ser construídos como emoções mais duráveis e que emergem mais gradualmente. Isso, no entanto, não exclui, como os dados que o autor mostra, a possibilidade de esses verbos serem construídos como a ocorrer de forma repentina e transiente, tal como verbos que descrevem emoções rápidas e abruptas como assustar, surpreender, etc.

Grafmiller (2013) observa, ao discutir as funções da passiva, que seriam os aspectos estativo-resultativos do evento os mais salientes na passiva e não aqueles relacionados ao agente (como causalidade). Por isso, seria realizada como intransitiva, distanciando-se de uma situação prototípica transitiva (HOPPER \& THOMPSON, 1980). 
Segundo o autor, a função cognitiva da passiva estativa (adjetival) seria então marcar, em verbos como worry e concern, o evento construído como uma relação disposicional ou atitudinal entre experienciador e o alvo (o estímulo) da emoção.

De modo a poder analisar de fato a ocorrência desses verbos em contextos reais de uso e os fatores que influenciam esse uso, Grafmiller vai analisar quantitativamente e estatisticamente os verbos ObjExp concern, depress, amaze, fascinate, amuse, annoy, scare, please, anger, upset, frighten, e surprise de acordo com parâmetros como o tipo de estímulo que é encontrado.

Para isso, o autor distingue o estímulo por tipos (cf. p.171 e discussão), humano (inclui organizações), não-humano animado, objeto concreto, evento, objeto estético (objeto feito com um propósito de despertar alguma resposta emocional ou psicológica), objeto abstrato (inclui locais e sensações) e objeto SoA (state of affairs).

Com base nesses tipos de estímulo e em sua ocorrência com cada verbo nos corpora analisados, o autor pôde gerar um gráfico 'biplot'. No gráfico, houve uma concentração dos verbos amuse, annoy, scare, please e startle ao redor dos tipos de estímulos humano e evento (este frequentemente fazendo referência a alguma atividade feita por um humano).

Para o autor, não é uma surpresa o fato de esse conjunto de verbos mais fortemente relacionados com estímulos humanos e eventos serem aqueles mais frequentemente associados na literatura a usos eventivos ou agentivos.

Uma segunda concentração de verbos no gráfico, composta pelos verbos astonish, concern, depress e horrify, ocorre ao redor do tipo de estímulo objeto abstrato que agrupa, por exemplo, sentimentos, atitudes, quantidades, propriedades, locais etc. ${ }^{39}$

Outros verbos como amaze, fascinate e captivate se concentraram ao redor de outros tipos de estímulos, amaze ao redor de objeto SoA, e captivate e fascinate ao redor de objeto estético e concreto.

No caso de amaze, o autor argumenta que o verbo denotaria uma apreciação mais duradoura e por isso sua ocorrência maior com estímulos mais persistentes no tempo como proposições, crenças e fatos (incluídos em objetos SoA).

Também os verbos como captivate e fascinate, e diferentemente de verbos como surprise que denotam emoções mais instantâneas, envolvem uma apreciação de

\footnotetext{
${ }^{39}$ Segundo o autor, o fato de verbos como concern aparecerem pouco com estímulos humanos (reais e não propriedades suas abstratas) explicaria por que a anáfora (forward binding) não seria tão frequente com esses verbos.
} 
estímulos mais persistente no tempo, como objetos estéticos e concretos (normalmente alguma propriedade sua), e que não seriam limitados temporalmente, podendo perdurar para além da situação imediata (assim como objetos SoA).

Dessa forma, Grafmiller (2013) argumenta que verbos que ocorrem com estímulos mais abstratos teriam uma tendência a serem construídos como estativos, sendo emoções mais 'apreciativas' em contraste com emoções mais 'reativas', mais instantâneas e rápidas e tendendo a serem construídas como emoções causadas de mudança de estado. Grafmiller (2013) associa de forma escalar e contínua o nível de potência (a capacidade de causar um evento) com o nível de abstração daquele objeto, assim quanto mais potente o estímulo (humano ou não-humano) menos abstrato seria e quanto menos potente mais abstrata seria a natureza do estímulo. $\mathrm{O}$ que indica, para o autor, que o tipo de estímulo influencia diretamente o uso desses verbos, correlacionando-se com diferenças notadas na literatura entre verbos ObjExp eventivos e estativos.

Diferentemente da literatura, no entanto, o autor defende que há usos prototípicos desses verbos, influenciados pelo contexto e pelas propriedades da sentença como um todo, e não como reflexo de uma classificação rígida e dicotômica entre verbos ObjExp eventivos e estativos.

Os ditos verbos não estativos (como amuse, annoy, scare, etc.) estariam associados a estímulos concretos ou humanos e a atividades e eventos delimitados temporalmente. Já verbos ditos estativos (concern, depress, etc.) estariam associados a ocorrências de estímulos abstratos como proposições, conceitos e propriedades. ${ }^{40}$

Em relação à agentividade, propriedade frequentemente citada na literatura para a diferenciação de verbos ObjExp, o autor também vai argumentar que a aceitabilidade de um verbo em um contexto agentivo ou não vai depender de inferências baseadas no

\footnotetext{
${ }^{40} \mathrm{O}$ autor também argumenta, com base em modelos de regressão logística aplicados aos corpora, que os verbos com tendência a ocorrerem com estímulos com uma potência maior teriam uma tendência a ocorrerem em sentenças ativas e transitivas, enquanto verbos ocorrendo com estímulos mais abstratos e menos potentes tenderiam a aparecer mais em construções intransitivas e passivas. Essa visão se alinha à visão de transitividade de Hopper \& Thompson (1980) em que transitividade é gradual e consequência de fatores globais envolvendo as sentenças no discurso e não uma propriedade só verbal. Prototipicamente, eventos breves e pontuais (como em startle) se aproximariam, nessa gradação ou continuum, do espectro transitivo, enquanto eventos duradouros e graduais (como em depress) se aproximariam mais do espectro intransitivo. Naturalmente, esses são valores prototípicos ou o construal default. Como exemplificado e defendido pelo autor, o uso desses verbos depende do contexto e não há uma dicotomia rígida entre verbos ObjExp estativos e eventivos como advogada pela literatura. Verbos como fascinate e horrify, por exemplo, não se encaixariam nesses padrões observados, já que o primeiro seria mais gradual e breve, enquanto o segundo mais repentino e duradouro.
} 
contexto de uso e de conhecimento de mundo e não determinada por diferenças lexicalizadas nas estruturas de evento desses verbos.

Grafmiller (2013) argumenta que a aceitabilidade em contextos agentivos de cada verbo é bem flexível, mostrando uma configuração fluída e não binária. Sendo que essa aceitabilidade é fortemente influenciada quando são adicionados outros elementos à sentença que favoreçam a leitura agentiva, i.e., informação contextual é crucial.

Dessa forma, ainda que alguns verbos favoreçam mais que outros uma interpretação agentiva, a aceitabilidade desses verbos é influenciada pelo conhecimento geral do sujeito sobre a emoção denotada pelo verbo, pelos argumentos do verbo (como o estímulo), pelas propriedades semânticas do verbo e pelo contexto discursivo imediato. $^{41}$

Revendo testes de agentividade frequentemente utilizados na literatura, Grafmiller (2013) exemplifica a aceitabilidade fluída desses verbos a partir de exemplos retirados de seu corpus que apresentam, em contextos naturais, verbos ObjExp ditos não agentivos em contextos agentivos, como com advérbios agentivos intentionally e deliberately:

(19) a. F. O'Connor, you must be equally sadistic to deliberately sadden your "sensitive child."

F. O’Connor, você deve ser igualmente sádico para deliberadamente entristecer sua 'criança sensível'.

b. I'm going to purposely bore you with this tip, but it TOTALLY WORKS Eu vou de propósito entediar você com essa dica, mas funciona totalmente.

c. I think it's about time we had a thread discussing the things you do to deliberately horrify and torment your wife.

Eu penso que é hora de abrirmos um tópico para discutir as coisas que você faz para deliberadamente horrorizar e atormentar sua esposa.

d. The politicians and health police deliberately depress us, so we'll pay the outrageous taxes on smoking products to cheer ourselves up.

Os políticos e o policiamento do que é saudável deliberadamente nos deprime, assim nós temos que pagar impostos ultrajantes em produtos de fumar para nos animarmos.

\footnotetext{
${ }^{41}$ Nesse ponto, a semântica lexical do predicado contribuiria para o significado da sentença de forma parcial, sendo parte de um processo complexo de conceitualização. Talvez daí as diferenças de julgamento a partir de sentenças descontextualizadas.
} 
e. Slick male foreigners talk funny to deliberately fascinate older women who don't know any better.

Homens habilidosos estrangeiros falam de forma engraçada para deliberadamente fascinar mulheres mais velhas que não conhecem nada melhor.

(GRAFMILLER, 2013, p.224-225)

Como nota o autor, exemplos como esses soam naturais e fazem sentido, pois estão dentro de um contexto discursivo muito mais rico e não isoladamente. ${ }^{42}$

Para testar estatisticamente a aceitabilidade de diferentes verbos ObjExp, e não apenas aqueles mais representativos de cada extremo, Grafmiller (2013) conduz uma pesquisa em que um número de sujeitos dão notas numa escala de 1 a 7 a diferentes sentenças com verbos ObjExp, sendo utilizados advérbios (intencionalmente, deliberadamente), imperativos, o progressivo e complementização de verbos de controle (como 'persuadir').

O que os resultados mostram é que há muito mais variabilidade entre os verbos, havendo verbos em posições intermediárias, e não uma distinção binária entre verbos agentivos versus não agentivos. Ou seja, não há uma distinção clara entre dois grupos de verbos e sim um contínuo, em que há verbos que tendem a se aproximar mais de um dos extremos e outros que ficam em posições intermediárias entre os dois extremos, não sendo possível desenhar uma linha precisa onde terminam os verbos agentivos e onde começam os não agentivos.

A importância de se levar em conta a natureza do estímulo na descrição dos verbos psicológicos também foi explorada por Levin \& Grafmiller (2013), dessa vez, fazendo um estudo baseado em corpus de verbos SubjExp e ObjExp como fear e frighten respectivamente.

Em primeiro lugar, os autores argumentam que os dois tipos de verbos não são equivalentes e sim denotariam dois tipos distintos de eventos psicológicos. ${ }^{43}$ Ainda que em algumas circunstâncias e contextos, esses verbos possam ser trocados sem causar perda semântica, em outros a troca gera sentenças que soam, no mínimo, 'estranhas', as sentenças retiradas do corpus pelos autores exemplificam o argumento:

\footnotetext{
42 Grafmiller argumenta, assim, que a aceitabilidade ou não de um verbo em contextos agentivos não resulta de alguma restrição semântica desses verbos e sim de uma dificuldade em se imaginar uma situação em que aquela emoção denotada pelo verbo possa ser causada pelo outro.

${ }^{43}$ Os autores também citam o fato de que nem todos verbos psicológicos são encontrados em pares (os mais frequentemente citados sendo fear/frighten e like/please), i.e., na maior parte dos casos não há a contraparte ObjExp ou vice-versa.
} 
(20) a. They dropped everything and ran when something frightened them.

Eles largaram tudo e correram quando alguma coisa os assustou.

a'. ??They dropped everything and ran when they feared something.

??Eles largaram tudo e correram quando eles temeram alguma coisa.

b. He "hesitated fatally on the edge of his own political transformation.

.. He feared the new."

Ele hesitou fatalmente na beira de sua própria transformação política... Ele temia o novo.

b'. $\quad$ ??He "hesitated fatally on the edge of his own political transformation.

. The new frightened him."

??Ele hesitou fatalmente na beira de sua própria transformação política...

O novo o assustou.

(LEVIN \& GRAFMILLER, 2013, p.24-25)

Para os autores, essa falta de equivalência em alguns contextos emerge de usos diferentes desses verbos. Os autores demonstram, através de uma análise quantitativa do corpus, que verbos como fear tendem a ocorrer com estímulos abstratos, como propriedades, proposições e conceitos. Enquanto verbos como frighten tendem a ocorrer com entidades mais concretas, como humanos, eventos e objetos físicos.

Essa maior ocorrência do verbo fear com entidades abstratas é interessante, pois também mostra uma tendência a conceitualizar esses estímulos como eventos hipotéticos ou futuros que ainda não ocorreram, enfatizando a disposição do experienciador em relação a determinado alvo.

Mesmo quando o verbo fear ocorre com estímulos humanos, os autores notam que esses são muitas vezes qualitativamente diferentes daqueles que ocorrem com frighten, podendo ser, por exemplo, conceitualizações abstratas desses humanos ou mesmo indicando algum tipo de assimetria de status, o estímulo no papel de autoridade ou de uma entidade de reverência.

A tendência de verbos como frighten de ocorrerem com estímulos mais concretos, como humanos e eventos no contexto imediato, Levin \& Grafmiller (2013) atribuem ao caráter mais causativo desse tipo de verbo, a emoção sendo causada de forma mais direta, o que contrastaria com o verbo fear, em que a emoção seria mais 
dirigida ao estímulo, i.e., marcaria uma disposição em relação ao estímulo mais do que uma reação causal ao estímulo.

Acreditamos que, primeiro, os resultados desses estudos indicam que a diferenciação dos verbos psicológicos, frequentemente manifestada em mapeamentos ou comportamentos sintáticos, não é fruto de estruturas sintáticas ou temáticas subjacentes distintas, mas sim resulta de organizações conceituais diferentes, englobando a sentença como um todo (o verbo, os participantes, o aspecto, tempo, o tipo de construção, etc.) e seu contexto discursivo (o contexto comunicativo e discursivo mais imediato, conhecimentos prévios, etc.). Todos esses fatores são indissociáveis e sinalizam construals distintos dos eventos, i.e., formas distintas de se construir eventos nas línguas.

Decorre que, em segundo, os diferentes tipos de verbos psicológicos podem ser conceitualizados de formas distintas, havendo mais tendências, construals mais prototípicos, do que classes de verbos com limites precisos.

Em relação ao primeiro, e que se relaciona ao segundo, acreditamos que esses resultados também sejam válidos para outras línguas, assim como o são para o inglês como argumentado por Grafmiller (2013). E o português é um exemplo.

Apesar de classificações como a proposta por Cançado (1996) serem importantes na medida que podem indicar tendências e nuances de significação apresentadas pelos verbos psicológicos no português, são difíceis de se manter de forma restrita quando confrontadas com dados de uso.

No texto, a autora argumenta que enquanto as classes que propõem 1, 3 e 4 apresentam o traço [+controle] em seu argumento sujeito, em classes como a 2 (que inclui verbos como preocupar, magoar, decepcionar, horrorizar, etc.) esse traço seria inexistente. Para Cançado (1996), esses verbos não permitiriam uma leitura agentiva, sendo apenas causativos e não agentivos.

Essa diferenciação é mantida em Cançado (2012), mas com modificações. O argumento principal da autora, no texto, é que a propriedade 'ser psicológico' não é uma propriedade relevante gramaticalmente, i.e., os verbos psicológicos não constituiriam uma classe especial de verbos gramaticalmente. ${ }^{44}$

\footnotetext{
${ }^{44}$ A questão é controversa na literatura (cf. Landau (2010), Grafmiller (2013) e Rozwadowska (s/d)) e há aqueles que defendem que os verbos psicológicos constituem sim uma classe especial de verbos e outros que acreditam que os verbos psicológicos não são especiais gramaticalmente, comportando-se como outros verbos na língua. Acreditamos que apesar de algumas propriedades atribuídas aos verbos psicológicos não serem, de fato, exclusivas deles, ou seja, são encontradas em outros verbos não
} 
Para isso, a autora utiliza a classificação feita em Cançado (1996) para argumentar que essas classes, na verdade, têm o mesmo comportamento gramatical de outras classes de verbos não psicológicos do português. A classe 3 e 4 (com verbos como 'acalmar'), a autora passa a considerar como uma só, considerando-os como verbos causativos ou agentivos e que se comportariam como outros verbos causativos/agentivos da língua como 'quebrar'.

A classe 2, verbos como 'preocupar', seriam apenas causativos e não agentivos e se comportariam como outros verbos não psicológicos como 'cansar' e 'enriquecer'. Como evidência dessa distinção, a autora aponta que, ao contrário de verbos de classe 3 e 4, verbos de classe 2 não ocorrem na passiva sintática e nem podem ocorrer com um instrumento.

Como pontuado por Grafmiller (2013), um dos problemas com classificações como essas é que é incerto quais verbos, de fato, pertenceriam a cada classe. Acreditamos que a mesma dificuldade valha para o português, em que não fica claro o limite, nem parece haver limites precisos, entre as classes de verbos propostas. Por exemplo, dos verbos citados como da classe de 'preocupar', alguns são facilmente encontrados em passivas sintáticas como 'magoar' e 'decepcionar', outros como 'aborrecer' são mais raros em passivas, mas ainda assim é possível achar exemplos desse verbo em passivas em contextos naturais de uso:

(21) a. Você amou e foi magoado, agora fala que "amor não existe". Claro que existe.

b. Às vezes simples desculpas, sinceras e honestas, poderão ser suficientes para que a pessoa acredite que você realmente se arrependeu, e o arrependimento ajuda bastante a passar a dor, dos dois, de quem magoou e de quem foi magoado.

c. Ela viveu no mundo com tantas pessoas decepcionantes à sua volta. Foi decepcionada várias e várias vezes, foi traída, se tornou muito cautelosa, hesitante.

d. Quem nunca foi aborrecido por algo ou alguém em certo momento da vida? Todos nós já enfrentamos algum destes aborrecimentos que a vida nos impõe e nem sempre gostamos de enfrentar essas situações.

psicológicos, há línguas (como o georgiano) que os codificam de forma diferenciada, tornando-os mais marcados gramaticalmente, indicando possivelmente que há características desses verbos que os afastam conceitualmente de eventos canônicos físicos, por exemplo. 
e. O judiciário inventou uma coisa bem fofinha: se você foi "aborrecido" por uma empresa, não ganha indenização; só ganha se foi dano moral... Mas o que é um ou outro?

f. Além disso, pode se referir a quem teve a raiva despertada, que está irritado, exasperado, ou seja, que foi aborrecido por alguém.

(Dados retirados do Google ${ }^{45}$ )

Quanto à agentividade, verbos como 'magoar e 'preocupar' podem ser encontrados em contextos que facilitam uma interpretação agentiva tanto do sujeito experienciador (no caso de magoar-se e preocupar-se em (22)) quanto do estímulo causador da emoção (em (23), i.e., denotam um grau maior de controle por parte do sujeito):

(22) a. Use frases como "Foi você mesmo quem se ofendeu" ou "Você é quem está ofendendo a si mesmo". Estes são os tipos de declarações que o impedem de sentir-se culpado e que colocam a responsabilidade de alguém sentir-se ofendido onde ela deve estar, isto é, com a pessoa que resolveu se magoar ou se ofender.

b. Por exemplo, o caso de uma senhora que se preocupava demais com a saúde do neto, foi viajar e quase nem desfrutou direito da viagem achando que poderia acontecer algo ruim com ele, mesmo ele estando com os pais que são pessoas competentes. Quando voltou da viagem viu que o neto estava bem e finalmente ficou aliviada. Mas por coincidência logo depois este neto ficou doente. Pronto! Na cabeça dela o neto só ficou doente porque ela parou de se preocupar, e isso "provou" que ela não deve parar de se preocupar com ele.

c. Quando parei de me preocupar com o que pensavam e me preocupei comigo, no meu pensar sobre as pessoas, logo tudo mudou e perdi a timidez.

d. Eu decidi parar de me preocupar com as coisas. Se você se preocupa, você só se desaponta o tempo todo.

\footnotetext{
${ }^{45}$ Fontes correspondentes a cada exemplo, respectivamente:

https://www.pensador.com > Pensador

toquedemotivacao.com.br/category/toques-motivacionais/page/77/

humaniversidade.com.br

https://sonhos.com/aborrecimento/

www.osul.com.br > Notícias > Brasil

http://www.significando.com.br/acirrado/
} 
(Dados retirados do Google ${ }^{46}$ )

(23) a. Por que ele quis me magoar de propósito? Raiva, amor, maldade?

b. Vcs já magoaram ou magoariam alguém de propósito? Como vocês se sentiram? Pediram desculpas depois?

c. Às vezes acho que ela gosta de me preocupar de propósito.

d. [Ele] Estava me torturando, me obrigando a esperar ali e a me preocupar de propósito. Afinal, devagar, ele arrancou a folha do bloco e a entregou a mim.

(Dados retirados do Google ${ }^{47}$ )

Ainda que exemplos como os citados acima não sejam tão frequentemente encontrados, são possíveis no contexto discursivo, indicando conceitualizações distintas dos eventos psicológicos. Como foi argumentado por Grafmiller (2013), há leituras mais prototípicas associadas aos verbos, como mais ou menos agentivos, havendo um contínuo e não classificações restritas. Assim, verbos como 'acalmar' poderiam ser considerados como mais agentivos, facilitando sua ocorrência nesses contextos. Já verbos como 'preocupar' e 'deprimir' tenderiam a contextos menos agentivos. De qualquer forma, tanto 'acalmar' quanto 'preocupar' são suscetíveis a ambas as construções, agentivas e não agentivas.

Os exemplos em (22) nos mostram que, apesar de verbos como 'preocupar' e 'magoar' serem usualmente ações não controladas pelo experienciador, com pouca ou nenhuma intencionalidade, há contextos em que uma interpretação agentiva é possível, denotando que o experienciador tem maior controle ou poder sobre aquele estado psicológico, podendo interrompê-lo (22b, c, d) ou infligi-lo em si mesmo (22a).

\footnotetext{
${ }^{46}$ Fontes correspondentes a cada exemplo, respectivamente: paulofaria.blogspot.com.br/2008/10/no-se-deixe-manipular-pelos-outros-dr.html apsicologiaonline.com.br/2014/11/transtorno-de-ansiedade-generalizada/ http://www.renatocardoso.com/blog/2013/05/29/o-que-pensam-de-mim/ https://brainly.com.br

${ }^{47}$ Fontes correspondentes a cada exemplo, respectivamente: https://br.answers.yahoo.com/ (Yahoo respostas) https://br.answers.yahoo.com/ (Yahoo respostas) https://spiritfanfics.com > Between Rivals https://www.wattpad.com/448373537-exclusivo-vol-1-não-há-exceções
} 
Os exemplos em (23), apesar de não serem comuns, exemplificam contextos em que o estímulo ou causa é interpretado como tendo intenção e volição sobre o evento.

Como Grafmiller (2013) comenta, as emoções não são diretamente acessíveis a forças ou agentes humanos externos, são as ações intermediárias produzidas que afetam as pessoas. E essas ações, por sua vez, podem ou não afetar o experienciador, assim como podem ser ou não ser controladas pelo agente ou força. E, acreditamos, que isso é válido tanto para eventos como 'acalmar' quanto 'preocupar', os agentes ou forças externas não são diretamente responsáveis pela forma como nos sentimos afetados por elas. A capacidade de alguém nos acalmar ou preocupar é mediada por alguma ação intermediária que pode ou não surtir efeito.

Talvez, a maior facilidade de verbos como 'acalmar' serem conceitualizados como ações mais agentivas decorra do fato de que é mais fácil imaginar contextos em que uma ação intermediária que tenha o efeito de acalmar seja produzida, do que imaginar um contexto em que uma situação que tenha o efeito de preocupar seja produzida intencionalmente.

Cançado (2012), por exemplo, ao argumentar que verbos da classe 2 não podem ocorrer com instrumentos $(24 \mathrm{~d}, \mathrm{e})$ e as classes 3 e 4 poderiam (24a, b, c), fornece os seguintes exemplos:

(24) a. O João assustou a Maria com um revólver.

b. O João acalmou a Maria com um chá.

c. A babá malvada traumatizou o menino com histórias de terror.

d. *A filha preocupou a mãe com uma faca.

e. $\quad *$ O João aborreceu o pai com um martelo.

(CANÇADO, 2012)

Na medida em que é fácil imaginar contextos em que (24a, b, c) sejam possíveis, isto é, costuma-se acalmar pessoas com chás ou assustar pessoas com revólveres, é mais difícil imaginar contextos em que (24d, e) façam sentido. O problema, parece-nos, não é a impossibilidade inerente de verbos como 'preocupar' e 'aborrecer' serem interpretados de forma agentiva, e sim a falta de um contexto discursivo que favoreça e 
dê pistas ao falante dessa interpretação (levando em consideração, inclusive, a natureza do estímulo), tal como nos exemplos em (23). ${ }^{48}$

Compare, por exemplo, a sentença em (24c), que para Cançado (2012) é uma sentença agentiva e com um complemento instrumental 'histórias de terror', e as sentenças em (25):

(25) a. Ele me magoou com palavras fortes, é melhor deixar do jeito que está. Decidi tirar aqueles pensamentos da minha cabeça e terminar

b. A essa altura a cunhada resmungou: "Por que essa megera nos aborrece com essas histórias?"

(Dados retirados do Google ${ }^{49}$ )

Se o raciocínio de Cançado (2012), de uma leitura agentiva e com um instrumento de complemento, pode ser aplicado ao exemplo com o verbo 'traumatizar' em (24c), poderia igualmente ser aplicado aos exemplos em (25), em que o sujeito 'ele' e 'megera' podem ter agido intencionalmente dizendo palavras e histórias, respectivamente, que magoassem e aborrecessem o experienciador.

Ou mesmo, é possível considerar que o contrário seja válido, se for para interpretar os exemplos em (25) como tendo um complemento causal e o sujeito como não agentivo, o exemplo da autora (24c) com 'traumatizar' também poderia ser interpretado dessa forma. Já que se pode perfeitamente argumentar que o sujeito 'babá malvada' não teve intenção de 'traumatizar' o menino com suas histórias, mas apenas lhe dar um susto. ${ }^{50}$

\footnotetext{
48 Outros exemplos de verbos não psicológicos com os quais a autora compara o comportamento gramatical também podem ser questionados por falta de um contexto apropriado. Por exemplo, a autora fornece um exemplo com o verbo 'enriquecer' que seria agramatical com a seguinte estrutura ' $O$ pai enriqueceu o João com dinheiro' (p.14), no entanto, não é difícil encontrar exemplos dessa mesma estrutura com o verbo 'enriquecer' sendo utilizada em contextos que fazem completo sentido como: '[...] uma homenagem à comunidade que chegou ao Brasil no início do século passado e enriqueceu o País com sua cultura e sua gastronomia.'

(Exemplo retirado de: https://issuu.com/esporteclubepinheiros/docs/revista_agosto/20).

${ }^{49}$ Fontes correspondentes a cada exemplo, respectivamente:

encantobrs.blogspot.com.br/2013/01/

https://books.google.com.br/books?isbn=8563397818

50 Naturalmente, outros fatores influenciam uma interpretação de maior ou menor intencionalidade entre as sentenças que não são decorrentes apenas da escolha do verbo, por exemplo, a sentença em (24c) é afirmativa e está no tempo passado e o sujeito carrega o adjetivo 'malvada', fatores que
} 
Dessa forma, acreditamos que as leituras mais prototípicas de cada verbo emergem do uso, envolvendo uma série de fatores (inclusive conhecimento de mundo, cultural, social e físico) e em que diferentes propriedades podem ser enfatizadas ou salientadas.

Mendes (2002), analisando os verbos psicológicos no português de Portugal, procura mostrar que o comportamento dos verbos ObjExp no português apresenta certas propriedades prototípicas, havendo outras que seriam mais particulares a certos verbos ou mais lexicalizadas.

A autora nota, por exemplo, que alguns poucos verbos como 'humilhar' e 'lisonjear' permitiriam a não ocorrência do estado resultativo (em (26)), característica que soa estranha ou contraditória com outros verbos.

O Rui humilhou-me diante dos meus amigos mas eu não me senti humilhado.

(MENDES, 2002)

A autora atribui esse dado também à maior agentividade de verbos como 'humilhar', em que haveria uma maior ênfase na ação praticada pelo sujeito.

É interessante ainda notar que assim como Grafmiller (2013) considera a natureza do estímulo e sua associação a fatores aspectuais dos verbos ObjExp, Mendes (2002) observa uma relação entre aspecto e uma maior ou menor ênfase do estímulo como causa ou objeto da emoção. Verbos menos pontuais como 'preocupar' enfatizariam mais o estímulo como objeto da emoção, enquanto o verbo 'assustar', mais pontual, enfatizaria o aspecto causal do estímulo.

Esses pontos são importantes trazer, pois mostram que diferentes propriedades podem ser enfatizadas por determinados verbos e em determinados contextos, havendo uma relação complexa entre essas propriedades, como os participantes, fatores aspectuais, etc.

favorecem a interpretação agentiva. Enquanto a sentença em (25b) está no presente e em discurso direto, sinalizando o julgamento da personagem a respeito do outro e podendo influenciar o uso do termo 'megera' e o fato de ela achar suas histórias 'aborrecidas', não implicando necessariamente intencionalidade por parte do sujeito. Outro fator que influencia é a natureza dos eventos descritos pelos verbos 'aborrecer' e 'traumatizar' que não se relacionam à agentividade ou não do estímulo e sim ao efeito produzido. Enquanto 'aborrecer' costuma denotar um evento mais passageiro, 'traumatizar' é um evento mais permanente, dessa forma, se trocados os verbos na frase 'Por que essa megera nos traumatiza com essas histórias?', a tendência é darmos mais 'crédito' ao julgamento feito, como de fato um ato maldoso consumado (e, talvez, intencional), do que com o verbo 'aborrecer'. 
Com verbos como 'deprimir', que usualmente são conceitualizados como eventos não pontuais e que emergem gradualmente (cf. discussão sobre a análise de Grafmiller (2013) acima), há ocasiões em que esse verbo pode ser encontrado denotando um evento repentino:

(27) a. Você já ficou deprimido de repente? O que fazer?

b. Marcello finalmente entendeu que ela não estava brincando, que realmente o considerava muito inferior a uma lesma, a um verme, e de repente ficou deprimido.

(Dados retirados do Google ${ }^{51}$ )

Dessa forma, na descrição da significação desses verbos, há a necessidade de se considerar os aspectos envolvidos nas sentenças e no discurso de forma mais global, em outras palavras, verbos não ocorrem isoladamente, seu uso e significado emergem do uso em contextos morfossintáticos e discursivos maiores.

É a partir do uso que podemos dizer que um verbo tem sentidos mais prototípicos. Essa prototipicidade não exclui, como temos discutido, o fato de o verbo poder ser construído de formas distintas. Além do mais, não há categorias de verbos ObjExp dicotômicas, a dividir aqueles agentivos/eventivos e os não agentivos/estativos e sim, há uma gradiência entre esses verbos em termos de fatores como agentividade e estatividade.

Antes de finalizarmos esta seção, queremos explicitar a análise de Croft (1993) que tentou explicar a variação observada translinguisticamente na marcação de experienciadores e estímulos de verbos psicológicos. Sua análise é particularmente importante para esta tese, pois introduz a noção de bidirecionalidade de eventos experienciais.

Croft (1993), considerando eventos como cadeias causais em que sua sequência é definida em termos de um participante agindo sobre o outro, define o evento prototípico como aquele em que um participante age de forma volitiva sobre o outro participante que, por sua vez, é afetado sofrendo uma mudança de estado. Nesse evento

\footnotetext{
${ }^{51}$ Fontes correspondentes a cada exemplo, respectivamente: https://br.answers.yahoo.com/ (Yahoo respostas) https://books.google.com.br/books?isbn=8525061069
} 
prototípico e assimétrico (em termos de transmissão de força), ao primeiro participante, o iniciador do evento, é atribuída a posição de sujeito, enquanto ao segundo participante, o ponto final, é atribuída a posição de objeto.

A partir dessa definição, o autor vai tentar explicar as diferentes marcações apresentadas por verbos mentais, considerando a estrutura de eventos que esses verbos teriam. Para o autor, seriam especificamente os verbos mentais estativos, devido à sua estrutura de evento, que apresentariam variação translinguisticamente.

O autor vai começar diferenciando quatro tipos de verbos mentais: os causativos (representados pela estrutura em (28a)) tais como please, nesses casos, a estrutura sempre seria a mesma, isto é, o estímulo como sujeito e experienciador como objeto de forma que o primeiro causa uma mudança de estado no último; verbos de atividade mental tais como think, consider, em que há um maior controle por parte do experienciador e por isso este seria sempre codificado como sujeito; verbos mentais incoativos tais como get angry, get bored que denotariam o início do estado mental, sem necessariamente referência à causa externa da mudança de estado, por essa razão, o experienciador, representando a porção inicial do evento, também seria sempre codificado como sujeito; e por fim, verbos mentais estativos como like, know, representados pela estrutura em (28b), em que não haveria uma mudança de estado, nem transmissão de força:

(28) a. Verbos Mentais Causativos

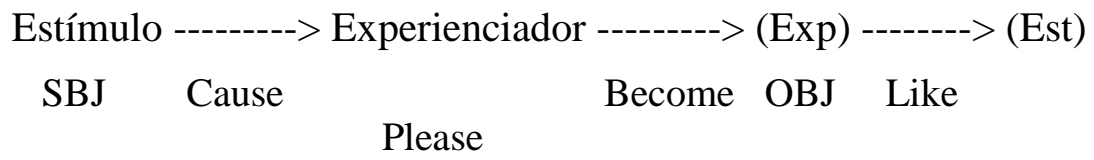

b. Verbos Mentais Estativos

Experienciador ----------- Estímulo
SBJ

Like

(CROFT, 1993) 
Segundo o autor, os verbos mentais causativos são processos envolvendo três segmentos causais. Seria o primeiro segmento, o de causa, que representaria a transmissão de força, fazendo com que o estímulo seja posicionado como sujeito.

Já os verbos mentais estativos seriam compostos por um único segmento estativo que não envolve transmissão de força e, assim, o estímulo não seria afetado. Para Croft (1993), um fator importante dessa estrutura seria o fato de que não haveria uma direcionalidade inerente como ocorre em estruturas causais (com transmissão de energia de um participante a outro), e seria justamente por essa razão que o autor argumenta que haveria variação translinguisticamente na atribuição do experienciador à posição de sujeito ou objeto, especificamente com verbos mentais estativos. Variação esssa que não ocorreria com os outros três tipos de verbos mentais citados acima que envolveriam mudança de estado ou maior controle do experienciador.

Segundo o autor, há dois processos envolvidos em se possuir ou mudar um determinado estado mental: primeiro, o experienciador precisa dirigir sua atenção ao estímulo; e segundo, o estímulo ou alguma propriedade sua causa a entrada do experienciador em dado estado mental:

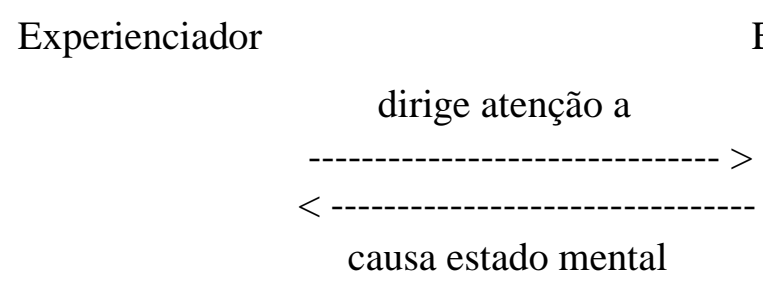

(CROFT, 1993)

Essa relação causal bidirecional implica que tanto o experienciador quanto o estímulo sejam simultaneamente o iniciador e o ponto final energético. Por essa razão, nenhum dos dois seria nem o iniciador nem o ponto final energético prototípicos (cf. discussão sobre Dowty (1991) acima).

Croft (1993), ao discutir o reflexo dessa bidirecionalidade na gramática das línguas, observa que em determinadas línguas a marcação do experienciador como 
sujeito está mais associada a uma interpretação mais volitiva em oposição à construção em que o experienciador é marcado como objeto. O autor dá o exemplo do espanhol:

(30) a. Olvidé hacerlo

Eu esqueci de fazer

b. Me olvidé de hacerlo

Eu me esqueci de fazer

c. Se me olvidó hacerlo.

Eu me esqueci de fazer

(CROFT, 1993)

Segundo o autor, a sentença em (30a) com o experienciador na posição de sujeito implicaria um maior controle em que o ato de esquecer foi intencional. Em (30b), a forma pronominal, implica um esquecimento involuntário, mas em que o experienciador é responsável. Em (30c), a construção impessoal, o experienciador não seria nem responsável, nem intencional.

Croft (1993) prossegue dando exemplos em diversas línguas com base nas diferentes conceitualizações associadas a cada construção.

No inglês, por exemplo, o autor discute a diferença dos exemplos abaixo, em que no primeiro exemplo, prefere-se o estímulo na posição de sujeito quando alguma propriedade é atribuída a ele, já quando alguma propriedade é atribuída ao experienciador, este é colocado na posição de sujeito como na segunda sentença:

(31) a. The peak is visible from hundred of miles.

O pico é visível de centenas de quilômetros.

b. John can see the peak from here, but my eyes aren't good enough.

John pode ver o pico daqui, mas meus olhos não são bons o suficiente. 
Acreditamos que a ideia de bidirecionalidade que Croft propõe para os verbos mentais estativos em particular, pode ser estendida aos eventos experienciais no geral, isto é, a hipótese é de que conceitualizamos os eventos experienciais como bidirecionais e isso se reflete na gramática das línguas. A variação encontrada nas línguas, portanto, seria reflexo de formas diferentes de se conceitualizar os eventos psicológicos a partir de sua característica bidirecional e, como argumentaremos no capítulo 7, fundamentalmente metafórica.

Como temos também discutido até aqui, acreditamos que essa característica dialoga com diversos fatores na escolha de construções distintas: participantes distintos (experienciador e estímulo) podem ter mais ou menos proeminência e serem construídos tanto como fonte de energia quanto como ponto final energético do evento.

Ainda que nosso foco esteja nas construções com experienciadores no dativo, já que um recorte deve ser feito, pensamos ser produtivo e necessário que outras construções também sejam levadas em consideração, justamente em razão de acreditarmos que indícios da conceitualização de eventos experienciais com marcação dativa jazem também em outras construções com verbos experienciais.

É na observação de outras construções que acreditamos que algumas propriedades emergem e refletem de modo geral a maneira como são conceitualizados eventos experienciais nas línguas e são, na verdade, dois lados da mesma moeda. Ademais, é importante notar que construções experienciais não existem isoladamente no sistema das línguas, pelo contrário, sofrem influência de outras construções e, naturalmente, estão sujeitas aos recursos que as próprias línguas dispõem.

A diferença que pôde ser observada até então entre verbos SubjExp e ObjExp envolve uma relação complexa entre diversos fatores. E atribuir sua diferença a apenas um ou dois deles nos parece incompleta. Ainda que não tratemos de fatores aspectuais nesta tese, por uma questão de viabilidade, é reconhecido que são fatores influentes e que dialogam com outras propriedades, como a proposta de Grafmiller (2013) e Levin e Grafmiller (2013) colocaram em evidência ao mostrar que a natureza do estímulo (se mais abstrato ou concreto) e do contexto discursivo influencia na escolha da construção e no seu grau de estatividade/agentividade. 
Dessa forma, atribuir sua diferença a apenas a estatividade/não agentividade versus eventividade/agentividade não parece captar de forma plena as propriedades que estão sendo mobilizadas.

Um fator conceitual que justamente pensamos faltar em análises que tratam das diferenças entre verbos experienciais ObjExp e SubjExp (e também com marcação dativa) é a bidirecionalidade desses eventos e também os processos metafóricos envolvidos na conceitualização e codificação desses eventos. Uma visão mais completa desses aspectos será dada no capítulo 7. No momento, apenas apontaremos como o aspecto bidirecional, apontado inicialmente por Croft (1993), é importante.

Tomemos alguns exemplos do português abaixo. Observe que esses eventos são concebidos ou a partir de uma fonte externa a nós ou a partir de nós como aqueles que experienciam ou dirigem sua atenção a essa fonte:

(32) a. Eu apenas te coloquei em outro lugar da minha vida, aquele no qual você não me incomoda mais!

b. De forma sucinta e clara deu uma aula sobre como escolher um curso fora do país.... valeu pelas dicas, amiga... isso me lembra nossa conversa pelo msn esses dias....

c. Eu quis deixar super claro que não tava querendo dizer que o fulano ou s / cicrano deveriam fazer, longe de mim, mas quis deixar claro também que não concordo muito com essa quantidade absurda de' ' mais do mesmo'. Isso cansa e cansa e cansa...

d. [...] o fato de vocês estarem juntos há tantos anos atrapalha você a aceitar isso

e. Com a certeza de que cansei os meus dois leitores, cesso estas digressões.

(Dados retirados do Google ${ }^{52}$ )

\footnotetext{
52 Fontes correspondentes a cada exemplo, respectivamente: https://www.pensador.com > Pensador > Eu ainda não te esqueci https://fashiongazette.wordpress.com/2008/ http://ahoradevirarborboleta.blogspot.com/2013/07/da-dificil-arte-de-manter-um-blog.html http://www.pergunteaumamulher.com/2012/05/o-que-fazer-quando-o-encanto-da-relacao.html acervo.revistabula.com
} 
Nos cinco exemplos em (32), o experienciador está na função de objeto. Em (32a), o foco primário recai sobre o participante 'você' e o efeito que causa (ou causava) no experienciador. Em (32b), é o contexto discursivo anterior que é retomado através do pronome demonstrativo 'isso', sendo conceitualizado como aquele que provoca a lembrança no experienciador de um fato ocorrido (a conversa). Dado semelhante ocorre em (32c), em que o pronome 'isso' retoma o contexto anterior relatado pelo experienciador como causa de seu cansaço.

Em (32d), o 'fato' relatado pelo falante é tido como a causa do evento emocional de 'atrapalhar' o experienciador. Já em (32e), o próprio falante se coloca como a causar o cansaço de seus leitores.

Como vimos anteriormente na discussão sobre a análise de verbos ObjExp na literatura, o componente 'causa' é considerado por vezes como um papel temático distinto, por outras é considerado como um componente aspectual.

Acreditamos que o componente 'causa' apontado na literatura resulta, não de uma propriedade intrínseca dos verbos, mas sim das diferentes possibilidades de se conceitualizar os eventos, na medida em que participantes distintos podem ser perfilados, assim como diferentes aspectos do conteúdo perfilado pelo verbo podem ganhar maior ou menor proeminência conceitual.

Nos exemplos acima, o estímulo é escolhido como fonte de energia do evento e como foco primário da construção. Sua saliência conceitual é favorecida pelo discurso, em que o estímulo é o foco de atenção. Fato que é refletido gramaticalmente ao ser colocado como sujeito.

Se considerarmos um processo verbal como uma cadeia de ação, em que um participante age sobre o outro, havendo transmissão de energia, o fato de o estímulo receber proeminência primária salienta a porção inicial do evento em que um participante causa um efeito sobre o outro. Nesse caso, o experienciador é colocado como foco secundário e é afetado pelo evento, sendo, nesses casos, conceitualizado como ponto final energético do evento, aquele que metaforicamente recebe a emoção. Alguns exemplos de construções perifrásticas de emoção mostram a relação causal que o estímulo assume e a relação do experienciador como aquele que recebe a emoção:

(33) a. Essa morte que outrora me enchia de temor e desespero e que eu tanto temia a chegada agora já não me causa preocupação 
b. "Não me causa preocupação", diz o deputado sobre movimento para derrubá-lo.

c. Falo uma coisa: Isso não é nada perto do orgulho que dá quando vc vê aquele sorriso ou a evolução dos movimentos

d. Meu filho tem 2 anos e meio, vou te dizer, ainda tem horas que dá vontade de trancar ele num quartinho e colocar um protetor auricular no ouvido

e. ele não motiva ninguem, essa cara de choro e de perdedor me dá uma raiva danada.

(Dados retirados do Google ${ }^{53}$ )

Em (33a, b), os temas de 'morte' e 'movimento' são a causa da preocupação e são codificados através da perífrase com o verbo 'causar' mais o substantivo denotando 'preocupação'. Em (33c, d, e), é usada a perífrase com o verbo 'dar', em que a emoção 'orgulho', 'vontade' e 'raiva' são transmitidos metaforicamente ao experienciador.

Esses exemplos, em que o evento é concebido como causado externamente, ilustram, na perspectiva defendida nesta tese, a porção do evento bidirecional de Croft (1993) em que o estímulo causa a emoção no experienciador.

No entanto, como foi dito, eventos experienciais são conceitualizados como bidirecionais, dessa forma, não há uma única direção conceitual em que esses eventos podem ser concebidos.

Experienciadores, como Dowty (1991) já notava, têm características de agente, i.e., são participantes particularmente salientes na medida em que são animados e sencientes. Com isso, algumas consequências conceituais são esperadas, esses participantes podem ocorrer sozinhos, sem o estímulo; e são frequentemente conceitualizados como o 'local' onde a emoção acontece ou se dá e, por isso, são

\footnotetext{
${ }^{53}$ Fontes correspondentes a cada exemplo, respectivamente: https://books.google.com.br/books?id=PSdTBQAAQBAJ ultimosegundo.ig.com.br/ https://brasil.babycenter.com/thread/3481644/irrita\%C3\%A7\%C3\%A3o-e-raiva\#ixzz51TWP4tl2 https://brasil.babycenter.com/thread/3481644/irrita\%C3\%A7\%C3\%A3o-e-raiva\#ixzz51VsFhmpE blog.chicomaia.com.br
} 
frequentemente conceitualizados como a fonte de energia daquele evento emocional (como em construções SubjExp e incoativas).

Um indício dessa forma de se conceitualizar o experienciador, isto é, como 'locais', o 'container' da emoção, são as perífrases encontradas com esses verbos (como em (34) abaixo), indicando o frequente uso de metáforas espaciais. ${ }^{54}$

(34) a. Havia um medo no governo também de que os reajustes salariais poderiam acelerar ainda mais o aumento dos preços

b. [...] para a maioria das pessoas, a menção apenas da morte já traz medo: medo do desconhecido, medo da separação das pessoas

c. Ah, sim, você e eu estamos cheios de medo e medos... Eu tenho tantos que nem sei de alguns.

d. Depois de pintadas me veio um medo terrível de errar na combinação das flores

e. O dano causado por esta forma de abuso habita em nossa memória, fere a nossa personalidade, que semeia o ódio em nossos corações, que reduz a nossa auto-estima, e isso nos enche de medo.

(Dados retirados do Google ${ }^{55}$ )

Os exemplos em (34) possuem todos a palavra 'medo' e, apesar de constituírem expressões distintas para descrever o evento emocional, têm em comum a presença de metáforas espaciais, seja o experienciador na forma de alvo, em que o medo vai ou é

\footnotetext{
${ }^{54}$ Arad (1998) faz uma distinção entre verbos ObjExp incorporados e não incorporados citando exemplos do francês e inglês. Os primeiros seriam formas como enrager 'enraivecer' e attrister 'entristecer' do francês e gladden 'alegrar-se' e sadden 'entristecer' do inglês. Os segundos, a autora divide entre locativos como mettre en colère 'lit: pôr em raiva'; dativos como give a headache 'dar uma dor de cabeça'; e causativos como faire peur 'dar medo', make/turn angry/sad 'ficar com raiva/triste'.

${ }^{55}$ Fontes correspondentes a cada exemplo, respectivamente:

http://2012umnovodespertar.blogspot.com/2011/09/brasil-esta-bem-quem-disse-que-crise.html http://24.229.2.221/sermoes/296.html http://blogdoamstalden.com/2012/08/28/medo-e-coragem-por-luis-fernando-amstalden/ http://casandosemgrana.com.br/tag/doces/ http://vozesmormons.com.br/2013/04/07/sessao-de-domingo-da-tarde-ao-vivo/
} 
trazido até ele (34b, d), seja na forma de um container que é preenchido pelo medo (32c, e), ou seja na forma de local (34a) onde existe a emoção.

Como foi dito, devido à saliência conceitual do experienciador, é esperado encontrarmos nas línguas construções em que o experienciador seja conceitualizado como o participante mais proeminente, sendo o ponto de acesso mental daquele evento emocional.

Os exemplos em (35) ilustram diferentes momentos durante o discurso em que os falantes usam construções ObjExp e SubjExp. É interessante observar esses exemplos também em contraste com os exemplos em (32):

(35) a. [...] Pois bem, ontem ela passou o dia chorosa, nada acalmava ela, e no final da noite, tentando acalmar ela enquanto a minha esposa tomava um banho, ela chorava de soluçar no meu colo. Ja estava meio irritado pois passamos o dia a base do choro, e naquele momento a minha esposa ja tinha saido do banho, entreguei a minha pequena para ela, e naquele momento estava MUITO irritado com a minha pequena, a ponto de ficar com raiva dela e nao querer mais pegar ela naquele momento.

Depois que fui dormir, fiquei muito chateado comigo mesmo por ter esse sentimento tao ruim, ainda mais direcionado a minha filha! Gostaria de nao ter sentido, mas senti!

b. Então as pessoas estavam nervosas. Eu estava nervoso. E lembro que depois de seu primeiro take, ele veio até mim e disse 'Isso vai ser divertido'.

c. já cansei de tanto ir em ortopedista, fiz aculputura e nada resolve. gostaria de saber se um fisiatra seria o mais indicado para meu caso...

d. a gente aprende só na prática mesmo, e quanto mais vão crescendo, por mais fases vão passando e mais paciência a gente aprende a ter rss me lembrei de uma coisa!!! Um objeto que me ajudou muito muito mesmo, foi um móbile que tocava musiquinha

e. Eu me diverti fazendo esse filme. Não preciso que o público necessariamente gargalhe.

(Dados retirados do Google ${ }^{56}$ )

\footnotetext{
${ }^{56}$ Fontes correspondentes a cada exemplo, respectivamente: https://brasil.babycenter.com/thread/3481644/ http://www.popdebotequim.com/2013/07/criador-de-glee-fala-sobre-morte-de.html http://adoratual.wordpress.com/o-que-e-um-medico-fisiatra/
} 
Em (35a), o falante começa descrevendo uma situação em que não conseguia fazer o bebê se acalmar, apesar de suas tentativas. Para isso, usa uma construção ObjExp com o verbo 'acalmar' duas vezes. Em seguida, começa a descrever seu próprio estado emocional, é interessante notar que o falante vai aumentando o grau de intensidade da emoção (no caso, de irritação), começando por 'meio' e depois 'muito' e culminando em 'ficar com raiva'. Dessas três vezes, em duas, o falante, por meio de adjuntos 'com ela' e 'dela', expressa de forma explícita o estímulo. E em uma, não menciona o estímulo, apenas descrevendo o estado emocional.

No próximo trecho, o falante dirige a si mesmo o estado emocional de 'chatearse', expressando o arrependimento e um sentimento de não ter tido controle sobre suas emoções. É interessante que o falante menciona o sentimento como dirigido à filha, metaforicamente o alvo da emoção.

Em (35b), o falante narra o estado emocional de nervosismo sentido por ele e por outras pessoas, além de descrever sua lembrança (usando uma construção SubjExp com o verbo lembrar). Em seguida, cita a fala de outro que coloca maior saliência no estímulo, retomado contextualmente pelo demonstrativo 'isso'.

Em (35c), em contraste com (32c, e), o verbo 'cansar' é usado em uma construção com o experienciador como sujeito em que o falante descreve seu estado emocional.

Em (35d), como em (35b), o verbo 'lembrar' é também usado em uma construção com o experienciador como sujeito, denotando o surgimento espontâneo da lembrança no experienciador e não seu aspecto causal como em (32b).

Em (35e), a ênfase maior está no experienciador e no que sentiu ao realizar um determinado evento (o filme).

Assim como vimos em relação às construções com ObjExp, há diversas e distintas construções que podem ser realizadas com o experienciador como foco primário em português. Dentre elas, construções médias (lembrar-se, cansar-se, divertirse), construções com os verbos 'estar' (estar irritado), 'ficar' (ficar com raiva), 'ter' (ter medo), construções com dois argumentos (amar, invejar). 
Com exceção de construções consideradas mais transitivas com dois participantes (amar, invejar), as outras parecem ocorrer livremente sem o estímulo, e quando ele é realizado, aparece nessas construções por meio de preposições, de forma mais periférica (ter medo de, estar com raiva de, ficar preocupado com, lembrar-se de, cansar-se de, divertir-se com). ${ }^{57}$

De fato, essas construções, comparadas a construções com dois participantes como 'amar', são mais intransitivas, o que, a princípio, parece salientar a porção em que a emoção surge e ocorre nele próprio, podendo, opcionalmente, ser dirigida ao estímulo.

Parece-nos que esse fator está relacionado ao uso de construções médias com verbos de emoção, já que nessas construções o ponto de início e o ponto final do evento é o mesmo participante (cf. Kemmer, 1993). ${ }^{58}$

Como já notado na literatura (cf. Grafmiller (2013) e Croft (1993)), eventos emocionais têm uma propriedade inerente que é 'object-directedness', a propensão a dirigir a emoção a alguma coisa, i.e., o experienciador dirige sua atenção a determinado estímulo. Propriedade que parece salientar o aspecto bidirecional dos eventos experienciais.

Por essa razão, há sempre a possibilidade de codificar o estímulo por meio de preposições nas construções observadas acima, inclusive nas médias.

Naturalmente, há outros fatores, além da maior saliência conceitual do experienciador, que distinguem e interferem na escolha de cada uma dessas construções com o experienciador como foco primário. Uma delas é aspectual, envolvendo incoatividade (apaixonar-se, entristecer-se), o estado resultativo (com o verbo 'ficar') e estatividade (verbos 'estar' e 'ter' e verbos com dois participantes como 'amar').

Um outro dado do português que evidencia a importância característica bidirecional apontada por Croft (1993) dos eventos emocionais é o uso de preposições com substantivos denotando emoções em construções com o verbo 'ter' e 'sentir'. Observe as sentenças a seguir:

\footnotetext{
57 Diz-se periférico, nos termos da Gramática Cognitiva de Langacker (2008), quando um nominal é introduzido perifrasticamente por meio de uma relação codificada separadamente, indicando, assim, que o envolvimento daquele nominal é mais periférico em relação a nominais introduzidos diretamente como argumentos do verbo.

58 Para Kemmer (1993), considerando transitividade como uma noção escalar, as construções médias estariam entre construções transitivas (máxima distinguibilidade entre dois participantes) e intransitivas com um participante. Em uma construção média, os papéis de iniciador (initiator) e ponto final (endpoint) se referem ao mesmo participante e não haveria distinguibilidade conceitual desse participante como há nas construções reflexivas, aproximando-as do espectro das construções intransitivas.
} 
(36) a. O João tem/sente medo de cobra.

b. O João tem/sente raiva de cobra.

c. O João tem/sente ódio de cobra.

d. O João tem/sente nojo de cobra.

e. O João tem/sente inveja do Pedro.

f. O João tem/(sente?) receio de cobra.

g. O João tem/sente vergonha do Pedro.

Em todos os exemplos acima, as emoções podem ser tidas como mais 'negativas' ou, pelo menos, não muito agradáveis de se sentir. Já nos exemplos em (37) abaixo, as emoções tendem a ser mais positivas ou que mostram um certo grau de zelo ou empatia pelo estímulo:

(37) a. O João tem/sente amor por animais.

b. O João tem/sente desejo por mulheres.

c. O João tem gosto por animais.

d. O João tem/sente admiração por mulheres.

e. O João tem/sente apreço pelo Pedro.

f. O João tem/sente receio pelo filho.

g. O João sente vergonha pelo Pedro.

Em contraste com (36f, g), (37f, g) mostra um sentimento de maior empatia ou zelo pelo estímulo. Além do contraste entre emoções mais positivas e negativas, há a diferença entre o uso das preposições, em (36), a preposição usada é 'de', em (37), 'por'.

Parece-nos que o uso diferenciado das preposições nessas construções indica caminhos conceituais distintos. As construções com a preposição 'de' parecem enfatizar a qualidade do estímulo como responsável pela emoção causada no experienciador, 
talvez por serem emoções vistas como mais 'negativas'. Já as construções com 'por' parecem enfatizar a emoção como a surgir do experienciador em direção ao estímulo, i.e., em que ele dirige aquela emoção ao estímulo, sendo emoções mais positivas ou que mostram empatia em relação ao estímulo.

Os dados do português acima em (36) e (37) serão retomados na seção 5.4 e também no capítulo 7 quando discutiremos a nossa hipótese acerca da conceitualização bidirecional de eventos experienciais. 


\section{INTRODUÇÃO À GRAMÁTICA DO GEORGIANO}

\subsection{Introdução}

Faremos nesta seção uma revisão breve de aspectos básicos da gramática do georgiano, principalmente do ponto de vista da literatura gramatical referencial da língua. Dessa forma, o intuito é introduzir ao leitor a descrição usual da língua e familiarizá-lo com o sistema verbal georgiano que é particularmente complexo.

Um ponto importante a ser destacado é que, ao longo do trabalho, quando nos referirmos às classes verbais tradicionais do georgiano 'Classe I, Classe II, Classe III e Classe IV' estaremos fazendo alusão essencialmente às características morfossintáticas comuns entre os verbos de determinada classe tal como usualmente divisadas na literatura. Essa referência às classes facilitará a retomada de padrões de concordância e de marcação de caso.

A visão que adotamos neste trabalho, no entanto, não parte de uma visão categórica de classes verbais com limites bem definidos como se assume nas gramáticas tradicionais. Para ilustrar, tomemos os verbos chamados de Classe IV (a classe que abarca a maior parte de verbos experienciais com o experienciador no dativo). Apesar de esse agrupamento ser um importante ponto de partida, não é absoluto, pois se adotássemos uma visão restrita de classe, muitos outros verbos (de outras classes verbais, mas que também apresentam um participante dativo potencialmente como foco primário) ficariam de fora de nossa descrição por não apresentarem determinadas características morfológicas de Classe IV. Em termos de significação, no entanto, i.e, do significado dessas construções, é possível observar que eles fazem parte do mesmo fenômeno conceitual global estudado.

\subsection{As classes verbais na gramática tradicional}

$\mathrm{Na}$ literatura gramatical tradicional da língua e na literatura linguística em que a descrição do georgiano se assenta, dividem-se os verbos em georgiano em 'classes', representando propriedades comuns entre os verbos de cada classe. Apesar de os rótulos 
mudarem dependendo do autor, as classificações são basicamente similares nas distinções e limites que propõem, principalmente em relação a critérios morfológicos.

No entanto, em relação às propriedades semânticas e sintáticas atribuídas a cada classe, nem sempre há consenso. Os parâmetros por vezes empregados para distinguir entre uma classe e outra, além de suas características morfológicas, variam entre voz, transitividade ou ambos. Na gramática tradicional de Shanidze (1973), classificam-se os verbos em ativos, passivos e médios, estes últimos subdivididos em médio ativos e médio passivos. Hewitt (1995) agrupa os verbos em transitivos, intransitivos, mediais, indiretos e estativos. De forma similar, Tschenkeli (1958) separa os verbos em transitivos, médios, passivos e indiretos. Aronson (1990) faz uma classificação de verbos em quatro conjugações que se assemelha à distinção feita por Tschenkeli. Harris (1981), por sua vez, também divide os verbos em quatro classes, definindo-as inicialmente apenas com base em distinções morfológicas diretas.

Como mencionado, o principal problema inerente a esse tipo de classificação e terminologia, e frequentemente notado pelos autores, é a não uniformidade entre os verbos de cada classe em relação às suas características sintáticas e semânticas (cf. AMIRIDZE, 2006; HEWITT, 1995; TUITE, 1998, 2006).

Harris (1981), por exemplo, ainda que parta de uma definição formal dessas classes, argumenta que podem ser identificadas características semânticas e sintáticas comuns a cada classe, tornando-as não arbitrárias.

Apesar de ser uma questão controversa na literatura (cf. HEWITT, 1983, 1987a, 1987b), a autora argumenta que, levando em consideração similaridades semânticas e sintáticas em cada classe, a língua apresentaria uma marcação ativo-estativa, i.e., verbos intransitivos têm uma marcação distinta a depender do grau de agentividade ou controle do sujeito sobre a ação. Verbos intransitivos que denotam ações menos agentivas têm seu sujeito marcado da mesma forma que objetos diretos de verbos transitivos, enquanto verbos intransitivos que denotam ações mais agentivas e controláveis têm seus sujeitos marcados da mesma forma que sujeitos de verbos transitivos.

A partir dessa premissa, a autora traça as seguintes generalizações: a Classe I seria composta em sua maioria por verbos transitivos e ativos; a Classe II seria formada por verbos intransitivos com sujeitos marcados da mesma forma que objetos diretos de transitivos de Classe I, caracterizados por uma semântica inativa ou passiva; a Classe III seria composta por verbos intransitivos com sujeitos marcados da mesma forma que sujeitos de verbos transitivos de Classe I, sendo caracterizados por uma semântica ativa 
ou agentiva; a Classe IV, por fim, seria formada por verbos indiretos, apresentando sujeitos caracterizados por serem experienciadores e de pouco controle sobre a ação.

$\mathrm{Na}$ análise de Holisky (1981), a distinção entre duas classes de intransitivos em georgiano não se daria em termos de agentividade, mas sim em termos de aspecto lexical, enquanto a Classe II compreenderia verbos incoativos télicos e de mudança de estado, a Classe III compreenderia verbos de atividades atélicas, ou seja, ações que não seriam dirigidas a um ponto final. ${ }^{59}$ Já a Classe IV seria formada por verbos estativos e que seriam durativos aspectualmente, enquanto a Classe I seria, na maior parte, composta por verbos télicos (cf. CHERCHI, 1997).

A seguir, serão então revistos alguns aspectos do sistema verbal, além da classificação dos verbos em classes mencionada acima, a partir da visão tradicional em que se assenta a descrição gramatical da língua.

\subsection{Classes: marcação de caso e concordância em georgiano}

\subsubsection{Marcação de caso}

Uma visão geral da marcação de caso em georgiano pode ser vista na Tabela 3. Os padrões de marcação de caso variam de acordo com a classe do verbo e com a Série, termo proveniente do georgiano e que agrupa um conjunto de diferentes screeves termo também adaptado do georgiano, ' $m c$ 'k'rivi', constituindo paradigmas de formas verbais flexionadas em número e pessoa e que refletem, morfologicamente, uma formação de radical em comum e, sintaticamente, um padrão de marcação de caso em comum (TUITE, 1998; WIER, 2008).

\footnotetext{
${ }^{59} \mathrm{~A}$ análise da autora gira em torno dos verbos que chama de 'mediais', compreendidos pela Classe III acima citada. A partir do estabelecimento de critérios morfológicos para delimitar a classe e da comparação com as outras classes de verbos, a autora, analisando as propriedades semânticas de seus membros, chega à conclusão da importância do aspecto lexical para a caracterização desses verbos e para sua distinção em relação às demais classes.
} 


\begin{tabular}{|c|c|c|c|c|c|c|c|c|c|}
\hline & \multicolumn{3}{|c|}{ Séries I - Presente } & \multicolumn{3}{c|}{ Séries II - Aoristo } & \multicolumn{3}{c|}{ Séries III - Perfeito } \\
\hline & SUJ & OD & OI & SUJ & OD & OI & SUJ & OD & OI \\
\hline Classe I & NOM & DAT & DAT & ERG & NOM & DAT & DAT & NOM & OBL \\
\hline Classe II & NOM & - & DAT & NOM & - & DAT & NOM & - & DAT \\
\hline Classe III & NOM & (DAT) & DAT & ERG & (NOM) & DAT & DAT & (NOM) & OBL \\
\hline Classe IV & DAT & NOM & (OBL) & DAT & NOM & (OBL) & DAT & NOM & (OBL) \\
\hline
\end{tabular}

Tabela 3: Marcação de caso de acordo com a classe e série.

Como pode ser observado pela Tabela 3, não há uma correlação única entre os casos e relações gramaticais. Casos, por exemplo, como o nominativo e dativo podem marcar tanto sujeitos quanto objetos dependendo da classe do verbo e de características aspectuais e temporais expressas pelo verbo (AMIRIDZE, 2006).

Nas Séries I do Presente, o sujeito é marcado pelo nominativo e o objeto pelo dativo, nas Séries III do Perfeito e com os verbos de Classe IV em todas as Séries, há o que chamam de inversão, o objeto passa a ser marcado pelo nominativo e o sujeito pelo dativo.

A Tabela 4, a seguir, ilustra a divisão de cada Série em screeves, as Séries I do Presente sendo subdivididas em duas subséries, do presente e do futuro:

\begin{tabular}{|c|c|c|}
\hline \multirow{2}{*}{ Séries I - Presente } & \multicolumn{2}{|c|}{ Screeve } \\
\cline { 2 - 3 } & Subsérie do Presente & Subsérie do Futuro \\
\cline { 2 - 3 } & Presente & Futuro \\
\cline { 2 - 3 } & Subjuntivo Presente & Condicional \\
\hline \multirow{2}{*}{ Séries II - Aoristo } & \multicolumn{2}{|c|}{ Aoristo } \\
\hline \multirow{2}{*}{ Séries III - Perfeito } & \multicolumn{2}{|c|}{ Optativo } \\
\cline { 2 - 3 } & \multicolumn{2}{|c|}{ Perfeito } \\
\cline { 2 - 3 } & \multicolumn{2}{|c|}{ Mais-que-perfeito } \\
\hline
\end{tabular}

Tabela 4: Sistema de screeves.

A ergatividade cindida no georgiano - para aqueles a favor da tese de que a língua apresentaria padrões de ergatividade -, teria sua manifestação nas Séries II do Aoristo: verbos de Classe I, na maioria transitivos, têm o sujeito marcado pelo caso ergativo e o objeto pelo caso nominativo, enquanto verbos de Classe II, normalmente 
intransitivos, têm seu sujeito marcado com o caso nominativo, mesmo caso usado para marcar o objeto de verbos de Classe I nas Séries II.

Dessa forma, além dos casos de inversão que afetam tanto a marcação de caso quanto a concordância, o padrão de caso nas Séries II também altera os valores entre caso e relações gramaticais, o caso nominativo, por exemplo, que marcava nas Séries I o sujeito de verbos transitivos e intransitivos, passa a marcar nas Séries II o objeto de transitivos e sujeito de intransitivos de Classe II (mas não de Classe III).

\subsubsection{Concordância}

A estrutura do verbo em georgiano é morfologicamente complexa. O verbo concorda com o sujeito, o objeto direto e em alguns casos com o objeto indireto, além de carregar marcas de aspecto, tempo, passividade, causatividade, dentre outras.

Basicamente, a estrutura morfológica que pode compor um verbo em georgiano pode ser visualizada na Tabela 5. Cada posição indicada por um número representa o que se chama de slots que, presentes na estrutura de um dado verbo, possuem uma posição fixa antes ou depois da raiz verbal como indicado.

\begin{tabular}{|c|c|c|c|c|c|c|c|}
\hline 1 & 2 & 3 & 4 & 5 & 6 & 7 & 8 \\
\hline Preverbo & $\begin{array}{c}\text { Prefixo de } \\
\text { Concordância }\end{array}$ & $\begin{array}{c}\text { Vogal Pré- } \\
\text { Radical }\end{array}$ & RAIZ & $\begin{array}{c}\text { Sufixo } \\
\text { Incoativo }\end{array}$ & $\begin{array}{c}\text { Sufixo } \\
\text { Temático }\end{array}$ & $\begin{array}{c}\text { Marca de } \\
\text { Tempo/Modo }\end{array}$ & $\begin{array}{c}\text { Sufixo de } \\
\text { Concordância }\end{array}$ \\
\hline
\end{tabular}

Nos slots número 2 e 8 aparecem os afixos responsáveis pela concordância. É por meio de uma combinação de prefixos e sufixos que se dá a concordância com sujeito e objeto.

A distribuição dos conjuntos de afixos vai depender da estrutura argumental do verbo, da classe verbal, de características aspectuais e temporais do verbo e por vezes é idiossincrática ao verbo (AMIRIDZE, 2006). 
A Tabela 6 mostra os afixos de concordância em georgiano. Para evitar denominar os dois conjuntos de marcas de 'sujeito' e 'objeto' respectivamente identificação, aliás, feita em alguns trabalhos - optou-se por seguir Amiridze (2006) e apenas identificar os conjuntos de afixos como A e B. O principal motivo, como ficará evidente, é que os afixos, tanto de um conjunto quanto de outro, não são usados exclusivamente para marcar sujeito e objeto respectivamente.

\begin{tabular}{|c|c|c|}
\hline \multicolumn{3}{|c|}{ Conjunto A } \\
\hline & Singular & Plural \\
\hline $1^{\mathrm{a}}$ pessoa & $\mathrm{v}-$ & $\mathrm{v}-\mathrm{t}$ \\
\hline $2^{\mathrm{a}}$ pessoa & $\varnothing$ & $-\mathrm{t}$ \\
\hline $3^{\mathrm{a}}$ pessoa & $-\mathrm{s} / \mathrm{a} / \mathrm{o}$ & -en/es/nen, etc \\
\hline
\end{tabular}

\begin{tabular}{|c|c|c|}
\hline \multicolumn{3}{|c|}{ Conjunto B } \\
\hline & Singular & Plural \\
\hline $1^{\text {a }}$ pessoa & m- & gv- \\
\hline $2^{\text {a }}$ pessoa & g- & g-t \\
\hline $3^{\text {a }}$ pessoa & $\mathrm{s} / \mathrm{h} / \varnothing-$ & $\mathrm{s} / \mathrm{h} / \varnothing-\mathrm{t}$ \\
\hline
\end{tabular}

Tabela 6: Afixos de Concordância

A alternância entre as marcas de terceira pessoa do conjunto A é determinada por tempo/aspecto e classe do verbo.

$\mathrm{O}$ conjunto $\mathrm{B}$ engloba os afixos que usualmente marcariam tanto o objeto direto quanto o indireto. A única diferença entre as marcas de concordância de objeto direto e indireto no verbo estaria na terceira pessoa do singular e plural, em que o objeto direto teria uma marca zero para singular e plural, enquanto que o objeto indireto teria, para plural e singular, além da marca zero, duas outras marcas que se alternariam $(-s /-h)$, sendo fonologicamente previsíveis.

No entanto, no georgiano moderno, essas marcas de objeto indireto $(-s /-h)$ não são mais usadas consistentemente (cf. HARRIS, 1981; HEWITT, 1995), apagando essa diferença entre as marcas de concordância de objeto direto e indireto no verbo. Por esse motivo, não se costuma representar em dois conjuntos distintos as marcas de objeto direto e indireto.

A inversão que ocorre em verbos de Classe IV e nas Séries III do perfeito em verbos de Classe I e III também se reflete na concordância. Os afixos do conjunto A que marcam o sujeito nas Séries I, nas Séries III e em verbos de Classe IV, passam a marcar o objeto, enquanto os afixos do conjunto B passam a marcar o sujeito nas Séries III e em verbos de Classe IV. Por essa razão, é preferível denominar os conjuntos de afixos apenas como A e B, e não como afixos de sujeito e objeto respectivamente. 
O aparente padrão de ergatividade observado nas Séries II - diferente dos casos de inversão em que tanto a marcação de caso quanto a concordância são afetadas - se refletiria apenas na marcação de caso e não na concordância, i.e., tanto sujeitos de transitivos quanto de intransitivos acionam os afixos do conjunto A nas Séries I e Séries II, enquanto o objeto de transitivos aciona os afixos do conjunto B.

\subsection{As classes}

\subsubsection{Classe I}

Morfologicamente, verbos de Classe I são caracterizados pelas seguintes propriedades (cf. HARRIS, 1981 e HOLISKY, 1979): adição de um preverbo no tempo futuro - distinguindo-o do presente - e no aoristo (observe a presença do preverbo $a$ - na sentença em (38b) no aoristo das Séries II); o afixo de concordância $-s$ é utilizado para marcar, no verbo, o sujeito na terceira pessoa do singular (cf. $a$-shen-eb-s 'ele constrói') e o afixo -en para marcar, no verbo, o sujeito na terceira pessoa do plural no futuro e presente (observe a sentença em (38a) no presente); no aoristo, o afixo de concordância -es marca o sujeito na terceira pessoa do plural no verbo (observe a sentença em (38b)):
a. kal-eb-i
saxl-s
a-shen-eb-en
mulher-PL-NOM
casa-DAT
VPR-construir-ST-3ANOM.PL ${ }^{60}$
As mulheres estão construindo uma casa.
b. kal-eb-ma saxl-i a-a-shen-es
mulher-PL-ERG casa-NOM PV-VPR-construir-3AERG.PL.AOR
As mulheres construíram a casa.
c. kal-eb-s turme saxl-i a-u-shen-eb-i-a-t
mulher-PL-DAT aparentemente casa-NOM PV-VPR-construir-ST-SM-3ANOM-PL As mulheres aparentemente construíram a casa.

\footnotetext{
${ }^{60}$ As glosas usadas no presente trabalho referentes aos exemplos do georgiano, o que inclui a forma de identificar e separar os morfemas, foram adaptadas dos trabalhos de Amiridze (2006) e Hillery (2009).
} 
Ademais, verbos de Classe I seguem os padrões de marcação observados na Tabela 3, i.e., têm seu sujeito marcado pelo caso ergativo nas Séries II do Aoristo e sofrem inversão na marcação de caso e concordância nas Séries III do Perfeito.

Dentre os verbos que poderiam ser considerados prototípicos de Classe I - i.e., verbos que usualmente denotam eventos de dois ou mais participantes com sujeitos agentivos, agindo volitivamente - , encontram-se verbos transitivos como o exemplificado acima $a$-shen-eb-s 'construir' formado, como é característico de alguns verbos dessa classe, com a vogal pré-radical - $a$-, ou 'versão neutra' como é chamada, e com o sufixo temático -eb-; verbos ditransitivos como $a$-chuk-eb-s 'dar algo a alguém', com um objeto direto e um objeto indireto, têm este último no dativo nas Séries I e II, e nas Séries III, sendo marcado por uma posposição; e verbos causativos como $a$-shen-ebin-eb-s 'fazer alguém construir alguma coisa' formado pelo afixo causativo -in-, em adição ao sufixo temático $-e b$ - e à vogal pré-radical $-a-{ }^{61}$

\subsubsection{Classe II}

As características morfológicas usualmente atribuídas a verbos de Classe II são: a formação, assim como verbos de Classe I, do futuro das Séries I e do aoristo das Séries II por meio de um preverbo (ver (39b)); o afixo de concordância - $a$ é usado para marcar, no verbo, o sujeito na terceira pessoa do singular (observe a sentença em (39a)) e o afixo -en para marcar, no verbo, o sujeito na terceira pessoa do plural no futuro e presente; no aoristo das Séries II, o afixo de concordância -en também marca, no verbo, o sujeito na terceira pessoa do plural (HARRIS, 1981; HOLISKY, 1979).

Como mostrado na Tabela 3, diferente de verbos de Classe I, verbos de Classe II têm seu sujeito marcado com o caso nominativo em todas as Séries e não sofrem inversão nas Séries III do Perfeito.

\footnotetext{
${ }^{61}$ Como se costuma fazer em alguns dicionários da língua georgiana e feito neste trabalho, a forma de citação do verbo é na terceira pessoa do singular no presente, por exemplo, a-shen-eb-s 'ele constrói', sendo traduzida pelo infinitivo em português quando em forma de citação do verbo.
} 
Os exemplos abaixo ilustram um verbo prototípico de Classe II t'qd-eb-a 'quebrar', denotando um evento de um participante e com um sujeito considerado tema, inanimado e não agentivo.
a. k'alam-i
qoveltvis
t'qd-eb-a
caneta-NOM
sempre
quebrar-ST-3ANOM

A caneta está sempre quebrando.

$\begin{array}{lll}\text { b. } & \text { k'alam-i } & \text { ga-t'qd-a } \\ \text { caneta-NOM } & \text { PV-quebrar-3ANOM.AOR } & \text { gushin } \\ & \text { ontem }\end{array}$

A caneta quebrou ontem.
c. k'alam-i turme ga-t'exil-a
caneta-NOM aparentemente PV-quebrar-3ANOM

A caneta aparentemente quebrou.

Verbos de Classe II são tradicionalmente subdivididos em três tipos: verbos passivos prefixais, formados com a vogal pré-radical - $i$-, como, por exemplo, o verbo de sentido passivo na sentença c'eril-i $i$-c'er-eb-a, 'a carta está sendo escrita', derivado do verbo de Classe I c'er-s 'escrever'; verbos sufixais, formados a partir da adição do infixo - $d$ - no slot 5 (ver Tabela 4) junto à raiz, sendo que vários desses verbos sufixais são derivados de adjetivos e substantivos, carregando um sentindo incoativo de 'tornarse alguma coisa', como, por exemplo, c'itl- $d$-eb-a 'tornar-se vermelho, corar' derivado de c'iteli 'vermelho'; e verbos sem marca (ou radicais), constituindo formas verbais básicas da classe, i.e., não derivadas, como, por exemplo, $k$ 'vd-eb-a 'morrer'.

Os verbos em georgiano tradicionalmente chamados de 'passivos de estado' são também agrupados por alguns na Classe II (cf. HARRIS, 1981) - já outros autores preferem agrupá-los em classe separada (cf. HEWITT, 1995). Esses verbos constituem

\footnotetext{
62 O morfema - $a$, observado em sentenças no aoristo como (39b), é uma marca de screeve (SM) que varia de acordo com o verbo, pessoa e segue, a depender da classe, o padrão 'fraco' ou 'forte', sendo sempre glosado com a pessoa e caso a que se refere e com a indicação AOR. Esse morfema, como marca de screeve, não é equivalente ao morfema - $a$ presente no último slot em (39a) e (39c) que constitui apenas marca de pessoa.
} 
um grupo restrito de verbos de semântica estativa como, por exemplo, o verbo a-par-ia ‘estar espalhado, coberto', ilustrado a seguir pelo exemplo retirado de Harris (1981):

$\begin{array}{llll}\text { (40) a. } & \text { mt'ver-i } & \text { a-par-i-a } & \text { iat'ak'-ze } \\ & \text { poeira-NOM } & \text { VPR-estar.espalhado-ST-3ANOM } & \text { chão-POSP } \\ & \text { A poeira está espalhada no chão. } & \end{array}$

\subsubsection{Classe III}

As propriedades morfológicas levantadas na caracterização de verbos de Classe III podem ser resumidas às seguintes: tanto o futuro quanto o aoristo são formados através da adição da vogal pré-radical $-i$ - (observe a sentença no aoristo em (41b) e o futuro do verbo 'jogar' $v$-i-tamash-eb, 'eu jogarei'); o afixo de concordância $-s$ é utilizado para marcar, no verbo, o sujeito na terceira pessoa do singular (note a sentença no singular em (41a) no tempo presente) e o afixo -en para marcar, no verbo, o sujeito na terceira pessoa do plural no futuro e presente; no aoristo, o afixo de concordância -es marca o sujeito na terceira pessoa do plural (ver sentença (41b)).

$$
\begin{aligned}
& \text { a. k'ac-i musha-ob-s qoveldghe } \\
& \text { homem-NOM trabalhar-ST-3ANOM todo.dia }
\end{aligned}
$$
b. k'ac-eb-ma i-mushav-es qoveldghe homem-PL-ERG VPR-trabalhar-3AERG.PL.AOR todo.dia Os homens trabalharam.
c. k'ac-eb-s turme u-mushav-i-a-t homem-PL-DAT aparentemente VPR-trabalhar-SM-3ANOM-PL
Os homens aparentemente trabalharam.


Assim como verbos de Classe I, verbos de Classe III sofrem inversão nas Séries III, como pode ser observado na sentença (41c) em que o sujeito é marcado com o caso dativo. Nas Séries II do Aoristo, também da mesma forma que verbos de Classe I, verbos de Classe III têm o sujeito marcado com o caso ergativo.

Ainda que a classificação tradicional considere a Classe III como aquela que engloba verbos intransitivos agentivos, podem-se encontrar, nessa classe, além de verbos de um participante com sujeitos agentivos, também eventos com dois participantes. Dentre as formas verbais básicas de Classe III há aqueles de um participante como $i$-cin- $i$-s 'rir' e qvir-i-s 'gritar', e aqueles que podem tomar um segundo participante opcionalmente como tamash-ob-s 'jogar, brincar'. O verbo ilustrado acima musha-ob-s 'trabalhar' exemplifica os verbos denominais da classe. Um terceiro tipo de verbos característicos de Classe III são alguns verbos que expressam eventos durativos tais como dugh-s 'ferver', prial-eb-s 'brilhar', etc.

Holisky (1980) descreve verbos de Classe III como verbos de aspecto inerentemente durativo e que expressam eventos dinâmicos. Para a autora, a base da distinção entre certos verbos intransitivos de Classe II e III é aspectual, enquanto verbos de Classe III como t'ir-i-s 'chorar' e dugh-s 'ferver' constituem atividades em andamento e, por isso, são considerados atélicos, i.e., sem indicar início ou término da ação, os verbos correspondentes de Classe II sufixais $t$ 'ir- $d$-eb-a 'começar a chorar' e dugh-d-eb-a 'começar a ferver' são télicos incoativos (ARONSON, 1990; HOLISKY, 1981; TUITE, 1998).

\subsubsection{Classe IV}

A verbos de Classe IV são usualmente atribuídas as seguintes características morfológicas: a formação do futuro e do aoristo é feita através da vogal pré-radical -e-, observe (42b) no futuro, assemelhando-se a verbos de Classe III que formam esses tempos sem preverbos; no futuro, o afixo - $a$ marca sujeitos na terceira pessoa do singular (cf. (42b)) (HARRIS, 1981; HOLISKY, 1979). 
Verbos de Classe IV também apresentam a peculiaridade de sofrerem inversão em todas as séries, como pode ser observado pela Tabela 3 .
a. bich'-eb-s
u-qvar-t
gogona
garoto-PL-DAT VPR-amar-PL
menina.NOM

Os garotos amam a menina.

$\begin{array}{llll}\text { b. } & \text { bich'-eb-s } & \text { e-qvar-eb-a-t } & \text { gogona } \\ \text { garoto-PL-DAT } & \text { VPR-amar-ST-3ANOM-PL } & \text { menina.NOM }\end{array}$

Os garotos amarão a menina ${ }^{63}$
c. bich'-eb-s
qvar-eb-i-a-t
gogona
garoto-PL-DAT amar-ST-SM-3ANOM-PL
menina.NOM

Os garotos aparentemente amaram a menina.

As sentenças em (42) ilustram um verbo prototípico de Classe IV u-qvar-s 'amar'. De modo geral, verbos de Classe IV expressam sensações involuntárias, sintomas, emoções, estados (mentais, físicos), etc. Essa semântica peculiar da classe correlaciona-se com o caráter de seus sujeitos, considerados típicos experienciadores.

Outros exemplos de verbos característicos da classe são $d z u l-s$ 'odiar', c'qur-ia 'ter sede' e a-xsov-s 'lembrar-se'. Nessa classe, a depender do autor, são por vezes incluídos os chamados verbos de humor, ou desiderativos, que expressam vontade ou desejo de fazer algo, por exemplo, $e$-mgher-eb-a 'sentir desejo de cantar' ${ }^{64}$

\footnotetext{
${ }^{63}$ A forma no aoristo do verbo $u$-qvar-s 'amar' não é comum, por isso optou-se por usar, neste caso, um exemplo no tempo futuro.

${ }^{64}$ Ainda que boa parte dos verbos indiretos apresente um segundo participante no caso nominativo, denotando o estímulo (como o exemplo acima do verbo 'amar') ou a coisa experienciada, percebida ou possuída, muitos não apresentam tal nominal, como é o caso de $s$-dzin-av-s 'ele dorme' em que apenas o experienciador é codificado. Nesses casos, há de se perceber que uma marca de concordância no verbo (usualmente $-s$ ) está sempre presente independentemente de haver referência a um segundo argumento ou não. Segundo Tuite (1998), em línguas com mais de um conjunto de marcas de concordância, como é o caso do georgiano, é normalmente o caso que uma das marcas de um dos conjuntos deva sempre aparecer em verbos finitos. No georgiano, essa marca corresponde normalmente ao conjunto de afixos $A$, como é o caso da marca -s observada em verbos indiretos com um argumento apenas como s-dzin-av-s. É interessante, no entanto, notar certa semelhança em relação a construções impessoais em outras línguas, como no russo "menja (gen.) tošnit (sentir-se doente.3SG)"
} 


\subsection{Vogais pré-radicais}

Como o próprio nome já indica, as vogais pré-radicais - quando presentes -, ocupam, invariavelmente, o slot que imediatamente precede a raiz verbal, não sendo possível aparecerem duas vogais pré-radicais concomitantemente.

As vogais pré-radicais são conhecidas na literatura linguística georgiana como responsáveis por uma variedade de funções que só podem ser identificadas dentro do contexto morfossintático em que se encontram (cf. GUREVICH, 2006), pois interagem diretamente com propriedades distintas, como voz, estrutura argumental dos verbos, tempo/modo/aspecto, concordância verbal etc.

Essas diferentes funções pelas quais a vogal pré-radical é responsável nem sempre têm uma relação entre si, seja sincrônica ou diacrônica, que possa ser claramente estabelecida ou definida, sendo ainda motivo de discussão (cf. GUREVICH, 2006; TUITE, 2007). Ainda assim, dentro da literatura, algumas relações são comumente traçadas entre suas diferentes funções e propriedades, o que nos sugere que em algum ponto de sua história houve o que se poderia chamar de uma extensão de alguns dos seus usos mais 'primitivos' a outros.

Uma das funções centrais que é atribuída às vogais pré-radicais é a de versão verbal, à qual tentaremos nos ater no momento, passando depois às suas demais funções.

A versão verbal é conhecida em georgiano por incorporar à estrutura do verbo propriedades argumentais e semânticas, e segundo Gurevich (2006, p. 8), passa a indicar que aquele constituinte adicionado é afetado pela ação do verbo, atribuindo-lhe certo grau de saliência. Dessa forma, as versões verbais diferem entre si na medida em que marcam diferentes propriedades relacionadas ao verbo, e estas são:

'eu me sinto doente/nauseado', em que o verbo está flexionado na terceira pessoa do singular, mas não referencia nenhum nominal na sentença. O que acaba por diferenciar os verbos indiretos no georgiano de verbos impessoais, por ser uma língua que apresenta concordância no verbo com dois e, às vezes, até três argumentos na sentença, é que o nominal dativo também vai apresentar concordância no verbo através do conjunto de afixos $B$, inclusive, levando a preferência em alguns casos, como veremos à frente. 
- Versão objetiva - marcada pela vogal pré-radical - $i$ - quando o objeto indireto beneficiário da ação está na primeira ou segunda pessoa, e pela vogal pré-radical $-u$ quando o objeto estiver na terceira pessoa. Observe:
a. meri-m da-m-i-xat'-a
me
surat-i
Meri.ERG PV-1BDAT-VPR-pintar-3ANOM.SG.AOR 1SG.DAT quadro-NOM Meri pintou um quadro para mim. (GUREVICH, 2006)
b. meri-m da-u-xat'-a p'avle-s surat-i
Meri.ERG PV-VPR-pintar-3ANOM.SG.AOR Pavle-DAT quadro-NOM Meri pintou um quadro para Pavle. (GUREVICH, 2006)

- Versão subjetiva - marcada pela vogal pré-radical - $i$ - quando o sujeito for o participante afetado ou o beneficiário da ação exercida pelo verbo.
a. me saxl-s v-i-shen-eb
1SG casa-DAT 1ANOM-VPR-construir-ST
Eu construí uma casa para mim. (GUREVICH, 2006)

- Versão locativa - marcada pela vogal pré-radical - $a$ - quando houver um objeto indireto locativo, indicando, por exemplo, alguma relação espacial em relação à ação do verbo.

$$
\begin{aligned}
& \text { a. me v-a-t'ex-av jox-s tav-s } \\
& \text { 1SG 1ANOM-VPR-quebrar-ST bastão-DAT cabeça-DAT } \\
& \text { Eu quebrei um bastão em cima de sua cabeça. (GUREVICH, 2006) }
\end{aligned}
$$

- Versão neutra (ou zero) - marcada pela vogal pré-radical - $a$ - quando não houver nenhuma propriedade argumental ou semântica adicional ligada ao verbo. A versão neutra é encontrada em verbos transitivos como, por exemplo, a-mzad-eb 'preparar', 
sendo que a maior parte dos verbos com sufixo temático - eb- ocorre em conjunto com a versão neutra.

As funções descritas acima das versões verbais são encontradas em verbos de Classe I e verbos de Classe III. É importante notar que em relação à maior parte dos usos descritos acima, uma forma alternativa pode ser usada em vez da versão verbal que é o uso de um sintagma nominal posposicionado, isto é, há a possibilidade de usarmos uma posposição junto ao nome para expressar as relações semânticas associadas ao uso das versões. No entanto, a diferença sintática fundamental entre as duas possibilidades é que a versão verbal adiciona propriedades argumentais ao verbo, gerando concordância, enquanto que um sintagma posposicional não faz parte da estrutura argumental do verbo, não havendo concordância (HARRIS, 1981, p. 88).

Verbos de Classe II e IV por possuírem uma morfologia distinta, utilizam-se das vogias pré-radicais de forma um tanto peculiar, porém, relacionada.

Em verbos de Classe IV e em verbos nas Séries III que apresentam inversão, as vogais pré-radicais são usadas obrigatoriamente para indicar o sujeito 'lógico' no dativo: $-i$ - para primeira ou segunda pessoa e $-u$ - para terceira pessoa. No tempo maisque-perfeito, a vogal pré-radical - $e$ - é usada para todas as pessoas (HEWITT, 1995).

Embora, provavelmente, esse uso das vogais pré-radicais esteja relacionado historicamente ao uso da versão objetiva em verbos transitivos de Classe I e verbos de Classe II, sincronicamente, acaba por tomar diferentes funções, pois seu uso é obrigatório por razões diretamente ligadas à morfologia e sintaxe de verbos de Classe IV juntamente com morfologia de tempo/modo/aspecto em outras classes.

Assim, é igualmente requerida para marcar as Séries III tanto em verbos de Classe I quanto em verbos de Classe III que sofrem inversão, como pode ser observado na sentença com um verbo de Classe I no perfeito evidencial das Séries III 'mas saxli a$\boldsymbol{u}$-shen-eb-ia' - 'Ele (aparentemente) construiu a casa' -, em que a vogal pré-radical - $u$ concorda com o nominal no dativo de terceira pessoa mas 'ele', sendo obrigatória.

Em verbos intransitivos e passivos de Classe II, formados pela vogal pré-radical - $i$ - mais o sufixo temático $-e b$-, a alternância para a vogal pré-radical $-e$ - marca a presença de um argumento extra ou participante afetado, podendo indicar quaisquer propriedades semânticas listadas acima pelo uso das outras vogais pré-radicais (HEWITT, 1995, p. 204). Dessa forma, a vogal pré-radical - $e$ - marca o que seria um objeto indireto no dativo em verbos intransitivos (cf. HARRIS, 1981; HEWITT, 1995). 
Em adição a esses usos das vogais pré-radicais como versão verbal, as vogais pré-radicais - $i$ - e -e-são também responsáveis pela marcação de tempo/modo/aspecto de verbos de Classe III e verbos de Classe IV. Possuem, nesse caso, uma função particularmente 'gramatical', já que servem para formar o futuro e outros tempos verbais juntamente com o sufixo - eb- - compare o verbo de Classe III no presente das Séries I v-tamash-ob 'eu jogo', com o mesmo verbo no futuro v-i-tamash-eb, 'eu jogarei'.

Na literatura, sugere-se a hipótese de que, por verbos de Classe III (denotam uma atividade) e verbos de Classe IV (verbos psíquicos) serem considerados como atélicos, seria provável que houvesse uma restrição nesses verbos quanto ao uso dos preverbos, que denotam aspecto perfectivo e são usados na formação do futuro e outros tempos verbais em verbos télicos de Classe I e de Classe II. Dessa forma, talvez por extensão, os verbos de Classe III e IV tenham passado a formar o futuro com uma estrutura emprestada, i.e., com a vogal pré-radical mais o sufixo temático -eb-, forma esta idêntica à formação de verbos de Classe II (GUREVICH, 2006; TUITE, 2007, p. $10)$.

O que é interessante notar é que os verbos de Classe IV formam o futuro e outros tempos com a vogal pré-radical -e- juntamente com o sufixo temático - eb-, enquanto os verbos de Classe III usam a vogal pré-radical - $i$-. Assim, com a presença do sujeito 'lógico' no dativo em verbos psicológicos, a vogal pré-radical - $e$ - seria empregada em vez da vogal pré-radical $-i-$, lembrando de seu uso similar ao emprego da vogal pré-radical - $e$ - nos verbos de Classe II.

Outra função atribuída à vogal pré-radical - $i$ - é de passividade, sendo responsável pela formação de verbos passivos prefixais de Classe II, a passiva sintética como chamada por Harris (1981). Dessa forma, a vogal pré-radical - $i$ - derivaria tanto verbos passivos de Classe II quanto verbos inativos de Classe II.

Por fim, a vogal pré-radical - $i$ - também é usada em algumas formações reflexivas (cf. AMIRIDZE, 2006), função associada à versão subjetiva e à passividade em georgiano (cf. CYRINO, 2011; TUITE, 2007). 


\section{VERBOS COM MARCAÇÃO NÃO CANÔNICA EM GEORGIANO}

\subsection{Introdução}

Neste capítulo, discutiremos os verbos com marcação não canônica (dativa) em georgiano, sempre, no entanto, fazendo o esforço de trazer dados de outras línguas para a discussão, procedimento que, sem dúvida, enriqueceu e aprofundou nosso entendimento sobre o fenômeno estudado, i.e., as construções dativas com verbos experienciais.

Inicialmente, separamos na primeira seção os verbos experienciais (ou com sentido experiencial) com experienciadores no dativo por grupos semânticos para facilitar sua descrição. A listagem por grupos semânticos não pretende ser exaustiva, e sim representativa.

Em seguida, discutiremos cada grupo de verbos em georgiano e em outras línguas, apontando diferenças e semelhanças conceituais e estruturais importantes. Essa primeira discussão servirá de base para a caracterização conceitual no capítulo 7 que levará em conta os dados e conclusões tiradas na discussão dos grupos verbais.

Dessa forma, conclusões importantes serão já delineadas neste capítulo tanto quanto à caracterização conceitual desses verbos, quanto em relação à conexão conceitual entre diferentes grupos semânticos, como emocionais, físicos, de posse, modais e grupos menores.

Dessa forma, em cada seção, foram discutidos aspectos que nos chamaram a atenção no decorrer da pesquisa e por meio dos dados coletados, aspectos esses que serão importantes para o entendimento do domínio experiencial e para a caracterização conceitual de eventos experienciais.

$\mathrm{Na}$ seção sobre verbos emocionais e físicos, discutimos particularmente, pensando na marcação diferencial comum, ou não, entre esses dois tipos de eventos nas línguas, possíveis similaridades e diferenças conceituais, concluindo que as semelhanças conceituais parecem ser mais salientemente evocadas nas línguas do que as diferenças, indicando possivelmente que há uma conceitualização experiencial mais abstrata comum aos dois.

$\mathrm{Na}$ seção sobre eventos de percepção e cognição, discutimos frequentes extensões que ocorrem com verbos de percepção e cognição e também, em relação aos 
primeiros, o frequente contraste entre verbos perceptuais ativos e inativos, gerando marcações diferenciadas e que se afastam de diferentes formas de eventos mais canônicos e mais transitivos.

$\mathrm{Na}$ seção sobre verbos modais, apontamos a relação entre modais e nuances experienciais, sendo algumas extensões frequentemente encontradas, além de apontarmos para a importância da não volicionalidade na caracterização desses eventos.

$\mathrm{Na}$ seção sobre posse, discutimos a conexão nas línguas entre construções dativas de posse e experiencial, sendo que em eventos de posse há frequentemente o desenvolvimento de uma maior afetação por parte do possuidor, à semelhança de eventos experienciais emotivos e físicos. Essa relação próxima entre posse e eventos experienciais nos fez trazer a discussão de Langacker na GC sobre pontos de referência e a relação entre posse e construções locativas. Sua análise é importante, pois traz alguns indícios da relação conceitual entre construções de posse, experienciais e locativas, relação essa que será explorada também nos capítulos 6 e 7 .

$\mathrm{Na}$ seção sobre verbos ontológicos, veremos que o fato de eventos de similaridade e dissimilaridade serem eventos simétricos, em contraste com eventos assimétricos, é um fator importante na marcação diferenciada desses tipos de eventos nas línguas.

Na seção sobre verbos atitudinais, será visto que esses eventos se aproximam de eventos experienciais por indicarem uma disposição, um estado mental, em relação a alguma atividade, atitude ou propriedade do experienciador.

Na seção sobre verbos desiderativos e de julgamento, perceberemos que o fator da não volicionalidade é crucial, adicionando uma nuance experiencial a eventos que, do contrário, seriam eventos não experienciais e usualmente mais volitivos.

Nas seções seguintes, faremos discussões importantes sobre dados do georgiano (e outras línguas), tais como a marcação diferencial de objeto (DOM), em que veremos aspectos importantes da marcação diferencial do estímulo que servem de indício para a caracterização conceitual proposta no capítulo 7; a importância da volição em construções dativas, salientando mais uma vez a pervasividade do construal nas línguas, pois mesmo eventos considerados como prototipicamente menos volitivos ou mais volitivos podem ser construídos diferencialmente, sendo mais um ponto a favor da discussão do capítulo 3, em que foi argumentado, trazendo a análise de Grafmiller (2013), que efeitos de prototipicidade e o papel do construal são preferíveis a análises de classes com limites precisos a partir de noções necessárias ou dicotômicas. 
Também veremos a mudança sintática ocorrida em construções dativas do georgiano antigo ao moderno, apontando para a maior proeminência conceitual adquirida pelo participante dativo, dado que contribuirá para a caracterização conceitual dessas construções no capítulo 7.

$\mathrm{Na}$ seção sobre evidencialidade, discutiremos seus significados no georgiano e potenciais razões para sua marcação diferencial e sua relação com não volicionalidade e sentidos experienciais.

$\mathrm{Na}$ última seção sobre verbos causais indiretos no georgiano, mostraremos a variação encontrada nesses verbos tanto em relação a contrastes de volição, quanto em relação à proeminência dada à causa ou ao experienciador dativo

\subsection{Descrição dos grupos semânticos}

A designação 'construções indiretas' ou 'verbos indiretos' que se encontra, frequentemente, na literatura linguística do georgiano é entendida, do ponto de vista gramatical, como a inversão de certas propriedades atribuídas às construções diretas: o argumento que é geralmente identificado como sujeito de uma construção direta, por exemplo, o agente de uma sentença transitiva de Classe I - marcado nas Séries I com o caso nominativo e nas Séries II com o caso ergativo e referenciado pelo conjunto de afixos $\mathrm{A}$ - é, em uma construção indireta, marcado pelo caso dativo e referenciado pelo conjunto de afixos B (TUITE, 1998).

Esse entendimento de marcação diferenciada ou inversão da marcação mais 'padrão', no que diz respeito a relações gramaticais centrais como sujeito e objeto, se traduz na literatura linguística, no geral, através do rótulo de marcação não canônica de argumentos.

Segundo Onishi (2001), os tipos de verbos tipicamente envolvidos em marcações não canônicas são aqueles que se referem a eventos psicológicos, fisiológicos, de cognição, percepção; verbos modais de desejo, obrigação; verbos de acontecimentos, de posse, existência e falta.

No georgiano, a maior parte dos predicados verbais psicológicos que ocorrem em construções com o experienciador no dativo (DatExp) pertencem morfologicamente à Classe IV, o que significa dizer que esses verbos possuem uma marcação (tanto em 
relação às marcas de concordância no próprio verbo quanto em relação às marcas de caso nos nominais que o acompanham) que se mantém constante em todas as Séries. Esse fator em si é interessante do ponto de vista do sistema verbal do georgiano como um todo, pois como pôde ser observado através da descrição do sistema verbal do georgiano no capítulo anterior, a marcação de caso e a marcação de concordância no verbo não se apresentam de forma constante nas Séries, havendo variação em relação ao tipo de predicado e Série.

Dessa forma, verbos de Classe IV despontam com uma marcação bastante sólida dentro do sistema, evidenciando certa uniformidade em relação à presença do caso dativo e das marcas do conjunto de afixos B como marca de sujeito 'lógico' em todas as Séries. ${ }^{65}$

Separaremos, nesta seção, verbos experienciais (ou com sentido experiencial) com DatExp por grupos semânticos para facilitar sua descrição. A listagem por grupos semânticos não pretende ser exaustiva, e sim representativa. Os grupos semânticos foram adaptados de estudos como Barðdal (2004) e Barðdal et al (2012).

Os verbos listados a seguir foram retirados, além de fontes próprias, de gramáticas (HEWITT, 1998, CAMPBELL, s/d), dicionários (CAMPBELL, s/d(b); TSCHENKELI, 1974; RAYFIELD, 2006) e estudos como Harris (1981) e Cherchi (1997) que fez uma compreensiva descrição acerca, particularmente, da Classe IV.

\begin{tabular}{|l|l|}
\hline Verbos de emoção: & Exemplos: \\
\hline$u-q$ 'var-s 'amar' & $\begin{array}{l}\text { m-i-qvar-xar - 'Eu } \\
\text { u-quar-t }- \text { 'Eles/as o/a amam. } \\
\text { u-qvar-s - 'Ele/a o/a/ ama.' }\end{array}$ \\
\hline mo-s-c'on-s 'gostar' & $\begin{array}{l}\text { mo-m-c'on-xar - 'Eu } \\
\text { mo-s-c'on-t - 'Eles/as gostam dele/a.' } \\
\text { mo-s-c'on-s - 'Ele/a gosta dele/a.' }\end{array}$ \\
\hline
\end{tabular}

\footnotetext{
65 Nosso intuito, como já foi exposto anteriormente, não é provar a uniformidade, seja semântica ou estrutural, de uma classe, a Classe IV, mas sim estudar as construções dativas com verbos psicológicos. Assim sendo, o parâmetro para delimitar o objeto não é se tal verbo pertence ou não à determinada classe ou morfologia específica, mas sim se a construção como um todo se apresenta como tendo um participante marcado com o caso dativo e como predicado um verbo experiencial, ou que tenha ou adquira sentido mais 'experiencial' (caso de verbos desiderativos, por exemplo). Essa decisão inclui muitos verbos que do contrário ficariam de fora da análise se apenas verbos formalmente delimitados de Classe IV fossem considerados, como é o caso do trabalho de Cherchi (1997) que delimitou critérios morfossintáticos para o pertencimento de verbos na Classe IV e com base nisso fez sua análise.

${ }^{66}$ Observe que a vogal pré-radical - $u$ - é usada quando o nominal no dativo é de terceira pessoa, já a vogal pré-radical -i- quando o nominal no dativo é de primeira ou segunda pessoa.
} 


\begin{tabular}{|c|c|}
\hline$e$-shin-ia 'temer, ter medo' & $\begin{array}{l}\text { m-e-shin-ia - 'EudDAT tenho medo'. +GEN } \\
\text { e-shin-ia - 'Você tem medo.' }\end{array}$ \\
\hline$e$-nat'r-eb-a 'sentir falta' & $\begin{array}{l}\text { m-e-nat'r-eb-a - 'Eu } \text { DAT }_{\text {sinto falta dele/a }} \text { sOM' } \\
\text { e-nat'r-eb-a - 'Ele/a sente falta dele/a.' }\end{array}$ \\
\hline $\begin{array}{l}\text { u-xar-ia } \\
\text { feliz/satisfeito' }\end{array}$ & $\begin{array}{l}\text { m-i-xar-ia - 'Eu } \\
\text { u-xar-ia - 'Você está feliz/satisfeito.' }\end{array}$ \\
\hline$s-d z u l-s$ 'odiar' & $\begin{array}{l}\text { m-dzul-s - 'Eu } \\
\text { s-dzul-s - 'Ele/a odeio ele/a ele/a.' }\end{array}$ \\
\hline$u-k$ 'vir-s 'estar surpreso' & $\begin{array}{l}\text { m-i-k’vir-s - 'Eu } \\
\text { u-k'vir-s - 'Ele/a está surpreso.' }\end{array}$ \\
\hline $\begin{array}{l}\text { shur-s 'ter ciúmes, ter } \\
\text { inveja' }\end{array}$ & $\begin{array}{l}\text { m-shur-s - Eu } \\
\text { shur-s - 'Ele/a tem ciúmes.' }\end{array}$ \\
\hline $\begin{array}{l}e-z a r-e b-a \\
\text { desinteresse/estar apático, } \\
\text { preguiçoso' }\end{array}$ & $\begin{array}{l}\text { m-e-zar-eb-a - 'Eun } \\
\text { e-zar-eb-a - 'Ele/a tem desinteresse.' }\end{array}$ \\
\hline aint'eres-eb-s 'ter interesse' & $\begin{array}{l}\text { m-aint'eres-eb-s - 'Eu } \\
\text { aint'res-eb-s - 'Ele/a tem interesse.' }\end{array}$ \\
\hline $\begin{array}{l}u \text {-martl-eb-s 'sentir-se com } \\
\text { sorte/ ter sorte' }\end{array}$ & $\begin{array}{l}\text { m-i-martl-eb-s - 'Eu } u_{\text {DAT }} \text { me sinto com sorte.' } \\
\text { u-martl-eb-s - 'Ele/a se sente com sorte.' }\end{array}$ \\
\hline $\begin{array}{l}\text { s-cxven-ia 'envergonhar- } \\
\text { se/ter vergonha' }\end{array}$ & $\begin{array}{l}\text { m-cxven-ia - 'Eu } \\
\text { s-cxven-ia - 'Ele/a sente vergonha.' }\end{array}$ \\
\hline $\begin{array}{l}e \text {-rid-eb-a 'sentir-se tímido/ } \\
\text { embaraçado' }\end{array}$ & $\begin{array}{l}\text { m-e-rid-eb-a - 'Eu } \\
\text { e-rid-eb-a - 'Ele/a se sente tímido/a.' }\end{array}$ \\
\hline $\begin{array}{llr}\text { u-ch'ir-s } & \text { 'estar } & \text { em } \\
\text { dificuldade, } & & \text { sentir } \\
\text { dificuldade' } & & \\
& & \end{array}$ & $\begin{array}{l}\text { m-i-ch'ir-s - 'Eund estou em dificuldade.' } \\
\text { u-ch'ir-s - 'Ele/a está em dificuldade.' }\end{array}$ \\
\hline $\begin{array}{l}s \text {-ch'ir-s 'estar } \quad \text { em } \\
\text { necessidade, precisar' }\end{array}$ & $\begin{array}{l}\text { m-ch'ir-s - 'Eu } \\
\text { s-ch'ir-s - 'Ele/a está em necessidade.' }\end{array}$ \\
\hline$e$-am-eb-a 'sentir prazer' & $\begin{array}{l}\text { m-e-am-eb-a - 'Eu } u_{\text {DAT }} \text { sinto prazer.' } \\
\text { e-am-eb-a - 'Ele/a sente prazer.' }\end{array}$ \\
\hline $\begin{array}{l}e \text {-amaq-eb-a 'sentir-se } \\
\text { orgulhoso, orgulhar-se' }\end{array}$ & $\begin{array}{l}\text { m-e-amaq-eb-a - 'Eu } \text { DAT }_{\text {me sinto orgulhoso.' }} \\
\text { e-amaq-eb-a - 'Ele/a se sente orgulhoso.' }\end{array}$ \\
\hline$e$-nan-eb- $a$ 'arrepender-se' & $\begin{array}{l}\text { m-e-nan-eb-a - 'Eu } \text { DAT }_{\text {me arrependo.' }} \\
\text { e-nan-eb-a - 'Ele/a se arrepende.' }\end{array}$ \\
\hline $\begin{array}{l}\text { bezr-d-eb-a 'entediar-se, } \\
\text { estar entediado' }\end{array}$ & $\begin{array}{l}\text { m-bezr-d-eb-a - 'Eu EuAT estou entediado/a.' } \\
\text { e-bezr-eb-a - 'Ele/a está entediado/a.' }\end{array}$ \\
\hline
\end{tabular}




\begin{tabular}{|c|c|}
\hline $\begin{array}{l}e-z i z g h-e b-a \text { 'achar alguma } \\
\text { coisa odiosa' }\end{array}$ & $\begin{array}{l}\text { m-e-zizgh-eb-a - 'Eu } \\
\text { e-zizgh-eb-a - 'Ele/a acho odiososo.' }\end{array}$ \\
\hline$e$-sizmr-eb-a 'ver em sonho' & $\begin{array}{l}\text { m-e-sizmr-eb-a - 'Eu } u_{\text {DAT }} \text { vi em sonho.' } \\
\text { e-sizmr-eb-a - 'Ele/a vê em sonho.' }\end{array}$ \\
\hline $\begin{array}{l}e-c o d-e b-a \text { 'ter pena, sentir } \\
\text { pena' }\end{array}$ & $\begin{array}{l}\text { m-e-cod-eb-a - 'Eu } \\
\text { e-cod-eb-a - 'Ele/a tem peno pena.' }\end{array}$ \\
\hline $\begin{array}{l}s-c \text { 'qin-s } s \text { 'sentir-se } \\
\text { aborrecido, triste' }\end{array}$ & $\begin{array}{l}\text { m-c'qin-s - 'Eu } \\
\text { s-c'qin-s - 'Ele/a se sente aborrecido.' }\end{array}$ \\
\hline sur-s 'desejar' & $\begin{array}{l}\text { m-sur-s - 'Eu } \\
\text { sur-s - 'Ele/a deseja isso.' }\end{array}$ \\
\hline$s$-c'ad-ia 'ansiar' & $\begin{array}{l}\text { m-c'ad-ia - 'EudDAT anseio.' } \\
\text { s-c'ad-ia - 'Ele/a anseia.' }\end{array}$ \\
\hline$u-n d-a$ 'querer' & $\begin{array}{l}\text { m-ind-a - 'Eu } \\
\text { u-nd-a - 'Ele/a quer.' }\end{array}$ \\
\hline$h-n e b-a v-s$ 'querer' & $\begin{array}{l}\text { m-neb-av-s - 'Eu } \\
\text { h-neb-av-s - 'Ele/a quero.' }\end{array}$ \\
\hline $\begin{array}{l}e \text {-xalis-eb-a 'estar } \\
\text { entusiasmado' }\end{array}$ & $\begin{array}{l}\text { m-e-xalis-eb-a - 'Eu } u_{\text {DAT }} \text { estou entusiasmado/a.' } \\
\text { e-xalis-eb-a - 'Ele/a está entusiasmado/a.' }\end{array}$ \\
\hline dzag-s 'sentir nojo, ódio' & $\begin{array}{l}\text { m-dzag-s - 'Eu } \\
\text { dzag-s - 'Ele/a sente nojo.' }\end{array}$ \\
\hline
\end{tabular}

Tabela 7: Verbos de emoção em georgiano

O verbo eshinia, assim como os verbos scxvenia 'ter vergonha', erideba 'sentirse tímido/embaraçado', jers/sc'ams 'acreditar/confiar', tem uma marcação de caso peculiar: o estímulo é marcado com o caso genitivo (cf. CHIKOIDZE, 2007; HEWITT, 1998). Observe o exemplo abaixo:

$$
\begin{aligned}
& \text { me m-e-shin-i-a } \\
& \text { 1SG.DAT 1BDAT-VPR-temer- ST-3ANOM } \\
& \text { Eu tenho medo de cachorros. }
\end{aligned}
$$

dzaghl-eb-is

$$
\text { cachorro-PL-GEN }
$$

Outro verbo encontrado com o mesmo padrão de marcação dos verbos citados acima é o verbo shur-s 'ter inveja', observe: 
a. zogjer m-shur-s im bich'-eb-is,

às vezes 1BDAT-invejar-3ANOM aquele garoto-PL-GEN

visac mama gverd-shi u-dgas

que pai.NOM lado-em VPR-crescer

Às vezes eu tenho inveja daqueles garotos que cresceram com o pai ao seu lado. ${ }^{67}$

Um detalhe interessante a respeito da marcação de caso do estímulo desses verbos indiretos, é que nos casos em que o nominal fizer referência a um pronome pessoal, deverá ser usado no lugar um adjetivo possessivo no caso nominativo (ou nominativo do genitivo como descreve Cherchi (1997)). Assim, frases como: "você tem medo de mim' e 'ele tem medo de você' ficariam, respectivamente, "shen (dat.) chemi (nom.) g-shin-ia" e “mas (dat.) sheni (nom.) e-shin-ia" (ARONSON, 1990; HEWITT, 1998). ${ }^{68}$

A marcação não-canônica do estímulo, apresentada por esses verbos, será discutida em particular na seção 5.4.

O próximo grupo de verbos é o de estados físicos ou corporais. Observe o exemplo abaixo:

a. giorgis tav-i s-t'k'i-od-a

George.DAT cabeça-NOM 3BDAT-ter.dor-IMPF-3ANOM

George sentia dor de cabeça. (CAMPBELL, s/d)

\begin{tabular}{|l|l|}
\hline Verbos de estado físico: & Exemplos: \\
\hline$s-t$ ' $k$ ' $i v-a$ 'ter dor/ sentir dor' & m-t'k'iv-a - 'Eu ${ }^{\text {DAT }}$ sinto dor.' \\
& s-t'k'iv-a - 'Ele/a sente dor.' \\
& s-t'k'iv-a-t - 'Eles sentem dor.' \\
\hline
\end{tabular}

${ }^{67}$ Exemplo retirado de: https://www.jw.org/ka

${ }^{68}$ Segundo Harris (1981) e Cherchi (1997), o verbo esmis 'ouvir, entender', às vezes, pode aparecer com o estímulo no caso genitivo, como na frase 'eu entendo/ouço você' me (dat.) sheni (nom.) $m$-e-sm-is. 


\begin{tabular}{|c|c|}
\hline$s-c i v-a$ 'sentir frio' & $\begin{array}{l}\text { m-civa - 'Eu } \\
\text { s-civa - 'Ele/a sente frio.' } \\
\text { s-civa-t - 'Eles/as sentem frio.' }\end{array}$ \\
\hline shia 'sentir fome' & $\begin{array}{l}\text { m-shia - 'Eu }{ }_{\mathrm{DAT}} \text { sinto fome.' } \\
\text { shia - 'Ele/a sente fome.' } \\
\text { shia-t - 'Eles/as sentem fome.' }\end{array}$ \\
\hline$s-c$ 'qur-ia 'sentir sede' & $\begin{array}{l}\text { m-c'qur-ia - 'Eu } \\
\text { s-c'qur-ia - 'Ele/a sente sede.' } \\
\text { s-c'qur-ia-t - 'Eles/as sentem sede.' }\end{array}$ \\
\hline$a-x v e l-e b-s$ 'ter tosse, tossir' & $\begin{array}{l}\text { m-a-xvel-eb-s - 'Eu } \\
\text { a-xvel-eb-s - 'Ele/a tosse.' }\end{array}$ \\
\hline$s$-cxel-a 'estar com calor' & $\begin{array}{l}\text { m-cxela - Eu } \\
\text { s-cxela - 'Ele/a estou com calor.' } \\
\text { s-m calor.' }\end{array}$ \\
\hline$d z i n-a v-s$ 'dormir' & $\begin{array}{l}\text { m-dzin-av-s - 'Eu } \\
\text { dzin-av-s - 'Ele/a dorme.' }\end{array}$ \\
\hline h-ghvidz-av-s 'estar acordado' & h-ghvidz-av-s - 'Ele/a ${ }_{D A T}$ está acordado/a.' \\
\hline tbil- $a$ 'estar quente' & $\begin{array}{l}\text { m-tbil-a - 'Eu }{ }_{\text {DAT }} \text { estou quente.' } \\
\text { tbil-a - '(Ele/a) está quente.' }\end{array}$ \\
\hline
\end{tabular}

Tabela 8: Verbos de sensação física em georgiano

O próximo grupo semântico é dos verbos de cognição. Observe o exemplo a seguir com o verbo hgonia 'pensar, parecer':
a. me
m-gon-i-a,
rom shen gajavrebuli xar
1SG.DAT 1BDAT-achar-ST-3ANOM que você nervoso COP.2SG
Acho que você está nervoso. (CAMPBELL, s/d)

\begin{tabular}{|l|l|}
\hline Verbos de cognição: & Exemplos: \\
\hline $\begin{array}{l}\text { h-gon-ia 'pensar, achar, ter a } \\
\text { impressão, parecer que' }\end{array}$ & $\begin{array}{l}\text { m-gon-ia - 'Eu } \\
\text { h-gon-ia - 'Ele/a pensa/acha.' }\end{array}$ \\
\hline $\begin{array}{l}\text { achn-ia 'considerar, supor' } \\
\text { e-ech'v-eb-a 'duvidar/ver comn-ia - Eund considero.' } \\
\text { achn-ia - 'Ele/a considera.' }\end{array}$ & $\begin{array}{l}\text { m-e-ech'v-eb-a - 'Eund duvido.' } \\
\text { e-ech'v-eb-a - 'Ele/a duvida.' }\end{array}$ \\
\hline
\end{tabular}




\begin{tabular}{|c|c|}
\hline desconfiança' & \\
\hline$e$-smi-s 'entender/ouvir' & $\begin{array}{l}\text { m-esmi-s- 'Eu } \\
\text { e-smi-s - 'Ele/a entende.' }\end{array}$ \\
\hline $\begin{array}{l}s-c \text { 'am-s 'acreditar/confiar' } \\
\text { jer-s 'acreditar/confiar' }\end{array}$ & $\begin{array}{l}\text { m-c'am-s - Eu } \\
\text { m-jer-s - 'EuT acredito.' +GEN } \\
\text { DuT acredito.' }\end{array}$ \\
\hline u-rchevn-ia 'preferir' & $\begin{array}{l}\text { m-i-rchevn-ia - Eu } \text { DAT }_{\text {prefiro }}\left(\mathrm{ele} / \mathrm{a}_{\mathrm{NOM}}\right)^{\prime} \\
\text { u-rchevn-ia - 'Ele/a prefere (ele/a) }\end{array}$ \\
\hline$a-x s-o v-s$ 'lembrar' & $\begin{array}{l}\text { m-a-Xs-ov-s - Eu } \\
\text { a-Xs-ov-s - 'Ele/a lembra.' }\end{array}$ \\
\hline$a$-vic'q-d-eb-a 'esquecer' & $\begin{array}{l}\text { m-a-vic'q-d-eb-a - 'Eu }{ }_{\text {DAT }} \text { esqueço.' } \\
\text { a-vic'q-d-eb-a - 'Ele/a esquece.' }\end{array}$ \\
\hline
\end{tabular}

Tabela 9: Verbos de cognição em georgiano

O próximo é o grupo de verbos de percepção:

(50)
a. me
m-a-xs-ov-s
sheni
xma
1SG.DAT 1BDAT-VPR-lembrar-ST-3ANOM.SG sua.NOM voz-NOM

Eu me lembro da sua voz.

\begin{tabular}{|c|c|}
\hline Verbos de percepção: & Exemplos: \\
\hline esmi-s 'ouvir/entender' & $\begin{array}{l}\text { m-esmi-s- 'Eu } \\
\text { esmi-s - 'Ele/a ouve.' }\end{array}$ \\
\hline $\begin{array}{l}\text { e-gem-eb-a 'sentir o gosto, } \\
\text { experimentar' } \\
\text { (cf. no inglês: it tastes to him; he } \\
\text { tastes it) }\end{array}$ & $\begin{array}{l}\text { m-e-gem-eb-a - 'Eu } \\
\text { e-gem-eb-a - '(Ele/a) sentir o gosto.' }\end{array}$ \\
\hline $\begin{array}{l}\text { e-qnos-eb-a 'sentir o cheiro, } \\
\text { cheirar' } \\
\text { (cf. no inglês: it smells to him; he } \\
\text { smells it) }\end{array}$ & $\begin{array}{l}\text { m-e-nos-eb-a - 'Eu } \\
\text { e-gem-eb-a - '(Ele/a) sinto o cheiro.' }\end{array}$ \\
\hline
\end{tabular}

Tabela 10: Verbos de percepção em georgiano 
O próximo grupo é o de verbos de modalidade que inclui verbos de obrigação, dever e falta:

a. ra m-a-k'l-i-a?

o que 1BDAT-VPR-falta- ST-3ANOM

O que falta em mim?

\begin{tabular}{|c|c|}
\hline Verbos de modalidade: & Exemplos: \\
\hline $\begin{array}{l}a-k \text { 'l-ia 'faltar' } \\
\text { Inceptivo indireto: } a-k \text { 'l-d-eb-a} \\
\text { 'faltar, sofrer privação/redução de } \\
\text { alguma coisa'. }\end{array}$ & $\begin{array}{l}\text { m-a-k'l-ia - 'Me } \mathrm{e}_{\mathrm{DAT}} \text { falta alguma coisa }{ }_{\mathrm{NOM}} \text { ' } \\
\text { (cf. no inglês I lack something) }\end{array}$ \\
\hline $\begin{array}{l}\text { h-mart-eb-s 'ter um dever, dever } \\
\text { (alguma coisa a alguém)' }\end{array}$ & $\begin{array}{l}\text { m-mart-eb-s - Eu } \\
\text { h-mart-eb-s - 'Ele/a tem o o dever.' }\end{array}$ \\
\hline she-u-dzl-ia' 'poder, ser capaz de' & $\begin{array}{l}\text { she-m-i-dzl-ia- 'Eu }{ }_{\text {DAT }} \text { posso, sou capaz de.' } \\
\text { she-u-dzl-ia - 'Ele/a pode, é capaz de.' }\end{array}$ \\
\hline
\end{tabular}

Tabela 11: Verbos de modalidade em georgiano

O próximo grupo é o de verbos de posse. Observe que a escolha entre os verbos $a-k v-s$ e $h-q a v-s$ depende da animacidade do objeto, o primeiro é usado com objetos inanimados (em 51a), e o segundo, com objetos animados (em 51b):

a. me

m-a-kv-s

c'ign-i

1SG.DAT

1BDAT-VPR-ter-3ANOM.SG

livro-NOM

Eu tenho um livro.

b. me

m-qav-s

da

1SG.DAT

1BDAT-ter-3ANOM.SG

irmã.NOM

Eu tenho uma irmã.

Já o exemplo abaixo é do verbo $h$-kvia 'ser chamado': 


$\begin{array}{llll}\text { chem-s } & \text { k'at'a-s } & \text { t'omi } & \text { kv-i-a } \\ \text { meu-DAT } & \text { gato-DAT } & \text { tomi.NOM } & \text { chamar-ST-3ANOM } \\ \text { Meu gato se chama Tomi. } & \text { (CAMPBELL, s/d) }\end{array}$

\begin{tabular}{|c|c|}
\hline Verbos de posse: & Exemplos: \\
\hline $\begin{array}{l}a k v-s \text { 'ter (objetos inanimados)' } \\
h-q a v-s \text { 'ter (objetos animados)' }\end{array}$ & 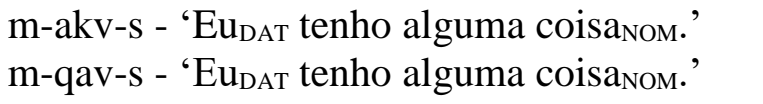 \\
\hline $\begin{array}{l}h-k v \text {-ia 'ser chamado, ser } \\
\text { nomeado' }\end{array}$ & $\begin{array}{l}\text { m-kv-ia - 'Eu } \\
\text { h-kv-ia - 'Ele/a é chamado, nomeado.' }\end{array}$ \\
\hline $\begin{array}{l}\text { u-p'qr-ia 'estar segurando, } \\
\text { segurar' }\end{array}$ & $\begin{array}{l}\text { m-i-p'qr-ia - 'Eu } \text { DAT }_{\text {sT }} \text { seguro alguma coisa } \\
\text { u-p'qr-ia - 'Ele/a está segurando alguma coisa.' }\end{array}$ \\
\hline
\end{tabular}

Tabela 12: Verbos de posse em georgiano

O próximo grupo é o de verbos de estados ontológicos que inclui verbos de similaridade, dissimilaridade, propriedades e habilidades. Observe o exemplo a seguir:
chven-i sxeul-i bevri ramit
h-gav-s
nosso-NOM corpo-NOM muito alguma.coisa 3BDAT-ser.similar-3ANOM.SG
cxovel-is
sxeul-s
animal-GEN
corpo-DAT

Em muitos aspectos, nosso corpo se assemelha ao corpo do animal. ${ }^{69}$

\begin{tabular}{|c|c|}
\hline Verbos de estados ontológicos: & Exemplos: \\
\hline $\begin{array}{l}h \text {-gav-s 'parecer, ser similar, } \\
\text { assemelhar-se' }\end{array}$ & $\begin{array}{l}\text { m-gav-s - 'Eu } \\
\text { coisa/alguém me pareço com alguma }\end{array}$ \\
\hline
\end{tabular}

Tabela 13: Verbos de estados ontológicos em georgiano

O próximo é o grupo de verbos que denota estados atitudinais ou disposições:

${ }^{69}$ Exemplo retirado de: https://wol.jw.org/ka/wol/d/r20/lp-ge/2015008 

a. $\quad$ ara
m-cal-i-a
1BDAT-ter.tempo.livre-ST-3ANOM

Eu não tenho tempo livre.

\begin{tabular}{|c|c|}
\hline $\begin{array}{l}\text { Verbos que denotam estados } \\
\text { atitudinais: }\end{array}$ & Exemplos: \\
\hline$e-m e t$ '-eb-a 'ser generoso' & $\begin{array}{l}\text { m-e-met'-eb-a - 'Eu } E u_{\text {DAT }} \text { sou generoso/a.' } \\
\text { e-met'-eb-a - 'Ele/a é generoso/a.' }\end{array}$ \\
\hline $\begin{array}{l}\text { e-chkar-eb-a 'estar com pressa, } \\
\text { estar apressado' }\end{array}$ & $\begin{array}{l}\text { m-e-chkar-eb-a - 'Eu } u_{\text {DAT }} \text { estou com pressa.' } \\
\text { e-chkar-eb-a - 'Ele/a está com pressa.' }\end{array}$ \\
\hline cal-ia 'ter tempo livre' & $\begin{array}{l}\text { m-cal-ia - 'Eu } u_{D A T} \text { tenho tempo livre.' } \\
\text { cal-ia - 'Ele/a tem tempo livre.' }\end{array}$ \\
\hline
\end{tabular}

Tabela 14: Verbos de estados atitudinais em georgiano

Um grupo de verbos indiretos particularmente produtivo (no sentido de atrair novos lexemas verbais) é o de verbos comumente chamados de desiderativos. O experienciador desses verbos é marcado com o caso dativo e experiencia o evento denotado pela raiz do verbo de forma não volitiva, não tendo controle sobre a ação. Assim, esses verbos desiderativos, derivados muitas vezes de outras Classes de verbos diretos, passam a exprimir vontade ou desejo de fazer aquela ação, observe:

(55) Verbos desiderativos

a. m-e-mgher-eb-a

1BDAT-VPR-cantar-ST-3ANOM

Eu sinto desejo de cantar, estou no humor de cantar.

b. m-e-cek'v-eb-a

1BDAT-VPR-dançar-ST-3ANOM

Eu sinto desejo de dançar.

c. m-e-cin-eb-a

1BDAT-VPR-rir-ST-3ANOM

Eu sinto desejo de rir.

[Adaptados de Asatiani (1998)] 


\begin{tabular}{|c|c|}
\hline Verbos desiderativos: & Exemplos: \\
\hline $\begin{array}{l}\text { e-mgher-eb-a 'sentir desejo de } \\
\text { cantar' } \\
\text { Correspondente agentivo de } \\
\text { morfologia de Classe III: } v \text { - } \\
m g h e r-i \text { 'eu canto' }\end{array}$ & $\begin{array}{l}\text { m-e-mgher-eb-a - 'Eu } u_{\text {DAT }} \text { sinto desejo de cantar.' } \\
\text { e-mgher-eb-a - 'Ele/a sente desejo de cantar.' }\end{array}$ \\
\hline $\begin{array}{l}\text { e-cek'v-eb-a 'sentir desejo de } \\
\text { dançar' } \\
\text { Correspondente agentivo de } \\
\text { morfologia de Classe III: } v \text {-cek'v- } \\
a v \text { 'eu danço' }\end{array}$ & $\begin{array}{l}\text { m-e-cek'v-eb-a - Eu } u_{\text {DAT }} \text { sinto desejo de dançar.' } \\
\text { e-cek’v-eb-a - 'Ele/a sente desejo de dançar.' }\end{array}$ \\
\hline $\begin{array}{l}e \text {-cin-eb-a 'sentir desejo de rir' } \\
\text { Correspondente agentivo de } \\
\text { morfologia de Classe III: } v-i-\operatorname{cin}-i \\
\text { 'eu rio' }\end{array}$ & $\begin{array}{l}\text { m-e-cin-eb-a - 'Eu } \\
\text { e-cin-eb-a - 'Ele/a sente desejo de rir.' }\end{array}$ \\
\hline $\begin{array}{l}\text { e-tamash-eb-a 'sentir desejo de } \\
\text { jogar' } \\
\text { Correspondente agentivo de } \\
\text { morfologia de Classe III: v- } \\
\text { tamash-ob-s 'eu jogo' }\end{array}$ & $\begin{array}{l}\text { m-e-tamash-eb-a - 'Eu } \text { DAT }_{\text {sinto desejo de jogar' }} \\
\text { e-tamash-eb-a - 'Ele/a sente desejo de jogar.' }\end{array}$ \\
\hline $\begin{array}{l}\text { e-dzin-eb-a 'sentir desejo de } \\
\text { dormir, sentir-se sonolento' } \\
\text { Correspondente de morfologia de } \\
\text { Classe IV: m-dzin-av-s 'eu } \\
\text { durmo' }\end{array}$ & $\begin{array}{l}\text { m-e-dzin-eb-a - 'Eu } \\
\text { e-dzin-eb-a - 'Ele/a sente desejo de dormir.' }\end{array}$ \\
\hline $\begin{array}{l}e-g h v i n-e b-a \text { 'sentir desejo de } \\
\text { tomar vinho' }\end{array}$ & $\begin{array}{l}\text { m-e-ghvin-eb-a - 'Eu } \\
\text { vinho' } \\
\text { e-ghvin-eb-a - 'Ele/a sente desejo de tomar } \\
\text { vinho.' }\end{array}$ \\
\hline $\begin{array}{l}\text { e-t'ir-eb-a 'sentir desejo de } \\
\text { chorar' } \\
\text { Correspondente de morfologia de } \\
\text { Classe III: } v-t \text { 'ir- } i-s \text { 'eu choro' }\end{array}$ & $\begin{array}{l}\text { m-e-t'ir-eb-a - 'Eu } \\
\text { e-t'ir-eb-a - 'Ele/a sente desejo de chorar.' }\end{array}$ \\
\hline $\begin{array}{l}e-m t k n a r-e b-a \text { 'sentir desejo de } \\
\text { bocejar' }\end{array}$ & $\begin{array}{l}\text { m-e-mtknar-eb-a - 'Eu } \\
\text { bocejar' } \\
\text { e-mtknar-a - 'Ele/a sente desejo de bocejar.' }\end{array}$ \\
\hline
\end{tabular}

Tabela 15: Verbos desiderativos em georgiano

Esses verbos modais são um caso interessante, pois, em sua maior parte, tornam em eventos não agentivos e não volitivos ações que, do contrário, seriam caracterizadas como agentivas e não psicológicas, ocasionando, na derivação, o envolvimento de um experienciador no dativo. 
Verbos como e-cin-eb-a, citado acima, e outros como e-ghim-eb-a 'sorrir', também podem significar a ocorrência de uma ação incontrolável (de rir ou sorrir, respectivamente), sem a intenção do participante dativo, no sentido de não poder ou conseguir controlar o riso ou sorriso.

Há também verbos indiretos que, derivados de adjetivos, expressam um julgamento ou opinião do participante dativo em relação ao nominal nominativo ter aquela qualidade expressa pela raiz do adjetivo (HEWITT, 1998):

\begin{tabular}{|c|c|}
\hline Verbos de julgamento: & Exemplos: \\
\hline $\begin{array}{l}e-a d v i l-e b-a \text { 'julgar/achar que } \\
\text { alguma coisa é fácil' } \\
\text { Cf. adjetivo: advil-i 'fácil' }\end{array}$ & $\begin{array}{l}\text { m-e-advil-eb-a - 'Eu } u_{\mathrm{DAT}} \text { acho que } \mathrm{X}_{\mathrm{NOM}} \text { é fácil.' } \\
\text { e-advil-eb-a - 'Ele/a acha que } \mathrm{X}_{\mathrm{NOM}} \text { é fácil.' }\end{array}$ \\
\hline $\begin{array}{l}e-\cot ^{\prime} a-v-e b-a \text { 'julgar/achar que } \\
\text { alguma coisa é pouco' } \\
\text { Cf. adjetivo: } \text { cot'a 'pouco' }^{-}\end{array}$ & $\begin{array}{l}\text { m-e-cot'a-v-eb-a - 'Eu } u_{\text {DAT }} \text { acho que } X_{\text {NOM }} \text { é pouco.' } \\
\text { e-cot'a-v-eb-a - 'Ele/a acha que } X_{\text {NOM }} \text { é pouco.' }\end{array}$ \\
\hline $\begin{array}{l}e \text {-jnel-eb-a 'julgar/achar que } \\
\text { alguma coisa é difícil' } \\
\text { Cf. adjetivo: } j n e l-i \text { 'difícil' }\end{array}$ & $\begin{array}{l}\text { m-e-jnel-eb-a - 'Eu }{ }_{\text {DAT }} \text { acho que } X_{\mathrm{NOM}} \text { é difícil.' } \\
\text { e-jnel-eb-a - 'Ele/a acha que } X_{\text {NOM }} \text { é difícil.' }\end{array}$ \\
\hline
\end{tabular}

Tabela 16: Verbos de julgamento em georgiano

\subsection{Discussão dos grupos semânticos}

A figura abaixo ilustra os grupos semânticos de verbos experienciais divisados na seção anterior e deve ser tomada apenas como um guia visual para referência.

Os grupos foram ligados por círculos menores para indicar continuidade, dessa forma, os círculos maiores não representam grupos discretos, mas sim formam entre si contínuos sem limites precisos.

Como argumentamos, esse contínuo se explica pelas semelhanças em significado entre esses grupos que, aliás, são salientes não só em georgiano, mas translinguisticamente, já que costumam apresentar uma marcação não canônica do experienciador em diversas línguas. As ditas semelhanças em significado consistem em extensões de determinadas noções que acreditamos motivar a marcação em comum, tais como afetação e não volicionalidade. 
Inicialmente, discutiremos cada grupo de verbos em georgiano e em outras línguas, apontando diferenças e semelhanças conceituais e estruturais importantes. Essa primeira discussão servirá de base para a caracterização conceitual no capítulo 7 que levará em conta os dados e conclusões tiradas na discussão dos grupos verbais.

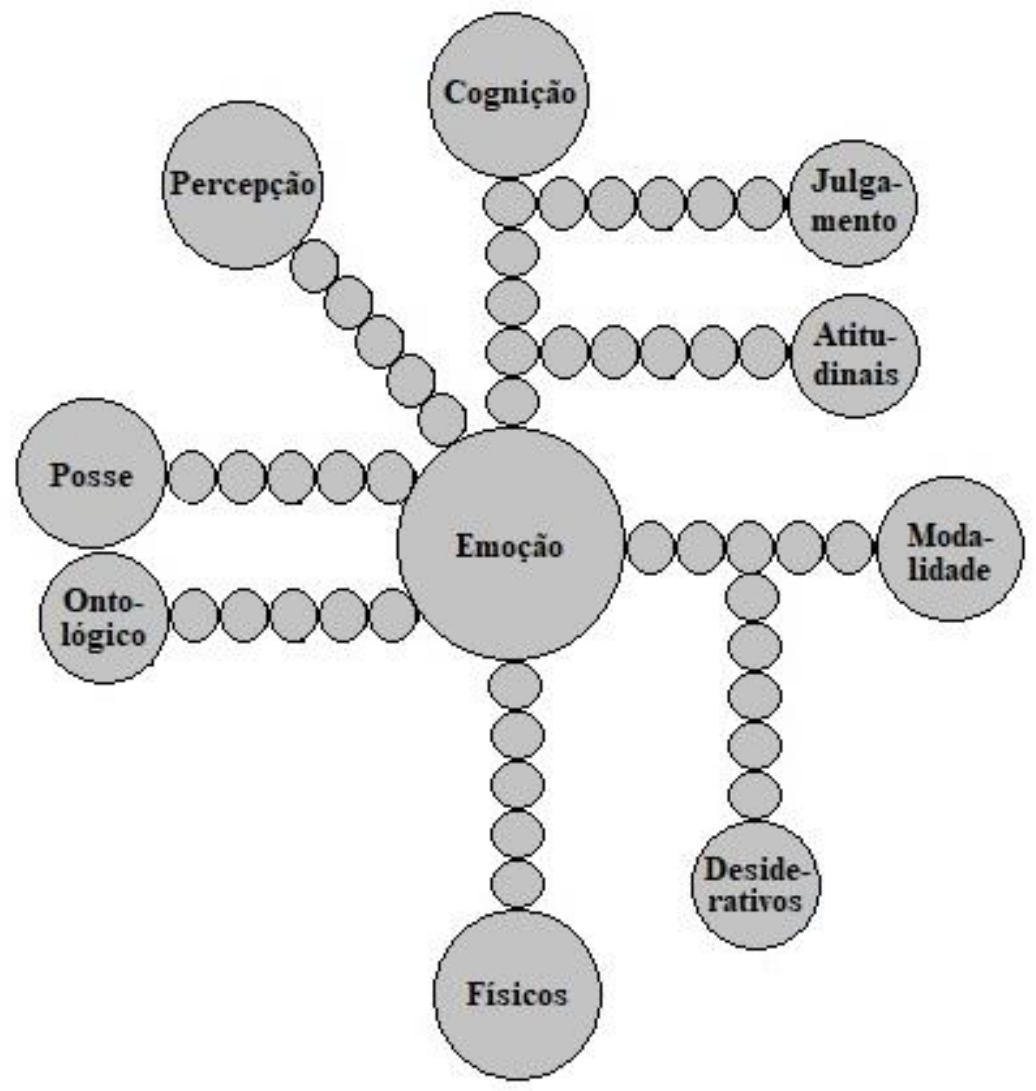

Figura 1: Verbos com marcação não canônica no georgiano com o experienciador no caso dativo.

Como pode ser observado pela figura, optamos por colocar os verbos que denotam emoções no centro da figura, essa escolha se deu mais em razão de esses verbos ocorrerem em maior número e de forma mais variada, isto é, englobam uma grande variedade de significados que vão desde os mais encontrados nas línguas como 'gostar', 'amar', 'querer', 'odiar' como mais periféricos como 'ver em sonho', 'estar com sorte'.

De qualquer forma, o que todos esses predicados têm em comum é o fato de denotarem eventos em que um de seus participantes é o experienciador de um evento mental de caráter experiencial e que ocorre na esfera íntima de seu psicológico e que não é diretamente acessível aos outros. E não menos importante, são eventos em que 
normalmente o experienciador não tem controle sobre, isto é, não controla sua ocorrência ou surgimento, tanto que essa emoção pode ser causada por algo que acontece externamente e que acaba afetando o experienciador positiva ou negativamente.

Note que essa caracterização não difere, de modo amplo, de um evento físico, já que estados físicos tais como dor, frio, sono, fome, sede, dentre outros, são sentidos dentro da esfera íntima do experienciador, não sendo acessíveis aos outros (a não ser por certas manifestações visíveis como um bocejo de sono, um tremor de frio, suor de calor). E na maior parte, constituem estados involuntários, necessidades fisiológicas sobre as quais o experienciador não tem controle.

De fato, em georgiano, eventos mentais e físicos são tratados da mesma forma, tanto em relação à marcação quanto à antiguidade de algumas de suas raízes, sendo assim difícil estipular qual tipo de evento seria mais básico em termos de marcação não canônica, isto é, qual seria mais propenso a essa marcação.

Essa discussão é importante visto que almejamos caracterizar conceitualmente eventos experienciais codificados com o caso dativo, e como o intuito é que essa caracterização possa ser também válida para outras línguas, discutiremos também dados de outras línguas. Como veremos na seção seguinte, há algumas diferenças entre eventos de emoção e eventos de sensação física.

\subsubsection{Verbos emocionais e físicos}

Como nota Malchukov (2005), diferentes autores que estudaram translinguisticamente o fenômeno de marcação não canônica, como Onishi (2001) e Haspelmath (2001), chegaram a conclusões distintas no que concerne a quais predicados teriam mais inclinação a serem marcados não canonicamente nas línguas. Onishi (2001), por exemplo, conclui que se uma língua tiver eventos de emoção marcados não canonicamente, provavelmente também terá eventos de sensação física marcados não canonicamente. $\mathrm{O}$ que equivale a dizer que predicados de sensação física têm uma maior tendência a receberem esse tipo de marcação, comparadamente a eventos de emoção. Já Haspelmath (2001), com base no estudo de Bossong (1998) sobre construções experienciais em línguas europeias, mostra que eventos de emoção teriam 
uma maior tendência a serem marcados não canonicamente, seguidos de eventos de sensações físicas que seriam intermediários entre eventos de emoção e eventos de percepção, estes mais propensos à marcação canônica nessas línguas.

Cada autor, no entanto, chegou a conclusões distintas baseadas em dados distintos.

Onishi (2001), em sua revisão acerca de marcação não canônica nas línguas, levou em conta principalmente dados de línguas estudadas no próprio volume sobre o tema. Dentre as línguas ali descritas, apenas uma delas, Tariana, parece marcar não canonicamente somente verbos de sensações físicas e não verbos de emoções (AIKHENVALD, 2001). As outras línguas apresentadas no volume, ou marcam não canonicamente os dois tipos (e.g. islandês, bengali), ou parecem marcar não canonicamente verbos de sensação física assim como verbos de emoção com um participante apenas e o verbo 'querer' (e.g. imbabura quéchua, amele).

Já Haspelmath (2001, mesmo volume) baseou-se no estudo de Bossong (1998) que investigou um conjunto de dez predicados em quarenta línguas da Europa, dentre línguas indo-europeias e não indo-europeias como georgiano e lezguiano, dando pontos em uma escala a cada predicado de acordo com a marcação encontrada. ${ }^{70}$ Haspelmath, somando esses índices para cada predicado, chegou a porcentagens que mostram maiores valores para verbos de cognição aparecendo com construções mais canônicas, e maiores valores para verbos de emoção aparecendo com construções que se desviam dessas construções. Verbos de sensação física teriam valores intermediários entre cognição e emoção. ${ }^{71}$

Essas diferentes conclusões baseadas em diferentes fontes atestam uma maior necessidade de se investigar um maior número de línguas levando em consideração um conjunto mais abrangente de predicados. Este último é particularmente difícil tendo em vista que muitas descrições não são completas, ou seja, o fato de um estudo apontar para a existência de determinados tipos de predicados marcados não canonicamente, não mencionando outros, não necessariamente significa que esses 'outros' também não sejam marcados em menor ou maior escala. Por vezes, a razão dessa omissão pode ser a

\footnotetext{
70 Os predicados são 'ver', 'esquecer', 'lembrar' (verbos de cognição), 'ter fome, 'ter sede', 'ter frio', 'ter dor de cabeça' (verbos de sensação física), 'estar feliz', 'sentir muito' e 'gostar' (verbos de emoção).

${ }^{71} \mathrm{~A}$ maior parte das línguas observadas mostrou uma mescla entre marcação canônica e não canônica dos predicados, pendendo para uma maioria desta ou daquela. A língua georgiana, aliás, teve uma pontuação de 13:40, o número treze se referindo a predicados marcados canonicamente e quarenta se referindo aos marcados não canonicamente.
} 
falta de mais dados daquela língua ou mesmo que o foco do autor não seja listar diferentes tipos de predicados, mas apenas exemplificar a ocorrência de determinada construção.

Qualquer que seja o motivo, há sempre o perigo de se tirar conclusões que não correspondem à realidade da língua ou de determinado grupo linguístico, principalmente aqueles grupos menos descritos e de mais difícil acesso a fontes variadas. E são justamente esses grupos de línguas, os menos descritos, que se necessita olhar para se ter uma real noção de determinado fenômeno linguístico, seu alcance e mesmo sua potencial universalidade.

Acreditamos, como Onishi (2001) menciona, que a maior parte das línguas que apresenta marcação não canônica vai marcar dessa forma tanto verbos de emoção quanto verbos de sensação como é o caso do georgiano, russo, islandês, de línguas dravídicas, dentre diversas outras. Se assim for o caso, aumenta ainda mais a necessidade de se buscar casos, principalmente de línguas menos descritas, que possam vir a confirmar ou alterar esse quadro, fazendo pender para a conclusão de autores como Onishi (2001) ou de Haspelmath (2001).

Comrie \& van den Berg (2006) em seu estudo sobre construções experienciais marcadas não canonicamente nas línguas nakh-dagestanianas ou leste-caucasianas (exceto as línguas nakh), nota o quanto o conhecimento de quais predicados participam dessa construção é limitado devido ao pequeno número de descrições abrangentes dessas línguas. ${ }^{72}$

Esse grupo linguístico é particularmente interessante, pois ocorre o chamado caso 'afetivo', usado especialmente para marcar construções experienciais nessas línguas. Na seção 6.4 e no capítulo 7 discutiremos a respeito dessas construções com o caso 'afetivo' (e locativos) e como se relaciona à nossa hipótese.

No momento, basta notar que o autor distingue quatro tipos de predicados que participariam de construções experienciais nessas línguas: verbos de emoção, verbos de percepção, verbos de cognição e verbos de atividade não intencional. É possível perceber que os verbos de sensação física não estão inclusos nessa relação, e embora o autor não explicite no texto que verbos de sensação física não são de fato marcados da

\footnotetext{
72 Apesar do nome similar, as línguas leste-caucasianas não são aparentadas com as línguas sulcaucasianas (ou kartvelianas) das quais o georgiano faz parte. O termo 'caucasiano' comum se refere à região do Cáucaso em que são faladas.
} 
mesma forma, seria possível deduzir por sua não listagem que eles são marcados diferentemente, talvez canonicamente.

Se assim fosse o caso, seria mais um dado confirmando em parte a conclusão de Haspelmath citada acima de que verbos de emoção teriam uma maior tendência de serem marcados não canonicamente do que verbos de sensação física.

No entanto, o artigo de Ganenkov (2006), que também estudou construções experienciais nas línguas leste-caucasianas, inclui um predicado de sensação física 'sentir frio' que seria marcado não canonicamente em algumas dessas línguas, tais como: agul, andi, archi, akusha dargi, godoberi, lak, ingush, tsakhur, lezguiano, tabasaran e tsez. Em lezguiano, aliás, além do predicado meq'ida 'ter frio', gishin 'fome' também teria o experienciador marcado com o caso dativo (HASPELMATH, 1993).

Mesmo não havendo menção a outros predicados de sensação física no artigo de Ganenkov (2006), é possível se questionar se não há mais predicados de sensação física tais como aquele, nas línguas em questão, que talvez não tenham sido levantados ou identificados, ficando mais difícil formar conclusões tipologicamente precisas com apenas um número pequeno de predicados.

Ainda assim, o fato de um número significativo de línguas dessa família marcarem o experienciador do verbo 'sentir frio' com o caso dativo, talvez seja, de fato, um indício de que essas línguas estão tratando da mesma forma eventos de sensação física e de emoção, tal como parece ser o caso da língua lezgiana.

Voltando ao caso da língua Tariana mencionado há pouco, a princípio, haveria mais línguas ativo-estativas, tais como ela, que apresentariam além de uma marcação cindida entre verbos intransitivos - i.e., aqueles marcados da mesma forma que objetos de transitivas e aqueles marcados da mesma forma que sujeitos de transitivas -, também teriam uma terceira marcação. Esta justamente marcando certos predicados experienciais.

Segundo Aikhenvald (1999; 2001), línguas norte-arawak como Warekena, Baré e Baniwa também apresentariam essa terceira marcação, constituindo uma pequena classe de verbos mentais e de sensação.

Em Tariana, verbos $S_{a}$, que teriam a mesma marcação de sujeitos de transitivas, apresentariam concordância, no verbo, marcada por um conjunto de prefixos. Já verbos $\mathrm{S}_{\mathrm{o}}$, sendo marcados da mesma forma que objetos de transitivas, não apresentariam, no verbo, nenhum conjunto de prefixos ou sufixos. A terceira marcação $\left(S_{i o}\right)$, por sua vez, 
também não apresentaria nenhum conjunto de prefixos ou sufixos no verbo. No entanto, em contraste com verbos $S_{o}\left(e S_{a}\right)$, esse grupo de verbos teria seus pronomes pessoais marcados pelo sufixo -na, marca esta também utilizada com recipientes e beneficiários.

Como mencionado, essa terceira marcação $\left(S_{\mathrm{io}}\right)$ engloba predicados de sensação física como (56b). Verbos de emoção como 'ter medo' e 'ter raiva' seriam marcados como $\mathrm{S}_{\mathrm{o}}$ (cf. 56a).

(56) a. Nuha keru-mha

1SG estar.com.raiva-PRES.NONVIS

Eu estou com raiva. (AIKHENVALD, 2001)

b. Sõme di-na unina-pidana

muito 3SGNF-OBJ ter.sede.REM.P.REP

Ele estava com muita sede. (AIKHENVALD, 2001) ${ }^{73}$

Em outras línguas, no entanto, essa terceira marcação (especialmente argumentos de verbos intransitivos) pode variar entre verbos de emoção e sensação, por vezes havendo certa sobreposição, em termos de tipos de predicados, principalmente entre aqueles marcados como objetos de transitivas e aqueles marcados com um caso oblíquo como o dativo. Por exemplo, saweru, uma língua yapen da Indonésia, possui uma terceira marcação com o caso dativo que marcaria verbos experienciais como ‘sentir-se sozinho’ (DONOHUE, 2004, 2008). Embora Donohue (2004, 2008) não liste quais outros predicados seriam marcados com essa terceira marcação, nota-se que a marcação mais 'estativa' de verbos intransitivos, i.e., aquela que marca igual a objetos de transitivas, apresenta tanto verbos de sensação física como 'ter sede' quanto verbos de emoção como 'sentir-se triste' (ver relação de verbos em Donohue (2001)). ${ }^{74}$

\footnotetext{
73 Glosas utilizadas pela autora: OBJ: objeto; AUG: aumentativo; PRES.NONVIS: presente não-visual; REM.P.REP: passado remoto reportado; NF: não-feminino.

${ }^{74}$ Certo cuidado, no entanto, deve ser tomado ao se considerar dados de línguas pouco descritas, principalmente quando mais de uma fonte não pode ser verificada como é o caso da língua saweru citada e kolana (língua da família alor-pantar falada na Indonésia). Kolana, por exemplo, é citada por Donohue $(2001 ; 2004 ; 2008)$ como tendo três marcações distintas de concordância em verbos intransitivos (marcas essas rotuladas pelo autor, respectivamente, ora como 'absolutivo', 'acusativo' e 'dativo' (DONOHUE, 2001), ora como absolutivo I, II e III (DONOHUE, 2004, 2008). Entretanto, o estudo posterior de Schapper \& Hendery (2014) sobre a língua mostra a necessidade de um exame mais
} 
A mesma sobreposição parece ocorrer em outras línguas como em koasati e choctaw (línguas muscogees do sudeste do EUA). Em koasati - uma língua, a priori, ativo-estativa - haveria três marcações diferenciais de concordância em verbos intransitivos: o conjunto agentivo que marcaria verbos como 'ir'; o conjunto ca(estativo-pacientivo); e o conjunto am- (estativo-dativo) (KIMBALL, 1991). O conjunto ca-, além de marcar verbos não agentivos como 'cair', também apresentaria verbos de emoção como 'estar sozinho' e de estado físico como 'estar doente'. O conjunto am-, por sua vez, marcaria também verbos de emoção e sensação física como 'sentir-se deprimido' e 'sentir fome' respectivamente.

Situação similar se apresenta em choctaw que, segundo Broadwell (2006) e Donohue (2001), poderia codificar o único argumento de verbos intransitivos de três formas: através do conjunto I de concordância em verbos mais agentivos como 'correr', do conjunto II, marcando verbos estativos como 'estar quente' e também experienciais como 'estar com medo' e 'ter fome', e o conjunto III, marcando outros verbos experienciais como 'sentir-se bem' e 'sentir frio'.

Em suma, nota-se que as marcações diferenciais observadas em relação a verbos intransitivos apresentam certa sobreposição de grupos semânticos, principalmente em relação à marcação, no verbo, pacientiva e dativa nessas línguas. Tanto que, tanto em uma quanto em outra marcação, percebe-se a presença de verbos de emoção e sensação física, situação diferente da observada em Tariana que separa de forma mais marcante verbos de emoção e de sensação física, reservando a marcação dativa para estes últimos.

É interessante que, como nota Aikhenvald (2001) acerca da língua, certos predicados tais como macha 'ser bom', ma:chi 'ser mau' podem ser tanto marcados como $S_{o}$ quanto $S_{\mathrm{io}}$, havendo mudança de significado. Quando marcados por $\mathrm{S}_{\mathrm{io}}$, denotariam uma condição física do participante, quando marcados por $\mathrm{S}_{\mathrm{o}}$ descreveriam uma propriedade do participante.

Em outras línguas, como saweru, koasati e choctaw acima citadas, a terceira marcação, normalmente rotulada de dativa, não parece distinguir entre verbos de sensação física e emoção. O que se sobressai, aliás, nesses casos, e importante para este trabalho, é que, apesar da sobreposição desses predicados com outras marcações (i.e., verbos experienciais não são exclusivos da marcação dativa), há uma aparente

criterioso e aprofundado, pois, nos dados de campo coletados, os autores somente encontraram de fato um conjunto de marcas de concordância a que se refere Donohue (absolutivo I); os demais, um não constituiria morfemas presos de concordância, mas sim pronomes livres oblíquos, e o outro não foi encontrado no corpus coletado. 
homogeneidade no tipo de verbo que é encontrado nessas línguas com essa terceira marcação, sendo a maior parte, senão todos, verbos experienciais (de emoção ou físicos).

O que pode ser mais um ponto a favor para se dizer que as línguas, no geral, parecem não fazer distinção entre esses dois tipos de eventos experienciais, tendendo a tratá-los da mesma forma, seja com uma marcação diferencial para os dois ou não.

Diferentemente de Tariana, em que a mudança de conjunto de concordância gera uma mudança de significado entre verbos como 'ser bom' e 'ser mau' que de uma interpretação de condição física passa a denotar uma propriedade do experienciador, em muitas línguas parece haver uma ambiguidade em termos de forma entre predicados que podem ser usados com sentido mais emocional ou mais físico, sendo comum uma extensão desse sentido mais físico e mais concreto ao sentido mais emocional e mais abstrato.

Eventos como 'estar bem', 'estar mal', 'sentir dor', 'sentir cansaço' são exemplos desse tipo de predicado. Em português, por exemplo, esses predicados podem tanto ser tomados como mais físicos ou como mais emocionais a depender do contexto, observe os exemplos a seguir com verbos como 'sentir dor, doer' e 'sentir cansaço, cansar':

(57) a. Nada na vida me doeu mais do que essa notícia.

b. Ainda sinto dor pelas tantas que ela me fez, mas tenho pedido a Deus e à minha Nossa Senhora que me ajudem a não guardar mágoas em meu coração.

c. Ela perdeu a confiança em mim e eu me cansei de ser humilhado por ela.

d. A depressão hoje pra mim é algo que consigo dominar, mas estou sentindo outros sintomas além da tristeza. Sinto cansaço, físico e emocional e um certo medo.

e. Mal sabiam eles a dor que ele passava por ser sozinho e diferente.

f. Esta tem sido uma tremenda semana para mim. Estou cansado. Minha mente está cansada.

g. Meu corpo está cansado, minha mente está cansada. Aquela vontade de comer voltou, e pior: de comer besteira. 
Em (57a e b), a dor a que se refere o falante é psicológica e não física, assim como o cansaço em (57c) também advém de um estado mental do experienciador. Em (57d), é interessante que o cansaço como sendo físico, assim como emocional, é especificado lexicalmente, salientando a natureza diversa do evento experiencial.

Em (57e) é dado um exemplo de um substantivo, 'dor', usado com sentido emocional.

Em (57f e g), a natureza mental do evento de cansaço é especificada na forma de localizar o dado estado na 'mente' do experienciador, ou em seu 'corpo', i.e., a 'mente', como algo separado do corpo, vira o locus onde o estado psicológico (e não como sensação física) ocorre e de onde se origina. Essa estratégia é frequentemente comum nas línguas, cada qual usando partes do corpo por vezes distintas para localizar as emoções (ver discussão logo a seguir).

Em georgiano, situação similar se apresenta. Observe que os exemplos em (58a e b) trazem o verbo $t^{\prime} k$ 'iva 'sentir dor' em seu sentido físico:

a. rat'om s-t'k'iv-a-t bavshv-eb-s mucel-i?

por que 3BDAT-sentir.dor-3ANOM-PL criança-PL-DAT estômago.NOM Por que as crianças sentem dor no estômago ${ }^{76}$

b. mamachemi aris 71 c'lis da s-t'k'iv-a pex-eb-i meu.pai.NOM COP.3SG 71 anos e 3BDAT-sentir.dor-3ANOM perna.PL.NOM Meu pai tem 71 anos e sente dor nas pernas. ${ }^{77}$

\footnotetext{
${ }^{75}$ Fontes correspondentes a cada exemplo, respectivamente: http://revistasorria.com.br/site/edicao/o-que-nos-cabe.php http://minhamaetemdepressao.wordpress.com/about/ vilamulher.terra.com.br http://www.escolapsicologia.com/porque-e-que-nao-consigo-ser-feliz/ http://www.escolapsicologia.com/porque-e-que-nao-consigo-ser-feliz/ blog-br.com extra.globo.com ${ }^{76}$ Fonte: www.vidal.ge/health/

${ }^{77}$ Fonte: https://forum.ge/?showtopic=34295043
} 
O experienciador, aquele que sente a dor física ('criança' em (a) e 'meu pai' em (b), correferencial com o argumento dativo omitido da segunda oração), está no caso dativo e o local do corpo onde a dor ocorre está no caso nominativo ('estômago' e 'pernas').

O mesmo verbo também pode ser usado se referindo à dor emocional:

(59)
a. rodesac chven gv-t'k'iv-a, mas-ac
quando 1PL.DAT 1BDAT.PL-sentir.dor-3ANOM 3SG.DAT-também
s-t'k'iva.
3BDAT-sentir.dor-3ANOM
Quando nós sentimos dor, ele também sente dor. ${ }^{78}$

b. bunebrivi-a, gv-t'k'iv-a, roca saqvarel-i adamian-i natural.COP 1BDAT.PL-sentir.dor-3ANOM quando amado-NOM pessoa-NOM xeli-dan gv-e-cl-eb-a, magram uimedoni ar mão.POSP 1BDAT.PL-VPR-escorregar-ST-3ANOM mas sem.esperança não vart.

COP.1PL

É natural, nós sentimos dor quando pessoas amadas escorregam de nossas mãos (morrem), mas nós não ficamos sem esperança. ${ }^{79}$

Note que ambos os exemplos em (59) se referem à dor como sofrimento emocional, não havendo diferença na forma verbal empregada e na marcação de seus argumentos.

Essa versatilidade de certos predicados de serem empregados ou com sentido físico ou emocional também pode ser observada em verbos no georgiano que não marcam o experienciador com o caso dativo. É o caso do verbo $i$-ghl-eb-a 'ficar cansado, cansar' de morfologia de Classe II:
(60) a. me da-v-i-ghal-e, da dac'ola m-i-nd-a
1SG.NOM PV-1ANOM-VPR-cansar-AOR e deitar 1BDAT-VPR-querer-3ANOM
Eu fiquei cansado e quero deitar. ${ }^{80}$

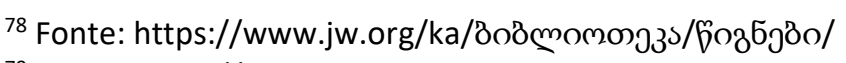

${ }^{79}$ Fonte: https://wol.jw.org/wolılp-ge

${ }^{80} \mathrm{https}: / /$ ka.glosbe.com/ka
} 
$\begin{array}{llll}\text { b. me } & \text { da-v-i-ghal-e, } & \text { chemi } & \text { problem-eb-it } \\ \text { 1SG.NOM } & \text { PV-1ANOM.SG-VPR-cansar-AOR } & \text { meu } & \text { problema-PL-INSTR }\end{array}$

Eu me cansei dos meus problemas. ${ }^{81}$

Nos dois exemplos, o experienciador está no caso nominativo. No primeiro, o verbo denota o cansaço como físico, tanto que há a necessidade de se deitar e descansar. Já no segundo, o cansaço é mental e decorre de uma fonte que não afeta o experienciador fisicamente, mas sim mental ou emocionalmente (seus problemas).

Assim como o caso visto em português em ( $57 \mathrm{f}$ e g), em que uma parte do corpo é usada para localizar a experiência e especificar sua natureza, em georgiano também é possível ver exemplos desse tipo. Observe:

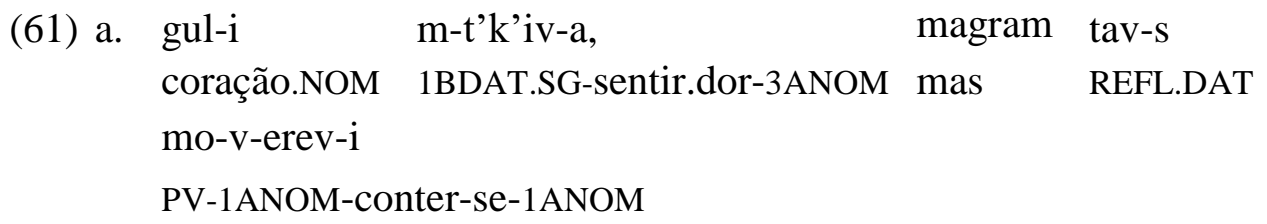

Meu coração dói (sinto dor no coração), mas estou me contendo. ${ }^{82}$

b. gul-i m-t'k'iv-a, roca p'ablo chem-s coração-NOM 1BDAT-sentir.dor-3ANOM quando p'ablo.NOM meu-DAT shvil-eb-s mk'acrad e-kcev-a filho-PL-DAT duramente VPR-tratar-3ANOM Meu coração dói (sinto dor no coração) quando Pablo trata meus filhos duramente. $^{83}$

Os exemplos mostram o verbo t'k'iva 'sentir dor' com o significado de dor ou sofrimento emocional experienciado pelo participante no caso dativo. O substantivo no nominativo guli 'coração' é usado para localizar a experiência, indicando metaforicamente uma dor emocional.

Dessa forma, há expressões nas línguas que podem adquirir significados que denotam particularmente estados emocionais e mentais, justamente para especificar essa

\footnotetext{
81 https://wol.jw.org/ka/wol/d/r20/lp-ge/102008409

82 https://wol.jw.org/ka/wol/d/r20/lp-ge/102009051

83 https://wol.jw.org/ka/wol/d/r20/lp-ge/102012121
} 
sua natureza em contraste com seu sentido original mais físico, tanto no que se refere à parte do corpo, conceitualizada metaforicamente como o locus de onde a emoção se origina, quanto ao uso de verbos de sensação física com sentido mais emocional ou mental.

Assim, na mesma medida em que um mesmo verbo pode ser usado com sentido mais emocional ou físico a depender do contexto, há frequentemente o desenvolvimento de expressões, com partes do corpo por exemplo, que são usadas metaforicamente para especificar a natureza da emoção, se física ou emocional, como o seu locus.

Daí um fato tipologicamente frequente em que partes do corpo são gramaticalizadas como parte de expressões ou mesmo de formas verbais que denotam estados psicológicos.

Por exemplo, nas línguas muscogee (como chickasaw, choctaw, alabama, koasati e creek), vocábulos reconstruídos em proto-muscogee como substantivos independentes tais como *nok- 'garganta, pescoço' desenvolveram usos, como afixos nas línguas modernas, que se referem a emoções (HAAS, 1941; SCANCARELLI \& HARDY, 2005).

Em choctaw, segundo Haas (1941), esse afixo é encontrado em diversos verbos que denotam emoções como: nokha.nklo 'sentir muito', nokwilo.ha 'estar triste', nokwannichi 'tremer por medo' (cf. wannichi 'tremer'), nokshobli 'assustar, intimidar', noklibisha 'estar apaixonado' (cf. libisha 'ficar quente'), nokpalli 'estar interessado, entusiasmado', noktala 'ter ciúmes', nokhobi.la 'estar irritado, com raiva' (em koasati: noksi.pa 'ficar irritado'), noktala.li 'ficar tranquilo' (cf. tala.li 'colocar uma coisa'). ${ }^{84}$

Já em creek, é encontrado o substantivo incorporado fik- 'coração' em verbos psicológicos (HAAS, 1941): fiknokkitá 'ficar triste' (cf. nokk-itá 'ficar doente'), fikcakhitá 'ficar enciumado' (cf. cakh-itá 'ficar preso em'), fiksomkitá 'ficar assustado' (cf. somk-itá 'perder-se), fikhamkitá 'tornar-se bravo, corajoso'. ${ }^{85}$

Vimos até agora que certos predicados em algumas línguas podem ser usados tanto física quanto emocionalmente sem diferenças na forma do verbo. Fato que não

\footnotetext{
${ }^{84}$ No inglês, segundo Haspelmath (2001), o verbo worry 'preocupar', assim como outros, desenvolveuse a partir de verbos concretos como 'estrangular, segurar pela garganta', é interessante notar a parte do corpo 'garganta' também conceitualizada como locus da emoção.

85 Algumas expressões com partes do corpo também desenvolveram-se em significados denotando sensações físicas específicas, por exemplo, em choctaw: nokshila 'ter sede' em que shila significa 'secar, estar seco'; nokpowalli 'sentir-se enjoado' em que powalli significa 'causar ondas'. Em relação a esse último, há exemplo similar no georgiano usando-se a parte do corpo guli 'coração': guli m-e-reva 'eu me (dat.) sinto enjoado, sinto ânsia' em que o verbo rev-s significa 'misturar, bagunçar'.
} 
impede que haja expressões que especifiquem qual é o sentido a ser dado, se físico ou emocional, por exemplo, quando usadas partes do corpo que se tornam o locus da emoção. O que, como vimos, pode inclusive sofrer gramaticalização nas línguas.

Além da observação de que nas línguas há essa versatilidade no uso de certos predicados com sentido físico e emocional, nota-se que no georgiano, assim como em outras línguas, há a ocorrência de um verbo de significado mais abstrato ou geral quanto ao tipo de evento experiencial e quanto à natureza desse evento, se físico ou mental: o verbo 'sentir'.

Note que esse verbo não especifica o tipo de evento experiencial, seu sentido completo dependendo de um complemento. E o mais interessante para a presente discussão é que, nas línguas em que aparece, não distingue entre eventos físicos ou emocionais. Em termos de conceitualização, é um dado importante, pois indica que eventos físicos e emocionais estão sendo tratados da mesma forma, isto é, podemos 'sentir' emoções, assim como 'sentimos' sensações físicas.

No georgiano, o verbo grdznob 'sentir' tem morfologia de Classe 3, tendo, portanto, o experienciador marcado com o caso nominativo no presente e ergativo no aoristo. Observe os exemplos abaixo:

(62) a. bavshv-i daghlil-i xom ar aris am tav-s cudad criança-NOM cansada-NOM ou não 3SG.COP isso REFL-DAT mal xom ar grdzn-ob-s? ou não sentir-ST-3ANOM.SG

A criança está cansada ou se sente mal? ${ }^{86}$

b. axlac sist'emat'urad v-varjim-ob, ainda regularmente 1ANOM-exercitar-ST mashinac k'i, rodesac daghliloba-s v-grdzn-ob, mesmo quando

cansaço-DAT 1ANOM-sentir-ST radgan es

gamojanmrteleba-shi m-e-xmar-eb-a recuperação-POSP 1BDAT-VPR-ajudar-ST-3ANOM

Eu ainda me exercito regularmente, mesmo quando sinto cansaço, porque isso me ajuda na recuperação. ${ }^{87}$

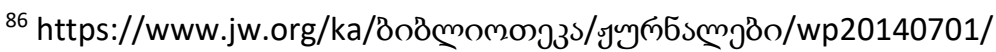

87 https://wol.jw.org/ka/wol/d/r20/lp-ge/102002527 
Em (62a), o verbo 'sentir' é acompanhado pelo advérbio cudad 'mal' que, pelo contexto, sabe-se que se refere ao fato de o experienciador se sentir mal fisicamente. Em (62b), o verbo 'sentir' é acompanhado pelo complemento direto que denota a sensação física daghliloba 'cansaço'.

Esses exemplos podem ser contrastados com os exemplos em (63) abaixo:

(63) a. tav-s dzalian bednierad v-grdzn-ob

REFL-DAT muito feliz 1ANOM-sentir-ST

Eu me sinto muito feliz. ${ }^{88}$

b. chven mravali ramis gamo v-grdzn-ob-t madliereba-s 1PL.NOM muito coisa.GEN devido 1ANOM-sentir-ST-PL gratidão-DAT Nós sentimos gratidão por muitas coisas. ${ }^{89}$

Em (63a), o verbo 'sentir' é acompanhado do advérbio bednierad 'feliz' denotando o estado emocional do experienciador. Em (63b), o verbo 'sentir' é acompanhado por um complemento direto, o substantivo madliereba 'gratidão', codificando o estado de espírito do experienciador.

Em russo, uso similar também é encontrado, em que o verbo 'sentir', chuvstvovat', pode ser tanto usado para indicar emoções (64b) quanto sensações físicas (64a):

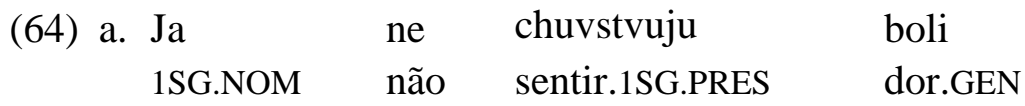

Eu não sinto dor. (RYLINA, 2013, p. 19)

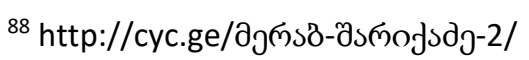

${ }^{89}$ https://www.churchofjesuschrist.org/study/liahona/2016/11/ 


\author{
b. Ona chuvstvovala volnenie pri mysli o \\ 3SG.NOM sentir.3SG.PAST ansiedade.ACC ao pensamento sobre \\ Vronskom \\ Vronsky.PREPOS \\ Ela sentiu ansiedade ao pensar em Vronsky. (RYLINA, 2013, p. 19)
}

Em Tariana, talvez fosse esperado que, existindo um verbo denotando 'sentir', este seria ou lexicalmente especificado (i.e., verbos diferentes para sensações físicas e emoções) ou que haveria alguma diferença gramatical em termos de marcação. No entanto, nenhuma das alternativas parece se verificar.

Aikhenvald (2003) reporta haver dois predicados em Tariana que significariam 'sentir', -himeta e -rena, sendo os dois prefixados (i.e., marcados como verbos A e $\mathrm{S}_{\mathrm{a}}$ ).

Pelos exemplos dados pela autora $(2002 ; 2003)$, o verbo -himeta parece poder aparecer, como verbo secundário, tanto com verbos de sensação física quanto mentais/emocionais:

- kasitana dhimeta 'ele sente inveja, aborrecimento'

- kawalikupeda dhimeta 'ele sentiu tristeza'

- kapemanina dhimeta 'ele sentiu vergonha'

- mhaisiki dhimeta 'ele sentiu fome'

- weperi nuhmeta 'eu senti febre'

- kai nuhmeta 'eu senti dor'

O verbo -rena, por sua vez, parece ocorrer, quando verbo secundário, mais com verbos com sentido de sensação física como ma:chi 'ruim' e macha 'bom':

(65) a. ma:chi-pu-mha nu-rena

Eu me sinto fisicamente doente. (AIKHENVALD, 2003, p. 298)

No entanto, o verbo -rena parece também ocorrer com um verbo emocional kapemani 'envergonhar': [...] kapemani na-rena-ka 'eles sentem vergonha' (AIKHENVALD, 2003, p.189). 
Os dados vistos até aqui apontam para uma neutralidade do verbo 'sentir' em relação a sensações físicas e emoções em línguas de famílias variadas, o que pode indicar que esses dois tipos de eventos experienciais são conceitualizados de forma similar ou que são percebidos como tendo características conceitualmente salientes em comum, o que frequentemente os faz serem agrupados juntos em termos de marcação.

Uma diferença importante, no entanto, entre eventos emocionais e de sensação física é a capacidade dos primeiros de poderem ser dirigidos a outro participante, i.e., temos a capacidade de direcionar nossos pensamentos e emoções para outros, fazendo deles objetos ou alvos dessas emoções, o que não ocorre em eventos de sensação física.

Decorre dessa característica, como nota Malchukov (2005), a tendência de verbos de sensação física serem mais intransitivos nas línguas, codificando apenas um participante.

De fato, se pensarmos no estudo de Hopper \& Thompson (1980), que considera transitividade como uma propriedade que engloba toda a sentença e, portanto, uma questão de gradação envolvendo diversos parâmetros, verbos de sensação física seriam fortes candidatos à baixa transitividade, levando-se em consideração não só parâmetros como baixa volicionalidade e agentividade, mas também a presença de apenas um participante no evento. Fator este que poderia ajudar a pender a balança para uma marcação não canônica mais frequente desses verbos em contraste com verbos de emoção com dois participantes.

No entanto, verbos de emoção também podem ser codificados com apenas um participante (experienciador), nesse caso, poderiam ter a mesma tendência maior, acima citada, de terem uma marcação não canônica tal como verbos de sensação física, o que explicaria dados de línguas como imbabura quéchua e amele que marcariam não canonicamente apenas verbos de sensação física e verbos de emoção com um participante (ONISHI, 2001).

Ainda assim, acreditamos que o quadro é um pouco mais complexo, já que o número de participantes, em relação à diferenciação entre verbos de emoção e físicos, nem sempre parece ser evidente nas línguas.

Em georgiano, assim como em outras línguas, muitos verbos experienciais podem tomar opcionalmente um segundo argumento, sendo por vezes difícil rotular o verbo como 'mono' ou 'bivalente'.

Verbos que são frequentemente citados na literatura como tendo apenas um participante, como aqueles citados por Onishi (2001) como 'estar triste', 'ter raiva', 'ter 
vergonha', 'estar surpreso', podem em muitas línguas codificar um segundo participante, o estímulo. Em georgiano, esse segundo participante normalmente está no caso nominativo (ou genitivo), o verbo $u$ - $k$ 'vir-s 'estar surpreso', por exemplo, pode ocorrer com um estímulo no caso nominativo:

(66) a. misi p'erpormansi ar m-i-k'vir-s dele.NOM performance.NOM não 1BDAT-VPR-estar.surpreso-3ANOM.SG

Eu não estou surpreso com sua performance. ${ }^{90}$

Em outras línguas, como koasati, também são encontrados verbos com valência variável. Os verbos transitivos com marcação estativa hó:pan 'estar doente', ilhó:sin 'esquecer', l'ákcan 'ter nostalgia, ter saudades de casa', ofáhyan 'ter vergonha' podem tanto ser usados transitivamente, com dois argumentos, quanto intransitivamente (KIMBALL, 1991). O verbo hó:pan 'estar doente', quando usado transitivamente, adquire o significado de 'odiar'.

Mesmo predicados considerados como invariavelmente transitivos ou intransitivos, podem acabar sendo usados mais transitiva ou intransitivamente em determinados contextos. Cherchi (1997), por exemplo, fornece um exemplo do verbo $u$ qvar-s 'amar' em georgiano sendo usado intransitivamente:

(67)

\begin{tabular}{|c|c|c|c|c|}
\hline $\begin{array}{l}\text { gul-s } \\
\text { coração.DAT }\end{array}$ & $\begin{array}{l}\text { manamde } \\
\text { até.então }\end{array}$ & $\begin{array}{l}\text { u-qvar-s } \\
\text { VPR-amar-3ANOM.SG }\end{array}$ & $\begin{array}{l}\text { sanam } \\
\text { até }\end{array}$ & $\begin{array}{l}\text { tavis } \\
\text { próprio }\end{array}$ \\
\hline dzaleb-s & ar & da-xarj-av-s & & \\
\hline força-DAT & não & PV-perder-ST-3ANO & & \\
\hline
\end{tabular}

Em outros casos, um verbo considerado normalmente intransitivo, como c'quria 'ter sede', pode ser encontrado sendo usado transitivamente: ${ }^{91}$

\footnotetext{
${ }^{90}$ Fonte: reali.ge/samefo-tasi/1813--.html

$91 \mathrm{Em}$ português, exemplos com sentido parecido a (68) podem ser encontrados como 'ter sede de sangue', 'ter sede de poder', nesses casos, assim como no exemplo em georgiano, o complemento
} 
(68) a. c'qal-i m-c'ur-i-a

água-NOM 1BDAT-ter.sede-ST-3ANOM

Eu tenho sede de água. (CHERCHI, 1997, p. 16)

Embora acreditamos que o número de argumentos seja um parâmetro importante para a baixa transitividade de verbos experienciais e consequentemente, para sua tendência à marcação não canônica, não nos parece evidente que o número de participantes seja um parâmetro relevante para diferenciar verbos de emoção e verbos de sensação física, de forma a explicar a maior tendência de um ou de outro a aparecer com marcação não canônica.

Diacronicamente, em algumas línguas, é possível traçar uma origem intransitiva para verbos de emoção com dois argumentos com o experienciador marcado não canonicamente (normalmente oblíquo), o que tornaria difusa uma diferenciação com base no número de argumentos entre verbos de sensação física e verbos de emoção.

Em koasati, por exemplo, alguns verbos transitivos marcados estativamente como stimayókpan 'amar', stificcákkin 'ter ciúmes' e sti'hawá:lon 'ter pena' foram derivados historicamente de outros verbos intransitivos de mesma raiz através do prefixo instrumental st-/s- (KIMBALL, 1991). Esse dado possivelmente indica que o instrumental pode ter sido utilizado para codificar um segundo participante oblíquo, com o tempo se gramaticalizando na estrutura desses verbos e perdendo o sentido de instrumental propriamente.

Embora uma busca sistemática tipologicamente deva ser feita para se ter certeza, parece-nos, com base nos dados que temos visto até aqui, que há uma tendência, nas línguas, a tratar eventos emocionais da mesma forma que eventos de sensação física, o que muitas vezes favorece extensões destes para aqueles. Casos de especialização semântica também podem ser encontrados, em que certas partes do corpo são conceitualizadas como o locus da emoção.

Do ponto de vista da conceitualização e da codificação dos eventos experienciais, essa tendência é bastante interessante e intrigante, pois as línguas, ao qualifica o evento de 'ter sede'. 
codificar eventos de sensação física e de emoção de forma similar, apontam para a existência de aspectos similares na conceitualização desses dois tipos de eventos. ${ }^{92}$

Naturalmente, isso não quer dizer que eventos de sensação física e de emoção sejam conceitualizados de forma idêntica, mas que certos aspectos similares da conceitualização desses eventos são salientes o suficiente para que sejam codificados de forma similar, justamente enfatizando esses aspectos mais salientes.

As diferenças, aliás, que poderiam eventualmente ser apontadas não parecem se destacar nas línguas tal como as similaridades.

Por exemplo, a já citada diferença em eventos de emoção de poderem ser dirigidos a outro participante, o estímulo, o que não acontece em eventos de sensação física, já que não podemos dirigir necessidades fisiológicas como sono, fome ou mesmo dor física a outras entidades da mesma forma como dirigimos nossa raiva, amor ou ódio a outras coisas ou pessoas como objetos ou alvos dessas emoções.

No entanto, esse fator não parece ser saliente o suficiente para diferenciar esses dois tipos de eventos em termos de codificação, parecendo ser uma opção natural disponível na codificação de eventos emocionais.

Outro aspecto de diferenciação, é a relativa concretude das sensações físicas visà-vis a eventos emocionais. Ponsonnet (2014), por exemplo, ao estudar a linguagem emocional em dalabon, uma língua falada na Austrália, faz uma diferenciação entre eventos de sensação física e emocionais:

Emotional states differ from sensations and other affects in that they are triggered by representations of the world. Sensations, on the contrary, result from physical triggers. Emotions are triggered by the cognitive appraisal of events - social or otherwise. Sensations such as pain, hunger, tickling, etc., involve no cognitive grasp: I can feel pain in my hand without establishing a representation of the source of the pain. (PONSONNET, 2014, p. 13)

Por esse lado, sensações físicas possuiriam uma base mais concreta, já que necessidades fisiológicas como sono, fome e sede, assim como dor, uma coceira, frio ou calor são reações ou respostas do próprio corpo a causas concretas ou naturais, não

\footnotetext{
${ }^{92}$ Como tendências dificilmente são absolutas, desvios podem ser esperados, podendo salientar algum aspecto distinto na conceitualização de eventos de sensação física e de emoção. Resta saber, se casos como os de Tariana estariam de fato enfatizando alguma diferença entre eventos de sensação física e de emoção. A resposta talvez sendo mais apropriadamente encontrada em uma busca mais detalhada língua-internamente ou em casos similares translinguisticamente.
} 
ocorrendo, a priori, somente na mente do experienciador. Já emoções, como a autora argumenta acima, ocorreriam em parte como uma resposta cognitiva a certos eventos e à sua 'representação' mental, constituindo eventos mais abstratos.

Por outro lado, apesar de eventos de sensação física terem uma base relativamente mais concreta, são eventos sensório-cognitivos na medida em que ocorrem na esfera íntima do experienciador e são processados cognitivamente. Nesse ponto, não diferem de eventos emocionais, já que também são inacessíveis aos outros e normalmente são involuntários, não podendo ser controlados pelo experienciador. ${ }^{93}$

E de fato, quando são marcados de forma similar nas línguas, o que parece mais saliente na conceitualização desses eventos são justamente essas características em comum: eventos que acontecem na esfera íntima do experienciador, sendo apenas 'sentidos' pelo experienciador; eventos não controláveis e não intencionais, tanto que podem ser 'causados' por eventos externos (sejam eles mais abstratos ou concretos); eventos que favorecem uma conceitualização que toma o experienciador como o local espacial onde ocorre a emoção e de onde ela surge, sendo esse local, por vezes, metonicamente tido como uma parte de seu corpo.

\subsubsection{Verbos de cognição e percepção}

Como é notado na literatura, verbos de cognição e percepção frequentemente são assimilados por construções mais canônicas nas línguas, como a transitiva (cf. HASPELMATH, 2001; MALCHUKOV, 2005; VERHOEVEN, 2007; FEDRIANI, 2014). Assim, relativamente a verbos de emoção e de sensação física, verbos de cognição e percepção seriam menos propensos à marcação não canônica.

Essa apontada tendência é usualmente atribuída à característica de experienciadores de eventos perceptivos e cognitivos de serem mais volitivos e terem mais controle sobre o processo, sendo menos afetados, já que reagiriam ao estímulo de forma mais racional (KEMMER, 1993; VERHOEVEN, 2007; FEDRIANI, 2014)

\footnotetext{
${ }^{93}$ Interessantemente, em Tariana, os evidenciais não visuais são também usados com verbos de atividade mental, de emoção, de sensação física, cognição e obrigação, além de também sinalizarem ações incontroláveis acidentais (AIKHENVALD, 2001, p. 298). Esse dado é importante, pois indica mais uma vez que eventos emocionais estão sendo tratados de forma similar na língua a eventos de sensação física.
} 
Em georgiano, no entanto, assim como em línguas não aparentadas a ele como islandês, línguas dravídicas, indo-arianas e leste-caucasianas, verbos de percepção e de cognição são marcados não canonicamente.

Abaixo, alguns exemplos de predicados de cognição em línguas distintas, englobando predicados tais como entender, saber, esquecer, lembrar, pensar, etc. Em islandês:

(69) a. mér var pað efst í huga pegar... 1SG.DAT era 3SG.NOM acima em mente quando

Eu me lembrei disso principalmente quando... (Barðdal, 2011, p. 65)

Em línguas dravídicas como kannada e malaiala, respectivamente:

(70) a. avanige í suddi tiLiyitu 3SG.DAT esse notícias vir.a.saber.NEUT

Ele veio a saber das notícias. (Sridhar (1979) apud Onishi (2001, p.29))

b. jooNinA billine ariyaam

John.DAT Bill.ACC conhecer

John conhece Bill. (Verma \& Mohanan, 1990, p.6)

Em línguas leste-caucasianas como hunzib:

(71) di'i r-iq'-at'.

1SG.DAT V-saber.PRES.NEG

Eu não sei. (Comrie \& van den Berg, 2006, p.130) ${ }^{94}$

\footnotetext{
${ }^{94}$ Em algumas línguas leste-caucasianas como bagvalal, godoberi e avar, há uma marcação cindida não canônica entre verbos experienciais, principalmente entre 'querer/amar' e outros verbos experienciais, como de cognição (entender, saber) e percepção (ouvir, ver), sendo o primeiro marcado com o caso dativo e os segundos com um caso locativo ou o caso chamado de 'afetivo' (Comrie \& van den Berg, 2006; Ganenkov, 2006).
} 
Em seguida, exemplos de verbos de percepção marcados não canonicamente em algumas dessas línguas, e que incluem verbos relativos aos sentidos: audição, visão, tato, olfato e paladar. Em islandês:

(72) mér smakkaðist hákarlinn vel

1SG.DAT experimentar tubarão.NOM bem

Eu gostei do gosto do tubarão fermentado (lit.: the shark tasted good to me). (Barðdal, 2011, p. 65)

Em cingalês (língua indo-ariana):

(73) mat'A horaawA penuna

1SG.DAT ladrão.ACC ver.PAST

Eu vi o ladrão. (Gair, 1990, p.17)

Em hunzib:

(74) a. ozh.di-i kid $\quad y-a^{n} c^{\prime} A-r$ garoto.DAT garota.ABS II-ver-PAST

O garoto viu a garota. (Comrie \& van den Berg, 2006, p.130)

Ainda que se costume separar verbos de cognição e percepção, observa-se frequentemente uma polissemia entre os dois tipos de eventos, possivelmente indicando processos de extensão de significado.

Em georgiano, o verbo esmis 'ouvir' pode também significar 'entender', havendo o que parece ser uma extensão de um sentido perceptual, referente à audição, a um sentido cognitivo de 'entender': 
(75) a. [...] magram me

jer k'idev m-e-sm-i-s

misi

mas 1SG.DAT ainda

1BDAT-VPR-ouvir-ST-3ANOM dele.NOM

xma.

vOZ.NOM

[...] mas eu ainda ouço sua voz..$^{95}$

b. ar m-e-sm-i-s, mosvla-ze uari rat'om tkva não 1BDAT-VPR-entender-ST-3ANOM vindo-POSP recusar porque dizer Eu não entendo porque ele disse que se recusa a vir. ${ }^{96}$

Evans \& Wilkins (1998) também reportam extensão similar, do campo perceptual da audição ao campo cognitivo de 'saber, pensar', em línguas australianas.

Já em línguas como o inglês, é o verbo perceptual see 'ver' que é usado com o sentido de 'entender, compreender', extensão entre o domínio da visão ao cognitivo também investigada por Sweetser (1990) e identificada em línguas diversas.

Outra fonte de extensão, do domínio perceptual ao cognitivo, presente em georgiano é o verbo hgonia 'pensar, achar' com sentido próximo de 'ter a impressão de', 'parecer que'. Esse tipo de extensão é bastante comum nas línguas, usualmente com o experienciador no caso dativo, cf. no russo: mne kazhetsja; no inglês: it seems to me; no português: me parece que. A respeito do inglês, interessantemente, o verbo transitivo think 'pensar, achar' em inglês moderno foi assimilado ao padrão transitivo a partir do verbo experiencial thyncan 'it seems' do inglês antigo e médio (MALCHUKOV, 2005).

$\mathrm{Na}$ seção anterior, comentamos a respeito do verbo grdznob 'sentir' em georgiano, verbo este que, assim como em outras línguas, também é perceptual, sendo polissêmico com outros sentidos. Em Tariana, por exemplo, o verbo que vimos anteriormente -himeta 'sentir, entender' deriva do verbo perceptual -hima 'ouvir' (AIKHENVALD, 2000, p.169).

Já em georgiano, é polissêmico com sentidos como o tato (também em inglês e russo (cf. Rylina, 2013, p.12)). Compare em inglês "he felt the rock" 'ele sentiu a pedra' com o exemplo abaixo do georgiano:

\footnotetext{
${ }^{95}$ Fonte: www.Ids.org > 2013/04

${ }^{96}$ Fonte: https://translate.academic.ru/
} 
Ele sentiu o calor de sua pele com os dedos. ${ }^{97}$

Também é possível usar o verbo grdznob juntamente com o substantivo denotando o sentido como suni 'cheiro' e gemo 'gosto'.

Em português, o verbo 'sentir', assim como o verbo russo 'chuvstvovat", também podem ocorrer com substantivos denotando olfato e paladar, observe os exemplos abaixo e as traduções para o inglês e português. Os exemplos em russo foram retirados de Rylina (2013, p. 12):

- Paladar: Dzhon (nom.) chuvstvoval (3SG.PAST) vkus (acc.) perca (gen.)

João sentiu o gosto da pimenta.

John tasted the pepper.

- Olfato: Dzhon (nom.) chuvstvoval (3SG.PAST) zapax (acc.) supa (gen.)

João sentiu o cheiro da sopa.

John smelled the soup.

É interessante notar que em português somente há uma versão mais ativa com o sentido olfativo, 'Ele cheirou a sopa', denotando que o experienciador intencionalmente quis sentir o cheiro de alguma coisa. Já 'sentir o cheiro/gosto' traduz um evento muito mais experiencial em que talvez não houvesse controle ou intenção do experienciador.

Com o paladar, o que mais se aproximaria no português do sentido perceptual mais dirigido de 'cheirar' seria com o verbo 'experimentar'. Em georgiano, há um verbo de significado similar para o sentido de paladar, transitivo de morfologia de Classe I, sinj-av-s 'experimentar, taste (ingl.)'.

Já foi notado na literatura, aliás, que verbos perceptuais teriam de fato essa característica de apresentarem nas línguas um sentido mais ativo e outro mais inativo, por vezes, com diferenças de codificação entre eles ou de transitividade.

No sentido mais ativo, como no inglês look e listen 'olhar e escutar', o experienciador teria um papel mais agentivo, com uma atenção mais dirigida ao que é percebido, sendo um evento mais controlável. Já no sentido mais inativo, no inglês see e

\footnotetext{
${ }^{97}$ Fonte: https://www.wattpad.com/592416767
} 
hear 'ver e ouvir', o experienciador é tido como menos agentivo, podendo o evento ser mais acidental e incontrolável.

Malchukov (2005) discute a variação encontrada nas línguas no que concerne a codificação desses predicados, por exemplo, algumas línguas teriam padrões de transitividade distintos: verbos como 'ver' seriam mais transitivos (em inglês e português, 'I saw something' - 'eu vi alguma coisa'), enquanto verbos como 'olhar' seriam mais intransitivos (em inglês 'I looked at him' - 'eu olhei para ele'). ${ }^{98}$

Já em outras, como algumas línguas ergativas, verbos como 'olhar' é que seriam mais transitivos, recebendo uma marcação ergativa, enquanto verbos como 'ver' seriam marcados diferentemente, talvez a marcação ergativa indicando o maior controle do experienciador sobre o evento de 'olhar'.

Outras, como a língua lezgiana leste-caucasiana, marcariam 'olhar' e 'ver' intransitivamente, mas com padrões de marcação de caso diferentes, o experienciador de 'olhar' com o caso dativo e 'ver' com o caso absolutivo (cf. MALCHUKOV, 2005).

Em georgiano, embora a situação seja um pouco mais complicada, veremos que duas dessas tendências acima mencionadas podem ser observadas.

A maior complicação é que mesmo entre verbos perceptuais como 'ouvir' e 'ver', a marcação não é idêntica. Enquanto o experienciador do verbo esmis 'ouvir' é marcado com o caso dativo, o verbo $x e d-a v-s$ 'ver' é marcado tal como verbos diretos transitivos, isto é, com o experienciador no caso nominativo no presente e ergativo no aoristo.

No caso de esmis 'ouvir', a diferença entre uma percepção mais ativa e inativa pode ser mais claramente observada através da marcação de caso, enquanto esmis tem uma marcação dativa do experienciador, há outro verbo de mesma raiz na língua marcado com marcação direta usmen 'escutar' com sentido mais ativo. Compare os exemplos abaixo, em (77), com o verbo esmis 'ouvir':

\footnotetext{
${ }^{98} \mathrm{Em}$ algumas línguas bálticas, situação similar ocorre: em lituano, o estímulo de 'escutar' é marcado com o genitivo, enquanto o estímulo de 'ouvir' é marcado com o caso acusativo. Em latgaliano (língua báltica), tanto 'olhar' quanto 'escutar' têm o estímulo no caso genitivo (NAU, 2014, p. 240).
} 
(77) a. sul araperi m-e-sm-i-s

completamente nada 1BDAT-VPR-ouvir-ST-3ANOM

Eu não ouço nada. ${ }^{99}$

b. ise iqo pikr-eb-shi gartuli, rom chveni ar

tão 3SG.COP pensamento-PL-POSP levado.NOM que 1PL.NOM não

e-smo-da

VPR-ouvir-IMPF

Ele estava tão perdido em pensamentos que não nos ouvia.$^{100}$

Os exemplos a seguir ilustram o verbo usmen 'escutar':

(78) a. guldasmit mo-u-smin-a

atentamente PV-VPR-ouvir-3AERG.AOR

Ele a escutou atentamente. ${ }^{101}$

b. me v-u-smen musik'as, magram is ar

1SG.NOM 1ANOM-VPR-ouvir música.DAT mas isso não

mokmed-eb-s chem-ze

impactar-ST-3ANOM mim-POSP

Eu escuto música, mas isso não me impacta. ${ }^{102}$

A princípio, parece que o evento perceptual em (78) é mais dirigido e atentivo do que aqueles em (77), pressupondo que o experienciador intencionalmente dirigiu sua atenção e pôs-se a escutar. Em (77), o evento perceptual parece se desenvolver de forma mais espontânea ou despretensiosa, no sentido de que o sentido do experienciador é estimulado, não envolvendo necessariamente um experienciador que procure de forma dirigida escutar alguma coisa ou alguém, ainda que possa haver certo nível de atenção.

Em português, essa diferença parece ser mais saliente em relação a 'olhar' e 'ver' do que 'ouvir' e 'escutar'. É possível, por exemplo, 'olhar sem ver' e não o

\footnotetext{
${ }^{99}$ Fonte: https://translate.academic.ru/

${ }^{100}$ Fonte: https://translate.academic.ru/

${ }^{101}$ Fonte: https://translate.academic.ru/

102 Fonte: https://wol.jw.org/ka/wol/d/r20/lp-ge/102003126
} 
contrário, é possível 'dar uma olhada', mas não 'dar uma vista'. Olhar envolve dirigir a atenção e acontece com a intenção do experienciador de ver alguma coisa, mas não necessariamente pressupõe que esse objetivo seja alcançado, isto é, o objeto pode não ser visto (MALCHUKOV, 2005).

Em georgiano, esse tipo de diferença entre 'olhar' e 'ver' é mais difícil de captar, já que o verbo usado com sentido de 'ver' xed-av-s é um verbo direto de Classe I, ao contrário de esmis 'ouvir' que é um verbo indireto. Ainda assim, algumas observações importantes podem ser feitas.

Observe abaixo alguns exemplos com o verbo xed-av-s 'ver' (aor. naxa/da-inaxa). O exemplo (79a) está no presente, por isso o experienciador é marcado com o nominativo e o estímulo com o dativo; $(79 \mathrm{~b}$ e c) estão no aoristo, assim, o experienciador está no caso ergativo e o estímulo no caso nominativo:

(79) a. gamosavals ver v-xed-av solução.DAT não 1ANOM-ver-ST

Ele não vê solução. ${ }^{103}$

b. gushin v-nax-e ontem 1AERG-ver-1AERG.AOR

Eu o vi ontem. ${ }^{104}$

c. mogvianebit ramdenime k'ac-ma da-i-nax-a mais tarde alguns homem-ERG PV-VPR-ver-3AERG.AOR p'et're da u-txr-es [...] petre.NOM e VPR-dizer.3AERG.PL.AOR

Mais tarde, alguns homens viram Petre e disseram [...]. ${ }^{105}$

Em contraste, parece que um sentido mais próximo de uma percepção ativa de 'olhar', isto é, mais dirigida e intencional em relação ao estímulo, é tida através do uso de diferentes preverbos com a raiz xed (aor. -xeda). ${ }^{106}$

\footnotetext{
103 Fonte: https://translate.academic.ru/

${ }^{104}$ Fonte: https://translate.academic.ru/

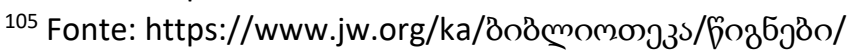


Observe os exemplos abaixo. Em (80b), atente para o contraste entre 'ver' e 'olhar':

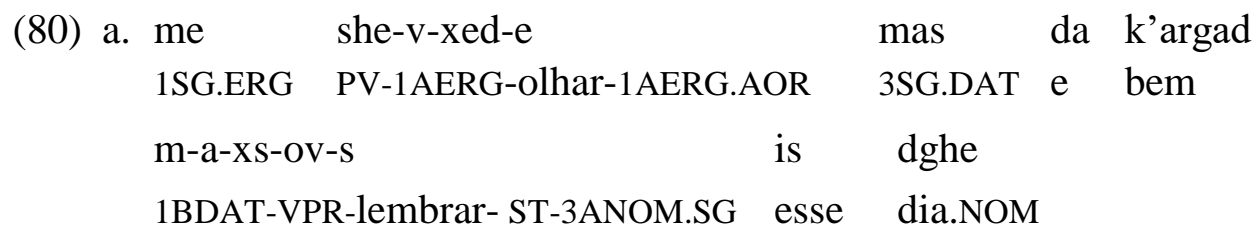

Eu olhei para ele e me lembrei bem desse dia. ${ }^{107}$

b. ga-v-i-xed-e,

PV-1AERG-VPR-olhar-1AERG.AOR mas nada

da-v-i-nax-e

PV-1AERG-VPR-ver-1AERG.AOR

Eu olhei (em uma direção), mas não vi nada. ${ }^{108}$

c. man jer c'ign-s da-xed-a, mere me

3SG.ERG antes livro-DAT PV-olhar-3AERG.AOR depois 1SG.DAT

shemo-m-xed-a da m-k'itx-a [...]

PV-1BDAT-olhar-3AERG.AOR e 1BDAT-dizer-3AERG.AOR

Primeiro ele olhou para o livro, depois me olhou e disse [...]. ${ }^{109}$

Todas as sentenças em (80) estão no aoristo. Como no presente do indicativo em georgiano o objeto direto tal como o objeto indireto são marcados com o caso dativo, uma forma de diagnóstico, para se ter certeza se o objeto em questão é direto ou indireto, é passar a sentença para o aoristo. Assim, se o objeto for direto, será marcado com o caso nominativo, se for indireto, continuará com o caso dativo.

Observe que nos exemplos em (80), enquanto o experienciador é marcado com o caso ergativo como esperado, o estímulo é marcado com o caso dativo, indicando que se trata de um objeto indireto. Esse dado é interessante e contrasta com os exemplos vistos

\footnotetext{
106 Sincronicamente, preverbos indicam aspecto em georgiano. Diacronicamente, no entanto, preverbos têm uma origem espacial, isto é, eram usados para indicar orientação ou direcionalidade, significado que atualmente na língua ainda é mantido com verbos de movimento (HEWITT, 1998).

107 Fonte: https://translate.academic.ru/

108 Fonte: https://translate.academic.ru/

${ }^{109}$ Fonte: https://translate.academic.ru/
} 
em (79), pois mostra que há marcações distintas entre um sentido mais próximo de 'ver' (marcando o estímulo como um objeto direto) e um sentido mais próximo de 'olhar' (marcando o estímulo como um objeto indireto).

Além dessa marcação distinta, há outras diferenças. Primeiro, há usos distintos de preverbos com o sentido de 'olhar': she- em (80a); ga- (80b); da- e shemo- em (80c). $\mathrm{O}$ que poderia, hipoteticamente, ser um remanescente de um sentido mais direcional desses preverbos, necessitando de uma busca mais aprofundada e sistemática nos diferentes usos de preverbos com a raiz xed.

Segundo, a raiz verbal xed se altera no aoristo com um sentido mais próximo de 'ver' (nax-a/da-i-nax-a), e permanece a mesma com um sentido mais próximo de 'olhar' (da-xed-a, she-xed-a, shemo-xed-a, ga-i-xed-a).

Os dados vistos acima permitem perceber que há duas marcações que se poderia chamar de não canônica em relação aos pares de verbos perceptuais em georgiano 'ouvir/escutar' e 'ver/olhar' e que refletiriam a distinção entre um evento perceptual mais ativo e inativo. A primeira se refere à marcação não canônica do experienciador, marcado com o caso dativo no caso de esmis 'ouvir', indicando possivelmente que o evento perceptual é inativo, isto é, o experienciador é menos volitivo e a experiência é menos controlável e intencional. O que estaria em contraste com a marcação direta equivalente usmen 'escutar' que indicaria que o experienciador tem mais controle sobre o evento perceptual, dirigindo sua atenção ao estímulo de forma intencional.

A segunda, incorporada na marcação de 'ver/olhar', enfatizaria uma marcação não canônica do estímulo. Enquanto $x e d-a v-s$ 'ver' apresentaria uma marcação mais transitiva, codificando o estímulo tal como um objeto direto, (ga-, da-, shemo-, she-) $x e d-a v-s$ 'olhar' teria uma marcação mais intransitiva, codificando o estímulo tal como um objeto indireto.

Como menciona Malchukov (2005), da mesma forma que um evento perceptual inativo envolveria um experienciador menos agentivo, também envolveria um objeto mais 'alcançado', isto é, 'ver' pressupõe que o objeto foi de fato visto, nesse ponto, o estímulo estaria muito mais próximo de um paciente prototípico na escala de transitividade (no sentido de Hopper \& Thompson (1980)) do que o objeto de 'olhar', sendo menos prototípico, já que pode não ser realmente alcançado ou 'visto'. Daí, viria o favorecimento de uma marcação não canônica do estímulo de 'olhar' comparadamente a 'ver', este mais transitivo em termos de prototipicidade do estímulo. 
Dessa forma, os verbos perceptuais em georgiano, em particular em relação aos sentidos da audição e visão, apresentariam duas das tendências apontadas pela literatura (cf. Malchukov (2005)) como ocorrendo translinguisticamente e mencionadas anteriormente: a marcação distintiva do experienciador no caso de uma percepção inativa (menos controlável e intencional) e a marcação distintiva do estímulo no caso de uma percepção mais ativa, mas com um objeto menos alcançável e menos afetado e, assim, menos prototípico.

\subsubsection{Verbos de modalidade}

Os verbos de modalidade incluem eventos de obrigação, dever e falta. Autores como Onishi (2001) também incluem nesse grupo verbos de querer, necessidade, possibilidade/capacidade, tentativa, sucesso, insucesso e verbos com sentido evidencial como 'parecer'.

Assim, embora tenhamos colocado verbos como unda, nebavs 'querer' $\mathrm{e}$ ch'irdeba 'precisar' na lista de verbos emocionais, pelo seu sentido, eles também poderiam figurar como verbos de modalidade. De fato, em muitas línguas, o verbo 'querer' é ambíguo entre 'querer' e verbos emocionais como 'gostar/amar'.

Em espanhol, por exemplo, te quiero equivale a 'te amo'. Na maior parte das línguas leste-caucasianas como tabasaran, tsez, lezguiano, tsakhur, icari dargi, chamalal, godoberi, akusha dargi, avar, akhvakh, archi, agul, andi e bagwalal, essa mesma ambiguidade também ocorre (cf. COMRIE \& VAN DEN BERG, 2006; GANENKOV, 2006). Em lezguiano, por exemplo, o verbo $k$ 'an- pode significar 'amar, querer, precisar', compare os exemplos:

(81) a. za-z wun k'an-zawa

1SG-DAT 2SG.ABS amar-IMPF

Eu amo você. (HASPELMATH, 1993, p.137) 
b. qadim.a-z wichi-n rush Allahq'uli.di-z gu-z k'an-zawa-lda Qadim-DAT sua-GEN filha Allahquli-DAT dar-INF querer-IMPF-EVID Dizem que Qadim quer dar sua filha a Allahquli. (HASPELMATH, 1993, p.148).

Em wolof, uma língua nígero-congolesa, o verbo bëgg 'querer' também pode significar 'amar':

$\begin{array}{llll}\text { a. dama } & \text { bëgg } & \text { jigéén jii } \\ \text { 1SG } & \text { querer } & \text { mulher } & \text { DEM }\end{array}$

Eu amo essa mulher. (BECHER (2003) apud FEDRIANI, 2014, p.28)

Esses dados mostram que verbos modais como 'querer' podem apresentar uma miríade de significados que vão desde os mais 'modais' aos mais 'experienciais', ocorrendo muitas vezes extensões de um sentido ao outro.

Por exemplo, como nota Ganenkov (2006), em muitas línguas (como as lestecaucasianas, georgiano, línguas indo-europeias tais como búlgaro, francês, português, etc.), 'ter conhecimento' se confunde com 'ter a habilidade, ser capaz de, poder', parecendo ser um caminho metafórico natural em que o fato de alguém ter $o$ conhecimento de algo faz com que esse alguém seja capaz de executar aquela atividade.

Dessa forma, o verbo cognitivo 'saber' é frequentemente usado com sentido de 'ser capaz de, poder', observe o exemplo de karata (língua leste-caucasiana):

$$
\begin{array}{llll}
\text { a. } & \mathrm{d}_{\mathrm{j}} \mathrm{a} & \text { bii- } \mathrm{d}_{\mathrm{j}} \mathrm{a} & \mathrm{k}_{\mathrm{o}} \text { alch'aa-La } \\
\text { 1SG.DAT } & \text { saber-PRES } & \text { nadar-INF } \\
\multicolumn{3}{c}{\text { Eu sei nadar. (GANENKOV, 2006, p.185) }}
\end{array}
$$

Também em português, como a tradução indica, o verbo 'saber' também é usado com o sentido de 'ser capaz de, poder'. Observe os exemplos em georgiano abaixo e as respectivas traduções para o português: 

a. curva ar v-ici
nadar não 1ANOM-saber
Eu não sei nadar. ${ }^{110}$
b. bevri ena ici-s
muita língua saber-3ANOM.SG
Ele sabe muitas línguas. ${ }^{111}$

Nesses casos, 'saber' significa poder nadar ou falar determinada língua, ter, de fato, a capacidade. Interessantemente, em línguas como o inglês, sentenças como 'eu sei nadar' podem ser traduzidas com expressões como: 'I can swim' ou mesmo 'I know how to swim', este último já oscilando metaforicamente entre 'ter conhecimento' e 'ter a habilidade através do conhecimento'.

Outra fonte metafórica, e que acreditamos favorecer uma marcação não canônica, é o uso de verbos modais de forma impessoal. Em russo, por exemplo, diversos verbos modais marcam o experienciador com o caso dativo (cf. Offord (2005)), marcação similar ao uso de verbos indiretos experienciais em georgiano:

- mne mozhno 'é possível para mim, eu posso'; mne nado 'é necessário para mim, eu devo'; mne nel'zja ‘é impossível para mim, eu não posso, eu não devo’;

- nedostavat' 'ser insuficiente'; prixodit'sja 'ter que'; cledovat' 'dever'; udavat'sja 'ter sucesso'.

Observe que os verbos acima são impessoais estruturalmente no sentido de que o sujeito é oblíquo e não concorda com o verbo. A diferença entre o primeiro grupo e o segundo é que este é flexionado na terceira pessoa, enquanto aquele é inflexionável.

Conceitualmente, verbos modais assemelham-se a verbos experienciais na medida em que o participante dativo torna-se, metaforicamente, o alvo da experiência ou do evento irrealis. Em russo, muitos outros verbos experienciais também vão ter essa estrutura como nravit'sja 'gostar, ser agradável a' e expressões com o experienciador no dativo mais a forma neutra de adjetivos como mne ploxo 'eu não me sinto bem' (lit. ‘é/está mal para mim’)

\footnotetext{
${ }^{110} \mathrm{https}: / /$ translate.academic.ru/en/ka/

${ }^{111} \mathrm{https}: / /$ translate.academic.ru/en/ka/
} 
Em georgiano, o verbo unda apresenta tanto o sentido de 'querer', sendo flexionado de acordo com a pessoa, quanto o sentido de 'dever, ter que', nesse caso é inflexionável. Note que no segundo caso a marcação de caso e concordância segue o padrão do verbo principal.
a. shen
g-i-nd-a
es c'igni?
2SG.DAT 2BDAT-VPR-querer-3ANOM esse livro.NOM
Você quer esse livro?

b. tkven es st'at'ia unda da-c'er-o-t

2PL.ERG esse artigo.NOM dever PV-escrever-2AERG.OPT-PL

Vocês deveriam escrever esse artigo. (CAMPBELL, s/d, p.233)

O verbo sheudzlia 'poder, ser capaz de' também pode ser usado de forma inflexionável, significando 'ser possível, poder':
a. sheidzleba shemo-v-id-e
poder
PV-1ANOM-entrar-1ANOM.OPT
Posso entrar? (ARONSON, 1990, p. 144)

Nesses casos, as formas impessoais e inflexionáveis unda e sheidzleba assemelham-se a nado e mozhno do russo vistas acima, a diferença sendo que a concordância e marcação de caso observadas seguem o padrão do verbo principal em georgiano.

De fato, estruturas modais são variáveis translinguisticamente. Na língua sérvia, por exemplo, a concordância pode ocorrer no modal ou no verbo principal a depender do modal, já em línguas germânicas, a corcordância é sempre no modal (cf. LEISS \& ABRAHAM, 2014). Além do mais, modalidade nas línguas pode aparecer através de verbos auxiliares ou de afixos. 
Em línguas dravídicas, como malaiala e tamil, há modais sufixais que ocorrem no infinitivo, o sujeito sendo marcado com o caso dativo, observe os exemplos provenientes de malaiala:

(87) a. nina-kkA naaLe pook-aam 2PL.DAT amanhã ir-poder Vocês podem ir amanhã. (NIZAR, 2010, p. 12)

b. eni-kkA naaLe sinima kaaN-aNam 1SG.DAT amanhã filme ver-querer Eu quero ver um filme amanhã. (NIZAR, 2010, p.12)

Construções modais com cópulas são também comuns. Em irlandês, por exemplo, construções copulares como b'éigean do 'é necessário para' são usados com o sentido de 'ter que, dever', o sujeito sendo marcado com a preposição do mais o dativo:

(88) a. b' éigean dom

COP necessário para.mim

Eu tenho que, eu devo. (MCQUILLAN, 2009, p. 74)

Essas construções copulares com dativos se assemelham às construções modais com advérbios do russo citadas há pouco. No russo, no entanto, a cópula no tempo presente não é codificada, aparecendo somente no tempo passado, nesse caso, mantémse na forma da terceira pessoa neutra do singular, compare:

(89) a. mozhno mne idti?

possível 1SG.DAT ir.INF

Eu posso ir? (HANSEN, 2014, p. 104) 

b. mozhno mne bylo idti? possível 1SG.DAT COP.PAST.SG.NEUT ir.INF Eu poderia ir? (HANSEN, 2014, p. 104)

Modalidade nas línguas é um assunto complexo e com vasta literatura e, por isso, não poderá ser tratado de forma mais abrangente aqui. No entanto, alguns comentários devem ser feitos a respeito da ligação conceitual entre modalidade e eventos experienciais evidenciada pela marcação com o caso dativo.

Em primeiro lugar, eventos modais, seguindo Hopper \& Thompson (1980), são eventos de baixa transitividade por serem irrealis, distanciando-se de eventos factuais e realis de maior transitividade e favorecendo uma marcação diferencial.

Em segundo, assim como eventos experienciais, eventos modais parecem relacionar-se a construções impessoais nas línguas como os exemplos acima demonstram, facilitando uma marcação de sujeito de forma oblíqua, nesses casos, como o recipiente ou alvo da possibilidade, da obrigação, da necessidade, etc. Além do mais, por serem eventos irrealis, i.e., normalmente apresentam projeções no futuro e possibilidades não concretizadas ou não confirmadas, seus participantes acabam por ter um menor grau de volicionalidade sobre o evento, não sendo típicos agentes.

Outro ponto importante que deve ser notado é que nos casos do russo e do irlandês vistos acima, a conexão entre uma possível extensão da construção dativa modal, i.e., com um experienciador dativo como participante mais proeminente, a partir de uma construção impessoal, se faz mais clara, já que os indícios tais como a presença da cópula e ausência de concordância, estando a cópula na terceira pessoa do singular, favorecem o estabelecimento dessa conexão.

Em georgiano, a situação é um pouco diferente, na construção dativa com o experienciador dativo como nas formas minda 'eu quero', a concordância é feita com o nominal dativo e o verbo se comporta como uma forma verbal plena e flexionável. Assim como com outros verbos indiretos na língua, a raiz (que sofreu alterações diacronicamente) é antiga e atestada desde os registros mais antigos do georgiano já ocorrendo com um nominal dativo como experienciador.

A construção impessoal do georgiano vista acima com a terceira pessoa do singular unda é, no entanto, comparadamente recente, possivelmente sendo derivada a partir do verbo flexionável (SHARASHENIDZE, 2014). 
Segundo a hipótese de Sharashenidze (2014), a forma inflexionável unda surgiu a partir de construções subordinadas com o verbo flexionável mais um verbo flexionável no subjuntivo: minda, rom gavak'eto 'eu quero fazer, lit. eu quero que eu faça'. Com o passar do tempo, a forma impessoal unda teria começado a substituir a forma flexionada: minda gavak'eto $>$ unda gavak'eto, adquirindo mais tarde novos significados modais.

Se assim for realmente o caso, explicaria o porquê de a construção impessoal modal em georgiano ter o experienciador marcado de acordo com a regência do verbo principal e não mais com o dativo, justificando as diferentes estruturas observadas entre casos como russo e irlandês e o georgiano, e que também evidenciam caminhos conceituais distintos, pelo menos no que se pode verificar da história registrada do georgiano.

Outra relação construcional interessante e já apontada na literatura, é a conexão frequente nas línguas entre construções modais e de posse/existencial envolvendo, muitas vezes, a cópula e também o uso do dativo, à semelhança da construção em latim mihi est 'para mim é'.

De acordo com Holvoet (2009), essa construção do latim serviu de base para diversas construções modais nas línguas bálticas e também em línguas eslavas como o russo (cf. JUNG, 2010, para hipótese semelhante a respeito da construção infinitiva com dativo no russo). Em línguas românicas como o português, relação próxima também se verifica, não através do dativo, mas da forma verbal utilizada 'ter', compare a construção possessiva 'eu tenho um livro' com a construção de modo designando dever, obrigação: 'eu tenho que ler o livro'.

Um deles é o modo debitivo em letão, que indica obrigação ou dever de fazer algo e tem seu participante marcado com o caso dativo:

\begin{tabular}{|c|c|c|c|}
\hline Iums & em & balta & papīra \\
\hline
\end{tabular}

Nós temos que pegar uma folha branca de papel. (LOKMANE \& KALNACHA, 2014, p.183) 
Segundo Holvoet (2009), o modo debitivo teria sido derivado de uma sentença relativa encaixada em uma construção existencial: proto-letão *man (1SG.DAT) nav (ser.PRES3.NEG) ja (REL.GEN.SG.N) est (comer.INF) 'eu não tenho o que comer' > letão moderno man (1SG.DAT) nav (ser.PRES3.NEG) jaed (DEB.comer) 'eu não preciso comer'; man jaed 'eu preciso comer'.

Como será objeto da seção seguinte, no georgiano, o verbo de posse akvs/hqavs também tem o possuidor marcado com o caso dativo tal como o verbo unda e demais verbos indiretos experienciais.

Esses dados são interessantes de um ponto de vista da família de construções envolvendo a construção dativa em uma variedade de línguas, mostrando que há uma relação de significado relevante translinguisticamente por detrás da marcação similar entre verbos experienciais, de modalidade e de posse.

Falaremos mais sobre casos envolvendo modo e evidencialidade quando discutirmos, respectivamente, os chamados verbos desiderativos e as Séries III (evidencial) em georgiano.

\subsubsection{Verbos de posse}

Ainda que verbos de posse não se alinhem estritamente a uma definição de verbos experienciais (no sentido de experienciar uma emoção ou sensação física), estes têm uma relação bastante próxima com aqueles tanto no que concerne a marcação dativa através das línguas, quanto a serem também eventos abstratos e potencialmente ‘experienciais' (cf. seção 5.3.4.1 a seguir).

Argumenta-se que essa polissemia em marcação se justifica de um ponto de vista conceitual, havendo o que acreditamos ser similaridades na forma como esses eventos são conceitualizados. E são essas similaridades que parecem ser refletidas na codificação próxima entre eventos experienciais e de posse (e também modais como vimos na seção anterior).

De fato, translinguisticamente o que se observa é uma tendência de a construção dativa se estender tanto a verbos experienciais quanto a verbos de posse. 
A começar pelo próprio exemplo do georgiano em que os verbos designando posse akvs (para objetos possuídos inanimados) e hqavs (para objetos possuídos animados) têm o possuidor marcado com o caso dativo.

Em russo moderno, como já mencionado, o dativo marca frequentemente o experienciador. A construção de posse, no entanto, é marcada por uma construção proposicional com o caso genitivo, observe:

$\begin{array}{llll}\text { u } & \text { menja } & \text { byla } & \text { kniga } \\ \text { em.PREP } & \text { mim.GEN } & \text { ser.PASS.FEM.SG livro.NOM.FEM.SG } \\ \text { Eu tenho um livro. (JUNG, 2010, p.379) }\end{array}$

Historicamente, o dativo ocupava o lugar do genitivo, este substituindo o dativo gradualmente durante o período moderno da língua (JUNG, 2010). Resquícios do dativo no russo, relacionados à construção de posse, ainda podem ser observados em construções indicando idade e que em muitas línguas se observa a utilização de verbos de posse: em russo $e m u_{\mathrm{DAT}}$ god $_{\mathrm{NOM}}$ 'ele tem um ano (em port.)'.

Como mencionado na seção anterior, o latim tem a conhecida construção de posse com o dativo e a cópula mihi est, construção encontrada em diferentes ramos do indo-europeu, por exemplo, em hindi, língua indo-ariana:

$$
\begin{array}{lll}
\text { John-ko } & \text { sirdard } & \text { hai } \\
\text { John-DAT } & \text { dor.de.cabeça } & \text { ser.PRES } \\
\text { John tem dor de cabeça. (JUNG, 2010, p.379) }
\end{array}
$$

Segundo o estudo de Barðdal et al (2012), a construção dativa com o significado de 'ter, possuir' é atestada, além do latim, em grego, russo antigo e lituano antigo (cf. p. 8), evidenciando para sua antiguidade na família indo-europeia.

Não é, no entanto, somente em línguas indo-europeias que a construção de posse com dativo é encontrada. Além do caso do próprio georgiano, em malaiala, uma língua dravídica, também se observa marcação dativa de posse, alienável e inalienável, similar a verbos experienciais: 


$\begin{array}{llll}\text { eni-kkA } & \text { valiya } & \text { viiTA } & \text { uNTA } \\ \text { 1SG-DAT } & \text { grande } & \text { casa } & \text { ser.PRES } \\ \text { Eu tenho uma casa grande. } & (\text { NIZAR, 2010, p.11) }\end{array}$

Há de se notar que, além de verbos designando posse em georgiano, também incluímos no grupo de verbos de posse os verbos u-p'qria 'estar segurando' e hkvia 'ser chamado', sendo particularmente interessante a marcação dativa desses verbos.

Em relação ao primeiro, nota-se que existe em algumas línguas uma extensão metafórica do verbo 'segurar' a um sentido de 'ter/possuir'. Em espanhol, por exemplo, o verbo tener passou por uma transição de um verbo significando 'segurar' para um verbo com sentido de 'ter'. Em lituano, situação similar ocorreu, o verbo tureti 'ter' tinha originalmente o significado de 'segurar', sentido preservado ainda em letão (HOLVOET, 2009).

Nesses casos, parece ocorrer uma extensão de um sentido mais concreto e experiencial, 'segurar com as mãos alguma coisa', para um sentido mais abstrato de 'ter posse de alguma coisa' (cf. seção 5.3.4.1), tornando próxima a relação conceitual entre esses verbos e possivelmente justificando a marcação dativa de verbos como up'qria 'segurar' do georgiano.

Em relação ao verbo hkvia 'ser chamado', é interessante observar que essa mesma marcação dativa do participante que é chamado ou nomeado também ocorre em outras línguas. Barðdal et al (2012) lista esse predicado no grupo de verbos de posse que teriam marcação dativa tanto em latim (nomen esse - mihi est nomen 'eu me chamo, sou chamado de') quanto em grego antigo (onoma einai). Talvez, como parece mais evidente em latim, a marcação dativa desse tipo de verbo esteja ligada a um ato de ‘ter/possuir um nome' ou mesmo a um ato de atribuir um nome a alguém, neste caso, o nomeado sendo o alvo do ato de nomear.

Outro fenômeno que associa o dativo à posse é o conhecido na literatura linguística como posse externa em que o possuidor é marcado com o caso dativo e o participante possuído é usualmente marcado como objeto direto ou preposicionado do verbo. Essa construção é usualmente contrastada com a posse interna que apenas 
marcaria posse, enquanto a característica mais marcante da posse externa seria a ênfase na maior afetação do participante dativo (cf. análise de Maldonado (2002) na seção 6.3).

A posse externa é bastante comum em georgiano, assim como em línguas europeias como as românicas, eslavas e línguas germânicas como alemão e holandês (cf. HASPELMATH, 1999).

Compare os exemplos do georgiano a seguir com os exemplos do português, espanhol, esloveno e tcheco abaixo (possuidor dativo em itálico):

(94) Me roubaram o carro.

(95) Adrián le arruinó la fiesta a Valéria. (lit.: Adrian arruinou a festa de Valéria) (Maldonado, 2002, p.2)

(96) Zdravnik jim je pregledal zhelodec doutor 3PL.DAT AUX examinado estômago O doutor examinou o estômago deles. (HASPELMATH, 1999, p.110)

(97) Ludmila mu dala pusinku na čelo Ludmila.NOM 3SG.DAT dar beijo.ACC em testa.ACC Ludmila deu um beijo em sua testa (JANDA, 1993, p.48).

Em georgiano:

(98) a. muceli m-t'k'iv-a

estômago.NOM 1BDAT-doer-3ANOM

Meu estômago dói. (Eu sinto dor no estômago)

b. mshobl-eb-i adre da-e-xoc-a mas

pais-PL-NOM cedo PV-VPR-morrer-3ANOM 3SG.DAT

Seus pais morreram cedo. (TUITE, 1998, p.128) 
c. ga-u-natda-t tval-eb-i moxuc-eb-s

PV-VPR-brilhar-PL olho-PL-NOM velho-PL-DAT

Os olhos das pessoas velhas se iluminaram. (TUITE, 1998, p.113)

d. chvil-i me m-e-k'bin-eb-a

criança-NOM 1SG.DAT 1BDAT-VPR-morder-ST-3ANOM

Minha criança é mordida (e.g. por insetos). (AMIRIDZE, 2006, p.177)

e. shen xach'ap'ur-i g-e-c'v-eb-a

2SG.DAT xatchapuri-NOM 2BDAT-VPR-queimar-ST-3ANOM

Seu xatchapuri está queimando. (AMIRIDZE, 2006, p.171)

f. me k'omp'iut'er-i isev gada-m-e-t'virt-a

1SG.DAT computador-NOM novamente PV-1BDAT-VPR-reiniciar-3ANOM

Meu computador reiniciou novamente. (AMIRIDZE, 2006, p.171)

Note que os exemplos do georgiano (assim como o exemplo em português e outras línguas) não codificam apenas um evento de posse, mas conceitualizam esse evento como algo que afeta o possuidor, assim, o participante dativo é, além de possuidor, também um tipo de experienciador na medida em que é afetado ativamente por aquele evento, aproximando-se do papel desempenhado por maleficiários e beneficiários.

É interessante trazer, neste momento, a análise de Langacker (1998; 2008; 2009) acerca das construções possessivas (e sua semelhança com construções existenciais e locativas). Sua análise será retomada em outros momentos desta tese e, por isso, é pertinente introduzi-la nesta seção.

\subsubsection{Pontos de referência e posse na GC}

Assim como vimos no capítulo 2, na GC, noções gramaticais como substantivo, verbo, sujeito e objeto são definidas conceitualmente por meio de um protótipo (baseado em arquétipos conceituais aterrados experiencialmente) e de uma 
caracterização esquemática, válida para todas as instâncias, e que evoca uma capacidade cognitiva que é imanente no arquétipo, sendo posteriormente estendida a outros casos.

No caso da caracterização conceitual de possessivos (tais como possessivos nominais (no inglês X's Y) e oracionais (no inglês X has a Y)), Langacker identifica como prototípicas as noções de posse, parentesco e relações de parte/todo, sendo a primeira a mais central. Essas noções são arquetípicas no sentido de serem fundamentais em nossa experiência diária no mundo e cognitivamente básicas.

Como caracterização esquemática, Langacker identifica nossa capacidade cognitiva de ponto de referência que consistiria na capacidade que temos de evocar uma entidade como meio para estabelecer contato mental com outra, observe:
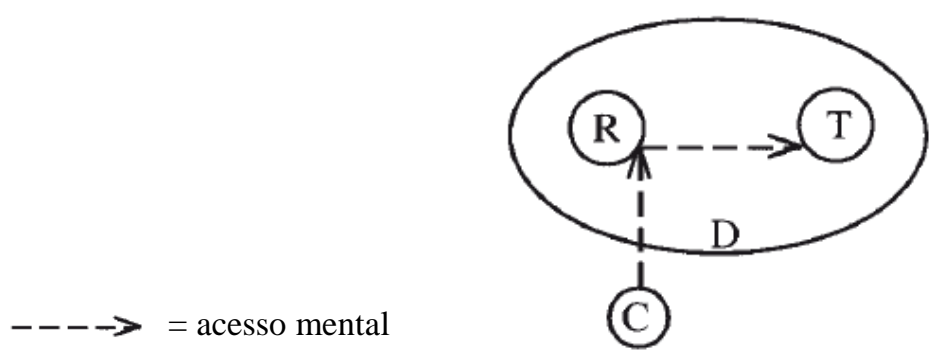

Figura 2: Caracterização esquemática de possessivo (LANGACKER, 2009, p. 84)

No esquema, há um conceitualizador (C) que dirige sua atenção à entidade servindo como ponto de referência (R), ao atentar para essa entidade, uma série de outras entidades associadas são também evocadas (fazendo parte coletivamente de seu domínio (D) ${ }^{112}$ ), dessas, a entidade selecionada constitui o alvo (T). Dessa forma, é por meio dessa capacidade cognitiva que somos capazes de conceitualizar relações de posse, parte/todo e de parentesco, sendo inerente em sua concepção.

Por ser uma capacidade cognitiva, pode ser explorada linguisticamente em uma miríade de diferentes fenômenos, cada um impondo seu próprio construal no conteúdo assim organizado.

Essa capacidade cognitiva se manifesta de forma imanente nas noções arquétipas de possessivos, por exemplo, relações de parentesco como 'pai', 'irmã', 'tio' só se

\footnotetext{
${ }^{112}$ Domínio é a região conceitual (como um conjunto de entidades) à qual um ponto de referência
} possibilita acesso direto (por exemplo, o conjunto de alvos potenciais). 
constituem como tal via referência a outras entidades, 'o pai da Maria', é somente através da referência da Maria que a entidade designada pode ser qualificada como 'pai'. Da mesma forma, em relações de parte e todo, a parte só pode ser apreendida através de sua relação com o todo.

No protótipo de posse, o possuidor (que funciona como ponto de referência) tem de alguma forma controle sobre o possuído (o alvo), seja física, social ou experiencialmente. Esse controle sobre o possuído acarreta um privilégio de acesso a ele, por exemplo, numa expressão como 'minha caneta', 'caneta' é um objeto associado a mim e sobre o qual eu tenho controle, posso manipular, etc. Nesse ponto, pessoas têm uma saliência cognitiva maior do que objetos, já que é mais fácil identificar objeto(s) em relação às pessoas do que o contrário. Por isso, há uma assimetria no sentido de que possuidores são pontos de referência naturais, suas posses sendo os alvos (LANGACKER, 2009).

$\longrightarrow=$ acesso/controle de

$\mathrm{R}$ por $\mathrm{T}$ (social, experiencial, físico)

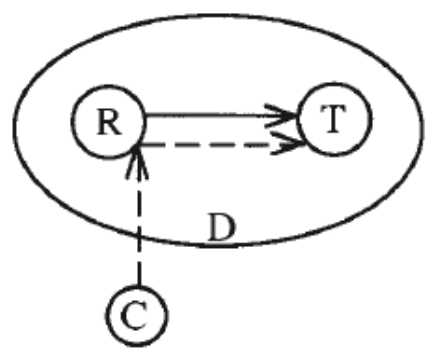

Figura 3: Caracterização do protótipo de possessivo (LANGACKER, 2009, p. 84)

Observe pela figura que o conceitualizador acessa mentalmente o possuidor (R) e através dele faz contato mental com o possuído (T), apreendendo o controle de $\mathrm{R}$ sobre T. Ainda que prototípico, a relação contruída em que o possuidor tem controle sobre o possuído se torna mais tênue em instâncias mais periféricas, tais como em expressões como 'sua idade', 'o tamanho do cachorro', 'suas críticas' etc. Nesses casos, como nota o autor, é difícil discernir algum tipo de controle do possuidor em relação ao possuído. Dessa forma, Langacker argumenta que em casos como esses apenas a caracterização esquemática (Figura 2) é discernível, i.e., nossa capacidade de evocar um ponto de referência para acessar mentalmente um alvo localizado dentro do domínio de $\mathrm{R}$. 
Observe que essa caracterização esquemática estaria presente tanto em possessivos nominais quanto em possessivos oracionais, a diferença sendo uma questão de perfil. Observe as figuras, em que uma linha sólida foi adicionada ao lado de $\mathrm{T}$ para representar a relação de T estando localizado em D:
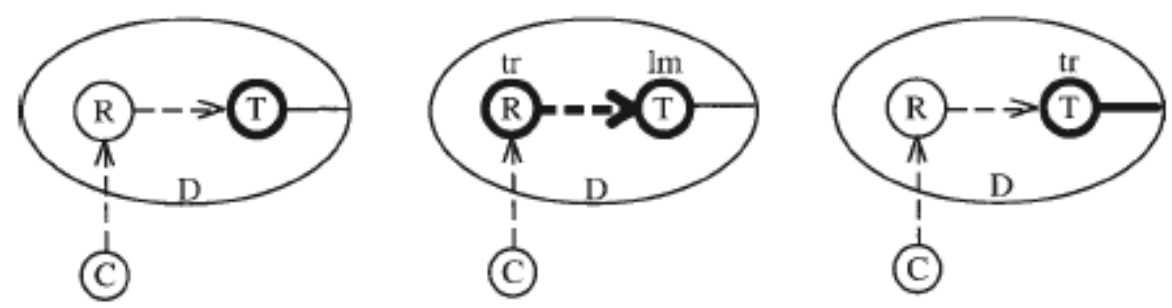

Figura 4: possessivo nominal, possessivos oracionais com o verbo 'ter' e possessivos locativos com o verbo 'ser', respectivamente (LANGACKER, 2009, p.89).

Em possessivos nominais (como Jerry's house 'a casa de Jerry'), é perfilada uma coisa (em contraste com um processo), essa coisa sendo a entidade possuída que é acessada via o ponto de referência (o possuidor). Assim, possessivos nominais servem para identificar o referente nominal e possibilitar uma base para selecionar uma instância de diversas instâncias de um tipo, ou seja, é a casa de Jerry, e não qualquer outra casa.

Já possessivos oracionais perfilam a relação possessiva em si. Os dois tipos de possessivos clausais diferem em relação a qual faceta dessa relação é selecionada como perfil: uma em que $\mathrm{R}$ controla $\mathrm{T}$ (minimamente, no sentido passivo de possibilitar acesso mental a $\mathrm{T}$ ); e outra em que $\mathrm{T}$ está localizado na região controlada por $\mathrm{R}$ (ativamente ou passivamente).

O primeiro tipo caracteriza sentenças como 'ele tem uma casa' que instancia, nesse caso, a construção transitiva (ainda que o evento de 'ter' seja baixo em transitividade).

Como foi notado acima, diacronicamente, é conhecida a origem de verbos como 'ter' a partir de expressões designando ocorrências físicas nas quais o sujeito manipula ou interage com um objeto (cf. em espanhol, tener < latim tenere 'segurar, manter, agarrar'), resultando em construções envolvendo um agente, o possuidor, e um paciente, o possuído. 
Segundo Langacker (2009), o caminho evolutivo, de um evento descrevendo controle físico a um evento de posse prototípico, envolveria uma atenuação no grau de controle do agente, em relação a diversos parâmetros.

Primeiro, um predicado possessivo não pressupõe uma ação em relação àquele objeto, apenas o potencial de interação com o objeto possuído. Segundo, o controle por parte do possuidor, quando exercido, não se limita à interação física, estendendo-se também a situações abstratas (como em sentenças 'meu irmão tem um ótimo emprego'), sendo que em certos usos, o controle ativo do possuidor é praticamente nulo (como em 'Maria tem olhos azuis' ou 'A casa tem quatro quartos'), em que funciona apenas como um ponto de referência para designar onde o objeto (ou característica) pode ser achado.

Esses estágios básicos do caminho evolutivo, delineados pelo autor, estão ilustrados abaixo:

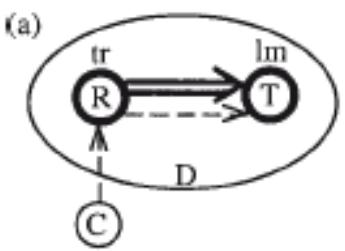

Controle agentivo:

- evento físico específico

- emprego de força

- verbo perfectivo

- fonte possessiva

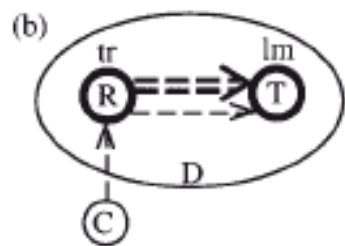

Controle ativo: - privilégio de acesso - potencial de interação - verbo imperfectivo - protótipo de possessivo (c)

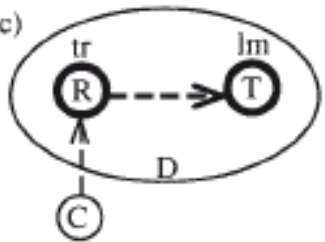

Controle passivo:

- ponto de referência passivo

- acesso mental por $\mathrm{C}$

- verbo impefectivo

- esquema de posse

Figura 5: Caminho evolutivo: predicado fonte (a), protótipo de possessivo (b) e caracterização esquemática do possessivo (c) (LANGACKER, 2009).

Observe que a caracterização esquemática permanece a mesma em todos os estágios, em que $\mathrm{C}$ traça um caminho mental via $\mathrm{R}$ para $\mathrm{T}$. Conforme os traços de controle ativo são atenuados, o que resta por último é uma predicação locativa na medida em que $\mathrm{R}$ serve apenas como um ponto de referência evocado por $\mathrm{C}$ para localizar T. Como o predicado originalmente era baseado na noção de controle, sua configuração básica permanece, i.e., $\mathrm{R}$ funciona como trajetor e $\mathrm{T}$ como marco.

Como já foi notado, no entanto, essa não é a única estratégia que as línguas utilizam para codificar eventos de posse, uma forma bastante comum é utilizar um 
verbo como 'ser' ou 'existir' em conjunto com um sintagma locativo (correspondendo ao terceiro esquema na Figura 4 acima), exemplos desse tipo de construção foram dados no início desta seção.

De fato, as duas construções, com o verbo 'ter' e locativas com o verbo 'ser/estar', têm origens diacrônicas distintas, a primeira a partir de verbos de controle físico e a segunda a partir de fontes locativas/existenciais. O que explicaria então o significado comum de posse?

Para explicar a fonte desse significado comum, Langacker (2009) passa, primeiro, a caracterizar as noções locativa e existencial. Tanto a noção locativa quanto existencial são relativas a algum domínio (domain), normalmente espacial. A relação das duas é próxima, já que é possível dizer que uma predicação existencial é uma especificação locativa maximamente esquemática e generalizada:

(a)

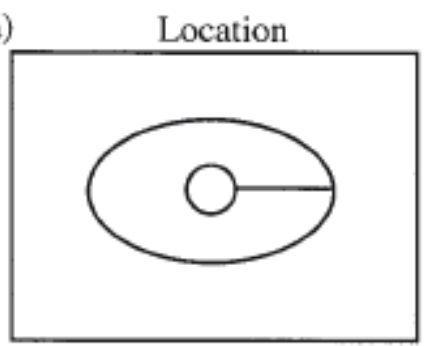

(b)

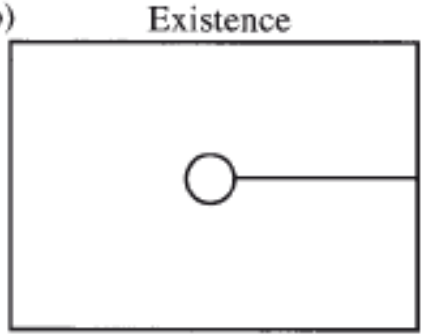

$\square=$ domínio de existência $\quad \bigcirc=$ região delimitada
$\bigcirc$ = entidade sendo localizada $\quad-$ = relação locativa

Figura 6: Distinção entre noções locativa e existencial (LANGACKER, 2009, p.99)

Em sua caracterização, uma expressão locativa identifica uma região delimitada, onde uma determinada entidade pode ser achada, através de um objeto referente. Esse objeto referente funciona como um marco espacial, em relação ao qual é especificado um domínio de busca.

$\mathrm{Na}$ figura abaixo, estão ilustradas as preposições inglesas above 'acima', beside 'ao lado', in 'em', e a representação esquemática locativa em (d). Observe que em todos os casos, o alvo (T) ocupa um domínio de busca (D) definido em relação ao objeto de referência (R). No caso de in, o domínio e objeto de referência são coextensivos. Dessa 
forma, uma relação perfilada por uma posposição ou preposição é a de que o alvo (T) ocupa um local acessível via o ponto de referência $(\mathrm{R})$, sendo o primeiro o trajetor e o segundo o marco.
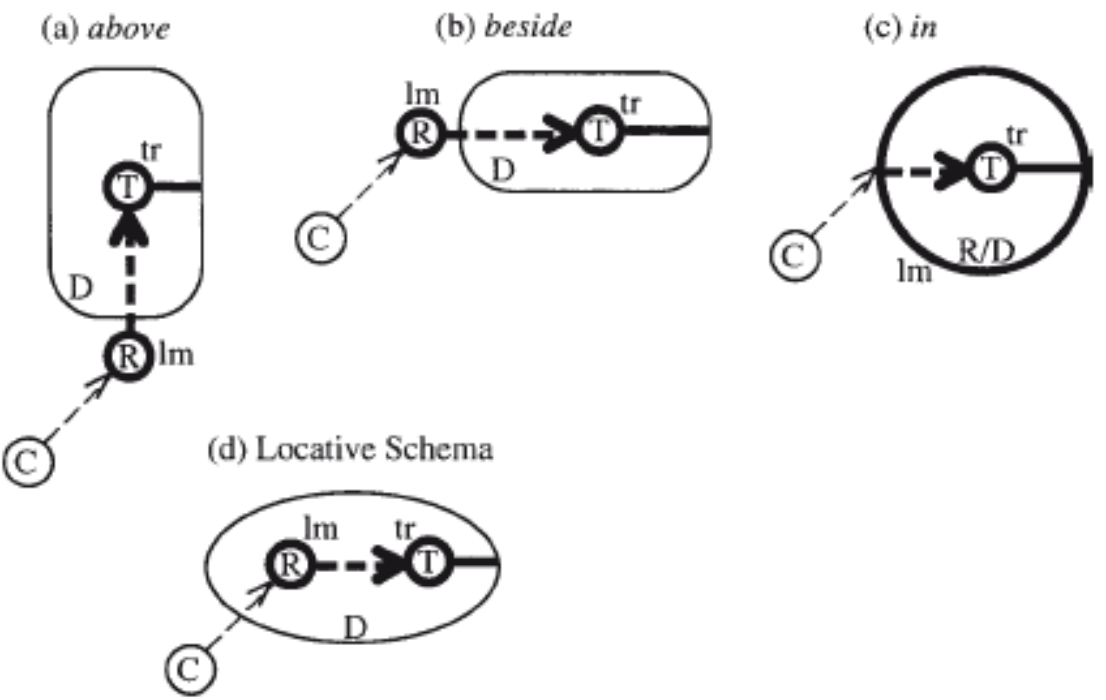

Figura 7: Representações das preposições above, beside, in e representação esquemática locativa. (LANGACKER, 2009, p.100)

Em uma sentença como 'o caderno está ao lado do computador', 'computador' é o ponto de referência a partir do qual o alvo (o caderno) pode ser localizado dentro da região delimitada (ao lado). Já numa sentença como 'a blusa está no armário', 'armário' identifica tanto o domínio de busca quanto o ponto de referência dentro do qual a blusa pode ser encontrada.

É importante notar que a entidade que é o marco é evocada, não como um local em si, mas como o ponto de referência para definir esse local que, por sua vez, é definido pela própria preposição. Como aspecto distintivo de seu significado, cada preposição espacial especifica uma região no espaço caracterizada em relação ao marco e dentro da qual o trajetor pode ser localizado: em in, a região interior; em beside, a região adjacente a ele; em near, a região vizinha, etc. (LANGACKER, 2010).

Uma forma de construções existenciais ou locativas serem apropriadas como possessivos é ilustrada por Langacker (2009) através da construção existencial de posse do japonês: 
$\begin{array}{lll}\text { (99) a. } & \text { watashi-ni-wa } & \text { mago-ga } \\ \text { 1SG-DAT-TOP } & \text { neto-NOM } & \text { existe } \\ \text { Eu tenho um neto. (lit. 'exite um neto para mim') }\end{array}$

A terminação -ni em japonês, além de marcar sentidos como 'para', também marca objetos indiretos. Seguindo a caracterização conceitual delineada em relação a locativos, em watashi-ni 'para mim', a primeira pessoa do singular, o marco, serve como ponto de referência para localizar o alvo, o trajetor. Na sentença acima, a entidade que existe (o neto) coincide com o alvo, a entidade que é localizada em relação ao falante de primeira pessoa. Da mesma maneira, o domínio de existência é identificado com o domínio de busca onde o alvo pode ser localizado.

Dessa forma, a construção serve para localizar o domínio de existência de forma que o alvo existe especificamente na região ancorada pelo participante posposicionado, o falante de primeira pessoa (LANGACKER, 2009).

Interessantemente, como nota o autor, essa região não é necessariamente espacial, já que a própria marca de objeto indireto é frequentemente experiencial por natureza, de forma que o principal sentido trazido pela construção no japonês é aquela que o neto existe no domínio de experiência do falante. Sentido esse diretamente ligado à posse que também salienta o acesso experiencial (LANGACKER, 2009). ${ }^{113}$

Resulta dessa caracterização que possessivos e locativos compartilhariam uma caracterização conceitual abstrata baseada na capacidade de ponto de referência. Como observa o autor, mesmo que aterrados em diferentes arquétipos conceituais, refletidos em seus protótipos, cada arquétipo incorporaria de forma imanente essa capacidade cognitiva (podendo ser apenas o que resta conforme a construção é estendida a casos mais periféricos), o que não impede que as línguas usem formas diferentes para fazer uso dessa estratégia (por exemplo, utilizando a cópula em vez de um verbo existencial como no japonês).

\footnotetext{
113 Langacker (2009) ainda nota que a construção do japonês pode estar sofrendo um processo de reanálise, já que é apontado na literatura que certas propriedades atribuídas a sujeitos estão divididas entre o argumento marcado por -ga (que normalmente marca sujeitos) e o participante marcado com ni (o objeto indireto). Para o autor, isso pode indicar que a construção existencial/locativa com iru está sendo reanalisada como uma construção possessiva com 'ter', em que o perfil está se deslocando de uma relação em que $T$ está localizado em relação a $R$ para uma relação em que $R$ controla $T$, ocasionando (ou sendo instigado) por um mudança em proeminência focal em que R é o trajetor e T o marco.
} 
Vimos anteriormente que no caso do desenvolvimento de verbos de controle físico a verbos de posse como 'ter', haveria uma atenuação em relação à noção de controle por parte de $\mathrm{R}$, restando apenas seu papel passivo como um ponto de referência espacial. No caso do desenvolvimento diacrônico que resultaria em uma expressão locativa vindo a indicar uma relação possessiva, o inverso aconteceria, pois o papel ativo de $\mathrm{R}$ seria fortalecido, assim, em vez de servir apenas como um ponto de referência espacial, $\mathrm{R}$ se tornaria mais ativo na medida em que teria um acesso a $\mathrm{T}$ físico, social e experiencial, predominando fatores experienciais.

Como observa Langacker, os dois caminhos de gramaticalização viriam de dois pontos de início evolutivo diferentes, um em que há uma atenuação do papel de $\mathrm{R}$ em relação a um verbo essencialmente agentivo, e outro em que haveria um fortalecimento do papel de R a partir de uma preposição/posposição espacial.

Interessantemente, esse processo envolveria um mapeamento metafórico entre diferentes domínios, de modo que um local em uma região espacial ancorada por um marco constituiria o domínio fonte, sendo projetado metaforicamente no domínio alvo que seria alguma coisa dentro da esfera de controle do possuidor. Esse mapeamento metafórico envolveria justamente a concepção de que proximidade espacial a algo permite seu acesso e controle, i.e., é a partir de alguma coisa estando próxima a nós espacialmente que seria possível usá-la ou experienciá-la (LANGACKER, 2009).

\subsubsection{Verbos ontológicos}

O próximo grupo é o de verbos ontológicos, representado particularmente pelo verbo hgavs 'parecer, ser similar, assemelhar-se' em georgiano. Os exemplos a seguir, ilustram seu uso: 
(100)

chven-i sxeul-i bevri ramit h-gav-s

nosso-NOM corpo-NOM muito alguma.coisa 3BDAT-ser.similar-3ANOM.SG

cxovel-is sxeul-s

animal-GEN corpo-DAT

Em muitos aspectos, nosso corpo se assemelha ao corpo do animal. ${ }^{114}$

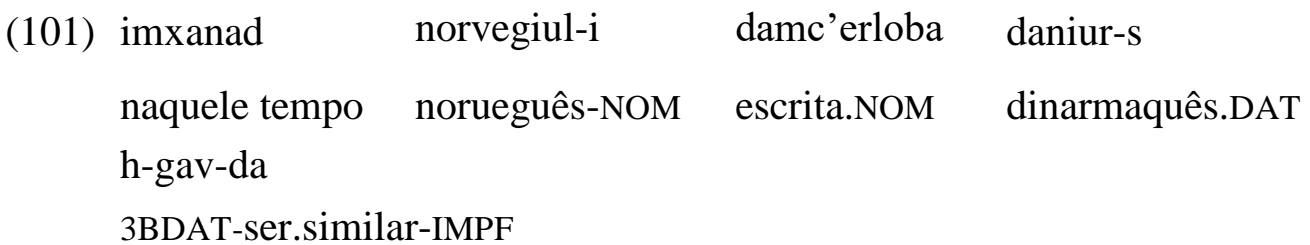

Naquela época, a escrita norueguesa era similar à dinarmaquesa. ${ }^{115}$

A marcação desse tipo de verbo com o dativo é interessante de um ponto de vista conceitual. Como Croft (1993) argumenta, eventos como lutar, dançar e encontrar, assim como eventos que denotam similaridade ou dissimilaridade, são simétricos, isto é, diferentemente de um evento causal que é assimétrico na medida em que há transmissão de energia de um participante a outro, havendo uma direcionalidade causal e assimétrica entre os participantes, em que um é a fonte de energia do evento; em eventos simétricos, como o exemplo dado pelo autor 'Os alemães e os russos lutaram (uns com os outros)', não há uma força causal no sentido de um dos participantes ser a força iniciadora do evento como em 'O João chutou a bola'.

Naturalmente, mesmo eventos simétricos, quando codificados através da língua e suas estruturas, podem ser construídos de forma que um participante receba uma maior saliência e seja tido como aquele que parece mais controlar o evento (normalmente o sujeito), como em construções com um deles sendo marcado de forma oblíqua 'Os alemães lutaram com os russos', nesses casos, uma das direções desses eventos simétricos é mantida no background para que o evento se adapte à estrutura transitiva, prototípica de eventos causais (CROFT, 1993). ${ }^{116}$

Note que em eventos simétricos de similaridade, essa característica simétrica se faz bastante presente na medida em que, conceitualmente, um evento em que João se

\footnotetext{
${ }^{114}$ Exemplo retirado de: https://wol.jw.org/ka/wol/d/r20/lp-ge/2015008

${ }^{115}$ Exemplo retirado de: https://wol.jw.org/ka/wol/d/r20/lp-ge/302012000

${ }^{116}$ É interessante notar também a marcação desses eventos através de construções médias 'eles se assemelham, eles se encontraram' ou mesmo de construções intransitivas não marcadas como 'eles lutaram, eles dançaram'.
} 
assemelha ou se parece com o Pedro implica de alguma forma que Pedro se assemelha ou se parece com o João. Dessa forma, é esperado que haja certa variação em termos de proeminência e marcação desses participantes, em que o participante marcado, por exemplo, em uma construção como oblíquo, ou mesmo como dativo, pode eventualmente ser tomado como mais proeminente, ainda mais se acompanhado de outras propriedades semânticas salientes como animacidade.

Como Janda (1993, p. 69) menciona, a justaposição de duas entidades com uma capacidade similar de agentividade (como é o caso de participantes conceitualmente salientes, cada qual ao seu modo, como experienciadores e estímulos) implica uma disputa por uma maior proeminência em termos de codificação. No caso de verbos de similaridade, ambos os participantes têm uma força aproximada, favorecendo a marcação de um ou de outro como mais saliente e acabando por se adequar a uma construção transitiva na medida em que apenas um receba maior proeminência.

Um exemplo interessante dessa 'disputa' é que, apesar de os verbos acima terem uma morfologia indireta, no sentido de serem marcados através das Séries tal como verbos indiretos usualmente o são, o nominativo aparece nos dois exemplos em posição inicial (em vez do dativo), indicando ainda mais o quanto esses eventos apresentam certa fluidez e simetricidade na proeminência de seus participantes.

\subsubsection{Verbos atitudinais}

Verbos atitudinais como emet'eba 'ser generoso', echkareba 'estar com pressa' e calia 'ter tempo livre' são de difícil caracterização em comparação àqueles vistos até aqui, tendo em comum indicarem disposições ou atitudes em relação a algo, talvez daí a marcação dativa do participante, já que não deixam de ser um estado de espírito ou um estado mental que esse participante experiencia. 
(102)

dzalian m-e-chkar-eb-a!

muito 3BDAT-VPR-ter.pressa- ST-3ANOM

she-g-i-dzl-i-a-t sc'rapad c'axvidet?

PV-2BDAT-VPR-poder-ST-3ANOM-PL rapidamente ir

Estou com muita pressa! Você (forma de plural polida) pode ir rápido? ${ }^{117}$

Esses verbos diferem daqueles classificados como atitudinais por Barðdal (2011) em islandês tais como fara vel 'servir bem', vera best 'ser bom para alguém', vera dul ‘ser impossível', etc.

Talvez mais se assemelhassem a esses eventos aqueles que denotam propriedades do indivíduo, como o exemplo do islandês abaixo:

$\begin{array}{llll}\text { (103) honum } \quad \text { liggur } & \text { hátt } & \text { rómur } \\ \text { 3PL.DAT jaz } & \text { alto.ADV } & \text { voz.NOM } \\ \text { Ele tem uma voz alta. (Lit.: uma voz alta jaz nele/para ele) (BARĐDAL, 2011, } \\ \text { p.66) }\end{array}$

Já que, assim como podemos 'ter uma voz alta', também poderíamos 'ter generosidade, ter pressa ou tempo livre'. Por essa perspectiva, esses eventos parecem ser tomados como propriedades que existem para o indivíduo ou que, literalmente como no exemplo, jazem nele. O que é particularmente interessante, pois o dativo parece ser conceitualizado, como temos visto, como um local onde existe a propriedade ou mesmo onde ela está ou é trazida.

\subsubsection{Verbos desiderativos e verbos de julgamento}

O grupo de verbos indiretos desiderativos, como mencionado anteriormente, é particularmente produtivo, de modo a atrair novos lexemas verbais. Esses verbos, assim,

${ }^{117}$ Exemplo retirado de: https://wol.jw.org/ka/wol/d/r20/lp-ge/2010922 
são frequentemente derivados de outras Classes de verbos diretos, normalmente volitivos, passando a exprimir uma vontade ou desejo não controlável de fazer aquela ação. Dessa forma, o participante marcado com o caso dativo experiencia o evento denotado pela raiz do verbo de forma não volitiva, não tendo controle sobre a ação.

São exemplos de verbos desiderativos: o verbo emghereba 'sentir vontade de cantar, estar no humor de cantar', derivado do verbo de Classe III v-mgher-i 'eu canto'; ecek'veba 'sentir desejo de dançar', derivado do verbo de Classe III v-cek'v-av 'eu danço'; ecineba 'sentir desejo de rir', derivado do verbo de Classe III $v$ - $i$-cin- $i$ 'eu rio'); dentre outros. Observe que nesses casos, diferentemente de suas versões diretas, verbos como $e$-cin-eb-a 'sentir vontade de rir' e $e$-ghim-eb-a 'sentir vontade de sorrir' não apenas denotam o evento de rir ou sorrir, mas indicam que essa ação é incontrolável ou não intencional (de rir ou sorrir, respectivamente), em que o experienciador não pode controlar o riso ou sorriso.

No caso georgiano, torna-se claro que a estrutura construcional formada através da vogal pré-radical - $e$ - (marcando um nominal dativo) em adição ao sufixo temático $e b$-, e relacionada ao aspecto da não volicionalidade também encontrado em outros verbos experienciais de mesma estrutura, atua como uma forma de derivação modal ao indicar uma leitura de desejo ou uma vontade não intencional de realizar a ação denotada pela raiz.

Em termos de família de construções, a volicionalidade tem um papel fundamental na conexão entre as diferentes construções indiretas e também em relação às construções diretas no georgiano, já que formam contrastes entre eventos mais e menos volitivos.

Esse contraste observado em georgiano, também se verifica em outras línguas através de uma marcação canônica e não canônica.

Em quéchua (imbabura), uma língua nominativo-acusativa, além de verbos experienciais tais como nanana 'sentir dor' em que o experienciador é marcado não canonicamente (nesse caso, com o caso acusativo), há também o sufixo desiderativo naya- que seleciona uma marcação acusativa no experienciador (HERMON, 2001).

Esse sufixo pode ser adicionado tanto a verbos quando a nomes: 
$\begin{array}{lll}\text { (104) a. } & \text { ñka-ta-ka } & \text { puña-naya-rka } \\ & \text { 1SG-ACC-TOP } & \text { dormir-DESID-PAST.3SG }\end{array}$

Eu quero dormir. (HERMON, 2001, p.152)

b. ñuka-ta yaku-naya-wanmi

1SG-ACC água-DESID-PRES.3SG

Eu sinto desejo de água (tenho sede). (HERMON, 2001, p.153)

É interessante notar que essas construções com o sufixo -naya- contrastam em termos de volicionalidade com construções marcadas com o sufixo -chi-, que marca na língua causalidade. Esse sufixo seleciona um argumento marcado canonicamente e indica maior controle sobre a ação (HERMON, 2001), observe os pares abaixo:

\author{
(105) a. miku-naya-wanmi \\ comer-DESIS-PRES.3SG \\ Eu tenho fome (sinto vontade de comer). (HERMON, 2001, p.157) \\ b. miku-naya-chi-ni \\ comer-DESIS-CAUS-PRES.1SG \\ Eu quero comer. (HERMON, 2001, p.152)
}

Em (105b), segundo Hermon (2001), o falante enfatiza que deseja realizar a ação de forma intencional, já em (105a), é enfatizado o fato de o falante ter uma vontade fisiológica incontrolável de comer.

Como veremos na seção 5.5, o contraste entre graus de volicionalidade é bastante saliente entre construções indiretas e diretas em georgiano. De forma similar aos exemplos do quéchua, em georgiano, as construções transitivas, ou as causativas não marcadas, são também responsáveis por leituras mais agentivas de alguns eventos, da mesma forma que o dativo, e demais características morfológicas associadas, está ligado a leituras não volitivas.

Antes, no entanto, de finalizarmos esta discussão, resta falar sobre o grupo de verbos de julgamento, estes também associados à estrutura com a vogal pré-radical -e- 
mais sufixo temático -eb-. Nesses casos, a derivação é feita através de adjetivos, a forma derivada expressando um julgamento ou opinião do participante dativo em relação ao nominal nominativo ter aquela qualidade expressa pela raiz do adjetivo.

Dessa forma, um verbo, por exemplo, como e-advil-eb-a 'achar que alguma coisa é fácil' é derivado do adjetivo advili 'fácil'. Interessantemente, esses verbos assemelham-se a verbos experienciais cognitivos no sentido de manifestarem um pensamento acerca de algo. Nesse ponto, uma nuance experiencial é adicionada ao significado desses verbos deadjetivais, isto é, o participante dativo experiencia um processo mental acerca de algo.

\subsection{DOM: marcação diferencial de objeto}

Embora não tratemos diretamente nesta tese de marcações não canônicas do objeto, em especial do estímulo, interessa-nos fazer algumas considerações a esse respeito, visando a caracterição conceitual dos eventos experienciais.

Assim, tal como fizemos na seção 5.3.2 ao apontar e comentar sobre a marcação não canônica do estímulo do verbo perceptual 'olhar', comentaremos nesta seção acerca da marcação do estímulo com o caso genitivo encontrada em alguns verbos experienciais em georgiano e translinguisticamente bastante comum, sendo o genitivo um dos casos usualmente encontrado em marcações não canônicas.

A língua russa, por exemplo, é um caso de língua indo-europeia - e, assim, não aparentada com o georgiano - que apresenta o caso genitivo marcando o estímulo em verbos psicológicos, o exemplo abaixo ilustra o verbo bojat'sja 'ter medo':

$\begin{array}{llll}\text { (106) Ja } & \text { bojus' } & \text { sobak } \\ \text { 1SG.NOM } & \text { temer.1SG } & \text { cachorro.GEN.PL } \\ \text { Eu tenho medo de cachorros. } & \end{array}$

Outros verbos no russo que apresentam essa marcação são (cf. Ryan, 2015; Offord, 2005): 
- verbos de emoções negativas como medo, apreensão e de distância física: bojat'sja 'ter medo', pugat'sja 'assustar-se', opacat'sja 'temer', ctydit'sja 'ter vergonha', stesnjat'sja 'estar tímido, embarassado', lishat'sja 'perder, privar-se de', lishat' 'privar alguém de alguma coisa', storonit'sja 'evitar, afastar-se', chuzhdat'sja 'afastar-se', dichit'sja 'manter-se afastado', izberat' 'evitar', osteregat'sja 'ficar alerta, ter cuidado'. - verbos de desejo, anseio, aspiração ou esforço para conquistar algo: zhelat' 'desejar', dobibat'sja 'esforçar-se, aspirar', zhazhdat' 'ansiar'.

- verbos de conquista ou benefício próprio: dostigat' 'conquistar', zasluzhivat' 'merecer', ctoit' 'merecer', dobit'sja 'conseguir', udostaivat' 'receber, ser recompensado'.

- verbos de contato físico ou proximidade emocional ou intelectual: derzhat'sja 'aderir, segurar-se a', kasat'sja 'tocar, interessar-se'.

- verbos de obedecimento: slushat'sja 'obedecer' (cf. em latgálio (língua báltica) klauseit + GEN est $^{\text {'obedecer}) .}{ }^{118}$

Alguns verbos no russo, tais como dozhidat'sja 'esperar até', zhdat' 'esperar por', iskat' 'procurar por' (cf. lituano ieškoti + GEN est 'procurar por'), prosit' 'esperar', trebovat' 'precisar' e xotet' 'querer', apresentam variação entre marcar o objeto como acusativo ou genitivo, sem uma definição muito precisa de quando um ou outro é usado (OFFORD, 2005). ${ }^{119}$

Línguas bálticas como o lituano apresentam situação similar ao russo. Em lituano, verbos como bijoti 'ter medo', išsigasti 'assustar-se', šalintis 'evitar', saugotis ‘ficar alerta, ter cuidado' também têm o estímulo marcado com o caso genitivo. Outros verbos com mesma marcação de genitivo e semântica similar aos verbos russos de anseio e desejo são noreti 'querer', siekti 'esforçar-se', trokšti, geisti 'desejar', ilgetis 'ansiar' (SERZHANT, 2014, p. 290).

Observe a semelhança principalmente entre o primeiro grupo listado de verbos no russo, de emoções negativas (também presente em lituano), com os verbos no georgiano que também marcam o estímulo com o genitivo, tais como: eshinia 'ter medo', scxvenia 'ter vergonha', erideba 'sentir-se tímido, embaraçado', shurs 'ter inveja'. Esses verbos têm em comum a denotação de uma experiência emocional que é mais negativa de se sentir.

\footnotetext{
${ }^{118}$ Em uso coloquial, o verbo clushat'cja 'obedecer' pode ter o estímulo marcado com o caso acusativo. ${ }^{119}$ Como comenta o autor, uma hipótese é a de que o genitivo seria usado com referentes abstratos ou gerais, enquanto o acusativo seria mais usado com referentes particulares e concretos como uma coisa ou pessoa específicos (cf. também Janda \& Divjak (2015) para uma explicação similar).
} 
Essa nuance negativa do evento experiencial em conjunto com uma marcação diferencial do estímulo não se restringe, no entanto, ao russo e georgiano apenas, sendo encontrada em outras línguas, o que torna o fenômeno ainda mais interessante do ponto de vista de sua conceitualização.

Nas línguas leste-caucasianas (não aparentadas com as línguas sul-caucasianas e das quais o georgiano faz parte), por exemplo, o estímulo do verbo 'ter medo' é frequentemente marcado com um caso locativo, o que, a princípio, constrasta com a marcação de outros objetos nessas línguas. Nas línguas agul, lezguiano e tabasaran, o experienciador de 'ter medo' é marcado com o caso dativo e o estímulo com o caso postelativo ((107) e (108a)), enquanto um verbo experiencial como 'ver' teria o experienciador marcado com o caso dativo e o estímulo com o caso absolutivo (108b) (cf. Haspelmath, 1993; Ganenkov, 2006):

Tabasaran:

$$
\begin{array}{lll}
\text { uzu-z } & \text { Xu-jir.i-qan } & \text { guch'ura } \\
\text { 1SG-DAT } & \text { cachorro-PL-POSTEL } & \text { ter medo }
\end{array}
$$

Eu tenho medo de cachorros. (GANENKOV, 2006, p.187)

Lezguiano:

$\begin{array}{llll}\text { (108) a. } & \text { za-z } & \text { wa-q }{ }^{\mathrm{h} a j} & \text { kich'e-zwa } \\ & \text { 1SG-DAT você-POSTEL } & \text { ter.medo.IMPF } \\ & \text { Eu tenho medo de você. (HASPELMATH, 1993, p.138) }\end{array}$

Ademais, em lezguiano, há outros verbos com marcação similar: o verbo reghü 'ter vergonha', tendo também o estímulo marcado com o caso postelativo; e o verbo bejkef 'ter raiva', apresentando o estímulo marcado com outro caso locativo, o subelativo (HASPELMATH, 1993).

Em outras línguas leste-caucasianas, como andi, akhvakh, archi, akusha dargi, avar, bagwalal, chechen, chamalal, godoberi, icari dargi, karata, ingush, lak, tsakhur e 
tsez, a marcação do predicado 'ter medo' apresentaria o experienciador no absolutivo (ou nominativo a depender da nomenclatura do autor) e o estímulo com um caso locativo tal como lezguiano e tabasaran vistos acima (cf. Ganenkov, 2006).

Indo mais longe, para as línguas indo-europeias, também é possível encontrar casos em que o estímulo de emoções negativas é marcado diferencialmente. No latim, a conhecida construção com o experienciador no caso acusativo e o estímulo no caso genitivo codificava um pequeno grupo de verbos experienciais com semântica negativa ou desagradável, tais como: pudet 'ter vergonha', taedet 'ter tédio', miseret 'ter pena', piget 'estar aborrecido, ter pena, arrependimento', paenitet 'arrepender-se':

$$
\begin{array}{llll}
\text { me } & \text { paenitet } & \text { eius } & \text { rei } \\
\text { 1SG-ACC } & \text { arrepender.se.3SG.PRES } & \text { essa } & \text { coisa.GEN } \\
\text { Eu me arrependo disso. } & \text { (FEDRIANI, } & \text { 2014, } & \text { p.198) }
\end{array}
$$

Em português, como comentado na seção 3.2, o estímulo de verbos experienciais com semântica negativa é marcado com uma preposição distinta daquela usada com semântica mais positiva ou que denota mais empatia. Repetiremos os dados aqui por conveniência:

(110) a. O João tem/sente medo de cobra.

b. O João tem/sente raiva de cobra.

c. O João tem/sente ódio de cobra.

d. O João tem/sente nojo de cobra.

e. O João tem/sente inveja do Pedro.

f. O João tem/(sente?) receio de cobra.

g. O João tem/sente vergonha do Pedro.

Versus:

(111) a. O João tem/sente amor por animais.

b. O João tem/sente desejo por mulheres. 

c. O João tem gosto por animais.
d. O João tem/sente admiração por mulheres.
e. O João tem/sente apreço pelo Pedro.
f. O João tem/sente receio pelo filho.
g. O João sente vergonha pelo Pedro.

O que podemos concluir a partir dos dados observados é que parece haver uma tendência tipológica de marcar o estímulo diferencialmente quando o evento experiencial é percebido como mais negativo.

Do ponto de vista conceitual, essa tendência serve como indício de como eventos experienciais são conceitualizados. Em eventos como 'ter medo' e 'ter vergonha', verbos presentes na maior parte das línguas observadas anteriormente, o experienciador não dirige necessariamente seu medo ou sua vergonha ao estímulo, mas percebe essa emoção como sendo negativamente causada a partir do estímulo.

Por essa perspectiva, predicados como 'ter medo' e 'ter vergonha' traz um significado de afastamento, isto é, de mover-se para longe do estímulo que suscita ou causa aquela emoção negativa ou desagradável no experienciador. Em russo, aliás, essa concepção de afastamento está bem presente no significado dos predicados negativos listados acima.

Essa noção de 'a partir de' ou de 'mover-se para longe de' lembra o significado de casos gramaticais como o ablativo ou outros casos locativos que indicam origem ou afastamento de algum local ou coisa.

Em lezguiano, por exemplo, o postelativo, que marca o estímulo dos verbos reghü 'ter vergonha' e kich'e 'ter medo', marca, em seu domínio mais concreto, a noção locativa de 'a partir de, de, (ingl. from)':

$\begin{array}{llccc}\text { (112) } & \text { masa } & \text { pat-ar.i- } \mathrm{q}^{\mathrm{h}} \text { aj } & \text { ata-j } & \text { insan-ar } \\ & \text { outro } & \text { lado-PL-POSTEL } & \text { vir-PART } & \text { humano-PL } \\ & \text { Pessoas vindas de outros lugares. } & \text { (HASPELMATH, 1993, p.94) }\end{array}$


Em azeri (azerbaijano), uma língua túrquica, o estímulo do verbo qorx 'ter medo' é marcado com o caso ablativo -dan:

$\begin{array}{lll}\text { mən } & \text { siçan-dan } & \text { qorxuram } \\ 1 \text { SG } & \text { rato-ABL } & \text { ter.medo }\end{array}$

Eu tenho medo de rato. ${ }^{120}$

Em contrapartida, outras línguas, em que não há um 'caso ablativo' diferenciado gramaticalmente, há frequentemente uma fusão entre as marcas dos casos genitivo e ablativo, o primeiro tomando as funções do último. O grego antigo é um exemplo (em que o genitivo possuía funções de ablativo), assim como o português, em que a preposição 'de' assume tanto funções relacionadas ao genitivo quanto ao ablativo.

Em inglês, a preposição of, associada em inglês moderno a usos do genitivo e que acompanha o estímulo de verbos experienciais como afraid of, envious of, ashamed of, scared of, tired of, tinha como sentido original o significado de 'away from', expressando justamente noções de separação, afastamento, privação, origem, etc. $(\mathrm{OED})^{121}$.

Apesar das similaridades marcantes apontadas no que se refere à marcação do estímulo de verbos experienciais com semântica mais negativa, é importante notar que cada língua, dentro de seu sistema próprio como um todo, vai mostrar essa codificação diferencial do estímulo de formas peculiares e com contrastes, por vezes, distintos. Por exemplo, em relação à marcação do estímulo com o genitivo, o russo vai agrupar verbos de semântica negativa juntamente com verbos que denotam anseio e desejo, benefício próprio e proximidade.

Essa semântica de 'querer para si', difere do significado de afastamento, de mover-se para longe, presente em verbos de experiência negativa. Ainda assim, em se tratando de marcação menos prototípica do objeto, 'querer para si’ não pressupõe ter, de fato, o objeto, assim como 'olhar' não pressupõe 'ver'. Por essa perspectiva, o desejo ou anseio também é causado a partir do estímulo, assim como o medo ou a vergonha.

\footnotetext{
${ }^{120}$ Fonte: https://azerbaijanilanguage.wordpress.com/2010/08/30/locative-case-genitive-case-dativecase-ablative-case-objective-case/ ${ }^{121}$ Oxford English Dictionary (online): https://www.oed.com/
} 
Essa nuance não difere necessariamente de verbos de benefício próprio e de proximidade, mesmo estes pressupondo algo mais tangível, adquirido ou conquistado, pois a conquista vem a partir daquilo conquistado ou adquirido, isto é, do estímulo.

Em georgiano, os verbos com semântica mais positiva e que marcam o estímulo com o caso genitivo são jers, scams 'acreditar/confiar', como exemplificado abaixo:

$$
\begin{array}{llllll}
\text { me } & \text { ar } & \text { v-amb-ob, } & \text { rom } & \text { amis } & \text { m-jer-a } \\
\text { 1SG } & \text { não } & \text { 1ANOM-dizer-ST } & \text { que } & \text { isso.GEN } & \text { 1BDAT-acreditar-3ANOM }
\end{array}
$$

Eu não estou dizendo que eu acredito nisso. ${ }^{122}$

Ainda que com marcações diferentes, verbos como 'acreditar, confiar' apresentam frequentemente nas línguas marcação diferencial no sujeito (como em bengali), no objeto (finlandês, português), ou mesmo em ambos, como em georgiano acima.

Em português, verbos experienciais como 'acreditar, confiar' e outros com semântica próxima têm o estímulo marcado com a preposição 'em': 'acreditar em, confiar em, crer em, ter fé em, ter esperança em'. ${ }^{123}$ De forma similar, no inglês, a preposição in marca o estímulo do verbo believe em alguns contextos, como em situações em que há crença na existência de algo ou na capacidade de alguém ou na eficiência ou adequabilidade de alguma coisa. Já o padrão transitivo believe something/someone é mais usado referindo-se à verdade ou mentira de determinado fato (relatado através de alguém, por exemplo).

Já em finlandês, o estímulo do verbo 'acreditar, confiar' é marcado com o caso ilativo, um caso locativo que significa 'em, para dentro de':
$(115)$
a. hän usko-o sii-hen
3SG.NOM acreditar-3SG isso.ILL
Ele/ela acredita nisso. (SANDS \& CAMPBELL, 2001, p. 286).

\footnotetext{
${ }^{122}$ Fonte: http://forum.tsu.ge/lofiversion/index.php?t1527.html

${ }^{123}$ Outro verbo experiencial em português que também marca o estímulo com a preposição 'em' é o verbo cognitivo 'pensar em'.
} 

b. minä luota-n sinu-un
1SG.NOM confiar-1SG você.ILL
Eu confio em você. (SANDS \& CAMPBELL, 2001, p. 286).

Em lituano e letão, a situação é ainda mais diversa, enquanto em lituano o estímulo de 'acreditar' é marcado com o instrumental, em letão é marcado com o caso dativo, sendo o primeiro uma inovação do lituano (i.e., marcação não encontrada em lituano antigo) (HOLVOET \& NAU, 2014, p.5).

Qualquer que seja a motivação para esse tipo de marcação diferencial no verbo 'acreditar' em cada uma dessas línguas (discussão que vai além do escopo imediato desta seção) interessa notar que entre a diversidade, há uma saliente similaridade, esta justamente sendo a marcação diferencial observada no evento experiencial 'acreditar' presente em grupos de línguas bastante diversos tipologicamente. Dado esse que indica que de alguma forma as línguas tentam captar o papel distintivo desempenhado pelo experienciador e pelo estímulo no evento de 'acreditar', tal como ocorre com outros predicados experienciais que temos visto até aqui.

Voltando aos dados do português, em comparação com o russo e georgiano, a diferença entre a marcação de emoções negativas e positivas é mais marcada e indica nuances de significado distintas entre esses dois grupos. Com os verbos experienciais positivos, o grau de empatia é mais acentuado e a emoção é direcionada ao estímulo, diferindo dos eventos negativos em que a experiência é tida como negativamente vindo a partir do estímulo.

Uma exceção, no entanto, deve ser notada, que é o verbo 'orgulhar-se de' em português, a princípio, 'ter/sentir orgulho de alguém' é uma emoção mais positivamente avaliada do que, por exemplo, 'ser orgulhoso'. De fato, o termo 'orgulho' é complexo não só linguística e culturalmente falando, mas também internamente às línguas, já que há diferentes concepções de orgulho e com diferentes graus de avaliação positiva ou negativa.

Por exemplo, haveria o 'orgulho' orientado a si mesmo que pode tanto significar um sentimento de satisfação e autoestima relacionado ao próprio valor do indivíduo e suas conquistas, sendo mais positivo; quanto um sentimento exacerbado de orgulho de si próprio, mais negativo, levando à arrogância e irredutibilidade. Na esfera mais 
positiva, há também o orgulho que é orientado ao outro, este normalmente tido como mais positivo.

As nuances mais positivas em português são usualmente aquelas orientadas ao outro ou a aspectos de si próprio como 'ele tem orgulho do filho', 'ele tem orgulho de seus talentos', já as nuances mais negativas são mais salientes em construções como 'ele é orgulhoso', denotando uma característica do indivíduo, voltada a ele próprio. Naturalmente, com o contexto e adição de outros elementos, essas nuances apontadas podem ser enfatizadas ou diminuídas.

Em koasati, como informa Kimball (1991), as nuances mais positivas de 'orgulho' não estão presentes no termo equivalente ou aproximado ilakasá:mon que, apesar de ser usado para indicar que o indivíduo tem orgulho de suas habilidades ou talentos, esse orgulho é visto como negativo, pois faz com que esse indivíduo trate os outros de forma ruim, sendo mais aproximado à concepção grega de hubris.

Já em georgiano, a situação é um pouco mais similar ao português, pois a mesma raiz amaq 'orgulho' pode ter sentidos mais negativos e positivos a depender do contexto ou da construção usada.

$\mathrm{O}$ verbo indireto $e$-amaq-eb-a 'estar orgulhoso' é frequentemente encontrado com complementos sentenciais introduzidos por rom como no exemplo abaixo (116a e b), mas também pode ser encontrado com um complemento nominativo denotando o estímulo (em 117):

$\begin{array}{lll}\text { a. m-e-amaq-eb-a, } & \text { rom } & \text { sxvebis-gan } \\ \text { 1BDAT-VPR-ter.orgulho-ST-3ANOM } & \text { que } & \text { outros-POSP } \\ \text { gan-v-sxvavd-eb-i } & & \end{array}$

PV-1ANOM-diferenciar-ST-SM

Eu tenho orgulho de ser diferente dos outros. ${ }^{124}$

$\begin{array}{lllll}\text { b. kmar-s } & \text { e-amaq-eb-oda, } & \text { rom misi } & \text { col-i tavisi } \\ \text { marido-DAT } & \text { VPR-ter.orgulho-ST-IMPF } & \text { que dele } & \text { esposa-NOM próprio } \\ \text { rc'men-isa } & \text { da } \quad \text { sindis-is } & \text { tanaxmad } & \text { mo-ikc-a } \\ \text { fé-GEN } & \text { e } \quad \text { consciência-GEN } & \text { de acordo } & \text { PV-agir-3ANOM.AOR } \\ \text { O marido estava orgulhoso de que sua esposa agiu de acordo com sua } \\ \text { própria fé e consciência. }{ }^{125}\end{array}$

\footnotetext{
${ }^{124}$ Fonte: https://wol.jw.org/ka/wol/d/r20/lp-ge/102006369

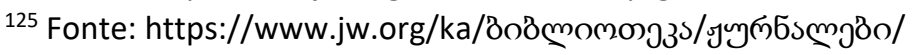



(117) mat e-amaq-eb-a-t
gmir-eb-i
3PL.DAT VPR-ter.orgulho-ST-3ANOM-PL heróis-PL-NOM

Eu tenho orgulho dos heróis. ${ }^{126}$

Interessantemente, há um verbo de Classe 3 amaq-ob 'orgulhar-se' que é também usado com sentido similar, nesse caso, o estímulo é marcado com o instrumental:

(118) a. shen-it v-amaq-ob

2SG.INST 1ANOM-ter.orgulho-ST

Eu tenho orgulho de você. ${ }^{127}$
b. chemi kmr-it v-amaq-ob
meu marido-INST 1ANOM-ter.orgulho-ST
Eu tenho orgulho do meu marido. ${ }^{128}$

Os exemplos vistos até o momento são de um orgulho mais positivo, principalmente aqueles em que o orgulho é orientado a outros. $\mathrm{O}$ orgulho negativo é dado contextualmente, principalmente quando acompanhado de outros substantivos negativos, observe:

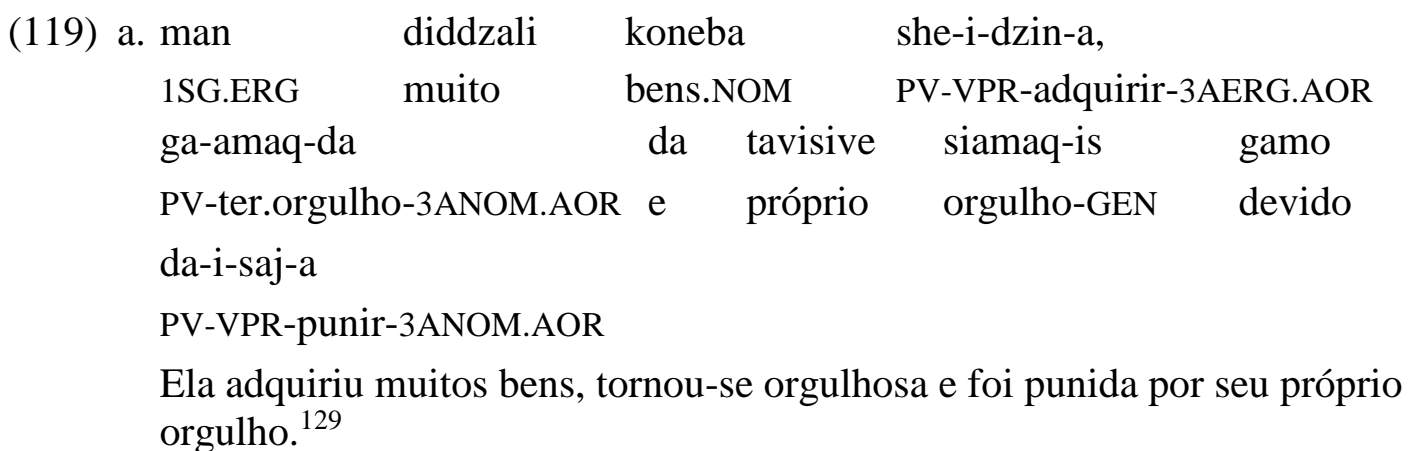

\footnotetext{
${ }^{126}$ https://saba.com.ge/books/

127 https://fanebi.com > nasris-gerlphrendi/

128 https://translate.academic.ru/

129 https://wol.jw.org/ka/wol/d/r20/lp-ge/1102000039
} 
b. v-grdzn-ob, rom chem-shi aghar aris dzveleburi 1ANOM-sentir-ST que mim-POSP não mais 3SG.COP antigo egoizmi da siamaqe egoísmo.NOM e orgulho.NOM

Eu sinto que não há mais em mim o antigo egoísmo e orgulho. ${ }^{130}$

c. sinamdvile-shi tavsheuk'avebeli, agresiuli, amaqi verdade-POSP incontrolável agressivo.NOM orgulhoso.NOM ambiciuri da jiut'i v-iqavi ambicioso.NOM e teimoso.NOM 1ANOM-ser.AOR

$\mathrm{Na}$ verdade, eu era incontrolável, agressivo, orgulhoso, ambicioso e teimoso. ${ }^{131}$

Dada a ambiguidade, entre uma emoção avaliada como positiva ou negativa, do termo ‘orgulho' nas línguas e entre as línguas como vimos, é esperado que haja certa variação na forma como essa emoção é codificada.

Talvez essa variação na interpretação do evento de 'orgulhar-se' como positivo ou negativo explique o porquê de no português 'ter/sentir orgulho de' tenha o estímulo marcado com a mesma preposição usada para marcar o estímulo de outros eventos experienciais negativos.

Outra explicação para 'ter orgulho $d e$ ' pode ser que, apesar de ser uma forma de orgulho orientada ao outro ou parte de si mesmo, essa emoção é vista como sendo causada a partir de alguma característica do estímulo que torna o experienciador orgulhoso.

Essa possibilidade talvez também esteja presente em georgiano de certa forma. Como foi comentado anteriormente, a forma verbal amaqob tem o estímulo, quando presente, marcado com o instrumental. $\mathrm{O}$ instrumental em georgiano usualmente tem o sentido de 'por meio de, com' designando o instrumento por meio do qual uma ação é realizada. Por essa perspectiva, em um domínio mais abstrato, o estímulo teria algo por meio do qual o experienciador teria o orgulho despertado.

130 https://wol.jw.org/ka/wol/d/r20/lp-ge/2010330
131 https://wol.jw.org/ka/wol/d/r20/lp-ge/2010810 
Desse modo, mesmo que de formas diferentes, tanto o georgiano quanto o português parecem salientar que alguma característica do estímulo de 'orgulhar-se' despertaria no experienciador essa emoção. ${ }^{132}$

\subsection{A importância da noção de volição em construções marcadas não canonicamente}

Da discussão feita até o momento, já deve ter ficado em evidência a importância que o aspecto da volição tem em construções marcadas não canonicamente, tanto em georgiano quanto em outras línguas.

O que já foi notado na literatura em outras línguas, e válido também para o georgiano, é o contraste semântico envolvendo aspectos como volicionalidade entre construções marcadas canonicamente e aquelas marcadas não canonicamente.

Butt (2006), por exemplo, nota o contraste semântico entre casos mais canônicos como o ergativo e nominativo e casos não canônicos de sujeito como o dativo e o genitivo nas línguas. A autora argumenta sobre a necessidade de se levar em consideração, na explicação do uso e variação desses casos, parâmetros semânticos no lugar de uma abordagem puramente estrutural de casos gramaticais, estando esses fatores semânticos na raiz de alternâncias semânticas. A autora cita exemplos de línguas como urdu, malaiala e bengali, cada qual com seu sistema de casos e, assim, contrastes, apontando para a necessidade de se olhar a gramática das línguas como um todo.

Em urdu, abaixo, o caso ergativo sinaliza maior controle sobre o evento de 'querer', enquanto o caso dativo expressa desejo ou necessidade:

(120) a. nadya-ko

$\mathrm{zu}$

ja-na

he

Nadya.FEM.SG-DAT zoológico.MASC.SG.LOC ir-INF.MASC.SG ser.PRES.3SG

Nadya precisa/deseja ir ao zoológico. (BUTT, 2006, p.71)

\footnotetext{
1320 mesmo poderia ser argumentado a respeito de 'sentir falta de, ter saudades de' no português.
} 
b. nadya-ne zu ja-na he

Nadya.FEM.SG-ERG zoológico.MASC.SG.LOC ir-INF.MASC.SG ser.PRES.3SG

Nadya quer ir ao zoológico. (BUTT, 2006, p.71)

Contraste parecido também é notado em malaiala e cingalês entre os casos nominativo (não há caso ergativo nas línguas) e dativo, respectivamente:
a. amma
kuTTiye
aTik'k'-aNam
mãe.NOM
criança.ACC
bater-querer

A mãe deve bater na criança. (MOHANAN \& MOHANAN, 1990, p.45)
b. ammak'k'A kuTTiye aTik'k'-aNam
mãe.DAT criança.ACC bater-querer

A mãe deseja bater na criança. (MOHANAN \& MOHANAN, 1990, p.45)

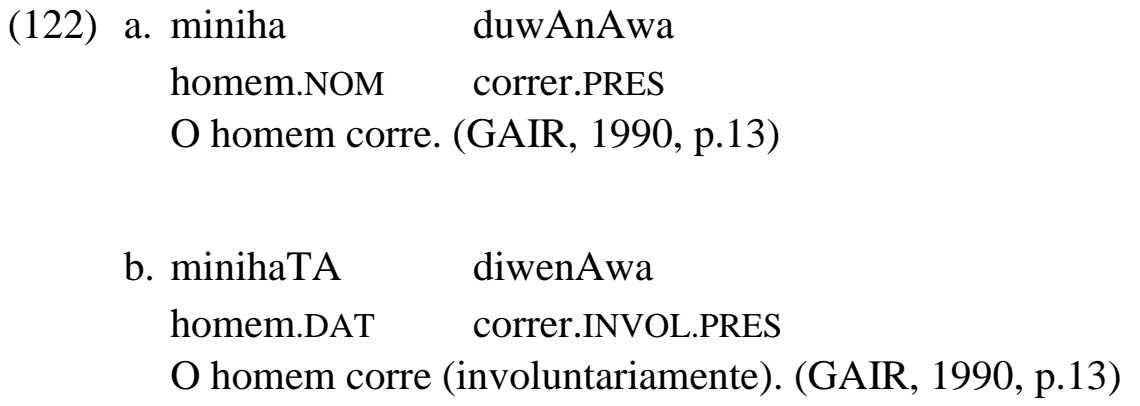

Já em bengali, o contraste se dá entre o caso nominativo e genitivo (o caso genitivo em bengali marca verbos psíquicos (de emoção e de sensação física) na língua (cf. ONISHI, 2001)), sendo o nominativo aquele que codifica o evento mais volitivo:

$\begin{array}{lll}\text { (123) a. ami } & \text { tomake } & \text { cai } \\ \text { 1SG.NOM } & \text { 2SG.ACC } & \text { quer }\end{array}$

Eu quero você. (KLAIMAN, 1980 apud BUTT, 2006, p.74) 
b. amar tomake cai

1SG.GEN 2SG.ACC quer

Eu preciso de você. (KLAIMAN, 1980 apud BUTT, 2006, p.74)

Em georgiano, o contraste entre construções indiretas (com o experienciador no caso dativo em todas as Séries e marcado, no verbo, através das marcas do conjunto B de concordância) e construções diretas (sujeito no nominativo, ergativo ou dativo a depender da Série e sujeito marcado, no verbo, através das marcas do conjunto A de concordância), em que o aspecto de volicionalidade é essencial, mostra-se bastante saliente na gramática da língua.

Vejamos alguns exemplos:

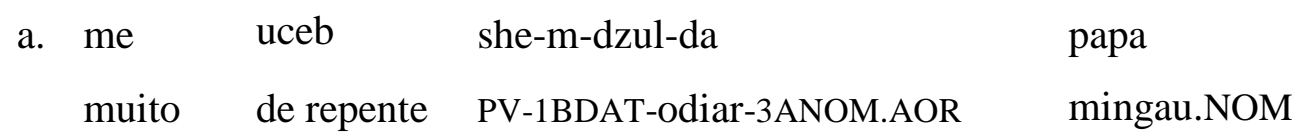

Eu detestei o mingau inesperadamente (não pude controlar). (AMIRIDZE, 2006)

b. me uceb she-v-i-dzul-e papa

muito de repente PV-1AERG-VPR-odiar-3ANOM.AOR mingau.NOM

Eu logo detestei o mingau (deliberadamente). (AMIRIDZE, 2006)

Observe que em (124a) o verbo indireto $d z u l s$ 'odiar' está em seu sentido usual, isto é, indicando a pouca volicionalidade e controle do participante dativo sobre a emoção negativa. Já em (124b), a construção é mais marcada, sendo usada uma construção direta com um verbo de morfologia de Classe I e denotando uma situação em que haveria maior controle da ação por parte do participante marcado com o caso ergativo.

Outros exemplos de pares como o citado acima são as sentenças elicitadas de falantes nativos a seguir:
a. sandro-s u-qvard-eb-a nino
Sandro-DAT VPR-amar-ST-3ANOM Nino.NOM

Sandro está se apaixonando por Nino (mesmo que não queira). 
b. sandro i-quar-eb-s nino-s

Sandro.NOM VPR-amar-ST-3ANOM.SG Nino-DAT

Sandro está se apaixonando por Nino (e está fazendo de propósito).
a. me
she-m-i-qvar-da
musik'a
1SG.DAT PV-1BDAT-VPR-amar-3ANOM.AOR
música.NOM

Eu me apaixonei pela música (sem intenção).

b. me

she-v-i-qvar-e

musik'a

1SG.ERG PV-1AERG-VPR-amar-AOR

música.NOM

Eu me apaixonei pela música (intencionalmente).

Note que no georgiano a mesma raiz pode ser usada com diferentes estruturas morfológicas, carregando diferentes leituras e significados. Tanto no exemplo (125a) quanto em (126a) o verbo utilizado é $u$-qvar- $d$-eb-a 'apaixonar-se', que é um verbo indireto e é a versão incoativa de $u$-qvar-s 'amar', sinalizada pela adição do sufixo $-d$ - à raiz do verbo e morfologia característica de alguns verbos de Classe II (como o sufixo $e b$ - no presente, etc.). Sendo um verbo indireto, com o experienciador no caso dativo, as leituras em (a) são as mais canônicas para esse tipo de verbo.

Os exemplos em (b) são menos usuais e, em adição à morfologia de Classe I, trazem uma nuance de significado em que o participante marcado com o caso ergativo tem mais controle sobre a ação de se apaixonar, fazendo-o intencionalmente.

O próximo exemplo, abaixo, mostra o contraste que vimos, na seção sobre verbos de percepção, entre 'ouvir' e 'escutar':
a. beka-s
e-smin-eb-a
musik'a
Beka-DAT VPR-ouvir-ST-3ANOM
música.NOM

Beka está ouvindo música (mesmo que não queira ou não precise). 

b. beka
u-smen-s
musik'a-s
Beka.NOM VPR-escutar-3ANOM.SG música-DAT
Beka está escutando música (e está fazendo intencionalmente).

Note que no exemplo (127a) (com o verbo indireto) se refere ao evento mais perceptual ou experiencial de ouvir, sem necessariamente, ser uma ação atentiva por parte do experienciador. Já no segundo exemplo (127b), a percepção é mais atentiva e intencional, i.e., o participante dirige sua atenção ao estímulo, a música.

Nós próximos exemplos, o evento é o de 'gostar': no primeiro (128a), é um verbo indireto com o experienciador no dativo, em que a experiência de gostar acontece sem o controle do participante no dativo. Em contraste, de forma similar aos outros exemplos vistos até aqui, o exemplo em (b) tem a nuance de ser um evento mais intencional ou controlável por parte do participante no caso ergativo.
a. mas
mo-e-c'on-a
simghera
3SG.DAT PV-VPR-gostar-3ANOM.AOR
canção.NOM
Ele gostou da canção (sem intenção).
b. man mo-i-c'on-a simghera
3SG.ERG PV-VPR-gostar-3ANOM.AOR canção.NOM
Ele gostou da canção (intencionalmente).

Outros verbos de semântica peculiar, retirados de Asatiani (1998), são os seguintes:

(129) a. mo-v-i-mk'vdarun-e

PV-1AERG-VPR-fingir.de.morto-AOR

Eu me fingi de morto.

b. mo-v-i-gizhian-e

PV-1AERG-VPR-fingir.de.louco-AOR

Eu me fingi de louco. 
c. mo-v-i-sulel-e

PV-1AERG-VPR-agir.como.tolo-AOR

Eu me passei por idiota, agi como um tolo.

d. mo-v-i-mdzinar-e

PV-1AERG-VPR-fingir.domir-AOR

Eu fingi que estava dormindo.

É interessante observar que os verbos acima são todos marcados através de construções diretas com morfologia de Classe I e, por isso, têm seu foco primário indicado, no verbo, através do conjunto A de afixos de concordância e com o caso ergativo no tempo aoristo.

A consequência dessa marcação é que esses eventos carregam um significado de intencionalidade por parte do participante em que ele propositalmente finge estar em determinada condição, o que contrasta com a significação mais típica desses eventos, sendo, normalmente, eventos incontroláveis como 'morrer', 'enlouquecer', 'dormir' (cf. o verbo indireto $d z i n-a v-s$ 'dormir').

Além desses casos - à semelhança do caso visto da língua quéchua acima, em que, de uma leitura mais canonicamente não volitiva de certos eventos, há a possibilidade de se construir esses eventos como mais controláveis por parte do participante, sendo esta possibilidade acompanhada de uma mudança estrutural a depender da língua (como mudança de caso, concordância, etc.) -, haveria também situações em que, de uma leitura mais canonicamente volitiva de eventos, existe a possibilidade de codificação desses eventos como menos volitivos ou intencionais.

Hewitt (1998), por exemplo, observa que há casos em que a mudança de preverbo para shemo, em adição à vogal pré-radical - $e$ - (e em alguns casos a vogal - $a$-) e o sufixo temático -eb-, ocasionaria uma nuance de significado em que o participante dativo se tornaria um agente não intencional. Na tabela abaixo, é possível ver alguns desses verbos: 


\begin{tabular}{|c|}
\hline Verbos codificando eventos não volitivos: \\
\hline $\begin{array}{l}\text { shemo-e-ch'm-eb-a 'ter uma vontade incontrolável de comer, comer } \\
\text { acidentalmente, sem querer' (cf. o verbo transitivo ch'am-s 'comer') }\end{array}$ \\
\hline $\begin{array}{l}\text { shemo-a-k'vd-eb-a 'matar alguém sem intenção' (cf. o verbo transitivo mo-k'l-av } \\
\text { 'matar') }\end{array}$ \\
\hline $\begin{array}{l}\text { shemo-e-mt'vr-ev-a 'quebrar/despedaçar alguma coisa sem intenção' (cf. da- } a \text { - } \\
m t \text { 'vr-ev 'quebrar, despedaçar') }\end{array}$ \\
\hline $\begin{array}{l}\text { shemo-e-xarj-eb-a 'gastar alguma coisa (e.g. dinheiro) sem intenção' (cf. da-xarj- } \\
a v \text { 'gastar') }\end{array}$ \\
\hline $\begin{array}{l}\text { shemo-e-landzgh-eb-a 'ofender alguém sem intenção' (cf. ga-landzgh-av } \\
\text { 'ofender') }\end{array}$ \\
\hline shemo-a-t'q'd'-eb-a 'quebrar sem ter intenção' (cf. ga-t'ex 'quebrar') \\
\hline shemo-e-lax-eb-a 'bater em alguém sem ter intenção' (cf. ga-lax- $a v$ 'bater') \\
\hline
\end{tabular}

Tabela 17: Verbos codificando eventos não volitivos

A seguir, alguns exemplos de sentenças com os verbos listados acima (alguns com diferentes preverbos, mas com a nuance não volitiva preservada), retirados de Asatiani (1998). Atente para o contraste semântico entre as formas marcadas através da construção dativa (com o caso dativo e afixos de concordância B) e aquelas marcadas mais canonicamente:

$\begin{array}{llll}\text { ch'ika } & \text { k'i } & \text { ar } & \text { ga-v-t'ex-e, } \\ \text { vidro.NOM } & \text { apenas } & \text { não } & \text { PV-1AERG-quebrar-AOR } \\ \text { ucabedad } & \text { ga-m-i-t'qd-a } & \\ \text { de repente } & \text { PV-1BDAT-VPR-quebrar-3ANOM.AOR }\end{array}$

Eu não apenas quebrei o vidro, eu (dat.) de repente o quebrei (sem querer).
(131) k'i ar she-v-cham-e,
apenas não PV-1AERG-quebrar- AOR
shemo-m-e-cham-a
PV-1BDAT-VPR-comer-3ANOM.AOR

Eu não apenas comi, eu comi sem ter intenção, sem querer. 
(132) k'i ar ga-v-lax-e, shemo-m-e-lax-a

apenas não PV-1AERG-bater-AOR PV-1BDAT-VPR-bater-3ANOM.AOR

Eu não apenas bati, eu (dat.) bati nele sem ter intenção.

(133) a. dzalian bevri pul-i da-m-e-xarj-a muito muito dinheiro-NOM PV-1BDAT-VPR-gastar-3ANOM.AOR Eu fiquei sem dinheiro (apesar de minha vontade, eu não tive intenção).

b. bevri pul-i da-v-Xarj-e muito dinheiro-NOM PV-1AERG-gastar-AOR Eu gastei muito dinheiro.

(134)

a. bavshv-s v-a-seirn-eb-di da criança-DAT 1ANOM.SG-VPR-levar.para.passear-ST-SM e c'a-m-e-kc-a PV-1BDAT-VPR-cair-3ANOM.AOR

Eu levei a criança para passear e a deixei cair (de forma inesperada, apesar de minha vontade).

b. chemi brali-a, bavshv-i me c'a-v-a-kci-e minha culpa-COP criança-NOM 1 SG.ERG PV-1AERG-VPR-cair-AOR É minha culpa, eu derrubei a criança.

(135) a. me shemo-m-a-k'vd-a

1SG.DAT PV-1BDAT-VPR-matar-3ANOM.AOR

Eu matei (aconteceu, eu não tive intenção).

b. me mo-v-k'al-i

1SG.NOM PV-1ANOM-matar-1ANOM.AOR

Eu matei (eu planejei e matei). 
(136)

a. me c'amo-m-cd-a

1SG.DAT PV-1BDAT.SG-dizer-3ANOM.AOR

Eu disse (eu não queria dizer, escapou).

b. me v-tkv-i

1SG.NOM 1ANOM.SG-dizer-1ANOM.AOR

Eu disse (eu tinha uma razão para dizer algo).

(137)

a. mas a-e-ri-a saxel-eb-i

3SG.DAT PV-VPR-confundir-3ANOM.AOR nome-PL-NOM

Ele confundiu os nomes (mas não tinha a intenção).

b. man a-u-ri-a saxel-eb-i

3SG.ERG PV-VPR-confundir-3ANOM.AOR nome-PL-NOM

Ele confundiu os nomes (intencionalmente).

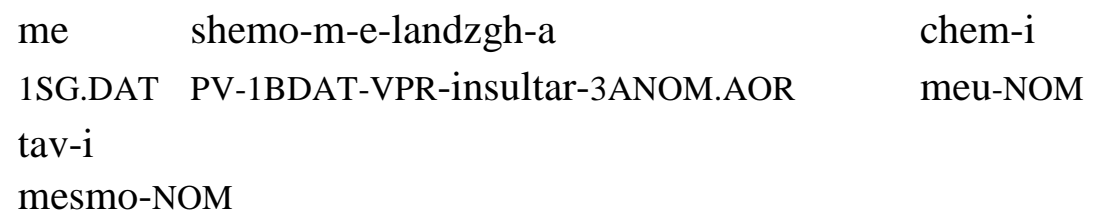

Eu insultei a mim mesmo sem intenção. (AMIRIDZE, 2006, p.56)

Observe que os verbos exemplificados acima são mais usualmente conceitualizados como eventos mais volitivos como 'quebrar', 'comer', 'insultar', 'dizer', etc. Dessa forma, a construção dativa marca uma mudança de significado, tornando-os em eventos menos volitivos e mais marcados semanticamente.

É importante, nesse momento, salientar a importância da vogal pré-radical - $e$ - na formação desses verbos e em verbos experienciais no geral em georgiano.

Como foi mencionado na seção sobre as vogais pré-radicais, a vogal pré-radical - $e$ - serve para adicionar um argumento extra a verbos intransitivos. Em (139a), por exemplo, há um verbo passivo de morfologia de Classe II formado com a vogal préradical - $i$-, nesse caso, a vogal sinaliza que não há nenhum argumento extra adicionado à estrutura verbal. Já em (139b), a troca pela vogal pré-radical -e-indica a adição de um 
segundo nominal que pode adquirir diferentes funções a depender do contexto, como beneficiário ou locativo (como 139b), ou mesmo alvo (140):

a. i-c'er-eb-a

VPR-escrever-ST-3ANOM

Isso foi escrito.

b. e-c'er-eb-a

PV-escrever-ST-3ANOM 3SG.DAT

Isso foi escrito para ele/nele.

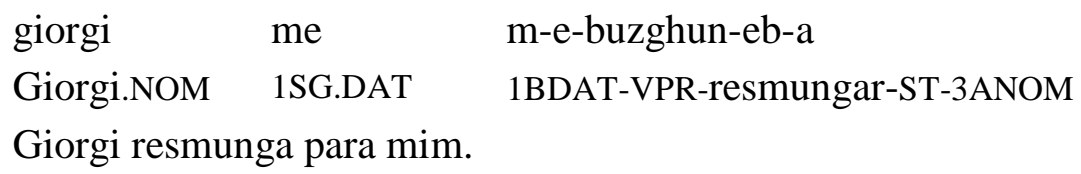

Além da função como versão (ou aplicativa) acima, a vogal pré-radical - $e$ também está presente na formação de certos tempos verbais. O futuro de verbos de Classe IV, por exemplo, é formado por meio da mesma estrutura acima $h$-shia $>e$-shi$e b-a$ 'terá fome', o mesmo acontece com o aoristo desses verbos (quando usado): $s$ dzin- $a v-s>e-d z$ in- $a$. $^{133}$

Observe ainda que a estrutura com a vogal pré-radical - $e$-, indicando a presença do nominal dativo e originalmente intransitiva com somente um argumento, muito se assemelha à estrutura de alguns verbos indiretos no tempo presente, tais como $e$-nat' $r$ $e b-a$ 'sentir falta', $e$-rid-eb- $a$ 'sentir-se tímido'.

Não acreditamos ser coincidência o fato de tantos verbos com a estrutura $-e$ ...eb- apresentarem uma leitura experiencial em que o dativo é o participante mais saliente, à semelhança de verbos psíquicos básicos como $u$-qvar-s 'amar'.

De fato, não somente os verbos experienciais, desiderativos e de julgamento vistos aqui apresentam essa estrutura, mas uma breve verificação nas entradas com a letra 'e', em que há parte das raízes precedidas da vogal pré-radical -e-em dicionários

133 De acordo com a literatura (cf. TUITE, 2007), as formas do futuro e do aoristo de verbos atélicos (normalmente aqueles de morfologia de Classe III e IV) são um desenvolvimento recente na língua e consistem em empréstimos de outras formas verbais, em particular, aqueles de Classe II. 
como Rayfield et al (2006), é suficiente para atestar a pervasividade de significados traduzidos como tendo o nominal dativo como participante mais saliente, carregando algum sentido experiencial, de posse, de não volicionalidade ou não intencionalidade.

À guisa de exemplo, em uma página aleatória da letra 'e' como a p.634 do referido dicionário, das 28 entradas lexicais verbais que lá constam, de maneira sucinta sem nos aprofundarmos, um pouco mais da metade faz referência ao nominal dativo como alvo (16), o restante é composto por experienciadores (8) e possuidores (4). ${ }^{134}$

Essa observação mostra uma relação próxima entre construções com dativos como alvos (e mesmo beneficiários) e construções com o dativo, tanto no papel de experienciador quanto possuidor, construído como foco primário, havendo uma mudança de perspectiva. Mais uma vez, aponta-se para uma conceitualização próxima de experienciadores como locais, favorecendo uma mudança de foco em que, de locais como alvos para onde a ação é dirigida, esse experienciador torna-se o local de onde o evento surge.

Vimos, através dos exemplos anteriores, que há eventos mais volitivos (marcados através de uma morfologia mais típica de Classe I, como o caso ergativo no aoristo) que recebem uma interpretação menos volitiva quando marcados através da construção indireta (sendo comum sua codificação por meio da vogal pré-radical - $e$-, que indicaria a presença do nominal dativo).

Há, ainda, verbos que podem receber leituras diferentes sinalizadas principalmente por padrões de concordância distintos, especialmente verbos de morfologia de Classe II em que a estrutura $-e-\ldots e b$ - é comum. Observe os exemplos a seguir:
a. mepe
e-chven-eb-a
xalx-s
rei.NOM
VPR-aparecer-ST-3ANOM
pessoa-DAT
O rei se mostra para as pessoas. (TSCHENKELI, 1958)

\footnotetext{
${ }^{134} \mathrm{Um}$ exemplo de nominal dativo tido como alvo é a entrada de e-dudghn-eb-a 'falar com alguém (dat.) em uma voz nasal, resmungar para alguém (dat.)'; já exemplos de entradas com experienciadores: $e$ dgm-eb-a 'alguém (dat.) consegue nova força, coragem/é tomado por alegria'; e-ech'v-eb-a 'parece duvidoso a alguém (dat.)'; e-duel-eb-a 'alguém (dat.) está no humor de lutar um duelo'; e exemplos de possuidores: e-grix-eb-a 'a face de alguém (dat.) se contorce'.
} 


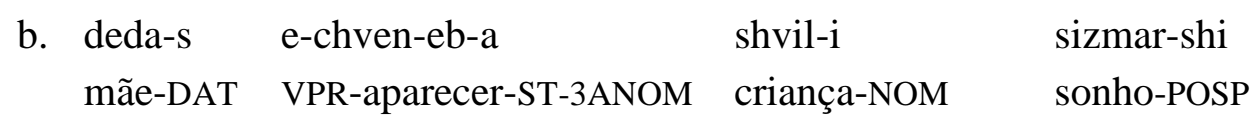
A criança aparece para a mãe no sonho. (A mãe vê a criança aparecendo) (TSCHENKELI, 1958)

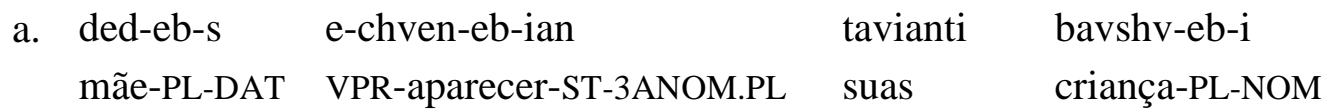
As crianças apareceram diante de suas mães. (TUITE, 1998)

b. ded-eb-s e-chven-eb-a-t tavianti bavshv-eb-i mãe-PL-DAT VPR-aparecer-ST-3ANOM-PL suas criança-PL-NOM As crianças apareceram para suas mães (em sonho). (TUITE, 1998)

Observe que a diferença é sutil entre os exemplos em (a) e aqueles em (b) e a depender da situação, sem o contexto, seriam ambíguas. Dessa forma, exceto pelo contexto e pela concordância no verbo, que aparece apenas quando o sujeito está no plural, não há diferenças estruturais mais marcantes entre eles.

A importância da diferença de concordância de plural, no verbo, será discutida mais detalhadamente na próxima seção. Neste momento, basta notar que, embora em georgiano possa haver concordância com mais de um nominal na sentença (sujeito, objeto direto ou objeto indireto ou mesmo com os três), há uma competição pelos slots de concordância, isto é, em alguns momentos um morfema de concordância leva a preferência para ocupar um dos slots possíveis de concordância no verbo.

Nos casos acima, o que acontece é que, a depender da leitura, o morfema que leva a preferência pode ser aquele que concorda com o nominal no plural no dativo ou no nominativo, já que há morfemas diferenciados no georgiano moderno para cada um (no caso especialmente de morfologia de Classe II), o que não acontece no singular.

O morfema $-t$ é particularmente híbrido, como pode ser notado pela discussão prévia sobre a gramática da língua, ou seja, ele não está associado especificamente a uma pessoa gramatical. Assim, como marca de plural, ele pode acompanhar diversos morfemas, pluralizando-os. Nos casos acima, sua função está ligada à marcação de plural do nominal dativo. 
Nos exemplos em (a), a construção é direta, i.e., a concordância, quando visível, recai sobre o nominal nominativo e este tem uma maior tendência de aparecer em posição inicial na sentença. A interpretação é mais volitiva ou neutra, em que o participante nominativo aparece ou se mostra para o participante no dativo, o alvo.

Já nos exemplos em (b), a construção é indireta, adicionando uma nuance de significação mais experiencial ao evento, já que o significado é de que o participante no dativo vê em sonho a aparição do outro participante.

Em russo, caso similar é encontrado em que o uso do dativo adiciona uma interpretação diferente do evento narrado. De acordo com Janda (1993, p.12), no pirmeiro exemplo com o nominativo, há uma afirmação neutra, já no segundo, com o dativo, o significado é de que a visão é imaginada ou fantasiada:

a. on videl èkzoticheskie goroda ele.NOM ver.PAST exótico cidade.PL.ACC Ele viu cidades exóticas.

b. emu videlis' èkzoticheskie goroda ele.DAT ver.PAST exótico cidade.PL.NOM Ele viu cidades exóticas (em seus sonhos).

Em georgiano, outros exemplos que mostram uma nuance de significado experiencial com a marcação dativa são:

(144) a. damsheul dzaghl-eb-s mgl-eb-i e-c-nen famintos cão-PL-DAT lobo-PL-NOM VPR-cair-3ANOM.PL Os lobos caíram sobre os cães famintos. (TUITE, 1998)

b. damsheul dzaghl-eb-s mgl-eb-i e-c-a-t famintos cão-PL-DAT lobo-PL-NOM VPR-cair-3ANOM-PL Os cães famintos sentiram o odor (Lit.: O odor caiu sobre os cães) (TUITE, 1998) 


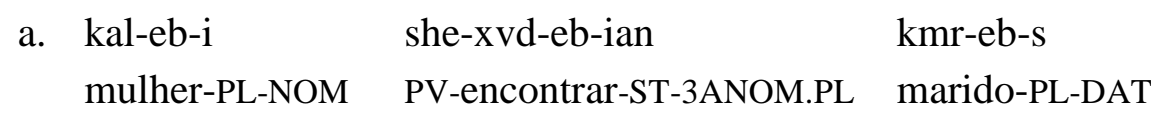
As mulheres encontrarão os maridos. (TUITE, 1998)

b. kal-eb-i she-xvd-eb-a-t kmr-eb-s

mulher-PL-NOM PV-encontrar-ST-3ANOM-PL marido-PL-DAT

Os maridos encontrarão as mulheres (por acaso). (TUITE, 1998)

Novamente, as duas versões em (b) mostram uma nuance de significado experiencial, estruturalmente, observa-se a diferença nos padrões de concordância, sendo que, na construção indireta, é o nominal dativo no plural que concorda com o verbo. Em (144a), o verbo 'cair' está no sentido metafórico de atacar os cães, 'cair sobre'; em (144b), no entanto, o sentido acarretado pela construção indireta é experiencial, os cães sentiram o cheiro do odor, literalmente, o odor caiu sobre os cães.

Em (145a), a sentença no futuro implica uma ação intencional ou volitiva, enquanto na versão indireta em (b), a ação é acidental ou não intencional.

Temos até aqui chamado a atenção para a importância da vogal pré-radical - $e$ - e sua relação próxima com a construção dativa e os significados relacionados a ela (por exemplo, de não volicionalidade, etc.). No entanto, é também importante mencionar o papel, principalmente, das vogais pré-radicais $-i$ - e - $u$ - em construções dativas.

Como foi exposto na seção sobre as vogais pré-radicais e suas funções, as vogais pré-radicais $-i$ - e $-u$ - servem para marcar um participante adicional afetado, como beneficiários. A vogal pré-radical - $i$ - é utilizada quando esse argumento é de primeira ou segunda pessoa, e a vogal - $u$ - é usada quando esse argumento é de terceira pessoa.

Interessantemente, quando essa estrutura é 'invertida' em verbos indiretos, essas mesmas vogais acabam por marcar o experienciador no dativo, mantendo-se a oposição entre pessoas gramaticais. Assim, $m-i$-qvar-s 'eu amo ele/ela' tem a vogal pré-radical $-i$ sinalizando a presença do nominal dativo na primeira pessoa, enquanto $u$-qvar-s 'ele/ela ama ele/ela' tem a vogal pré-radical $-u$ - sinalizando a presença do nominal dativo na terceira pessoa.

Essa ‘inversão' mais uma vez aponta para a relação próxima entre construções aplicativas (de versão) com nominais dativos como alvos e beneficiários e, de outro 
lado, sujeitos experienciadores e possuidores. ${ }^{135}$ A ponto de ser difícil dizer que, em verbos indiretos, essas vogais pré-radicais reteriam a mesma função aplicativa. Parecenos, ao contrário, que essas vogais agem mais como uma forma de concordância (juntamente com os afixos B de concordância) já arraigada com o participante dativo.

Se assim for o caso, é mais um indício de que o nominal dativo em construções dativas é saliente o suficiente para que possa atrair mais um privilégio sintático como concordância, apontando possivelmente para sua proeminência como foco primário em georgiano.

Na seção seguinte, veremos em mais detalhes a concordância com o nominal dativo em georgiano e outros privilégios sintáticos do dativo que usualmente são associados a sujeitos na literatura.

\subsection{Mudança sintática em construções dativas na história do georgiano}

$\mathrm{Na}$ literatura linguística sobre as construções psicológicas com experienciadores no dativo, há sempre questionamentos acerca do status do nominal dativo como 'sujeito' ou como 'objeto', direto ou indireto, a definição da noção de 'sujeito' usualmente se pautando em critérios ou testes sintáticos que se acredita serem característicos dessa relação gramatical, como veremos à frente.

Relembrando nossa discussão do capítulo 3, há uma diferenciação na literatura entre construções experienciais com experienciadores na posição de sujeito como 'eu amo ele' e construções com experienciadores na posição de objeto 'ele me assustou'. Enquanto que construções como essas duas, em algumas línguas, são facilmente distinguidas em termos sintáticos pelas análises, as construções experienciais com experienciadores no dativo não são tão facilmente rotuladas, justamente por certa indefinição do papel gramatical do nominal dativo nessas construções e na gramática das línguas.

\footnotetext{
${ }^{135}$ Alguns exemplos de verbos que marcam um possuidor através das vogais pré-radicais - $u$ - e - $i$ - são: $u$ bghver-ia (tvalebi) 'os olhos (nom.) de alguém (dat.) estão olhando raivosos'; u-xel-ia (tvalebi) 'os olhos de alguém estão abertos'; u-xuch'-av-s (tvalebi) 'os olhos de alguém estão fechados'. Note que a mesma oposição de pessoa gramatical se mantém, se o possuidor for de primeira pessoa, por exemplo, a vogal $i$ - é utilizada: $m$-i-xelia tvalebi 'meus olhos estão abertos'.
} 
E esse questionamento do status dessa construção vis-à-vis às construções ObjExp e SubjExp não é uniforme na literatura. De um lado, essas construções são por vezes tratadas como aproximadas a construções SubjExp, através de características como estatividade e mesmo por razões sintáticas, como o fato de que em algumas línguas o experienciador no dativo tem comportamentos gramaticais associados ao sujeito. De outro, essas construções são aproximadas a construções ObjExp, com um sujeito como estímulo, e o experienciador sendo tratado como um objeto (afetado, de acordo com algumas análises, ou oblíquo e não afetado, de acordo com outras).

Essa aparente ambiguidade, enquanto problemática para algumas teorias, é, acreditamos, bastante reveladora quanto à forma como eventos experienciais são conceitualizados pelas línguas e será importante na discussão no capítulo 7.

Faremos, nesta seção, uma revisão de algumas características observadas na literatura sobre o comportamento sintático do nominal dativo nas línguas e, ao final, do georgiano. Em particular, sob uma perspectiva diacrônica acerca das mudanças documentadas que ocorreram do georgiano antigo ao georgiano moderno.

Como temos visto até aqui, as construções dativas codificando eventos psicológicos e físicos são frequentemente encontradas nas línguas apresentando o argumento experienciador com uma marcação de caso não canônica, i.e., esses argumentos não são nem marcados pelo caso que usualmente marca o sujeito nessas línguas, nem pelo caso que marca o objeto. Dentre esses casos não canônicos, o dativo é particularmente frequente, como no caso do próprio georgiano (em (146)), e de outras línguas de diferentes grupos linguísticos como o malaiala (em (147)), uma língua dravídica:

$$
\begin{array}{llll}
\text { a. } & \text { bich'-eb-s } & \text { u-qvar-t } & \text { gogona } \\
\text { garoto-PL-DAT } & \text { VPR-amar-PL } & \text { menina.NOM } \\
\text { Os garotos amam a menina. } &
\end{array}
$$
b. rat'om s-dzul-t adamian-eb-s ertmanet-i por que 3BDAT-amar-PL pessoa-PL-DAT um.ao.outro-NOM Por que as pessoas odeiam umas às outras?




\begin{tabular}{|c|c|c|c|c|}
\hline \multirow{2}{*}{\multicolumn{2}{|c|}{ (147) a. }} & $\begin{array}{l}\text { kuttik'k'a } \\
\text { criança.DAT }\end{array}$ & $\begin{array}{l}\text { santooSam } \\
\text { felicidade.NOM }\end{array}$ & \multirow[t]{2}{*}{$\begin{array}{l}\text { toonni } \\
\text { sentir.PAST }\end{array}$} \\
\hline & & A criança se & ntiu feliz. & \\
\hline & b. & $\begin{array}{l}\text { kuttik'k'a } \\
\text { criança.DAT }\end{array}$ & $\begin{array}{l}\text { tanuttu } \\
\text { estar.frio.PAST }\end{array}$ & \\
\hline
\end{tabular}

MOHANAN \& MOHANAN (1990).

Além do dativo, outros casos não canônicos de sujeito, como o genitivo e acusativo, são também encontrados, por exemplo, em bengali e islandês respectivamente (ONISHI, 2001).

$\mathrm{O}$ primeiro desafio enfrentado ao se tentar caracterizar o argumento experienciador marcado não canonicamente, especialmente no caso estudado, o dativo, é sua definição como 'sujeito' ou não, principalmente no que se refere às suas características sintáticas.

$\mathrm{Na}$ literatura linguística, o status desse argumento experienciador como sujeito é, como dito, controverso, já que as explicações teóricas diferem acerca da própria definição da noção de sujeito e dos testes em cada língua que funcionariam como diagnóstico dessa noção e que serviriam para desambiguar o status do argumento experienciador nessas construções. Além do mais, como será visto, mesmo entre os testes sintáticos comumente propostos, o argumento experienciador mostra um comportamento nem sempre uniforme, passando em alguns testes e em outros não.

As propriedades usualmente atribuídas a sujeitos são divididas em propriedades de codificação e de comportamento. As primeiras se referem à marcação de caso, concordância e ordem de palavras, já as últimas englobam propriedades sintáticas como imperativos, reflexivização, relativização, subordinação, coordenação, etc. (ONISHI, 2001; NIZAR, 2010, TUITE, 1998).

Cole et al. (1980) têm um estudo conhecido no qual é argumentado, com base nos casos do georgiano e outras línguas, que as propriedades ditas comportamentais seriam adquiridas antes das propriedades de codificação como concordância e caso. $\mathrm{O}$ georgiano, de acordo com o estudo, representaria um dos últimos estágios, em que o argumento já teria adquirido concordância, mas não ainda caso (nominativo, no caso). 
$\mathrm{Na}$ literatura linguística do georgiano, o argumento experienciador é frequentemente referido como o sujeito 'lógico' ou semântico. Tuite (1998), ao rever algumas propriedades que seriam pertinentes no georgiano como diagnósticas do sujeito como imperativos e o comportamento do reflexivo tav- e do recíproco ertmanet-, observa que argumentos experienciadores dativos são encontrados nas formas do imperativo (em (148)) e na posição de sujeito, servindo como antecedente a esses pronomes (compare os exemplos em (149), e observe os exemplos em (150)):
a. ag-s-deg,
gmirt-gmir-o
$\mathrm{nu}$
g-dzinav-s
PV-2A-levantar
herói.GEN.PL-herói-VOC não
2BDAT-dormir-3ANOM
Levanta-te, herói dos heróis, não durma! [A. C'ereteli]

(149) a. gv-dzul-s

ertmanet-i

1BDAT.PL-odiar-3ANOM um.ao.outro.NOM

Nós odiamos um ao outro

b. v-s-cem-t ertmanet-s

1ANOM-3BDAT-bater-PL um.ao.outro-DAT

Nós batemos um no outro.

TUITE (1998).
a. giorgi-s
u-qvar-s
tavis-i
tav-i
Giorgi-DAT VPR-amar.3ANOM
3SG.REFL-NOM
si.mesmo-NOM
Giorgi ama a si mesmo.

b. salva-s s-dzul-s

$$
\text { tavis-i }
$$

tav-i

Shalva-DAT 3BDAT-odiar.3ANOM

3SG.REFL-NOM si.mesmo-NOM

Shalva odeia a si mesmo.

c. d-eb-s e-nat'r-eb-a-t

ertmanet-i

irmã-DAT VPR-sentir.falta.ST-3ANOM-PL um.ao.outro-NOM

As irmãs sentem falta uma da outra.

(AMIRIDZE, 2006) 
Testes similares também são utilizados em outras línguas. Em albanês, também é possível notar comportamento similar do nominal dativo em anáforas nos exemplos retirados de Amiridze (2006):
a. vetja
më
dhimset
mesmo.NOM CL.1SG.DAT sentir.muito.3SG.PRES

Eu sinto muito por mim mesmo.
b. dritës i
dhimset
vetja
Drita.DAT CL.3SG.DAT sentir.pena.3SG.PRES
mesmo.NOM

Drita sente pena de si mesma.

No latim, segundo Fedriani (2014, p.41), o sujeito é normalmente definido como aquele marcado com o caso nominativo, que aciona concordância verbal e apresenta uma série de comportamentos sintáticos típicos, tais como reflexivização, redução de conjunção, alçamento a objeto, etc. ${ }^{136}$ No entanto, como a autora discute, essas propriedades não são exclusivas dessa noção de sujeito, sendo encontradas em argumentos não canônicos ou em 'sujeitos lógicos'.

Em construções dativas, o experienciador no dativo, apesar de não acionar concordância, tipicamente antecede o estímulo nominativo na ordem de palavras em sentenças declarativas, assim como acontece em georgiano:

$\begin{array}{llllll}\text { (152) } & \text { mihi } & \text { caligae } & \text { eius } & \text { et fasciae } & \text { cretatae } \\ \text { 1SG.DAT } & \text { botas.NOM.PL } & \text { 3SG.GEN } & \text { e } & \text { calças.NOM.PL branca.NOM.PL } \\ \text { non } & \text { placebant } & & & \\ \text { não } & \text { agradar.IMPF.3PL } & & \end{array}$

Suas botas e calças brancas não me agradam.

\footnotetext{
${ }^{136}$ Foi mantida a nomenclatura usada pela autora. Redução de conjunção é uma regra advinda da gramática gerativa que se refere a casos de elipse em coordenadas, isto é, quando alguma parte comum entre duas sentenças coordenadas é codificada na primeira mas omitida na segunda. Já 'alçamento a objeto', termo também advindo da gramática gerativa, é usado para se referir a casos como 'João esperou Maria sair' em que o sujeito do verbo 'sair' no infinitivo é correferencial com o objeto do verbo finito 'esperar'.
} 
(FEDRIANI, 2014)

Em (152), o pronome dativo mihi precede o estímulo nominativo que, por sua vez, aciona concordância plural no verbo.

Além do mais, o experienciador no dativo exibe na língua certas propriedades sintáticas de sujeito mencionadas acima, como redução de conjunção (em (154)), alçamento a objeto e reflexivização de longa distância (em (153)):

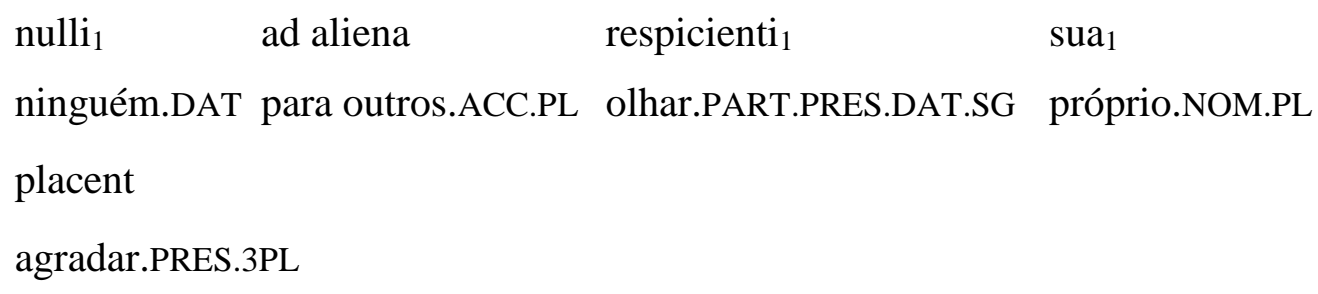

$$
\begin{aligned}
& \text { scio } \quad \varnothing_{\mathrm{i}} \text { quid dictura es: } \text { hanc }_{\mathrm{j}} \text { esse } \\
& \text { saber.PRES.1SG o que dizer.PART.FUT.2SG DEM.ACC.SG ser.INF.PRES } \\
& \text { pauperem. } \varnothing_{\mathrm{i}} \operatorname{haec}_{\mathrm{j}} \quad \text { pauper }_{\mathrm{j}} \quad \text { placet } \\
& \text { pobre.ACC.SG DEM.NOM.SG pobre.NOM.SG agradar.PRES.3SG }
\end{aligned}
$$

Eu sei o que você vai dizer: ela é pobre. Mas eu gosto dessa pobre mulher. (FEDRIANI, 2014, p. 98).

Em línguas leste-caucasianas como tsakhur, Comrie e van den Berg (2006) notam comportamento similar, ao observado acima, do dativo em construções experienciais.

Em tsakhur, em sentenças intransitivas é usualmente o absolutivo que controla anáforas, enquanto em sentenças transitivas é o argumento ergativo que controla. Em construções experienciais com o dativo, no entanto, é o experienciador no caso dativo que obrigatoriamente controla a anáfora que permanece no caso absolutivo, observe: 


$$
\begin{array}{llll}
\text { rasul-u-s } \quad \text { dzhu-s } & \text { wudzh } & \text { ikkan } \\
\text { Rasul-OBL-DAT REFL.1SG.OBL-DAT } & \text { REFL.1SG.ABS } & \text { amar.1SG.IMPF }
\end{array}
$$

Rasul ama a si mesmo. (COMRIE \& van den BERG, 2006, p. 140)

Em outras línguas leste-caucasianas como bagvalal, embora haja outras opções de ligação de anáforas de acordo com fatores como ordem de palavras, há uma preferência de que o agente (ergativo), antes que o paciente, controle a anáfora em sentenças transitivas; e de que o experienciador, antes que o estímulo, controle a anáfora em construções experienciais (COMRIE \& van den BERG, 2006).

Já em outras línguas como tsez, quando há correferência entre estímulo e experienciador, é usado um padrão em que é o argumento absolutivo que controla a anáfora, que permanece no caso dativo. Interessantemente, na mesma língua, em casos de omissão de sintagmas correferenciais em sentenças adjacentes, tanto o único argumento de intransitivas, quanto o sujeito de transitivas e o experienciador em construções experienciais, comportam-se da mesma forma. A omissão desses argumentos é obrigatória quando o antecedente na sentença principal for qualquer um desses três argumentos. Já quando o antecedente for um objeto de transitiva ou um estímulo em construções experienciais, a omissão é opcional, indicando que esses dois argumentos se comportam da mesma forma nesses casos.

No exemplo abaixo, o experienciador no caso dativo é o antecedente na sentença principal e é obrigatoriamente omitido na sentença adjacente:

$$
\begin{array}{lllll}
\text { “ali-r } & \text { aho } & \text { [guz } & \text { p'oLi-r-L'orey }] & \text { esu-s } \\
\text { Ali-DAT } & \text { pastor.ABS } & \text { pedra.ABS } & \text { explodir-CAUS-DUR } & \text { achar.PAST }
\end{array}
$$

Enquanto explodia a pedra, Ali achou (deparou-se com) um pastor de ovelhas. (COMRIE \& van den BERG, 2006, p. 144)

Indo além, para as línguas dravídicas, em malaiala, por exemplo, Nizar (2010) revê na língua testes sintáticos que poderiam ou não indicar que o argumento experienciador no dativo seria, de fato, um sujeito sintático. $\mathrm{O}$ autor começa mostrando que o comportamento do argumento experienciador é ambíguo, comportando-se ora 
como sujeito (como em testes de causativização, redução de conjunção e controle) ${ }^{137}$, ora como um objeto indireto de acordo com algumas análises.

Tendo em vista esse comportamento, Nizar (2010) contrapõe análises que advogam a favor de tratar esse argumento como sujeito (como a análise de Mohanan \& Mohanan (1990)) ou como um objeto indireto (a análise de Jayaseelan (2004)). O autor, no entanto, refuta os argumentos de Jayaseelan (2004), trazendo dados, segundo Nizar, não considerados e propondo que em malaiala o argumento experienciador dativo teria comportamento sintático compatível com o de um sujeito.

Por exemplo, Jayaseelan (2004 apud Nizar (2010)), argumenta que uma construção de controle em que o argumento dativo seria PRO na oração subordinada infinitiva, sendo esse um diagnóstico de sujeito válido, não seria uma sentença possível, pois o sujeito necessariamente teria que ser agentivo, o que não é o caso do argumento experienciador que não possui volicionalidade.

Nizar (2010) mostra, no entanto, que essa sentença seria sim possível, como com o verbo sramikkuka 'tentar'.

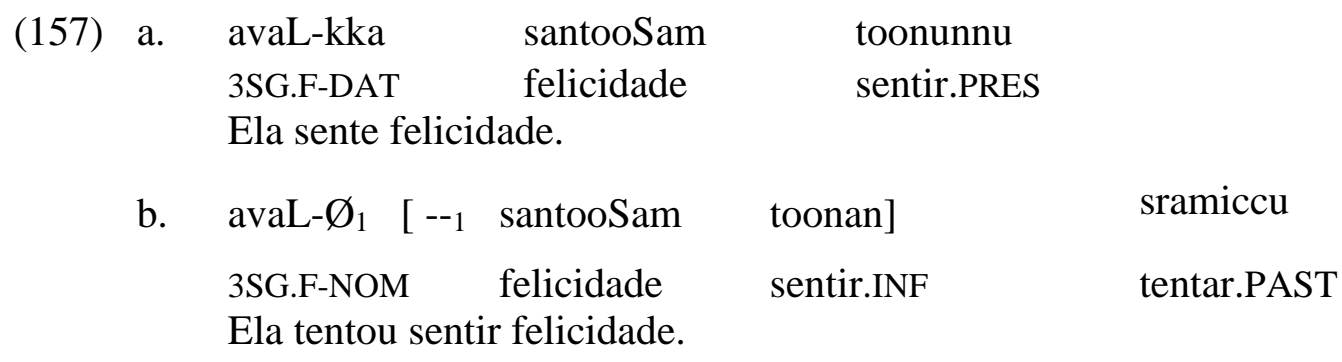

(NIZAR, 2010)

Em (157b), o argumento da oração principal é correferencial com o argumento dativo experienciador omitido na oração subordinada infinitiva. Segundo Nizar (2010), o que permite ser gramatical a sentença em (157b) é a possibilidade de algumas construções com sujeito experienciador dativo serem construídas com certo grau de volição. No caso desse exemplo, para o autor, esse grau de volição do experienciador seria devido ao maior grau de volição do sujeito correferencial que o controla na sentença principal.

\footnotetext{
${ }^{137}$ Foi mantida a nomenclatura utilizada pelo autor, cf. nota 134 e o exemplo em (157).
} 
Assim como no georgiano, em malaiala, o argumento experienciador dativo também pode servir como antecedente a anáforas (cf. exemplo em (158)), como com o reflexivo taan.

$$
\begin{array}{lllll}
\text { avaL-kka }_{1} & \tan ^{2} \mathrm{re}_{1} & \text { kuTTi-kal-e } & \text { iFTam } & \text { aaNa } \\
\text { 3SG.FEM-DAT } & \text { REFL-GEN } & \text { criança-PL-ACC } & \text { gostando } & \text { estar.PRES }
\end{array}
$$
Ela $_{1}$ gosta de suas 1 crianças.

(NIZAR, 2010)

Embora a argumentação de Nizar (2010) gire, principalmente, em torno de propriedades comportamentais das construções dativas, o autor faz alguns breves comentários acerca das suas propriedades de codificação. ${ }^{138}$

Em relação à ordem de palavras, o malaiala apresenta algumas similaridades com o georgiano. Ambos possuem uma ordem de palavras mais livre. No entanto, o argumento experienciador dativo tem uma maior predisposição a aparecer na posição inicial das sentenças em comparação ao estímulo nas duas línguas.

Diferente do georgiano que possui um complexo sistema de concordância verbal, o malaiala perdeu suas formas de concordância. Em outras línguas dravídicas em que o sistema de concordância se manteve, como em tâmil e em kannada, a concordância é feita com o argumento nominativo (NIZAR, 2010).

De fato, o que se observa nas línguas, em que há a construção dativa com verbos experienciais, é a concordância com o estímulo (como o russo e espanhol abaixo) ou uma concordância sem referente aparentemente codificado, assemelhando-se a construções impessoais (como a construção me pudet do latim ou mesmo construções adjetivais dativas do russo mne ploxo 'eu me sinto bem').

\footnotetext{
$138 \mathrm{O}$ autor, seguindo o estudo de Cole et al. (1980) mencionado acima, assume que as propriedades comportamentais seriam adquiridas antes das propriedades de codificação, como as de caso, concordância e ordem de palavras já mencionadas.
} 

a. me
gustan
las
manzanas
1SG.DAT
gostar.3PL
as
maçã.PL

Eu gosto de maçãs.

b. mne nravit'sya eta kniga

1SG.DAT gostar.3SG esse livro.NOM

Eu gosto desse livro.

Situação, no entanto, diferente se apresenta no georgiano. Atualmente na língua, há uma forte preferência a concordar com o argumento dativo (cf. CHERCHI, 1997; TUITE, 1998). Observe o exemplo em (146) e (160) abaixo, em que o argumento dativo plural concorda com o verbo através do sufixo - $t$.

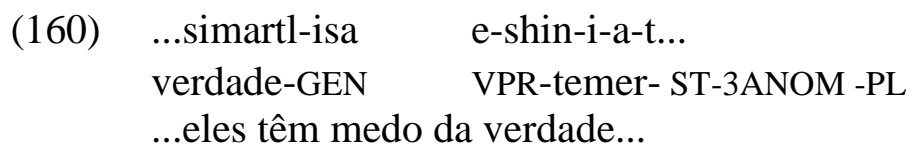

(CHERCHI, 1997)

Essa tendência a concordar com o argumento dativo é um desenvolvimento relativamente recente na história da língua. De acordo com o estudo de Tuite (1998), que investigou a concordância de número em georgiano desde os primeiros manuscritos encontrados em georgiano antigo, datados do século $\mathrm{V}$, a preferência era de concordância de número com o argumento nominativo e não com o argumento experienciador dativo como no georgiano moderno.

Os exemplos abaixo pertencem ao primeiro período divisado pelo autor, do século V a VII, e ilustra a concordância com o argumento plural nominativo vista nos exemplos através do afixo -nes em (161a) e do afixo -en em (161b): 


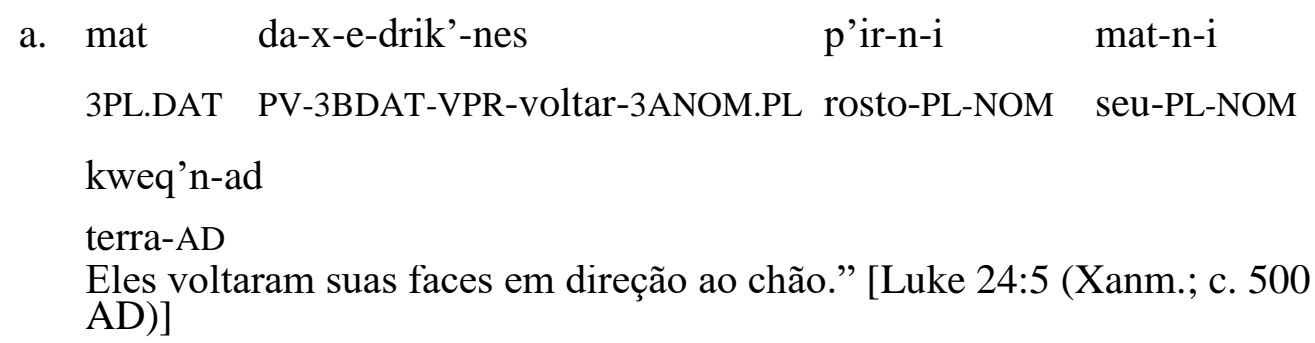

a. mat da-X-e-drik'-nes p'ir-n-i mat-n-i

3PL.DAT PV-3BDAT-VPR-voltar-3ANOM.PL rosto-PL-NOM seu-PL-NOM

kweq'n-ad

terra-AD

Eles voltaram suas faces em direção ao chão.” [Luke 24:5 (Xanm.; c. 500 $\mathrm{AD})]$

b. uk'wetu g-i-q'war-den tkwen moq'ware-n-i

se 2BDAT-VPR-amar-3ANOM.PL 2PL.DAT amante-PL-NOM

tkwen-n-i

seu-PL-NOM

Se vocês amarem aqueles que os amam... [Luke 6:32 (Xanm.)]

(TUITE, 1998)

Em (161a), -nes concorda com o argumento nominativo na terceira pessoa do plural p'irni matni; no georgiano moderno, a forma verbal seria da-e-drik'-a-t, o sufixo - $t$ concordando com a terceira pessoa do plural no dativo mat. Em (161b), o sufixo -en concorda com a terceira pessoa plural no nominativo moq'wareni tkweni; no georgiano moderno, a forma verbal seria $g-i-q$ 'var- $d-e-t$, o sufixo $-t$ marcaria a pluralidade da segunda pessoa $(g-)$ do argumento dativo tkwen.

No georgiano antigo, a marca de plural - $t$ era apenas usada para marcar a pluralidade da primeira e segunda pessoa quando no nominativo, $x-w-u-q$ 'war- $t$ 'ele/eles (dat.) nos (nom.) amam' e $x$ - $u-q$ 'war-t 'ele/eles (dat.) amam vocês (nom.)'.

Esse padrão de concordância se manteve no período subsequente do georgiano antigo clássico, século VIII a XI. Como nota Tuite (1998), apesar de o argumento experienciador (assim como o dativo em casos de inversão) já exibir no georgiano antigo propriedades sintáticas iguais ao georgiano moderno, como ligação de anáforas, controle e ordem de palavras similar, o argumento dativo ainda era incapaz de acionar concordância de número no verbo. O exemplo a seguir ilustra o argumento dativo como o argumento em posição inicial e, ao mesmo tempo, seu papel como antecessor à anáfora: 


$$
\begin{array}{llll}
\text { martal-ta tana } & \text { she-e-racx-a } & \text { tav-i } & \text { twisi } \\
\text { virtuoso-DAT.PL com } & \text { PV-VPR-considerar-3ANOM } & \text { REFL-NOM } & \text { seu-NOM } \\
\text { Ele considera a si mesmo como um dos virtuosos. } &
\end{array}
$$

(TUITE, 1998)

No período do georgiano médio, século XII a XIII, os primeiros sinais de uma mudança nos padrões de concordância podem ser observados (TUITE, 1998). O sufixo $t$ que antes marcava apenas a pluralidade de primeira e segunda pessoa no nominativo, passa a aparecer marcando a pluralidade do argumento dativo (tanto na segunda quanto na terceira pessoa).

Segundo o autor, os primeiros verbos atestados eram aqueles com argumentos dativos associados a experienciadores ou que tinham papel agentivo (no caso, por exemplo, de inversão nas Séries III que denotam evidencialidade). O que mostra, para o autor, que houve uma mudança em relação ao tipo de propriedade do SN mais relevante para a concordância: no georgiano antigo era caso (o nominativo) e o conjunto de marcas de concordância (marcas do conjunto A que normalmente marcavam no verbo o sujeito em tempos verbais sem inversão); no georgiano médio, aspectos como pessoa e papel semântico (e, mais tarde, animacidade) começam a ganhar importância.

No período do georgiano médio tardio, século XIV a XVIII, continuou a haver variabilidade no uso do sufixo de plural $-t$, por vezes dentro do mesmo texto ou mesmo em sentenças adjacentes (TUITE, 1998). Por volta do final do período, a concordância com o argumento dativo torna-se mais frequente do que nos textos mais antigos, indicando provavelmente uma situação de diglossia entre a norma do georgiano antigo e a língua falada (TUITE, 1998).

No período do georgiano moderno, do século XVIII em diante, observa-se a predominância da concordância com argumentos animados plurais no geral e certa variabilidade na concordância com argumentos inanimados, havendo uma tendência maior de não concordância em número quando inanimado.

Em relação à concordância com argumentos dativos, a obrigatoriedade que se via no georgiano antigo com o argumento nominativo (independentemente de sua semântica ou sintaxe) torna-se no georgiano moderno em obrigatoriedade de concordância com o argumento dativo. 
Uma maneira simples de entender a mudança ocorrida no sistema de concordância e sua importância é observar, em primeiro lugar, o padrão de concordância no georgiano atual. A tabela abaixo mostra o paradigma de concordância verbal, com o objeto na terceira pessoa (que não distingue singular de plural), usando como exemplo o verbo xedva 'ver' no presente:

\begin{tabular}{|c|c|}
\hline \multirow{2}{*}{ Sujeito } & Objeto \\
\cline { 2 - 2 } & $3^{\text {a }}$ pessoa \\
\hline 1SG & v-xed-av \\
\hline 1PL & v-xed-av-t \\
\hline 2SG & xed-av \\
\hline 2PL & xed-av-t \\
\hline 3SG & xed-av-s \\
\hline 3PL & xed-av-en \\
\hline
\end{tabular}

Tabela 18: Concordância com objeto de terceira pessoa - Séries I do presente (padrão normal).

Observe que a concordância com o sujeito na terceira pessoa possui uma marca explícita indicando a pessoa e número (-s para o singular e -en para o plural). Já a concordância com o objeto na terceira pessoa não possui uma marca explícita, não sendo possível distinguir uma forma singular de uma plural. A Tabela 19 a seguir mostra o paradigma de inversão no modo evidencial (Séries III) do mesmo verbo xedva (radical nax-).

\begin{tabular}{|c|c|c|}
\hline \multirow{2}{*}{ Objeto } & \multicolumn{2}{|c|}{ Sujeito } \\
\cline { 2 - 3 } & $3^{\text {a }}$ pessoa sg. & $3^{\text {a }}$ pessoa pl. \\
\hline 1SG & \multicolumn{2}{|c|}{ v-u-nax-av-var } \\
\hline 1PL & \multicolumn{2}{|c|}{ v-u-nax-av-var-t } \\
\hline 2SG & \multicolumn{2}{|c|}{ u-nax-av-xar } \\
\hline 2PL & \multicolumn{2}{|c|}{ u-nax-av-xar-t } \\
\hline 3 & u-nax-av-s & u-nax-av-t \\
\hline
\end{tabular}

Tabela 19: Concordância com o sujeito de terceira pessoa (objeto indireto no dativo) - Séries III do evidencial (padrão de inversão).

No georgiano moderno padrão, quando o objeto (no nominativo) é de terceira pessoa, há a distinção de número entre o sujeito (no dativo) de terceira pessoa (sufixo - $t$ 
para o plural). Distinção essa que não é feita quando o argumento no dativo marca o objeto de terceira pessoa no padrão normal (cf. tabela 18).

No georgiano antigo, essa distinção não existia. Na tabela abaixo, mostram-se as modificações nas formas de concordância em verbos de conjugação indireta (raiz q’var 'amar'), note que até o século VIII o prefixo $m$ - era associado à primeira pessoa exclusiva e $g w$ - à primeira pessoa inclusiva (e não, ainda, à oposição de número entre primeira pessoa singular e plural como atualmente):

\begin{tabular}{|c|c|c|c|}
\hline \multirow{2}{*}{$\begin{array}{l}\text { Objeto } \\
\text { (nom.) }\end{array}$} & Sujeito (dat.) & \multirow{2}{*}{$\begin{array}{c}\text { Sujeito } \\
\text { (dat.) }\end{array}$} & Objeto (nom.) \\
\hline & $3^{\mathrm{a}}$ pessoa $\mathrm{SG} / \mathrm{PL}$ & & $3^{\mathrm{a}}$ pessoa $\mathrm{SG}$ \\
\hline $1 \mathrm{SG}$ & X-w-u-q'war & 1 excl. & m-i-q'war-s \\
\hline $2 \mathrm{SG}$ & x-u-q’war & 2SG/PL & g-i-q'war-s \\
\hline $3 \mathrm{SG}$ & x-u-q'war-s & $3 \mathrm{SG} / \mathrm{PL}$ & X-u-q'war-s \\
\hline $1 \mathrm{PL}$ & $\mathrm{x}-\mathrm{w}-\mathrm{u}-\mathrm{q}$ 'war-t & 1incl. & gw-i-q'war-s \\
\hline $2 \mathrm{PL}$ & x-u-q'war-t & & \\
\hline 3PL & x-u-q'war-an & & \\
\hline
\end{tabular}

Tabela 20: Padrões de concordância de verbos indiretos no georgiano antigo (TUITE, 1998).

Observe que a pluralidade do argumento nominativo na primeira coluna (na função de objeto na tabela, por exemplo, $x$ - $u$-q'war-an significa 'ele/eles (dat.) os (nom.) ama/m') sempre é marcada, o que não acontece com o argumento dativo. $\mathrm{Na}$ segunda coluna, é possível observar que a mesma forma de segunda e terceira pessoa é usada tanto para o plural quanto singular, não havendo distinção ou marcação diferente, desse modo, a forma $g-i-q$ 'war-s pode significar tanto 'você (dat.) o (nom.) ama' quanto 'vocês (dat.) o (nom.) amam'.

No georgiano moderno a situação é diferente, na primeira coluna da Tabela 20 é possível perceber que o equivalente à forma $x$ - $u$-q'war-an do georgiano antigo deixou de ser usada, i.e, a pluralidade do argumento nominativo de terceira pessoa em sua função de objeto não é mais diferenciada, assim, $u$-q'var-s significa no georgiano moderno tanto 'ele o ama' quanto 'ele os ama'.

Na segunda coluna, a pluralidade do argumento dativo é sempre marcada, tanto na primeira pessoa do plural gv-i-q'var-s (que no georgiano antigo marcava uma oposição de plural inclusivo versus exclusivo), quanto segunda e terceira pessoa através do sufixo $-t$. 


\begin{tabular}{|c|c|c|c|c|}
\hline \multirow{2}{*}{$\begin{array}{c}\text { Objeto } \\
\text { (nom.) }\end{array}$} & Sujeito (dat.) & & $\begin{array}{c}\text { Sujeito } \\
\text { (dat.) }\end{array}$ & Objeto (nom.) \\
\cline { 2 - 2 } & $3^{\text {a }}$ pessoa SG / PL & & $3^{\text {a }}$ pessoa SG \\
\hline 1SG & v-u-q'var-var & & 1SG & m-i-q'var-s \\
\hline 2SG & u-q'var-xar & & 2SG & g-i-q'var-s \\
\hline 3SG/PL & u-q'var-s & & 3SG & u-q'var-s \\
\hline 1PL & v-u-q'var-var-t & & 1PL & gv-i-q'var-s \\
\hline 2PL & u-q'var-xar-t & & 2PL & g-i-q'var-t \\
\hline & & & 3PL & u-q'var-t \\
\hline
\end{tabular}

Tabela 21: Padrões de concordância de verbos indiretos no georgiano moderno (TUITE, 1998).

É importante notar que, de acordo com a norma padrão, as formas $v-u$-q'var-var$t$ e $u$-q'var-xar-t só poderiam ser marcadas com a pluralidade do argumento dativo plural quando o objeto nominativo é de terceira pessoa, pois a pluralidade do objeto de primeira ou segunda pessoa no nominativo bloquearia a marca de plural do argumento dativo. Dessa forma, v-u-q'var-var e $u-q$ 'var-xar poderiam significar tanto 'ele (dat.) me/te (nom.) ama' quanto 'eles (dat.) me/te (nom.) amam'. Já $v$-u-q'var-var-t e $u-q$ 'varxar-t só podem significar respectivamente 'ele/eles (dat.) nos (nom.) amam' e 'ele/eles (dat.) amam vocês (nom.)' e não 'eles (dat.) me/te (nom.) amam' com o sufixo - $t$ a indicar a pluralidade do argumento dativo (cf. TUITE, 1998; TSCHENKELI, 1958).

No entanto, como é notado por Tuite (1998), Tschenkeli, (1958) e Cherchi (1997), no georgiano coloquial encontram-se frequentemente as formas $v-u-q$ 'var-var-t e $u-q$ 'var-xar-t significando respectivamente 'eles (dat.) me (nom.) amam' e 'eles (dat.) te (nom.) amam', o sufixo - $t$ marcando assim a pluralidade do sujeito dativo. Esse dado é interessante, já que mostra a crescente tendência na língua para marcar no verbo o argumento dativo em verbos indiretos.

Dessa exposição, é importante ainda salientar que, embora o fator de animacidade tenha sido crucial na mudança ocorrida em georgiano, não foi o único, pois a mudança começa a ser atestada, coincidentemente, com verbos experienciais e evidenciais, justamente aqueles que possuem, como Tuite (1998) os chama, 'sujeitos lógicos', apontando para alguma forma de proeminência desses participantes.

Ademais, muitos verbos experienciais de dois argumentos podem apresentar ambos como participantes animados, como é o caso de u-qvar-s 'amar'. Nesse caso, e mesmo nos casos mais raros em que o dativo representa um participante inanimado, a concordância é obrigatória com o argumento dativo na língua. Observe os exemplos de Tuite (1998) abaixo que ilustram um participante inanimado no dativo gerando 
concordância ((163a) e (163b)), por vezes com um participante no nominativo animado (163a):

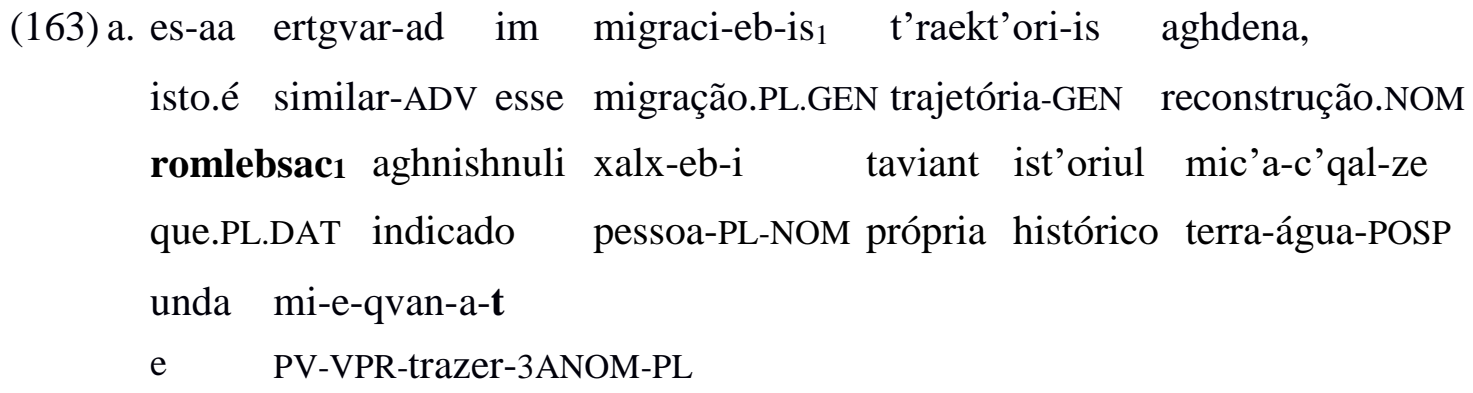

Isto é, similarmente, a reconstrução da trajetória dessas imigrações que devem ter trazido as pessoas indicadas para suas cidades históricas. (TUITE, 1998, p. 127).

b. mesame seri-is nak'vt-eb-s saerto punkcia a-ertian-eb-t terceira séries-GEN forma-PL-DAT comum função.NOM VPR-unir-ST-PL As formas das Séries III são unidas por uma função comum. [Gogolashvili, 1984, p.14]

(TUITE, 1998, p.134)

Um dado interessante é que apenas posteriormente (no final do período do georgiano médio) houve uma extensão dessa mudança de padrão de concordância a outros verbos não volitivos (como aqueles vistos de Classe II) (TUITE, 1998).

No mesmo período, séculos XVII e XVIII, notam-se casos em que a concordância em número ocorre, por vezes, com possuidores, beneficiários e outros objetos indiretos (exemplos a seguir, respectivamente):

$$
\begin{array}{lllll}
\text { (164) }[\ldots] & \text { da } & \text { mashingha } & \text { gan-u-natld-a-t } & \text { tval-eb-i } \\
& \text { e } & \text { então } & \text { PV-VPR-iluminar-3ANOM-PL } & \text { olho-PL-NOM }
\end{array}
$$

[...] e então, seus olhos se iluminaram.

(Adaptado de Tuite (1998, p.114)) 


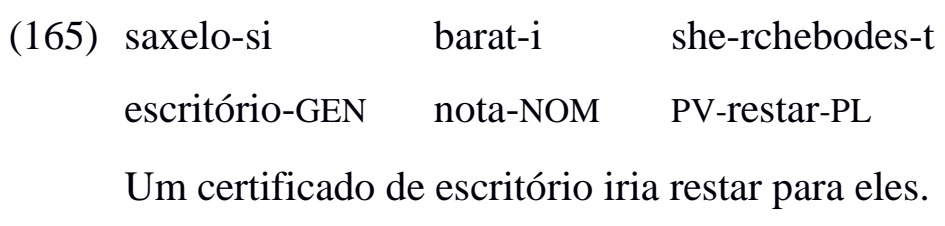

(TUITE, 1998, p.114)

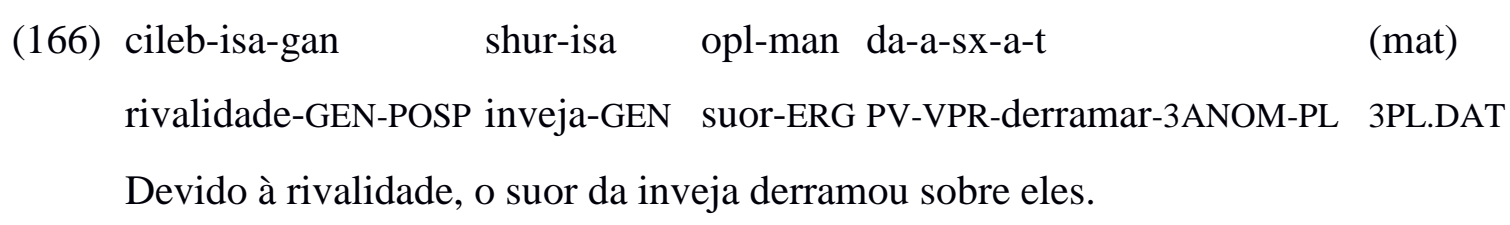

(TUITE, 1998, p.114)

No entanto, como Tuite (1998) comenta, esses casos de concordância não são tão automáticos no georgiano quanto o são com experienciadores e teriam outras motivações mais específicas. Tuite, por exemplo, nota que a concordância nesses casos é preferida quando o nominal dativo é anafórico, isto é, é um participante já citado no texto como nos três casos acima. Dessa forma, a concordância ajudaria a retomar o referente do nominal dativo.

Isso é importante, pois mostra que enquanto a animacidade é um fator que influencia a concordância (inclusive nos casos acima), não é apenas o único fator nem talvez o mais determinante, pois se assim fosse, é bem possível que a mudança nos padrões de concordância e sua posterior obrigatoriedade teria igualmente se espalhado a outros nominais dativos animados na língua, virando a regra também para esses nominais.

\subsection{Evidencialidade}

Discutimos na seção anterior que os casos de inversão juntamente com verbos experienciais foram os primeiros a apresentarem sinais de mudança nos padrões de concordância com o nominal dativo.

Inversão em georgiano, como foi exposto na seção sobre a gramática da língua, ocorre com verbos de morfologia de Classe I e III nas Séries III do perfeito, havendo 
uma inversão na marcação de caso e de afixos de concordância no verbo. Observe as mudanças na tabela abaixo em uma sentença como 'O homem constrói a casa':

\begin{tabular}{|c|c|}
\hline $\begin{array}{c}\text { Verbo de } \\
\text { Classe I }\end{array}$ & a-shen-eb-s 'construir' \\
\hline I - Presente & k'ac-i (nom.) a-shen-eb-s saxl-s (dat.) \\
\hline II - Aoristo & k'ac-ma (erg.) a-a-shen-a saxl-i (nom.) \\
\hline III- Perfeito & k'ac-s (dat.) a-u-shen-eb-ia saxl-i (nom.) \\
\hline \multicolumn{2}{|l}{ Tabela 22: Verbo $a$-shen-eb-s 'construir' nas três Séries }
\end{tabular}

É interessante que essa mudança de morfologia é acompanhada por uma mudança de significado.

Sentenças no perfeito em georgiano são conhecidas por terem um significado evidencial, ou seja, marcam a fonte de informação (se foi visto ou não pelo falante):
(167) mas
sk'am-i
aivan-ze
da-u-dgam-s
3SG.DAT
cadeira-NOM
balcão-POSP
PV-VPR-colocar-3ANOM.SG
Parece que ele colocou a cadeira no balcão.

(GÄUMANN, 2011, p.125)

O evento acima expressa uma situação em que o falante não presenciou ou não viu em primeira mão o acontecimento em que a cadeira foi colocada, por isso, só pode supor que a cadeira tenha sido colocada por determinada pessoa.

Esse uso do passado evidencial contrasta com o aoristo que é neutro quanto à fonte de informação, normalmente implicando que o falante viu o acontecimento:
(168) man
sk'am-i
aivan-ze
da-dg-a
3SG.ERG
cadeira-NOM
balcão-POSP PV-colocar-AOR

Ele colocou a cadeira no balcão.

(GÄUMANN, 2011, p.125)

De acordo com Topadze \& Ramat (2007), evidencialidade em georgiano expressa conhecimento indireto sobre o evento, possivelmente porque o falante não o 
testemunhou, mas obteve informação de fontes indiretas como ter ouvido falar (segunda ou terceira mão), por inferência (ao ver seu resultado) etc. ${ }^{139}$

Advérbios também podem ser usados para dar o sentido de evidencialidade, como o advérbio turme 'aparentemente' que, quando usado com o perfeito reforça seu sentido de evidencialidade (TOPADZE \& RAMAT, 2007).

Segundo Asatiani (1998), há também uma nuance de resultatividade, remanescente das origens resultativas do perfeito em georgiano. Em construções nas Séries III, principalmente nos casos de inferência, haveria uma interpretação de que o falante realiza seu enunciado a partir do resultado da ação, descrevendo ou relatando essa ação tal como 'aparentemente' acha que se deu, já que pode não ter visto ou presenciado a situação em questão, ou por não ter certeza do ocorrido (mesmo, em alguns casos, quando é o agente da ação), ou por não se lembrar ou por não ter prestado suficiente atenção.

Outros significados do perfeito, além de evidencialidade, são iteratividade, miratividade (envolvendo surpresa por parte do falante diante de algo inesperado ou uma nova informação) e sentidos experienciais:
(169)
es pilm-i bevrdzher m-i-nax-av-s televizi-it esse filme-NOM muitas vezes 1BDAT-PVR-ver-ST-3ANOM.SG televisão-POSP Ele viu esse filme muitas vezes na televisão.

(TOPADZE, 2008, p.3)
(170) a. es ra cecxl-shi chavvardnil-var! esse o que fogo-POSP cair-1SG.COP Em que fogo eu fui cair!

(BOEDER, 2000, p.288)

\footnotetext{
${ }^{139}$ A evidencialidade indireta em georgiano contrasta com línguas que marcam evidencialidade direta, isto é, aquela em que o falante é testemunha visual do evento.
} 
b. rogor gamaghlebul-xar

como ficar.alto-2SG.COP

Como você ficou alto!

(TOPADZE, 2008, p.6)

As sentenças acima em (170) são casos de miratividade em que os falantes expressam surpresa ou admiração diante daquele acontecimento que pode ser mais desagradável como (170a) ou mais agradável como (170b). Observe que a miratividade envolve as expectativas dos falantes a respeito de determinado fato.

Já casos do perfeito envolvendo sentidos mais experienciais podem ser ilustrados pelos exemplos a seguir. Observe o contraste entre os pares fornecidos por Asatiani (1998):

(171) a. me

$$
\text { a-v-a-shen-e }
$$

$$
\text { saxl-i megobr-is-tvis }
$$

1SG.ERG PV-1AERG.SG-VPR-construir-AOR casa-NOM amigo-GEN-POSP

Eu construí uma casa para meu amigo (eu quis construir).
b. me
a-m-i-shen-eb-i-a
saxl-i
1SG.DAT PV-1BDAT-VPR-construir-ST-SM-3ANOM
casa-NOM

Eu construí a casa. (aconteceu, eu não tinha razão para construir).

(172) a. davaleba ar da-v-c'er-e tarefa-NOM não PV-1AERG-escrever-AOR

Eu não escrevi a tarefa (minha vontade, deliberadamente).

b. davaleba ar da-m-i-c'er-i-a tarefa-NOM não PV-1BDAT-VPR-escrever-SM-3ANOM

Eu não escrevi a tarefa (não deliberadamente). 
De acordo com Asatiani (1998), no caso do último par de sentenças negativas, o sentido passado é o de uma ação não intencional por parte do argumento dativo e que ocorre no passado, em que a vontade ou grau de controle do sujeito é enfraquecida ou mais neutra, essas nuances contrastam com as sentenças no aoristo, indicando ações negadas de forma mais enfática. ${ }^{140}$

De fato, de acordo com Cherchi (1997) e Topadze \& Ramat (2007), as sentenças de ações passadas negadas com o aoristo seriam mais concretas e categóricas do que as sentenças passadas negadas com o perfeito, sendo que no primeiro o agente não teve, especificamente, intenção de realizar determinada ação, observe:
a. naq'in-i
(dzher) ar m-i-ch'am-i-a
sorvete-NOM não
não 1BDAT-VPR-comer-SM-3ANOM

Eu não comi (ainda) o sorvete. (TOPADZE \& RAMAT, 2007, p.15)

b. naq'in-i ar v-ch'am-e, q'el-i m-t'k'i-od-a sorvete-NOM não 1AERG-comer-AOR garganta-NOM 1BDAT-doer-IMPF-3ANOM Eu não comi o sorvete, minha garganta doía. (TOPADZE \& RAMAT, 2007, p.15).

Outro caso de sentido experiencial, mais associado ao significado evidencial do perfeito, é o exemplo abaixo:

$\begin{array}{llll}\text { k'ar-i } & \text { ghia } & \text { da-m-i-t'ov-eb-i-a, } & \text { sabednierod } \\ \text { porta-NOM } & \text { aberta } & \text { PV-1BDAT-VPR-deixar-SM-3ANOM } & \text { felizmente } \\ \text { droulad } & \text { she-m-a-t'qobin-a } & \text { amis } & \text { shesaxeb } \\ & & & \\ \text { a tempo } & \text { PV-1BDAT-VPR-informar-AOR } & \text { 3SG.GEN } & \text { sobre }\end{array}$

Provavelmente eu devo ter deixado a porta aberta, felizmente um vizinho me informou sobre isso.

(TOPADZE \& RAMAT, 2007, p.14)

\footnotetext{
140 Segundo Amiridze (2006), o significado evidencial do perfeito estaria presente em sentenças
} afirmativas, mas não em sentenças negativas. 
No caso acima, o uso da primeira pessoa com o perfeito evidencial pode ser usado para indicar que a ação foi realizada em alguma forma de estado mental inconsciente ou de distração. No exemplo, possivelmente o falante deixou a porta aberta sem se dar conta e só soube do fato ao ser informado por outra pessoa.

Em relação à origem do perfeito, apesar de haver certa dúvida quanto à relação do perfeito com a evidencialidade no georgiano antigo, acredita-se no geral que o perfeito possuía sentido resultativo, variando as hipóteses quanto à ideia de o perfeito já nessa época apresentar ou não o sentido evidencial presente no georgiano moderno.

Dessa forma, enquanto alguns autores acreditam que a evidencialidade no perfeito é uma categoria recente no georgiano, não sendo identificável no georgiano antigo que teria apenas o sentido resultativo; outros acreditam que o resultativo perfeito, já no georgiano antigo, teria traços de evidencialidade, indicando resultados de ações não testemunhadas pelo falante (TOPADZE \& RAMAT, 2007).

Segundo (TOPADZE, 2008), no georgiano antigo, a semântica resultativa do perfeito dominava nos textos, diminuindo gradativamente em georgiano moderno e dando lugar à prevalência da semântica evidencial. Em georgiano moderno, por exemplo, a sentença abaixo poderia ter um significado resultativo ou evidencial, no entanto, o sentido resultativo é obscurecido pelo sentido evidencial que prevalece (GÄUMANN, 2011): $:^{141}$

$$
\begin{array}{lll}
\text { (mas) } & \text { c'ign-i } & \text { c'a-u-k'itx-av-s } \\
\text { 3SG.DAT } & \text { livro-NOM } & \text { PV-VPR-ler-ST-3ANOM.SG }
\end{array}
$$

Ele aparentemente leu o livro. / Ele leu o livro. (GÄUMANN, 2011, p.126)

É interessante notar que essa relação, que se mostra em georgiano através da mesma marcação (i.e. das construções dativas) entre fatores semânticos como não volicionalidade, evidencialidade e resultatividade, também ocorre em outras línguas.

\footnotetext{
${ }^{141}$ Segundo Aikhenvald (2004) apud (TOPADZE, 2008), haveria um caminho evolutivo que partiria do sentido resultativo ao desenvolvimento de um sentido evidencial indireto (não visto), em que o primeiro estágio seria aquele em que o evento denota o resultado de uma ação; no segundo, surgiriam inferências baseadas em traços visíveis ou em algo ouvido; o terceiro seria o desenvolvimento de um significado envolvendo evidencialidade, ou seja, uma informação de segunda mão.
} 
Em macedônio, língua eslava, Friedman (2003) nota que o passado com a forma em - $l$, em detrimento da forma sintética, é usualmente preferida quando a sentença negativa se refere a um evento não volicional ou a um evento sem referência definida no tempo. ${ }^{142}$ Observe, por exemplo, a sentença abaixo que descreve um evento em que o ato praticado é involuntário:

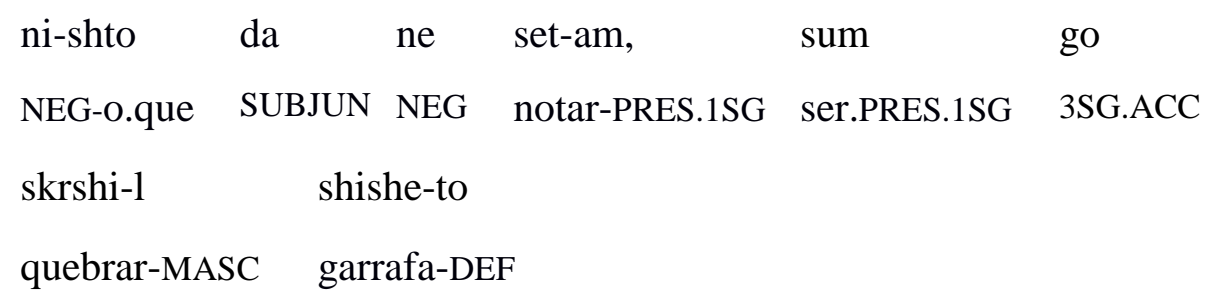

Sem perceber nada, eu quebrei a garrafa.

(FRIEDMAN, 2003, p.204)

Haveria na sentença uma combinação de não volicionalidade, resultatividade e evidencialidade (sentido não confirmativo), já que o participante só percebe que a ação ocorreu a partir do acontecido, i.e., do resultado da ação involuntária (FRIEDMAN, 2003).

Segundo o autor, esse fenômeno é parte de uma tendência tipológica em que perfeitos se desenvolvem em evidenciais não confirmativos (i.e., evidenciais indiretos, não testemunhados).

Ainda que em macedônio não haja a presença do dativo nessas construções com o passado em - $l$, é importante a relação semântica já mencionada entre essa marca e noções de não volicionalidade e evidencialidade, relação que também existe em georgiano.

Em línguas leste-caucasianas, também existe relação próxima, e tal como no georgiano, são as construções afetivas (i.e., com o caso dativo ou o chamado caso afetivo) que a apresentam.

Nas línguas leste-caucasianas, verbos com tradução aproximada de 'achar, deparar-se, descobrir' apresentam usualmente um argumento experienciador nessas

142 Por exemplo, uma sentença se referindo a uma afirmação geral como 'eu não sei' (sem definição exata de tempo) seria melhor expressa em macedônio com o passado em -l 'ne sum znael' do que com a forma sintética 'ne znaev' (FRIEDMAN, 2003). 
línguas marcado ou com o caso dativo ou afetivo a depender da língua (observe o exemplo (156) da língua tsez mostrado na seção anterior).

De acordo com Forker (2018), o uso desses verbos como verbos leves ocorre tanto para marcar construções de probabilidade, condicionais e concessivas, quanto podem adquirir sentidos evidenciais. Em seu sentido evidencial, esses verbos marcariam uma evidencialidade indireta que ocorreria a partir de inferências feitas por meio de evidências diretas ou visíveis, em que o falante, através da observação direta ou da descoberta do resultado de um evento, faz uma inferência sobre como aquele evento se deu (FORKER, 2018). Observe os exemplos das línguas hinuq e archi, respectivamente:

$\begin{array}{clllll}\text { (177) a. rok’o } & \text { gosme } & \text { azhe } & \text { iLi } & \text { ashi-sh } & \text { me } \\ \text { raiz } & \text { sem } & \text { árvore } & \text { similar } & \text { achar-PAST } & \text { 2SG }\end{array}$

Você (masculino) acabou por ser similar a uma árvore sem raiz. (FORKER, 2018, p.502)

$\begin{array}{lllll}\text { b. tow } & \text { w-irX }{ }^{\mathrm{w}} \text { ni-li } & \text { Xu-t’ushaw, } & \mathrm{zh}^{\mathrm{w}} \text { en } & \text { towmus } \\ \text { ele } & \text { MASC-trabalhar-CONVB } & \text { achar.MASC-NEG } & \text { 2PL.ERG } & \text { 3SG.DAT } \\ \text { arsi } & \text { kLaba! } & & & \\ \text { dinheiro } & \text { dar.IMP } & & \end{array}$

Apesar de ele acabar não trabalhando, dê-lhe dinheiro! (KIBRIK, 1977 apud FORKER, 2018, p.502)

Outra semelhança com o caso do georgiano pode ser encontrada nessas línguas. Segundo Forker (2018), em línguas como bagvalal, a descoberta da evidência e as inferências decorrentes podem relacionar-se com um certo grau de surpresa por parte do falante, sendo uma construção frequentemente descrita como 'admirativa'.

Como discutimos sobre o georgiano, sentidos de miratividade também estão relacionados às construções inversas com o dativo, mais um sentido marcado de forma semelhante às construções evidenciais e experienciais.

Acreditamos que essas semelhanças na marcação (seja por meio do dativo ou outra forma) de sentidos envolvendo evidencialidade, não volicionalidade (o que inclui sentidos experienciais) e outros aqui apontados, em diferentes línguas, não são mera 
coincidência e sim indicam que há semelhanças ou proximidades na forma como esses eventos são conceitualizados, refletindo-se em marcações similares desses eventos.

Uma dessas similaridades, a partir dos dados que vimos nesta seção, é a relação entre não volicionalidade, marcação diferencial e evidencialidade. O falante, por ter obtido a informação por meios indiretos, como inferência ou ter ouvido falar, não é uma testemunha direta, descrevendo o acontecido como aparentemente ele acha que se deu, o que ocasiona um evento mais marcado semanticamente e favorecendo uma marcação não canônica. É interessante que o desenvolvimento desse significado a um significado menos volitivo tem condições favoráveis, já que quando o falante é o agente da ação, a marcação evidencial do perfeito traz o significado mais experiencial de que ele pode não se lembrar direito do acontecido ou pode não ter prestado suficiente atenção, sendo um agente comparadamente menos volitivo.

\subsection{Causatividade e verbos causativos indiretos em georgiano}

Como é possível recordar da discussão feita no capítulo 3, diversos autores, tais como Grimshaw (1990), Pesetsky (1995), Arad (1998), Reinhart (2002), dentre outros, consideraram ou basearam suas análises dos verbos psicológicos, e sua variação no mapeamento de seus argumentos, na diferença entre eventos estativos e causativos. Geralmente, os comportamentos peculiares desses verbos eram atribuídos a um ou outro tipo de evento (estativo ou causal a depender).

A análise vista de Croft (1993), por exemplo, atribui a variação translinguística apresentada pelos verbos experienciais (em relação, por exemplo, à marcação do estímulo e experienciador) aos verbos mentais estativos.

Assim, os verbos psicológicos que apresentariam variação seriam verbos estativos como like 'gostar, amar', know 'saber', etc., que não envolveriam mudança de estado ou transmissão de força. Em contraste, verbos mentais causativos (estímulo sempre na posição de sujeito), incoativos (experienciador sempre na posição de sujeito) e de atividade (experienciador sempre na posição de sujeito) não apresentariam variação na marcação devido a terem uma estrutura de evento causal ou mais volitiva. 
Assim, por não envolverem mudança de estado, verbos mentais estativos não teriam uma direcionalidade causal única, apresentando variação na marcação do estímulo e experienciador.

Como veremos no capítulo 7, apesar de concordarmos com uma caracterização de verbos psicológicos como não tendo uma direcionalidade conceitual única, sendo bidirecionais, discordamos da análise do autor de que apenas verbos mentais estativos apresentariam essa estrutura conceitual, havendo exemplos do próprio georgiano que mostrariam que há também variações de marcação com verbos causativos e incoativos.

Naess (2007), por exemplo, nota uma série de contraexemplos provenientes de outras línguas que indicariam que a variação não ocorreria nas línguas apenas com verbos mentais estativos.

Em bhojpuri, o autor nota que há uma alternância entre o verbo 'ver' com um experienciador mais volicional e o verbo 'ver' com um sentido mais acidental, de 'bater o olho':

$\begin{array}{llll}\text { (178) a. ham } & \text { okaraa } & \text { ke } & \text { dekhnii } \\ \text { 1SG.NOM } & \text { 3SG } & \text { ACC } & \text { ver.TR }\end{array}$

Eu vi ele. (VERMA, 1990 apud NAESS, 2007, p.187)

b. hamraa uu laukal 1SG.OBL 3SG.NOM ver-INTR

Eu acabei por ver ele. (VERMA, 1990 apud NAESS, 2007, p.187)

Interessantemente, o experienciador oblíquo ocorre com o evento com uma leitura mais eventiva (178b), sendo mais facilmente interpretado como uma mudança de estado (havendo uma mudança de percepção em que o estímulo aparece no campo de visão do experienciador) do que um estado como (178a) (NAESS, 2007).

$\mathrm{O}$ autor também cita outros exemplos de verbos incoativos com experienciadores oblíquos como kathmandu newari, língua tibetana, em que o experienciador de verbos incoativos pode aparecer com o genitivo ou dativo: 
mirä-yä/-yäta tyänhul-a

Mira-GEN/-DAT cansar-PAST

Mira ficou cansada. (BICKEL, 2004 apud NAESS, 2007, p.187)

O mesmo ocorreria em lhomi, uma língua tibetana de outro ramo linguístico, em que o experienciador seria marcado com o caso dativo em verbos incoativos:

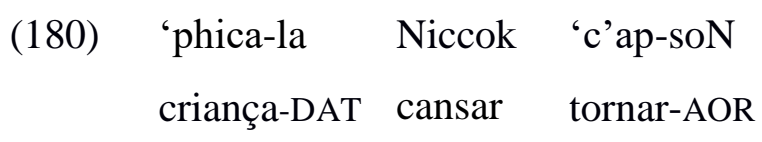

A criança ficou muito cansada. (BICKEL, 2004 apud NAESS, 2007, p.188)

Em georgiano, muitos verbos com leitura incoativa e que, inclusive, apresentam o infixo incoativo - $d$ ocorrem com o experienciador no dativo:

sandro-s u-quar-d-eb-a nino

Sandro-DAT VPR-amar-INC-ST-3ANOM Nino.NOM

Sandro está apaixonado por Nino. (Sandro se apaixona por Nino).

Observe que o verbo acima $u$-qvar-d-eb-a é a versão incoativa do verbo indireto u-qvar-s 'amar' e denota o surgimento da experiência, a mudança de estado. Outros verbos indiretos incoativos são: bezr-d-eb-a 'entediar-se, estar entediado', $a$-vic 'q- $d$-eb$a$ 'esquecer', dentre outros.

Além de verbos incoativos com o experienciador no caso dativo, o georgiano também apresenta variação com verbos causativos, indicando que estes não estão imunes à variação nas línguas, ou seja, a marcação não canônica com o dativo ou mesmo a variação no mapeamento de experienciador e estímulo não é só uma questão aspectual ou causal como por vezes é argumentado na literatura. Embora fatores aspectuais e também de causação, sem dúvida, possam estar envolvidos na marcação distintiva observada nas línguas, nem sempre constituem a única razão ou motivação. 
Em georgiano, sentenças causativas podem ser formadas tanto a partir de verbos intransitivos quanto transitivos. Usualmente, a derivação de intransitivos é feita a partir da vogal pré-radical - $a$ - em adição ao sufixo temático - $e b$-, observe:

(182) a. q'ep-s

latir-3ANOM.SG

Ele late. (GUREVICH, 2006, p. 149)

b. v-a-q'ep-eb

1ANOM-VPR-latir-ST

Eu faço ele latir. (GUREVICH, 2006, p. 149)

A causativização de verbos transitivos pode também apresentar a adição do sufixo causativo -in, observe:
a. amxanag-s c'eril-s s-c'er-s
amigo-DAT carta-DAT 3BDAT-escrever-3ANOM.SG
Ele escreve uma carta ao amigo. (GUREVICH, 2006, p. 150)
b. amxanag-is-tvis c'eril-s mas v-a-c'er-in-eb amigo-GEN-POSP carta-DAT 3SG.DAT 1ANOM-VPR-escrever-CAUS-ST Eu faço ele escrever uma carta para o amigo. (GUREVICH, 2006, p. 149)

A forma com a vogal pré-radical - $a$ - mais $-e b$ - é a estrutura transitivo-causativa menos marcada, relativamente à forma em -in, sendo encontrada na formação de verbos transitivos no geral na língua, inclusive na derivação verbal de adjetivos e substantivos (cf. GUREVICH, 2006). Como Gurevich (2006) menciona, inclusive, já foi sugerida na literatura uma conexão histórica entre a versão neutra - $a$ com a vogal pré-radical $-a$ presente na formação causativa. 
A seguir, veremos alguns grupos de verbos em georgiano com origem causativa e que apresentam variação na marcação do sujeito, mostrando uma marcação em que o experienciador é marcado com o caso dativo.

Tuite (2009), por exemplo, discute alguns grupos de verbos em georgiano que seriam morfologicamente causativos (apresentando a estrutura com $-a-\mathrm{e}-e b-$, e em alguns casos, com o sufixo causativo -in), mas que, assim como os verbos experienciais que temos visto, podem ocorrer em construções indiretas.

Esses grupos de verbos distanciam-se do esperado na medida em que, apesar de serem verbos com morfologia causativa (o que os torna 'formalmente' transitivos), o sujeito desses verbos (o causador e agente) pode ser omitido e apresentam, ainda, um argumento no dativo que se assemelha ao experienciador dativo das construções indiretas vistas.

Característica que provavelmente é correlata, como Tuite (2009) discute, ao fato de serem verbos que, em sua maioria, denotam sensações involuntárias, sintomas, mudanças de estado, etc., semântica típica de verbos psicológicos com sujeitos experienciadores. Observe os exemplos encontrados pelo autor:

\section{(184) a. ertxel kimi-is lekcia-ze da-m-a-k'ank'al-a uma vez química-GEN aula-POSP PV-1BDAT-VPR-bocejar-3ANOM.AOR Uma vez eu bocejei em uma aula de química. (TUITE, 2009, p. 3)}

b. dzalian a-civd-a,

\begin{tabular}{|c|c|c|}
\hline gach'irvebul-ma & maisuric & k’i \\
\hline sofrendo-ERG & blusa.NOM & mas \\
\hline m-a-k'ank'al-eb-c & & mainc \\
\hline
\end{tabular}

PV-1AERG-VPR-puxar-AOR

Ficou muito frio, sofrendo (do frio) eu puxei minha blusa, mas eu ainda tremia. (TUITE, 2009, p. 3)

c. v-k’vd-eb-i

liv t'ailer-ze m-a-bod-eb-s

1ANOM.SG-morrer-ST-1ANOM Liv.Tayler-POSP 1BDAT-VPR-delirar-ST-3ANOM.SG mas-ze

3SG-POSP

Eu estou morrendo pela Liv Tyler, estou louco por ela. (TUITE, 2009, p. 3) 
Note que nos três exemplos o experienciador de verbos como 'tremer, bocejar, delirar' é marcado com o caso dativo, sendo todos de morfologia transitiva-causativa envolvendo algum tipo de sensação física. No último caso, o verbo 'delirar' (de febre, por exemplo) é usado com sentido metafórico de 'estar louco por alguém, delirar por alguém'.

Tuite (2009) divide os verbos que chama de agentless transitives 'transitivos sem agente' em três grupos. O primeiro, ilustrado pelos exemplos a seguir, e chamado pelo autor de 'causativos sem agente facultativos', é composto por verbos morfologicamente causativos que podem alternar entre uma estrutura bivalente (i.e., causativa e direta) e monovalente (sem presença do agente, o causador, e indireta) a depender do contexto. Semanticamente, segundo o autor, são verbos que denotam sensações corporais involuntárias como tremer, delirar, arrepiar-se, etc.

O contraste entre os usos mono- e bivalente é exemplificado por Tuite (2009) pelas sentenças em (185) e (186). As sentenças em (185a) e (186a) são causativas, marcadas nos verbos $a-k$ 'ank'al-eb-s e $a$-zhrzhol-eb-s pela vogal pré-radical -a- e pelo sufixo temático $-e b$. Como é esperado de uma construção direta transitiva, o agente é marcado, nas Séries II do aoristo, pelo caso ergativo; já nas sentença indiretas, o experienciador é marcado com o caso dativo e o que seria a causa, o frio, é marcado de forma oblíqua:

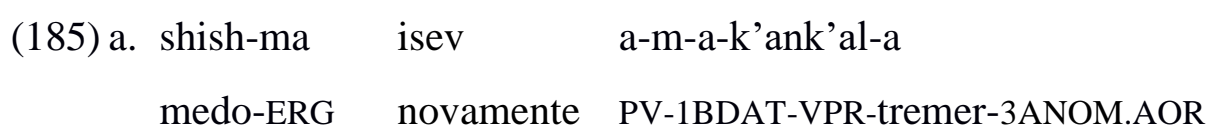

O medo me fez tremer novamente. (TUITE, 2009, p. 12)

b. siciv-isa-gan a-m-a-k'ank'al-a

frio-GEN-POSP PV-1BDAT-VPR-tremer-3ANOM.AOR

Eu tremi de frio. (TUITE, 2009, p. 12) 

(186) a. kal-i usiamovno mogoneba-m she-a-zhrzhol-a mulher-NOM desagradável lembrança-ERG PV-VPR-tremer-3ANOM.AOR Uma lembrança desagradável fez a mulher tremer. (TUITE, 2009, p. 13)

b. xazarula-s siciv-isa-gan she-a-zhrzhol-a xazarula-DAT frio-GEN-POSP PV-VPR-tremer-3ANOM.AOR A xazarula (nome de árvore) estremeceu do frio. (TUITE, 2009, p. 13)

Os exemplos em (187) abaixo, fornecidos por falantes, exemplificam outros verbos causativos sem agente, em que o nominal no dativo marca o participante experienciador e o nominal nominativo, quando presente (como 187b), marca o estímulo:

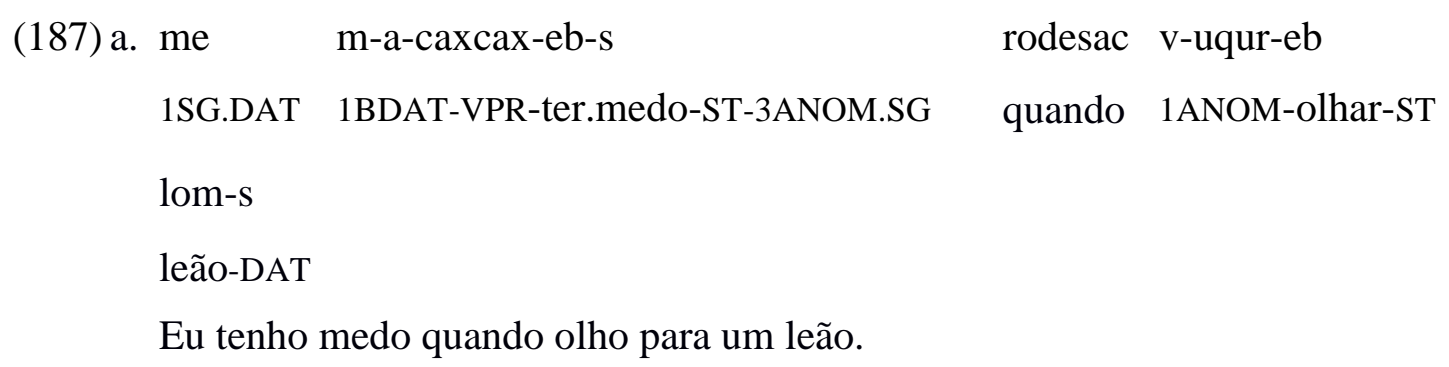

Eu tenho medo quando olho para um leão.
b. chem-s sul-s a-trtol-eb-s shen-i siqvarul-i meu-DAT alma-DAT VPR-tremer-ST-3ANOM.SG seu-NOM amor-NOM Minha alma treme por seu amor.
c. me m-a-bod-eb-da
1SG.DAT 1BDAT-VPR-delirar-ST-IMPF quando 1BDAT-ter-3ANOM
sicxe
febre.NOM
Eu delirava quando tive febre.

É interessante que contrastes de volicionalidade são também observados. Uma parte desses verbos causativos monovalentes indiretos pode também alternar para construções diretas. Nesse caso, o significado implicado pela interpretação direta parece 
ser relativo ao seu uso indireto, ou seja, verbos que expressam processos com pouco ou nenhum controle adquirem, a partir da construção direta, uma interpretação em que o sujeito passa a ter um grau de controle sobre o evento, observe:

(188) a. ga-m-a-zmor-eb-s

PV-1BDAT-VPR-alongar-ST-3ANOM.SG

$\mathrm{Eu}$ sinto a necessidade de me alongar.

b. ga-v-i-zmor-e

PV-1AERG-VPR-alongar-AOR

Eu me alonguei.

O nominal dativo, no caso de (188a), é marcado pelo conjunto de afixos B e recebe uma caracterização em que marca um experienciador típico de construções indiretas, como em verbos experienciais, em que o participante não possui controle sobre o evento, apenas experienciando de alguma forma seus efeitos. $\mathrm{O}$ exemplo em (b) ilustra o contraste entre o verbo indireto em (a) e o verbo com uma interpretação mais ativa: enquanto em (188b), o sujeito teria um maior controle sobre o evento de alongarse - sendo, aliás, marcado no verbo pelo conjunto de afixos $\mathrm{A}$-, em (188a), é passado o sentido de não ter controle, em que o participante experiencia o desejo ou necessidade de alongar-se.

O segundo grupo dividido por Tuite (2009) consiste em um subgrupo dos verbos chamados por ele de verbos sem agente facultativos, diferindo do anterior apenas por não apresentarem a vogal pré-radical - $a$ - e o sufixo temático - $e b$-. Alguns exemplos desses verbos estão ilustrados em (189). Semanticamente, são verbos que denotam dores e desconforto muscular (TUITE, 2009).

(189) a. ga-m-qin-av-s

PV-1BDAT-sentir-se.gelado-ST-3ANOM.SG

Eu me sinto gelado. 
b. gverd-shi m-chxvlet-s

lado-POSP 1BDAT-sentir.dor-3ANOM.SG

Eu sinto uma dor lancinante no lado do corpo.

O terceiro grupo divisado por Tuite (2009) é o chamado por ele de verbos com morfologia causativa lexicalmente sem agente. Diferente do primeiro grupo de verbos em que a presença do agente é facultativa (i.e., depende do contexto), esse grupo de verbos é sempre monovalente, i.e., não aparece com um argumento agente.

De forma similar aos contrastes de volicionalidade vistos anteriormente, muitos desses verbos podem aparecer tanto na construção direta quanto na construção indireta. A construção indireta implica que a ação é involuntária, não intencional, por parte do experienciador no caso dativo, leitura que pode ser explicada pela semântica desses verbos. A construção direta, em contrapartida, acarretaria o significado de que a ação é intencional ou que foi feita de propósito.

O contraste entre as duas construções pode ser visualizado em (190) e (191). Enquanto a construção indireta em (190a) e (191a) denota ações involuntárias de 'tossir', e 'vomitar', a construção direta em (190b) e (191b) denota ações intencionais por parte do agente, sendo mais controladas ou voluntárias.

(190) a. c'amosvl-is dghe-s rodesac gaciebuli vq'opilvar, sashinlad partida-GEN dia-DAT quando resfriado 1SG.estar.PART terrivelmente m-a-xvel-eb-da.

1BDAT-VPR-tossir-ST-IMPF

No dia da partida eu fiquei resfriado, eu tossia terrivelmente. (TUITE, 2009, p.17)

b. didi k'aciv-it much'-shi v-a-xvel-eb meu-DAT homem-INST palma-POSP 1ANOM-VPR-tossir-ST

Sendo um adulto eu tusso na minha mão. (TUITE, 2009, p. 17) 
$\begin{array}{rll}\text { a. rac } & \text { v-ch'am-e, } & \text { gadmo-m-a-rc'q-i-a } \\ \text { que } & \text { 1AERG-comer-AOR } & \text { PV-1BDAT-VPR-vomitar-ST-3ANOM }\end{array}$

Eu vomitei o que comi. (RAYFIELD, 2006)

b. bavshv-ma gadmo-m-a-rc'q-i-a

criança-ERG PV-1BDAT-VPR-vomitar-ST-3ANOM

A criança vomitou em mim.

Segundo Tuite (2009), esses verbos seriam característicos do que chamam de verbos de 'emanação corporal', denotando reações involuntárias provocadas por estímulos internos corporais, ainda que parcialmente controláveis pelo participante, como tossir, espirrar, arrotar, soltar gases e vomitar. Em razão dessa semântica, verbos como esses também poderiam ocorrer com um objeto, denotando, por exemplo, aquilo que é expelido, observe os exemplos abaixo em (192a e 192b). Nesses casos, a construção direta transitiva é favorecida:

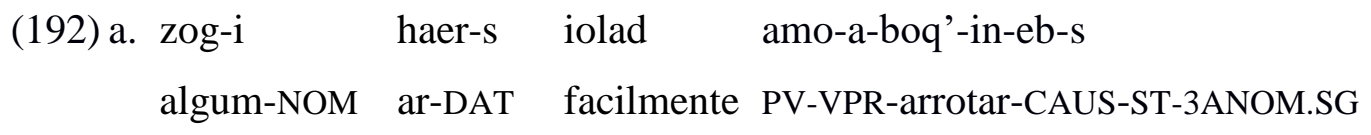

Alguns bebês arrotam ar facilmente. (TUITE, 2009, p.23)

b. sisxl-i amo-v-a-xvel-e

sangue-NOM PV-1AERG-VPR-tossir-AOR

Eu tossi sangue. (TUITE, 2009, p.23)

Os casos vistos aqui do georgiano e outras línguas mostram que a variação no mapeamento de argumentos de verbos experienciais não está restrita nas línguas a eventos estativos, havendo também variação em relação a verbos incoativos e causativos.

Ademais, esses verbos também indicam a importância de contrastes de volicionalidade nesses eventos e também mostram nuances conceituais, exploradas no capítulo 7, entre eventos construídos ora como causados internamente ou externamente 
por uma força não controlável pelo experienciador, ora como um evento experiencial que surge a partir do próprio experienciador, podendo ser dirigido, inclusive, ao estímulo. 


\section{VERBOS EXPERIENCIAIS: OUTRAS DISCUSSÕES RELEVANTES}

\subsection{Introdução}

Neste capítulo faremos algumas discussões remanescentes que acreditamos ser importantes e relevantes para este trabalho.

A seção 6.2 tratará de outras construções nas línguas, para além das construções dativas vistas, que também codificam eventos experienciais. Discussão que não tem a pretensão de escrutinar cada construção, nem cada significado envolvido, dado o recorte desta tese e dada a complexidade da tarefa, mas sim oferecer um panorama mais geral e apontar dados que serão relevantes para a caracterização conceitual no capítulo 7.

Na seção 6.3, veremos, através principalmente da análise de Maldonado (2002) do espanhol, algumas relações conceituais entre verbos experienciais e outras construções com dativos, tais como de posse externa e de transferência.

Na seção 6.4, será abordada a conexão próxima entre dativos e locativos, sendo utilizados dados de línguas leste-caucasianas. Essa conexão será importante para nossa argumentação no capítulo 7. Como consequência dessa relação próxima, torna-se relevante discutir o papel que locativos e adposições (preposições e posposições) teriam na gramática das línguas e na conceitualização de eventos de acordo com a GC de Langacker.

\subsection{Outras construções com verbos experienciais nas línguas}

Como vimos nos capítulos 3 e 5, há grande variação no mapeamento de experienciador e estímulo de verbos experienciais: por vezes, o experienciador é marcado com um caso canônico, normalmente aquele atribuído a sujeitos na língua, por outras, é marcado com um caso canônico atribuído a objetos diretos na língua. Ainda, uma terceira possibilidade, é a marcação do experienciador com um caso não canônico, o dativo ou, às vezes, outros casos como genitivo.

Interessantemente, o fato de existir uma dessas possibilidades na língua não exclui necessariamente a presença das outras em uma mesma língua. Além do mais, 
construções diferentes marcando eventos experienciais também coexistem nas línguas, como o uso de construções transitivas, médias, etc.

O intuito desta seção não é escrutinar todas essas possibilidades, mas oferecer um panorama dessa variação e argumentar que essa variação não está pautada em diferenciações dicotômicas de significado, mas sim em nuances e gradações de significado que não existem isoladamente dentro das línguas e que também estão sujeitas a pressões no sistema.

Outro ponto importante é argumentar que essa variação é um indício de como eventos experienciais são conceitualizados, o que envolve também formas diferentes de focar aspectos distintos dessa conceitualização.

Em georgiano, devido aos diferentes padrões de marcação, observados, por exemplo, por meio das chamadas classes verbais, é possível notar que há verbos experienciais que apresentam padrões de marcação outros que não só o padrão indireto focado aqui.

A tabela abaixo ilustra alguns desses verbos com diferentes padrões de marcação (indicados através da classe para facilitar), começando por verbos de sensação física, em seguida verbos emocionais, de cognição e, ao fim, de percepção.

\begin{tabular}{|c|c|c|}
\hline Classe I & Classe II & Classe III \\
\hline ghl-is 'cansar alguém' & $\begin{array}{l}i \text {-ghl-eb-a 'ficar cansado, } \\
\text { estar cansado' }\end{array}$ & t'iri-s 'chorar' \\
\hline $\begin{array}{l}i \text {-dzin-eb-s 'colocar alguém } \\
\text { para dormir, hipnotizar' }\end{array}$ & $c^{\prime}$ 'itl-d-eb-a 'enrubescer' & $i$-cin-is 'rir' \\
\hline $\begin{array}{l}a-c \text { 'ux-eb-s 'incomodar, } \\
\text { preocupar alguém' }\end{array}$ & $\begin{array}{l}\text { ghel-av-s 'preocupar-se } \\
\text { com alguma coisa' }\end{array}$ & $\begin{array}{ll}\text { nerviul-ob-s } & \text { 'estar } \\
\text { nervoso/ansioso, } & \\
\text { preocupar-se' } & \end{array}$ \\
\hline $\begin{array}{ll}a-g h e l-e b-s & \text { 'preocupar } \\
\text { alguém' } & \end{array}$ & gizhd-eb-a 'enlouquecer' & $\begin{array}{l}\text { k'vnes-is 'lamentar, } \\
\text { sofrer' }\end{array}$ \\
\hline $\begin{array}{l}a \text {-shin-eb-s 'assustar } \\
\text { alguém' }\end{array}$ & $\begin{array}{l}t^{\prime} k \text { 'b-eb-a 'aproveitar, ter } \\
\text { prazer em fazer algo' }\end{array}$ & chiv-is 'reclamar' \\
\hline$a$-braz-eb-a 'irritar alguém' & braz-d-eb-a 'irritar-se' & $\begin{array}{l}\text { e-ch'vian-ob-s } \\
\text { ciúmes' }\end{array}$ \\
\hline $\begin{array}{l}\text { a-k'maqopil-eb-s 'satisfazer } \\
\text { alguém' }\end{array}$ & mshvidd-eb-a 'acalmar-se' & grdzn-ob-s 'sentir' \\
\hline
\end{tabular}




\begin{tabular}{|l|l|l|}
\hline & & $\begin{array}{l}\text { nan-ob-s 'arrepender- } \\
\text { se' }\end{array}$ \\
\hline $\begin{array}{l}\text { tvl-is 'considerar alguma } \\
\text { coisa' }\end{array}$ & $\begin{array}{l}\text { e-tanxm-eb-a 'concordar, } \\
\text { assentir' }\end{array}$ & pikr-ob-s 'pensar' \\
\hline $\begin{array}{l}\text { i-geb-s 'entender, } \\
\text { compreender alguma coisa' }\end{array}$ & ech'v-ob-s 'duvidar' \\
\hline $\begin{array}{l}\text { i-cn-ob-s 'conhecer alguém' } \\
\text { i-xil-av-s 'discutir, } \\
\text { examinar, deliberar' }\end{array}$ & & \\
\hline $\begin{array}{l}i \text {-vic' } q \text {-eb-s 'esquecer' } \\
\text { u-smen-s 'escutar' }\end{array}$ & & \\
\hline $\begin{array}{l}\text { xed-av-s 'ver' } \\
\text { sinj-av-s } \\
\text { (comida, bebida)' }\end{array}$ & & \\
\hline
\end{tabular}

Tabela 23: Verbos psicológicos com morfologia de outras Classes verbais

Algumas diferenciações semânticas, a princípio, podem ser notadas, como o fato de verbos psicológicos de Classe I denotarem eventos mais causais ou de mais transitividade (como ter mais de um participante) tais como ghl-is 'cansar alguém', $i$ dzin-eb-s 'colocar alguém para dormir, hipnotizar', $a-c$ 'ux-eb-s 'incomodar, preocupar alguém', $a$-braz-eb-a 'irritar alguém'. Já a Classe II apresenta mais verbos incoativos como braz-d-eb-a 'irritar-se', gizhd-eb-a 'enlouquecer', c'itl-d-eb-a 'enrubescer'. E a Classe III, por sua vez, apresentaria verbos mais característicos de atividades atélicas como t'iri-s 'chorar' e $i$-cin-is 'rir', além de verbos de fala emocionais tais como $k$ 'vnesis 'lamentar, sofrer', chiv-is 'reclamar'.

Essas distinções, no entanto, não são absolutas, como é possível notar pela própria tabela, já que nem todos os verbos nas colunas um, dois e três são causais, incoativos e atélicos respectivamente. Por exemplo, o verbo da coluna dois $i$-ghl-eb-a 'ficar cansado, estar cansado', além de um sentido incoativo, também pode ter um significado mais estativo como me da-v-i-ghal-e 'eu estava cansado'. De maneira 
similar, pode-se argumentar que o verbo $x e d-a v-s$ 'ver' da coluna um é mais estativo e não causal, assim como $e$-ch 'vian-ob-s 'ter ciúmes' da coluna três.

De fato, quando há sentidos aproximados com padrões de marcação distintos é difícil por vezes identificar com precisão qual a diferença, principalmente nos casos em que as raízes são as mesmas, como entre o verbo indireto $e$-ech'v-eb-a 'ter dúvida' e o verbo de morfologia de Classe III ech 'v-ob-s 'duvidar' (cf. discussão de Cherchi (1997) sobre possíveis diferenças entre verbos indiretos e de Classe III com mesma raiz).

Interessantemente, quando perguntado a falantes nativos, o que se obtém são respostas que variam de acordo com os verbos em questão, mostrando nuances de significado ou 'especializações' e até graus de frequência de uso diferenciados. Por exemplo, algumas formas de Classe III que constam em dicionários, correspondentes às formas indiretas, são muitas vezes tidas como incorretas ou julgadas estranhas por falantes, talvez devido à sua baixa frequência de uso, como shish-ob-s e dzul-ob-s, versões de Classe III dos verbos indiretos $e$-shin-ia 'ter medo' e $s$ - $d z u l-s$ 'odiar'.

Em outros casos, nuances de aspecto ou intencionalidade parecem também salientes, por exemplo, ao se solicitar a tradução de formas como m-a-xvel-eb-s (forma indireta de 'eu tusso') e v-a-xvel-eb (forma direta de 'eu tusso'), além de aspectos envolvendo volição (cf. seções 5.5 e 5.8), os falantes preferem traduzir as duas formas quando isoladas, respectivamente, como 'eu tenho uma tosse, eu estou com tosse' e 'eu tusso, eu estou tossindo', parecendo haver aí uma preferência a um significado mais estativo e durativo no primeiro e no segundo mais como uma atividade.

O mesmo ocorre com o verbo indireto $e$-ech 'v-eb-a 'ter dúvida' e o verbo de morfologia de Classe III ech'v-ob-s 'duvidar', o primeiro pode ser traduzido como 'eu tenho uma dúvida' m-e-ech 'v-eb-a e o segundo como 'eu duvido' v-ech'v-ob.

Em relação a esse par, um falante informou que o verbo indireto é mais frequentemente usado sozinho como em resposta a algo como 'eu duvido disso', já o verbo direto de Classe III seria mais usado seguido de outra sentença como em v-ech'vob rom es mart'ivi ikneba 'eu duvido que isso será fácil'. ${ }^{143}$

\footnotetext{
${ }^{143}$ Kemmer (1993, p. 137) faz uma discussão sobre o que chama de eventos mentais complexos, que seriam justamente aqueles em que o evento principal seria expresso por um verbo mental como 'eu penso, eu duvido' seguido de um evento dependente 'eu penso/duvido que ele irá à festa'. É interessante notar que, segundo a autora, há línguas em que o mesmo verbo é usado tanto em eventos complexos quanto em eventos simples, enquanto em outras, haveria um verbo que seria quase que exclusivamente usado em eventos complexos. Situação essa que talvez se assemelhe ao caso descrito do georgiano.
} 
Ainda que esses fatores de diferenciação precisem ser mais detalhadamente pesquisados para se ter certeza de sua validade, nota-se a princípio que certas especializações de significado parecem emergir para diferenciar formas com sentidos próximos, fazendo com que ocorram na língua de maneira complementar. Já outras formas parecem decair em detrimento de formas mais usadas e arraigadas.

Em outros casos, o sentido de determinada forma segue tendências de significado na língua, arraigadas na forma de determinados padrões, como nos casos de intencionalidade e aspecto, em que, por exemplo, 'verbos com morfologia de Classe III têm uma tendência a ser atélicos'.

Outro exemplo disso é a tendência de verbos indiretos terem um sentido mais experiencial, como é o caso do verbo indireto h-gon-ia 'achar, parecer, ter a impressão de', do que suas eventuais contrapartes diretas, caso de pikr-ob-s 'pensar'.

É interessante também observar que frequentemente os verbos de morfologia de Classe diferente formam pares: o verbo ghel-av-s 'preocupar-se com alguma coisa' na coluna um, por exemplo, não é causal (no sentido de o estímulo causar uma emoção no experienciador) comparadamente à sua contraparte a-ghel-eb-s 'preocupar alguém', formando um par com este em termos de significação. ${ }^{144}$

A princípio, esse par poderia ser distinguido por meio da transitividade, i.e., $a$ ghel-eb-s 'preocupar alguém' poderia ser considerado mais transitivo que ghel-av-s 'preocupar-se com alguma coisa', já que, por exemplo, codifica os dois participantes, estímulo e experienciador; enquanto o último, codificaria fundamentalmente $\mathrm{o}$ experienciador. Apesar dessa distinção, é interessante notar que o estímulo pode ser marcado perifrasticamente (isto é, com uma posposição) com verbos como ghel-av-s 'preocupar-se com alguma coisa'. Essa possibilidade parece ser uma opção disponível para a maior parte, senão todos, desses verbos, o que é interessante sob um ponto de vista da estrutura conceitual dos eventos experienciais.
a. me
V-ghel-av
am
p'roblema-s-tan
dak'avshirebit
1SG.NOM 1ANOM-preocupar-ST esse problema-DAT-POSP sobre

Eu me preocupo com esse problema.

\footnotetext{
${ }^{144}$ Interessantemente, esse par, em seu sentido mais 'concreto', pode significar 'agitar, mexer', sendo possivelmente uma extensão a um estado emocional em que o participante é 'agitado', 'mexido'. Em português (também em inglês), extensão similar também se observa, em que 'estar mexido' por alguém ou por alguma situação pode significar algum tipo de perturbação emocional.
} 


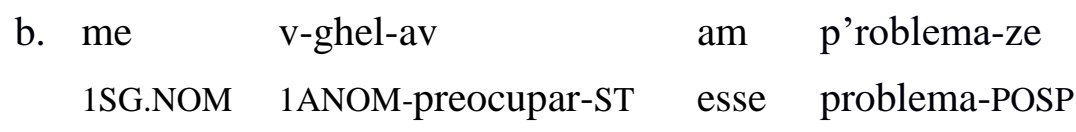

Eu me preocupo com esse problema.

Tanto a possibilidade em (a) quanto em (b) acima são possíveis, a primeira sentença tem o estímulo marcado com dak'avshirebit 'com relação a' acompanhado da posposição -tan 'com' marcando o nome. Já a segunda opção marca o estímulo através da posposição -ze 'sobre'. Essa marcação do estímulo se assemelha a de outros verbos intransitivos: compare, por exemplo, com o verbo de morfologia de Classe III nerviul$o b-s$ 'estar nervoso/ansioso, preocupar-se', em que o estímulo também é marcado de forma perifrástica:

$$
\begin{array}{lllll}
\text { me } & \text { v-nerviul-ob } & \text { am } & \text { p'roblema-s-tan } & \text { dak'avshirebit } \\
\text { 1SG.NOM } & \text { 1ANOM-preocupar-ST } & \text { esse } & \text { problema-DAT-POSP } & \text { sobre }
\end{array}
$$

Eu me preocupo com esse problema.

Estrutura diferente da contraparte causativa $a-c$ ' $u x-e b-s$ 'incomodar, preocupar alguém' e $a$-ghel-eb-s 'preocupar alguém', observe:

(195) a. es ech'vian-ob-s m-a-c'ux-eb-s esse problema.NOM 1BDAT-VPR-preocupar-ST-3ANOM.SG Esse problema me preocupa.
b. es
p'roblema
m-a-ghelv-eb-s
esse problema.NOM
1BDAT-VPR-preocupar-ST-3ANOM.SG
Esse problema me preocupa. 
O uso de posposições (ou preposições em outras línguas) na marcação do estímulo é particularmente interessante e, sem dúvida, mereceria um tratamento e um estudo mais detalhado do que aquele que será possível nesta tese. No entanto, parecenos que a posposição -ze e também o caso instrumental são os modos mais frequentemente usados de codificação, a escolha de um ou outro aparentemente dependendo do significado do verbo.

Como observado acima, tanto verbos de morfologia de Classe II quanto III podem aparecer com ou sem o estímulo. Quando o estímulo é codificado, uma posposição é usada, nos casos abaixo, a posposição -ze é usada:

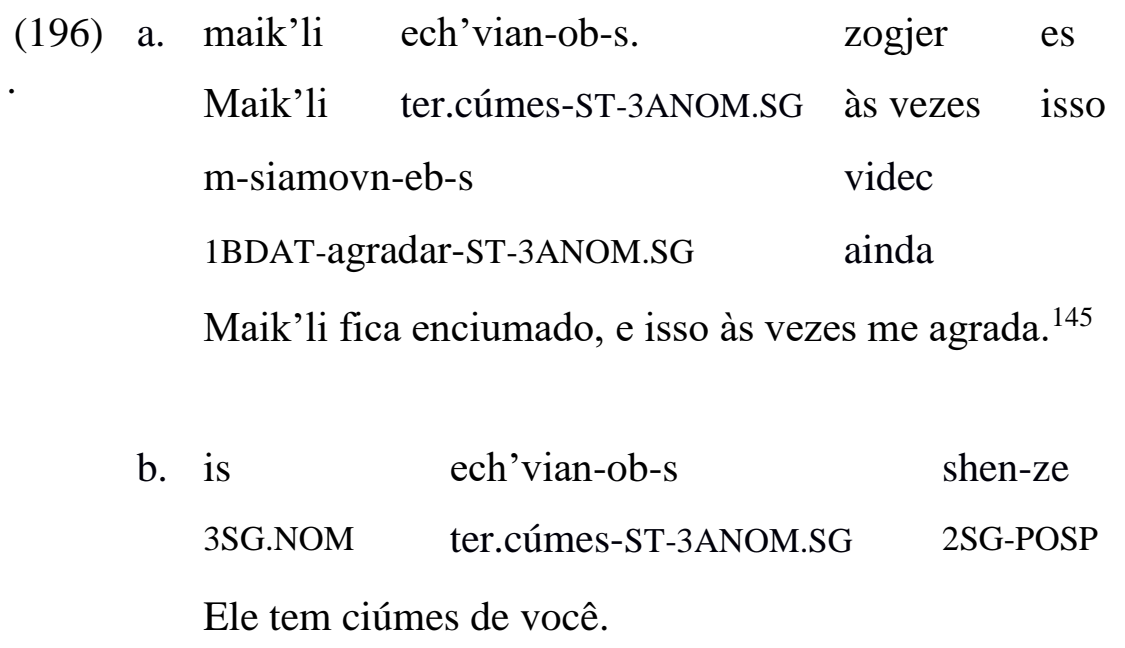

Nos exemplos acima, a primeira sentença mostra o verbo de Classe III ech 'vianobs 'ter ciúmes' sem o estímulo codificado; enquanto na segunda, o estímulo é codificado através da posposição -ze.

Situação semelhante se apresenta abaixo em que é ilustrado um verbo incoativo de Classe II ganacqen-d-eb-a 'ofender-se'. No primeiro exemplo, (197a), o estímulo não é codificado; no segundo, o estímulo é codificado através da posposição -ze:
(197) a. ga-nac'qend-a
am inpormaci-is
avt'or-i
PV-ofender.se-3ANOM.AOR essa informação-GEN
autor
O autor dessa informação se ofendeu.

\footnotetext{
${ }^{145}$ Exemplo retirado de: https://wol.jw.org/ka/wol/d/r20/lp-ge/1102011166
} 


$\begin{array}{lllll}\text { b. } \text { ga-v-nac'qend-i } & \text { am } & \text { dzma-ze } & \text { imis } & \text { gamo, } \\ \text { PV-1ANOM.-ofender.se-1ANOM.AOR } & \text { esse } & \text { irmão-POSP } & \text { 3SG.GEN } & \text { devido } \\ \text { rom } & \text { utanxmoeba } & \text { mo-gv-i-vid-a? } & \\ \text { que } & \text { desacordo.NOM } & \text { PV-2BDAT.PL-VPR-vir-3ANOM }\end{array}$

Eu fiquei ofendida com esse irmão devido a isso, por causa de nosso desentendimento? ${ }^{146}$

Outro exemplo de verbo de morfologia de Classe II em que o estímulo é codificado com a posposição -ze é o verbo braz-d-eb-a 'irritar-se':

$\begin{array}{llll}\text { me } & \text { ar } & \text { v-brazd-eb-i } & \text { adamian-eb-ze } \\ \text { 1SG.NOM } & \text { não } & \text { 1ANOM-irritar-ST-1ANOM } & \text { pessoa-ST-POSP } \\ \text { Eu não estou irritado com as pessoas. }{ }^{147} & \end{array}$

É interessante notar a relação entre 'assunto' da emoção (lembrando o conceito de Pesetsky (1995) de subject matter of emotion que mencionamos na seção 3.2) e a marcação do estímulo com a posposição -ze vista acima. Observe que essa posposição em seu sentido mais concreto marca a relação de 'sobre' em que há um contato de superfície no domínio físico. Essa extensão metafórica entre o domínio físico espacial e o sentido metafórico de assunto é observado em várias línguas como no inglês on e no português sobre.

Em tabasaran (língua leste-caucasiana), por exemplo, ocorre situação similar, em que o ablativo da série locativa - $k$-an, significando 'em, sobre (vertical)' é também usado metaforicamente com sentido de 'sobre, a respeito' (COMRIE \& POLINSKY, 1998).

Como discute Ferrando (1999) a respeito da preposição on do inglês, haveria no domínio físico como 'um vaso sobre a mesa' um esquema conceitual de suporte, em que um trajetor (um vaso) teria como suporte o marco (uma mesa). A extensão metafórica

\footnotetext{
${ }^{146}$ Exemplo retirado de: https://wol.jw.org/ka/wol/d/r20/lp-ge/2002605

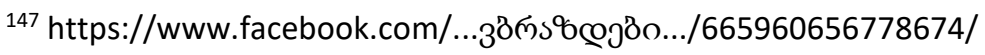


ao tema, tópico ou assunto estaria na metáfora de que tópicos ou assuntos seriam conceitualizados como partes de uma área ou base. Nessa perspectiva, 'eu fiz um comentário sobre isso' conceitualiza o assunto ou tópico a que se refere o comentário como uma base que lhe dá suporte. Como o autor menciona, vários verbos no inglês correspondem a esse padrão, tais como: comment on, agree on, write on, report on, consult on etc.

Assim, quando o estímulo é codificado no georgiano com a posposição $-z e, o$ estímulo parece ser concebido metaforicamente como o suporte sobre o qual a emoção sentida pelo experienciador jaz.

Em contraste com os casos acima, com verbos como i-ghl-eb-a 'cansar-se, estar cansado', quando o estímulo é codificado (199b), é o caso instrumental que é usado:

(199) a. me

$$
\text { da-v-i-ghal-e, da dac'ola m-i-nd-a }
$$

1SG.NOM PV-1ANOM-VPR-cansar-AOR e deitar 1BDAT-VPR-querer-3ANOM

Eu fiquei cansado e quero deitar. ${ }^{148}$

b. me da-v-i-ghal-e, chemi problem-eb-it 1SG.NOM PV-1ANOM-VPR-cansar-AOR meu problema-PL-INST

Eu me cansei dos meus problemas. ${ }^{149}$

Outros exemplos de verbos de morfologia de Classe II tendo o estímulo marcado com o caso instrumental é $i-t$ 'anj-eb-a 'sofrer de alguma coisa' e $t$ ' $k$ ' $b-e b-a$ 'aproveitar, ter prazer em algo, apreciar':

(200) a. ech'vianob-it i-t'anj-eb-a ciúmes.INST VPR-sofrer-ST-3ANOM

Ele está sofrendo de ciúmes. ${ }^{150}$

\footnotetext{
148 https://ka.glosbe.com/ka

149 https://wol.jw.org/ka/wol/d/r20/lp-ge/102008409

150 https://translate.academic.ru
} 
b. qoveltvis, roca cha-v-uvl-i xolme,

toda vez que PV-1ANOM-passar-1ANOM habitualmente

v-cherd-eb-i mati silamaz-it v-t'k'b-eb-i.

1ANOM-parar-ST-1ANOM deles beleza-INST 1ANOM-apreciar-ST-1ANOM

Toda vez que eu passava, eu parava e apreciava a beleza delas. ${ }^{151}$

Verbos de morfologia de Classe III também podem ser encontrados com o estímulo sendo codificado com o caso instrumental. É o caso do verbo amaqobs 'orgulhar-se':

(201) a. shen-it v-amaq-ob

2SG.INST 1ANOM-ter.orgulho-ST

Eu tenho orgulho de você. ${ }^{152}$

b. chemi kmr-it v-amaq-ob

meu marido-INST 1ANOM-ter.orgulho-ST

Eu tenho orgulho do meu marido. ${ }^{153}$

Como é possível recordar de nossa discussão na seção 5.3.1, não é somente no georgiano que o instrumental é usado em construções experienciais. Em koasati, alguns verbos transitivos marcados estativamente como stimayókpan 'amar', stificcákkin 'ter ciúmes' e sti'hawá:lon 'ter pena' foram derivados historicamente de outros verbos intransitivos de mesma raiz através do prefixo instrumental $s t-/ s^{-}$, dado esse que pode indicar que o instrumental pode ter sido utilizado para codificar um segundo participante oblíquo, com o tempo se gramaticalizando na estrutura desses verbos e perdendo o sentido de instrumental propriamente (KIMBALL, 1991).

De fato, o instrumental carrega, em seu sentido mais concreto através das línguas em que ocorre, o significado de 'por meio de, o instrumento por meio do qual

${ }^{151}$ Exemplo retirado de: https://wol.jw.org/ka/wol/d/r20/lp-ge/302008004

152 https://fanebi.com > nasris-gerlphrendi/

153 https://translate.academic.ru/ 
uma ação é realizada'. Esse sentido instrumental parece dar surgimento a sentidos mais abstratos e extensões metafóricas variadas.

Em línguas como o russo, por exemplo, o instrumental marca agentes da passiva. Em outras, como o português (assim como o instrumental em russo, cf. Janda (1993)), a mesma preposição que marca o instrumento 'ele o matou com uma faca' também pode ter significado comitativo 'ele saiu da casa com alguém (acompanhado de alguém)'.

Muitos verbos emocionais com o pronome -se em português, aliás, têm o estímulo marcado com a preposição 'com': 'irritar-se com', 'preocupar-se com', 'chatear-se com', 'assustar-se com', 'surpreender-se com', 'admirar-se com', alegrar-se com', etc. Já outros se utilizam da preposição 'de': 'orgulhar-se de', 'cansar-se de', 'arrepender-se de', 'envergonhar-se de', etc.

No caso do uso do instrumental (seja na forma de preposição ou caso gramatical) parece haver uma conceitualização de evento em que o estímulo é tido metaforicamente como o meio pelo qual o experienciador sente a emoção.

É interessante notar que, mesmo de formas diferentes, há uma coerência conceitual na forma como o estímulo é codificado através das línguas. Cabe relembrar da discussão feita na seção sobre DOM, em que discutimos as relações entre casos como o ablativo e genitivo e sua relação à noção de origem.

Não parece coincidência o fato de as línguas, mesmo com verbos ditos não causais (como verbos intransitivos, tais como incoativos), escolherem formas de codificarem o estímulo que trazem, ainda que de forma abstrata, sentidos que remetem ao fato de o estímulo ser o meio, a causa ou a origem da emoção despertada no experienciador, ou ainda alvo ou assunto dessa emoção.

Em todos esses casos, acreditamos, é salientado um aspecto diferente da conceitualização de eventos psicológicos nas línguas, dentre eles, por exemplo, o papel causal do estímulo, o estímulo como origem da emoção, o papel do experienciador como locus a partir do qual a emoção surge ou como o locus onde se dá emoção. Essa variedade, com argumentaremos no capítulo 7, decorre da característica de eventos experienciais serem bidirecionais, isto é, não haveria uma direcionalidade única como em eventos energéticos de transmissão de força, por exemplo.

Essa característica de eventos experienciais seria uma das motivações da variedade com que estímulo e experienciador são marcados nas línguas, ora como fontes de energia, ora como pontos finais energéticos. E um indício disso é a 
pervasividade com que encontramos essas codificações nas línguas e através das línguas.

Em georgiano, como vimos, além de construções transitivas, há construções experienciais intransitivas (usualmente médias ou incoativas com o experienciador como foco primário). Kemmer (1993), por exemplo, faz uma discussão sobre eventos emotivos marcados através da construção média nas línguas.

A autora parte de uma concepção próxima de Croft (1993), em que haveria duas relações através das quais experienciador e estímulo estariam ligados: a primeira, em que o experienciador dirigiria a sua atenção ao estímulo; e a segunda, em que o estímulo, ou alguma propriedade sua, causaria o evento mental no experienciador. Tanto em relação a eventos mentais de um participante quanto de dois participantes, o experienciador poderia ser o iniciador do evento na medida em que o evento se origina dentro da mente do experienciador, assim como o ponto final, já que o experienciador é afetado mentalmente.

A autora observa que nesses eventos, o estímulo pode ser ou não codificado, nos casos em que não é codificado (em eventos médios, por exemplo) a atenção é voltada completamente ao experienciador e ao surgimento da experiência.

Para Kemmer (1993), o que aproximaria eventos experienciais de eventos médios prototípicos (e possibilitaria a marcação média de eventos emocionais) seria justamente um grau de não distinguibilidade entre iniciador e ponto final, já que haveria essa possibilidade de conceitualizar a experiência como surgindo dentro da mente do experienciador e ao mesmo tempo sendo este afetado pela experiência.

De fato, talvez possa ser essa a razão de estímulos serem usualmente marcados perifrasticamente nesses casos (como da voz média), indicando a maior proeminência do experienciador e do surgimento da experiência.

Assim sendo, marcações mais intransitivas de eventos experienciais (mesmo que não formalmente marcados nas línguas, como através de uma marca de voz média) servem para focar um aspecto diferente da conceitualização de eventos emocionais.

Possivelmente daí a pervasividade com que encontramos essas construções em línguas de famílias variadas, como o georgiano acima, línguas românicas como o português (através do pronome -se), línguas eslavas como russo (através do clítico -sja), dentre outras.

Sobre o esloveno, por exemplo, Bedkowska-Kopczyk (2014) faz uma discussão a respeito dos verbos de emoção marcados através do clítico -se (equivalente ao -sja 
russo). A autora nota a diferença entre verbos imperfectivos e perfectivos com o clítico, sendo os últimos, eventos que expressariam transições emocionais inesperadas ou repentinas, por isso, mais incoativos, tais como vzradostit se 'alegrar-se', razjeziti se 'irritar-se'. Já os primeiros, seriam aqueles como botim se 'eu estou assustado' em que, segundo Bedkowska-Kopczyk (2014), envolveriam um processo em que o experienciador avaliaria a situação como ruim ou boa, gerando a emoção ou uma constatação de seu efeito positivo ou negativo.

Nesse ponto, a autora observa que esses verbos imperfectivos com o clítico se assemelhariam a verbos de emoção duradoura como ljubiti 'amar' e sovrazhiti 'odiar', na medida em que poderiam ser considerados mais como atitudes emocionais do que emoções espontâneas.

Essa análise da autora é similar aos resultados da análise que vimos de Grafmiller (2013) de verbos ObjExp do inglês, que argumentava que verbos construídos como mais estativos costumariam aparecer com estímulos mais abstratos e seriam emoções mais 'apreciativas', contrastando com emoções mais 'reativas', mais instantâneas e rápidas e, por isso, tendendo a serem construídas como emoções de mudança de estado.

Esse resultado também se assemelharia, como vimos através do estudo de Levin \& Grafmiller (2013), àquele encontrado em pares de verbos ObjExp e SubjExp como frighten e fear respectivamente, em que o último (levando em consideração o tipo de estímulo com o qual mais ocorreria no corpus) tenderia a marcar uma disposição em relação ao estímulo mais do que uma reação causal ao estímulo como marcada pelo primeiro.

Dessa forma, as diferenças observadas na marcação de eventos experienciais são indícios de que elementos distintos da conceitualização desses eventos estão sendo focalizados.

A diversidade de construções encontradas internamente nas línguas é rica e vai além das construções vistas até aqui, como médias, causativas ou indiretas, englobando construções perifrásticas com verbos leves, copulares ou com outros elementos.

Em português, como já vimos, há expressões causais como 'isso me preocupa/cansa/irrita'; perifrásticas causais 'isso me causa preocupação/medo/raiva', 'isso me deixou com raiva'; transferências metafóricas da emoção 'isso me dá raiva/medo/vontade'; metáforas locativas como 'havia um medo dentro de mim', 'isso nos enche de raiva/medo', 'estamos cheios de medo', 'eu estou cheio disso', etc. 
Além de outros processos metafóricos frequentes (cf. seção 2.2.7) como, por exemplo, a raiva muitas vezes sendo conceitualizada por meio de temperatura 'ele estava fervendo de raiva'; como loucura 'ele estava louco de raiva', como cegueira ou algo fora do controle do indivíduo 'ele estava cego de raiva', 'ele ficou fora de controle'; como um fluido 'ele despejou/derramou sua fúria', 'ele explodiu de raiva', etc (cf. o interessante estudo de Tutberidze (s/d) para uma comparação da expressão de raiva em georgiano, inglês e russo).

Há ainda, no português por exemplo, construções com o verbo 'estar' mais adjetivos ou substantivos, nesse último caso o substantivo denotando a emoção ocorrendo com a preposição 'com': 'eu estou nervoso' e 'eu estou com raiva' respectivamente; com o verbo 'ter': eu tenho medo/raiva; com o verbo 'ficar': 'eu fiquei triste', 'eu fiquei com medo'; com o verbo 'sentir/sentir-se': 'eu me senti envergonhado', 'eu sinto vergonha'.

Ainda mais interessante é perceber que muitas dessas construções se repetem através das línguas, por exemplo, Fedriani (2014, p.33) nota que em haussá, uma língua afro-asiática, há uma construção experiencial com uma marca comitativa introduzindo a emoção, à semelhança do português:

(202) ina da zafi

1SG COM calor

Eu estou com calor.

Um caso interessante é o verbo 'sentir/sentir-se' que foi introduzido no capítulo 5. Em georgiano, assim como no português, é possível usar o verbo 'sentir' com a emoção sentida como objeto (203b), assim como acompanhado com um adjetivo ou advérbio, neste último caso, em português, é usado o verbo em sua forma verbal média, i.e., com o pronome -se. Já em georgiano, a emoção permanece no caso adverbial e o verbo grdzn-ob 'sentir' de Classe III é acompanhado pelo reflexivo tav-s como no exemplo (203a) e (204): 
(203)

$\begin{array}{llll}\text { a. tav-s } & \text { dzalian } & \text { bednierad } & \text { v-grdzn-ob } \\ \text { REFL-DAT } & \text { muito } & \text { feliz } & \text { 1ANOM-sentir-ST }\end{array}$

Eu me sinto muito feliz. ${ }^{154}$

b. chven mravali ramis gamo v-grdzn-ob-t madliereba-s

1PL.NOM muito coisa.GEN devido 1ANOM-sentir-ST-PL gratidão-DAT

Nós sentimos gratidão por muitas coisas. ${ }^{155}$

(204) tav-s k'argad ver v-grdzn-ob

REFL-DAT bem não 1ANOM-sentir-ST

Eu não me sinto bem.

Nesses casos, é interessante notar que por mais que o georgiano não apresente uma marca de voz média própria, os verbos acima codificam, através da marca reflexiva tav-s, uma relação que se assemelha aos sentidos da voz média discutidos acima em relação a eventos experienciais, pois parece salientar o papel da experiência como a surgir ou residir dentro da mente do experienciador e sua afetação como objeto daquela experiência.

Outro caso que é frequentemente encontrado translinguisticamente é a de posse que discutimos na seção 5.3.4. Em georgiano, é também possível, como no português e outras línguas, se 'possuir' a emoção ou o estado físico:

$\begin{array}{llll}\text { (205) a. } & \text { dzaghl-eb-is } & \text { shishi } & \text { m-akv-s } \\ & \text { cachorro-PL-GEN } & \text { medo.NOM } & \text { 1BDAT-ter-3ANOM }\end{array}$

Eu tenho medo de cachorro.

b. sicxi m-akv-s

febre.NOM 1BDAT-ter-3ANOM

Eu tenho febre.

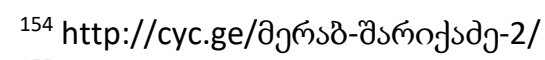

155 https://www.churchofjesuschrist.org/study/liahona/2016/11/ 
Outra forma também usada no georgiano é aquela que utiliza a cópula mais o particípio denotando a emoção, observe os exemplos:

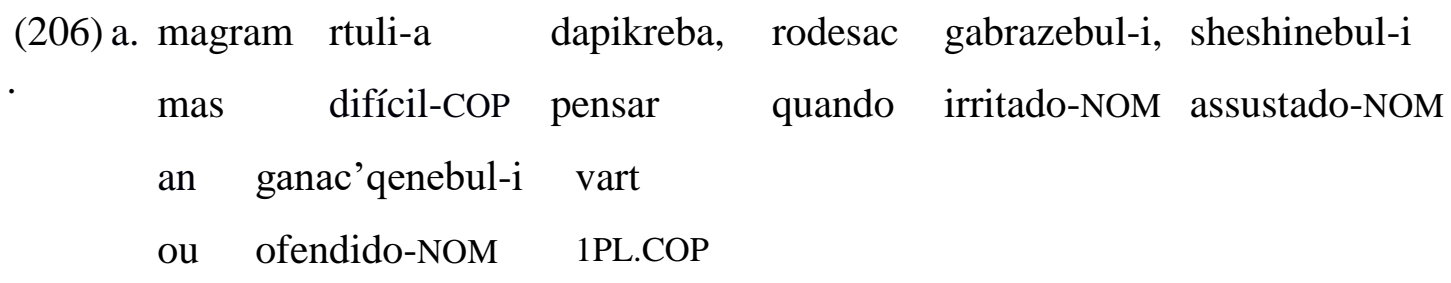

Mas é difícil pensar quando estamos irritados, assustados ou ofendidos. ${ }^{156}$

b. gabrazebul-i an imedgacruebul-i xar irritado-NOM ou frustrado-NOM 2SG.COP Você está irritado ou frustrado. ${ }^{157}$

Observe que nesses casos, também há a possibilidade de codificar o estímulo por meio de posposição:

(207) c'armoudgeneli-a, gabrazebul-i iqot mas-ze, vistvisac - improvável-COP irritado-NOM 2PL.COP 3SG-POSP por.quem locul-ob-t rezar-ST-PL

É improvável que ficassem irritados com ele, aquele por quem estão rezando. ${ }^{158}$

Por fim, como é possível ver pela tabela no início desta seção, construções com o experienciador na posição de objeto são também possíveis em georgiano, sendo os verbos usualmente marcados por meio de morfologia de Classe I, como pode ser visto

\footnotetext{
${ }^{156}$ Exemplo retirado de: https://wol.jw.org/ka/wol/d/r20/lp-ge/2008004

${ }^{157}$ Exemplo retirado de: $\mathrm{https} / / / \mathrm{wol} . j \mathrm{w} . \mathrm{org} / \mathrm{ka} / \mathrm{wol} / \mathrm{d} / \mathrm{r} 20 / \mathrm{lp}$-ge/102008088

${ }^{158}$ Exemplo retirado de: https://wol.jw.org/ka/wol/d/r20/lp-ge/2012846
} 
pelos exemplos dados acima dos verbos $a-c$ 'ux-eb-s 'incomodar, preocupar alguém' e $a$ ghel-eb-s 'preocupar alguém' e pelos exemplos abaixo:

\author{
(208) a. k'ac-i ga-a-braz-a up'asuxismgebloba-m \\ homem-NOM PV-VPR-irritar-3ANOM.AOR irresponsabilidade-ERG \\ Irresponsabilidade irritou o homem. (AMIRIDZE, s/d)
}
b. am ambeb-ma dzalian she-m-a-shin-a
essas histórias-ERG muito PV-1BDAT-VPR-assustar-3ANOM.AOR

Essas histórias me assustaram muito. ${ }^{159}$

Interessantemente, se lembrarmos da discussão na seção 5.5 a respeito de volicionalidade no georgiano, é possível notar que o caso ergativo tinha uma forte tendência a marcar volicionalidade e agentividade do participante, mesmo em casos em que prototipicamente o participante é tido como menos volitivo, caso de experienciadores em eventos experienciais, por exemplo. ${ }^{160}$

O que vemos nesses exemplos, no entanto, é o caso ergativo marcando participantes inanimados, o que mais uma vez indica que casos gramaticais, assim como outras categorias nas línguas não apresentam limites categóricos, mas sim padrões mais prototípicos, podendo haver diferentes sentidos a depender da situação e da significação

\footnotetext{
${ }^{159}$ Exemplo retirado de: https://wol.jw.org/ka/wol/d/r20/lp-ge/302011000

${ }^{160}$ É pertinente trazer o exemplo a seguir de Harris (1981). O verbo ilustrado abaixo apresenta marcação variável: enquanto a sentença em (a) constitui o padrão considerado normativo, i.e., o verbo de morfologia de Classe III tem o sujeito marcado com o caso ergativo no aoristo; em (b), temos o uso coloquial em que o sujeito é marcado com o caso nominativo:
}
a. macivri-dan c'qal-ma i-c'vet-a
geladeira-POSP água-ERG VPR-pingar-3ANOM.AOR

A água pingou da geladeira.
b. macivri-dan c'qal-i i-c'vet-a
geladeira-POSP água-NOM VPR-pingar-3ANOM.AOR

A água pingou da geladeira.

Interessantemente, segundo Harris (1981), ao ter apresentado as duas sentenças a um falante, este lhe respondeu que embora soubesse que a sentença em (a) seria a 'correta', soava-lhe estranha, parecendo que a água estava pingando 'de propósito' (como se tivesse volicionalidade). 
dada pelos falantes. Isso não quer dizer, naturalmente, que tudo é possível em determinada língua, o próprio uso, arraigamento e convencionalidade restringem em certa medida as possibilidades.

Outro dado importante para nossa argumentação advindo da variedade de construções discutidas nesta seção é a observação de que certas formas de se construir eventos experienciais são pervasivas o bastante nas línguas para servirem de indício para entender a forma como conceitualizamos esses eventos.

Essa discussão será feita mais detalhadamente no capítulo 7.

\subsection{A análise de Maldonado (2002) e relação com outras construções com} dativos

Em outros momentos desta tese, já tivemos a oportunidade de discutir outras construções que ocorrem com dativos nas línguas além de eventos experienciais emocionais, físicos, etc., tais como de posse e modalidade. Nesta seção, discutiremos outras mais sem, no entanto, o intento de sermos exaustivos, tendo o propósito de dar uma visão geral que se alinhará à nossa análise das construções dativas experienciais sob foco, de forma a mostrar que essas construções com dativos têm pontos de sentido em comum, daí a semelhança em codificação.

Diversos estudos dentro da Linguística Cognitiva focaram o uso do dativo em determinadas línguas, buscando explicar esses usos de forma a considerar a natureza polissêmica do caso gramatical.

Maldonado (2002), por exemplo, analisa as construções com dativos no espanhol sob a perspectiva da Gramática Cognitiva de Langacker. Sua análise é interessante, pois mostra a relação entre construções com dativos, tais como as de transferência, de posse externa e experienciais (como emocionais), utilizando-se de conceitos como domínio (dominion, cf. seção 5.3.4.1), afetação e grau de atividade do experienciador.

Assim como Janda (1993), que analisa as construções dativas no tcheco e russo, Maldonado assume que as construções dativas são estendidas a partir do esquema de transferência (abaixo), é desse esquema, e tendo como base a representação esquemática 
do experienciador, é que outras construções dativas se baseariam, formando um network de significados relacionados.

Tanto a análise de Maldonado (2002) quanto de Janda (1993), fundamentalmente, levam em consideração que há polissemia nos usos do dativo e que os diferentes construals estão relacionados em torno de um protótipo, formando, assim, uma rede de construções relacionadas de forma tanto mais central ao protótipo quanto de forma mais periférica.

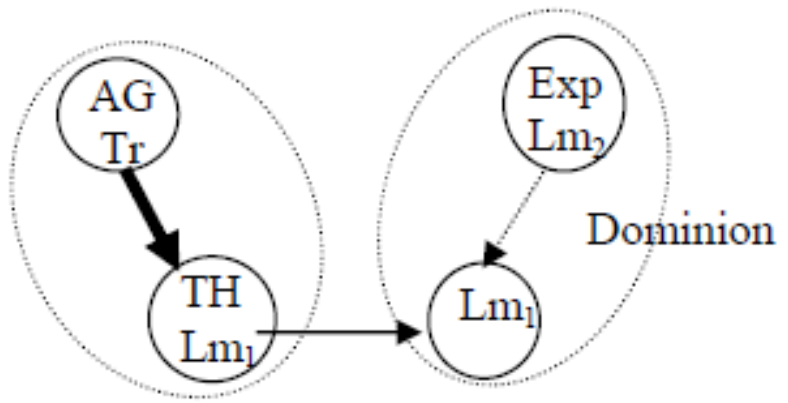

Figura 8: Esquema de transferência de verbos como 'dar' (MALDONADO, 2002)

A figura 8 mostra o esquema de transferência de verbos como 'dar' que envolvem um processo em que três participantes são perfilados. No esquema, há uma transferência de energia do trajetor, o agente, para o tema, o marco ( $\operatorname{lm}_{1}$ na figura) que se move do domínio do agente para o domínio do experienciador ( $\operatorname{lm}_{2}$ na figura). $\mathrm{O}$ experienciador é o último participante na cadeia de ação, não tendo contato direto com o agente, dessa forma, isso implicaria uma relação entre agente e experienciador mais distante, e mais ativa do experienciador, do que a relação entre agente e paciente, em que há contato direto e o paciente é passivamente afetado pela ação direta do agente.

Como argumenta Janda (1993), no esquema de transferência, sendo um verbo como 'dar' prototípico, o objeto indireto constituiria o protótipo do dativo em línguas como o tcheco. Consequentemente, o experienciador, um arquétipo conceitual, seria o protótipo tanto para o objeto indireto quanto para o dativo (LANGACKER, 2008, p.392; MALDONADO, 2002, p. 8).

Além de verbos como 'dar' (em georgiano (209)), outros verbos também instanciariam o esquema de transferência nas línguas, tais como o verbo em georgiano ugzavis 'enviar' em (210), em que o recipiente é marcado com o caso dativo; e verbos de comunicação, tais como 'contar' no exemplo do tcheco em (211): 


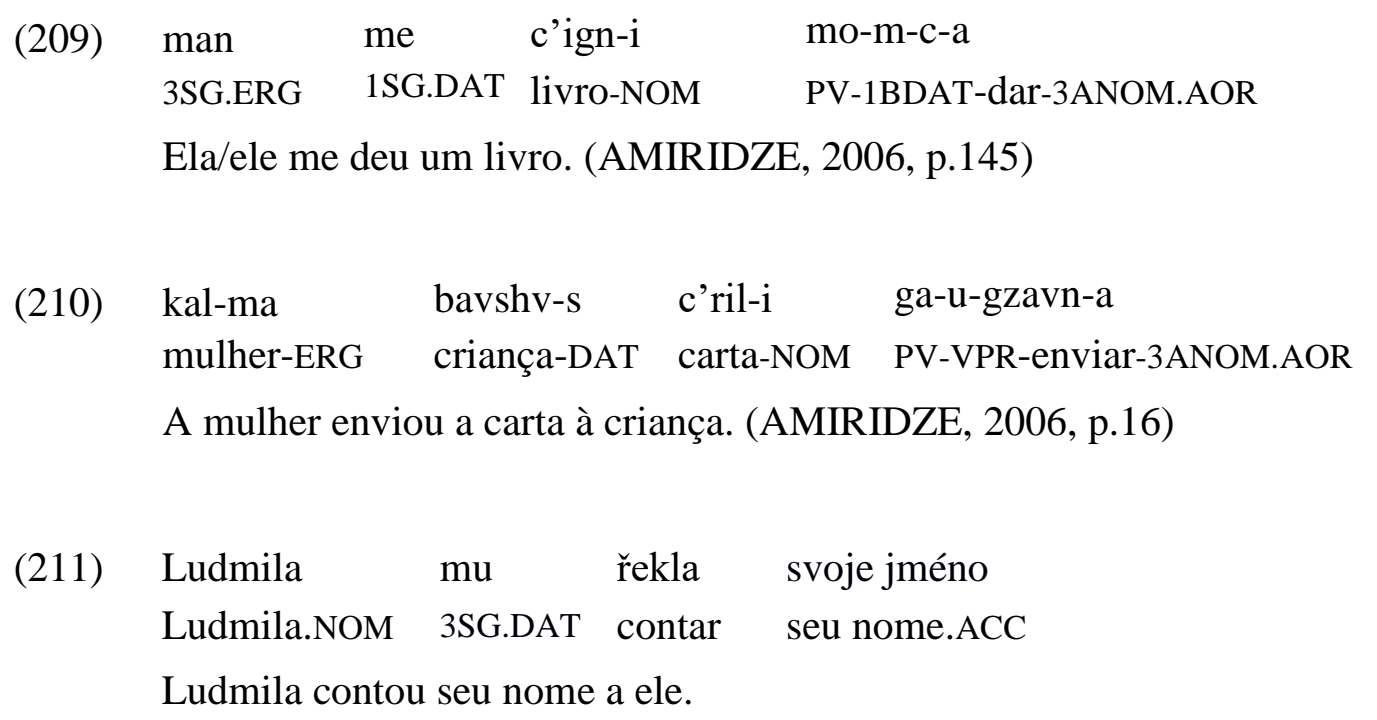

Interessantemente, no georgiano, verbos como 'dar, vender, escrever, dirigir-se, trazer' são marcados com o preverbo $-m o$ ou $-m i$ que diacronicamente tem origem espacial na língua, marcando movimento (-mo para alvo aproximado (atualmente sendo usado com primeira e segunda pessoa com esses verbos) e -mi para distante (com terceira pessoa) (AMIRIDZE, 2006)).

Em georgiano, como foi visto na seção 4.5, as vogais pré-radicais, em sua função de versão, servem para marcar um participante extra à estrutura verbal, dentre eles, beneficiários e objetos indiretos em verbos intransitivos, além de também marcarem experienciadores e possuidores em alguns casos, havendo, dessa forma, uma relação próxima entre as vogais pré-radicais (e os sentidos de versão verbal que marca) e objeto indiretos.

De fato, como nota Janda (1993, p.48), os exemplos abaixo começam gradualmente a transitar de recipiente a um sentido mais benefactivo do dativo, visto de forma mais contundente em (212c).

$\begin{array}{llllll}\text { (212) a. } & \text { Ludmila } & \text { mu } & \text { ukázala } & \text { cestu } & \text { domu } \\ & \text { Ludmila.NOM } & \text { 3SG.DAT } & \text { mostrar } & \text { caminho.ACC } & \text { casa }\end{array}$ Ludmila mostrou para ele o caminho de casa. 
b. Ludmila mu koupila klobouk

Ludmila.NOM 3SG.DAT comprar chapéu.ACC

Ludmila comprou para ele um chapéu.

c. Ludmila mu koupila kaši

Ludmila.NOM 3SG.DAT cozinhar kaše.ACC

Ludmila cozinhou kaše para ele.

Para explicar a marcação dativa em comum dessas diversas construções (verbos de transferência, de posse, experienciadores, etc.) Maldonado se vale da noção de atividade.

Para Maldonado (2002), experienciadores (no artigo, sendo tomado como arquétipo conceitual do dativo) seriam participantes ativos em seu domínio, atividade nesse caso é uma noção relativa, o experienciador é mais ativo do que o paciente, mas menos ativo do que o agente. Domínio (dominion) se refere a uma área virtual em que um participante interage física ou mentalmente com outro participante, importantemente, para Maldonado (2002), experienciadores são participantes salientes, pois agem como pontos de referência para localizar outros participantes menos salientes dentro de seu domínio. ${ }^{161}$

Um caso em questão, descrito por Maldonado, são as construções dativas envolvendo posse. A noção de domínio na construção dativa serviria para relacionar duas entidades assimétricas, e frequentemente a presença de duas entidades assimétricas no mesmo domínio indicaria algum tipo de relação de posse, já que uma relação de posse é essencialmente assimétrica (CROFT, 1993; LANGACKER, 2008; MALDONADO, 2002).

O dativo, sendo mais ativo, seria um participante mais saliente e, por isso, o possuidor, servindo como ponto de referência para localizar o participante menos saliente e mais passivo, i.e., o tema e possuído. A afetação ocorreria como consequência da posse como no exemplo de posse inalienável a seguir (alguns casos similares exemplificados na seção 5.3.4):

${ }^{161}$ Domínio, em inglês dominion, que é usado por Langacker (cf. seção 5.3.4.1) para se referir a uma região conceitual em que uma entidade atua como ponto de referência (e estabelece contato mental com outra), deve ser distinguido da noção de domain na GC (cf. seção 2.2.4) que, por sua vez, se refere a uma estrutura conceitual que serve como base através da qual um conceito é perfilado. 
Experienciadores são ativos na medida em que estabelecem contato abstrato ou concreto com outra entidade ou com o resultado de uma ação, reagindo a esse contato. Dessa forma, decorre de sua atividade a afetação do experienciador, i.e., experienciadores são participantes afetados na medida em que reagem ou experienciam sensações físicas ou emocionais decorrentes desse contato.

Por essa razão, o tipo de afetação associada ao experienciador é diferente da afetação mais passiva sofrida pelo paciente, sendo, em contraste a essa última, uma afetação mais ativa em que há algum tipo de reação ou interação por parte do experienciador.

No espanhol, o dativo é codificado pelo clítico le(s) ligado ao sintagma preposicional introduzido pela preposição $a$. Os clíticos acusativos e dativos no espanhol possuem a mesma forma na primeira e segunda pessoa (me, nos, te) e somente podem ser distinguidos na terceira pessoa, $l e(s)$ para o dativo e $l o(s)$ para o acusativo (MALDONADO, 2002).

$\mathrm{Na}$ análise do autor, o clítico teria a função de perfilar uma forma de afetação do experienciador, estabelecendo um vínculo mais próximo entre o objeto indireto e o agente.

Para Maldonado, todas as construções dativas envolveriam um participante, o experienciador, sendo afetado, e isso implica algum tipo de contato ou interação dentro do domínio do experienciador. Dessa forma, essa caracterização estaria presente de forma esquemática nas extensões desse protótipo. O modo, no entanto, como essa afetação se dá difere em cada construção.

Assim, diferentes elaborações e extensões são esperadas a partir do esquema de transferência, de modo que aspectos distintos podem ser perfilados.

Maldonado faz ainda uma distinção entre dativos on-stage e off-stage. Os primeiros são os dativos objetivos, em que o dativo está localizado dentro da cena e o conceitualizador descreve ou observa o evento off-stage, fora da cena e sem 
envolvimento emocional. Já os segundos, os dativos subjetivos, o conceitualizador é incorporado ao evento, e o dativo torna-se mais subjetivo na medida em que há um envolvimento ou avaliação por parte do conceitualizador, compartilhando a visão do participante afetado.

Dentre os dativos subjetivos, Maldonado distingue dois tipos no espanhol: sympathetic dative (SYD), o dativo solidário; e setting dative (SD), o dativo do setting. No primeiro, o conceitualizador off-stage é incorporado ao evento, mas não participa dele diretamente, compartilhando a afetação do participante dativo, já que todo o evento é conceitualizado dentro do domínio do conceitualizador (frequentemente, estabelecendo uma relação de posse com um participante do evento).

No segundo, o participante dativo está localizado no setting, o cenário on-stage onde o evento é conceitualizado. Além de estarem localizados em locais diferentes, o SD se distinguiria do SYD no grau de atividade, sendo mais ativo do que o SYD, por estar mais envolvido no evento, e menos ativo do que um participante dativo central.

Os exemplos abaixo contrastam os dois tipos:

(214) a. Me le arruinaron la vida a mi hija. (SYD)

Me arruinaram a vida da minha filha

b. Adrián me le arruinó la fiesta a Valeria. (SYD)

Adrian me arruinou a festa da Valéria.

c. Se me murió en las manos. (SD)

Ele me morreu nas mãos.

d. Me castigaron al niño. (SD)

Eles me puniram a criança.

(MALDONADO, 2002)

Em (214c e d), o espaço emocional e o locativo são unidos, pois o participante dativo é construído como o cenário onde o evento ocorre, havendo um vínculo de afetação entre o dativo e o tema. Em (214a e b), o conceitualizador, o falante de 
primeira pessoa, é incorporado ao evento, compartilhando a afetação com um participante on-stage, como 'filha'.

Exemplos de dativos subjetivos nas línguas não são difíceis de se encontrar e sua descrição remonta a línguas como latim.

Nas gramáticas tradicionais latinas, por exemplo, costumava-se distinguir diversos tipos de dativos (cf. Pinkster (2015)): o dativo de interesse (commodi/incommodi 'vantagem/desvantagem'), chamado por vezes de dativo de referência e assemelhando-se a beneficiários em alguns momentos, como no exemplo do português 'Maria lhe cozinhou um prato especial', significando 'Maria cozinhou um prato especial para ele'; o dativo sympatheticus (lembrando os casos de SD do espanhol vistos acima), envolvendo a noção de posse e afetação daquele argumento, como no português 'Me roubaram o carro', em sentido mais neutro 'Roubaram meu carro'; e o dativo ethicus (similar aos casos de SYD do espanhol acima), indicando envolvimento daquele que fala, sendo normalmente encontrado em primeira pessoa (em algumas línguas, também na segunda pessoa) como nos exemplos do português 'Esse bebê não me dorme', 'Não vai me cair aí!'.

Como Gurevich (2006) menciona, alguns usos das vogais pré-radicais se assemelhariam aos descritos para o latim acima, principalmente em relação à marcação de posse e afetação do participante dativo.

De fato, é possível dizer que exemplos tais como o ilustrado abaixo do georgiano (traduzidos frequentemente para o inglês através da expresão com a preposição on 'He died on me', denotando mais afetação) não codificariam apenas uma relação de posse, mas também algum tipo de afetação por parte do participante dativo como nos casos apontados acima do espanhol e português:

$\begin{array}{llll}\text { (215) gasul } & \text { c'els } & \text { bebia } & \text { mo-m-i-k'vd-a } \\ \text { passado } & \text { ano } & \text { avó } & \text { PV-1BDAT-VPR-morrer-AOR }\end{array}$

Ano passado minha avó morreu. (ARONSON, 1990, 242)

Janda também nota para o tcheco que o uso do dativo em casos similares normalmente indica uma relação de posse e também afetação que se dá através da posse, como no exemplo abaixo: 


$$
\begin{array}{llll}
\text { Aleš } & \text { nám } & \text { naboural } & \text { auto } \\
\text { Aleš.NOM } & \text { 1PL.DAT } & \text { quebrou } & \text { carro.ACC }
\end{array}
$$

Aleš nos quebrou o carro (Alesh quebrou nosso carro). (JANDA, 1993, p. 58)

Como a autora diz, a posse age como um veículo para afetar o participante dativo (no caso acima o participante é afetado negativamente), sendo uma expressão com um valor diferente de outras expressões de posse como o caso genitivo no tcheco ou adjetivos possessivos.

Em casos de posse inalienável, por exemplo, comum com dativos, Janda (1993) observa que o uso do genitivo ou possessivo é estranha ou quase inaceitável, observe:

$\begin{array}{lll}\text { zlomil } & \text { jí } & \text { ruku } \\ \text { quebrou } & \text { 3SG.DAT } & \text { braço.ACC }\end{array}$

Ele quebrou o braço dela. (Lit.: Ele lhe quebrou o braço) (JANDA, 1993, p. 87)

A substituição do dativo jí pelo genitivo její, segundo a autora, resultaria em uma sentença estranha em que seu referente pareceria alienado de seu próprio braço, como se o braço tivesse sido cortado antes do evento presente.

Passando aos dativos que Maldonado chama de objetivos, o autor cita os casos prototípicos que envolvem transferência de algum objeto do agente ao experienciador como os verbos citados acima dar, enviar, e também verbos de transferência abstrata, como verbos de comunicação, decir 'dizer', pedir, etc. ${ }^{162}$

Alguns verbos de emoção que possuem um objeto indireto como argumento (e.g. desear, admirar, envidiar, elogiar) também elaborariam o esquema de transferência, em que o sujeito projetaria emoções, sentimentos e pensamentos no alvo, o experienciador.

162 Interessantemente, já foi observado na literatura que expressões designando o processo de comunicação, em diversas línguas, refletem a metáfora do conduto, em que palavras são containers de ideias ou pensamentos e são transferidos do falante ao interlocutor através de um conduto (cf. LANGACKER, 1987). 
No exemplo em (218a), suerte 'sorte' é conceitualizada como sendo transferida do sujeito ao experienciador:

(218) a. Le deseo suerte

Eu lhe desejo sorte.

b. Le envidio tanta felicidad.

Eu o invejo por tanta felicidade.

(MALDONADO, 2002)

Em (218b), 'felicidade' é conceitualizada como uma propriedade que é trazida para o domínio do experienciador, dessa forma, o participante dativo age como ponto de referência para a localização dessa propriedade.

A caracterização do clítico dativo le como a perfilar a afetação do participante, e que está relacionada ao grau de atividade do experienciador, é usada por Maldonado para descrever a diferença de verbos que podem aparecer tanto com o clítico acusativo lo quanto com o dativo, os exemplos abaixo ilustram verbos psíquicos que apresentam essa variação como interesar, atraer, molestar, etc.:

(219) a. Los niños lo molestaron.

As crianças o incomodaram.

b. Los niños le molestan.

As crianças o irritam.

(MALDONADO, 2002)

De acordo com o autor, o participante acusativo em (219a) apenas sofreria a ação das crianças, enquanto o dativo em (219b) teria um maior grau de atividade, reagindo à ação e demonstrando sua irritabilidade. 
Langacker (2008) também nota o maior grau de atividade do participante dativo com certos verbos intransitivos com dois participantes como, no francês, obéir 'obedecer', convenir 'convir', aider 'ajudar', parler 'falar', répondre 'responder' ${ }^{163}$

Haspelmath (2001, p.59) chama esses verbos de 'verbos de interação', com base no estudo de Blume (1998) do polonês, alemão e húngaro. Para Haspelmath (2001), esses verbos teriam possivelmente uma marcação diferenciada, i.e., não canônica, devido ao segundo participante não ser um paciente típico, apresentando características de agentes.

Maldonado (2002) também distingue verbos mentais ativos e hiperativos no espanhol. No primeiro grupo há verbos como preocupar, admirar, complacer 'agradar', emocionar, dentre outros. Segundo o autor, o argumento dativo desses verbos seria complemento de construções intransitivas, o que contrastaria com o uso desses verbos com complementos acusativos que teriam um grau maior de transitividade, pois o objeto seria diretamente afetado pela ação do sujeito. Já o dativo seria mais ativo e participativo, tendo mais controle sobre a mudança emocional.

Os exemplos abaixo ilustram a diferença com o verbo preocupar em seu uso com um complemento dativo em (220a) e seu uso com um complemento acusativo em (220b).

(220) a. Lo importante para él es su compaña y no le preocupa lo demás.

O importante para ele é sua campanha e não o preocupa o restante.

b. La caída de la bolsa lo preocupó enormemente.

A queda da bolsa o preocupou enormemente.

(MALDONADO, 2002)

\footnotetext{
163 Pinkster (2015) também nota que no latim certas verbos teriam seu segundo argumento marcado com o caso dativo, observando alguns agrupamentos semânticos tais como: verbos de ajuda, cuidado (e opostos); verbos de agradar e ameaçar; verbos de obedecer, servir, comandar; e verbos de aproximação.
} 
Em contraste com os verbos psicológicos ativos, os verbos psicológicos hiperativos, como chamados pelo autor, como gustar, repugnar, encantar, etc., só podem ocorrer com complementos dativos:

(221) a. A Adrián le encantó la película.

Adrián adorou o filme.

(MALDONADO, 2002)

Maldonado nota que, nesses verbos, o dativo compartilha algumas propriedades com sujeitos agentivos (por exemplo, controle de gerúndio).

Para o autor, a razão é que além de o experienciador ter contato mental ou emocional com o evento, também projetaria uma reação controlada, havendo um julgamento ativo e um maior controle por parte do experienciador, o que o aproximaria de sujeitos agentivos. Maldonado, no entanto, argumenta que o experienciador dativo não poderia ser considerado um sujeito pleno no espanhol, pois o evento seria iniciado no domínio alvo, e sujeitos no espanhol teriam que estar no domínio fonte. ${ }^{164}$

O esquema dos verbos hiperativos, sendo uma extensão mais periférica do esquema de transferência, mantém algumas de suas propriedades em sua base:

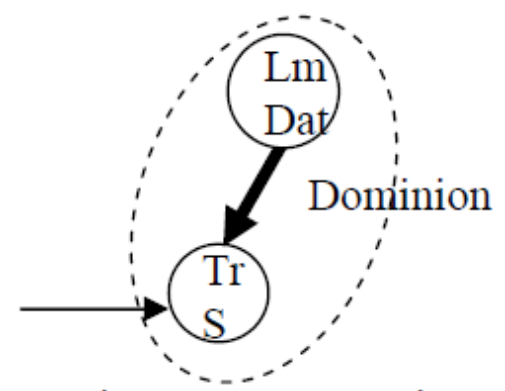

Figura 9: Esquema de verbos hiperativos como gustar (MALDONADO, 2002)

164 Em Langacker (1991), domínio fonte (source domain) e domínio alvo (target domain) fazem referência à cadeia de ação, o domínio fonte é o lugar onde a energia se origina e o domínio alvo é aquele onde a energia é consumida. 
Na figura 9, o foco é o domínio alvo (tornando-se irrelevante a força iniciadora de um agente), e onde um sujeito temático entra no domínio do experienciador.

A análise de Maldonado é particularmente interessante, pois aponta para semelhanças conceituais entre construções dativas distintas (mas que frequentemente se agrupam nas línguas através da codificação através do dativo), tais como a afetação do participante dativo, seu maior grau de atividade na medida em que faz contato mental com o estímulo, reagindo mais ativamente a ele dentro de seu domínio (aproximando-se de recipientes e alvos em eventos de transferência).

Como já comentamos anteriormente em diversos momentos, não é raro nas línguas encontrarmos construções em que experienciadores são conceitualizados através de metáforas espaciais, como 'locais', onde a emoção ou sensação física acontece, ou como recipientes, de forma a receber a emoção.

De fato, parece haver um caminho conceitual em que inicialmente a força causadora do evento experiencial é atenuada, focando-se, em verbos psicológicos, no domínio alvo, ou seja, a porção em que o participante dativo faz contato com o participante que entra em seu domínio.

Aspectos importantes, como visto, são também a afetação do experienciador e sua saliência conceitual como pontos de referência para localizar uma outra entidade ou evento. Dessa forma, experienciadores são participantes afetados e são ativos na medida em que estabelecem contato mental e interagem com outra entidade. Para Maldonado, no entanto, o participante experienciador dativo não agiria como a força iniciadora do evento por estar no domínio alvo.

A respeito desse último ponto, por argumentarmos que eventos experienciais são bidirecionais, acreditamos que experienciadores dativos podem ser conceitualizados sim como fontes de energia, isto é, a emoção ou sensação física como a surgir a partir deles (cf. discussão no capítulo 7). Dessa forma, dada sua tendência a serem participantes salientes conceitualmente, como participantes ativos e animados, há a possibilidade de esses participantes dativos serem conceitualizados como foco primário. Assim, um próximo passo provável desse caminho conceitual seria aquele em que o experienciador dativo seria conceitualizado como fonte de energia e, como possível consequência, como foco primário nas línguas, como acreditamos ser o caso de línguas como o georgiano e, também, o espanhol, gerando consequências estruturais, principalmente, no caso de verbos hiperativos no espanhol, como chama Maldonado acima. 


\subsection{A relação próxima entre dativos e locativos}

Nesta seção discutiremos a relação entre a marcação de experienciadores como recipiente/alvo e sua marcação por meio de casos locativos (ou mesmo preposições/posposições a depender da língua). Veremos que há uma relação próxima entre dativos e locativos.

Um caso em questão é o das línguas leste-caucasianas (sendo a maior parte morfologicamente ergativa) que apresentam uma marcação não canônica de verbos experienciais, variando, a depender da língua e predicado, entre marcar o experienciador com o caso dativo, afetivo (um caso usado especialmente com verbos experienciais nessas línguas) e, alguns casos, com casos locativos (cf. COMRIE \& van den BERG, 2006; GANENKOV, 2006):

A língua bagvalal, por exemplo, marca o experienciador de verbos emocionais (amar/querer) com o caso dativo, enquanto outros verbos experienciais, como de percepção e cognição e verbos de atividade não intencional, são marcados com o caso afetivo:

$\begin{array}{llll}\text { hebo } & \text { bac'a } & \text { q'ochamo } & \text { ek'wa } \\ \text { o.que } & \text { 2SG.DAT } & \text { querer } & \text { ser }\end{array}$

O que você quer? (COMRIE \& van den BERG, 2006, p.133)

(223) Sali-ba bac'a $\quad$ hán $^{\mathrm{n}}$
Ali-AFF lobo.ABS ver.PAST
Ali viu um lobo. (COMRIE \& van den BERG, 2006, p.133)

Já a língua avar difere de bagvalal apenas na marcação de verbos experienciais de percepção, cognição e verbos de atividade não intencional, em que é utilizado um caso locativo em vez do afetivo (no exemplo abaixo, o superessivo): 
(224)

$\begin{array}{llll}\text { di-da } & \text { goh } & \text { bihuleb } & \text { bugo } \\ \text { 1SG-SUP } & \text { montanha.ABS } & \text { ver.PRES } & \text { COP }\end{array}$

Eu vi a montanha. (COMRIE \& van den BERG, 2006, p.133)

A língua godoberi tem marcação similar à de bagvalal, com exceção do verbo de cognição 'saber', em que apresenta um caso locativo (o contessivo):

$\begin{array}{lll}\text { di-da } & \text { Sali } & \text { wuch:a } \\ \text { 1SG-CONT } & \text { Ali.ABS } & \text { entender.PAST }\end{array}$

Eu entendo Ali. (COMRIE \& van den BERG, 2006, p.135)

Em contraste, no caso da língua tsakhur, são os verbos de atividade não intencional que são marcados com um caso locativo (abaixo, o adelativo), sendo o resto semelhante à língua bagvalal, i.e., dativo para verbos emocionais, e caso afetivo para verbos de percepção e cognição:

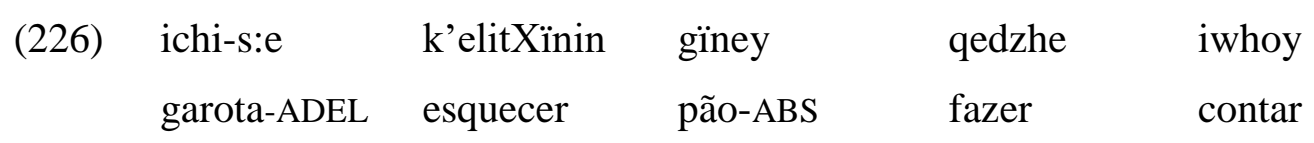

A garota esqueceu que eles disseram a ela para fazer o pão. (COMRIE \& van den BERG, 2006, p.136)

O sistema de casos gramaticais locativos das línguas leste-caucasianas é complexo e não nos aprofundaremos nas diferenças de significado de cada combinação (em uma língua como tabasaran, por exemplo, há em torno de 8 séries de marcas locativas que podem ser distinguidas com base na noção de orientação espacial (como 'em', 'atrás', ‘debaixo', 'perto', etc.), a essas marcas ainda podem ser combinadas outras três que indicam o tipo de movimento (alativo, essivo e ablativo), cf. Comrie \& van den Berg (2006)). 
Dois pontos, no entanto, são importantes notar para nossa argumentação. O primeiro ponto é acerca da origem do caso afetivo nas línguas leste-caucasianas. Segundo Ganenkov (2006), para alguns ramos da família, é possível traçar a origem diacrônica do caso, em especial nas línguas ândicas, em que se observa sua origem espacial/locativa. O autor observa que nessas línguas, o caso afetivo tem reflexo no afixo alativo *-CL-O em proto-ândico (' $\mathrm{CL}$ ' significa a concordância de classe). Atualmente, as línguas ândicas perderam o sentido original alativo do caso afetivo, com a exceção da língua bagvalal, que ainda preserva em algumas formações o sentido locativo do caso.

O segundo ponto é a relação entre o caso dativo e casos locativos (ou mesmo preposições/posposições) nas línguas.

Como discutem van Belle \& van Langendonck (1996), dois sentidos básicos relacionados ao dativo poderiam ser divisados: o de alvo (goal), conectado ao evento de transferência, e de 'parte interessada'; quando esses dois papéis são unidos, resultaria no 'recipiente' típico que apareceria com verbos prototípicos como 'dar'.

A pergunta que se faz, no entanto, é até que ponto esses sentidos do dativo (usualmente presentes na caracterização do objeto indireto) seriam de fato distintos de sentidos mais locativos codificados por casos locativos? Comrie \& Polinsky (1998), tomando as línguas leste-caucasianas como centro, discute alguns pontos em que seria difícil fazer uma separação entre uma função mais gramatical (em algumas línguas, inclusive, gerando concordância no verbo) do dativo e sentidos considerados mais locativos (normalmente codificados por casos locativos em línguas leste-caucasianas), concluindo que em muitos casos o dativo seria um caso limítrofe. ${ }^{165}$

Em tabasaran, por exemplo, Comrie nota que, por um lado, o dativo (em vez dos casos locativos) é frequentemente usado para marcar 'movimento em direção', além de poder ser combinado com o sufixo - $d i$ que usualmente só ocorre com casos locativos. Por outro lado, o dativo tem também características de casos gramaticais (como concordância no verbo), além do mais, o dativo aparece marcando o experienciador em eventos emocionais e não intencionais (acidentais) em tabasaran.

Outro dado interessante vindo da língua tsez é que tanto o dativo quanto um caso locativo (o essivo) podem ser usados para marcar o recipiente do verbo 'dar', cada qual

\footnotetext{
165 Comrie \& Polinsky (1998), citando o estudo de Blake (1994), nota que o dativo românico em a (como no espanhol, italiano e francês) expressaria tanto o objeto indireto quanto sentidos locais associados à preposição ad do latim (como direção), sendo um exemplo de dativo derivado de um locativo.
} 
trazendo uma nuance de significado diferente. No exemplo (227a), com o recipiente marcado com o dativo, há o significado de que a posse do objeto é permanente; enquanto no segundo exemplo (227b), com o recipiente marcado com o caso locativo, há o sentido de que a posse do objeto pelo recipiente é temporária:

a. uzh-a kidbe-r eLu teLsi

garoto-ERG garota-DAT mirtilo dar

O garoto deu mirtilos à garota (para manter). (COMRIE \& POLINSKY, 1998, p.111)

b. uzh-a kidbe-q eLu teLsi

garoto-ERG garota-ESS mirtilo dar

O garoto deu mirtilos à garota (por um tempo). (COMRIE \& POLINSKY, 1998, p.111)

Esse dado é importante, pois mostra um uso do caso locativo em uma função (i.e., como recipiente do verbo 'dar') que normalmente é considerada prototípica do caso dativo.

O que pode indicar, assim, a dificuldade de se estabelecer um limite preciso entre os significados do caso dativo e de casos locativos propriamente, havendo o que parece um campo de convergência entre eles, o dativo usualmente estando numa região limítrofe, tanto em termos de significados que envolvem o domínio espacial, quanto em termos de proeminência, já que se costuma observar que o dativo pode ter em algumas línguas (mas não todas) comportamentos sintáticos de participantes proeminentes (como concordância no verbo como em georgiano), comportamento normalmente não visto nessas línguas com participantes marcados perifericamente (como locativos e preposições/posposições).

Um último dado a se notar é que não raro dativos podem derivar de casos locativos (cf. também nota 165 acima). É o caso da língua karata, notado por Ganenkov (2006), em que a marca de dativo -ja/-wa na língua é derivada do afixo locativo (alativo) *CL-O em proto-ândico. 
Dessa forma, não nos parece que se possa desvencilhar totalmente (no sentido de delimitar precisamente) os sentidos típicos associados ao dativo (como recipiente/alvo em verbos de transferência) de sentidos locativos, parecendo que tanto um como o outro têm em comum uma zona de convergência semântica de natureza espacial, sendo mais geral a ambos (em contraste, por exemplo, com sentidos mais especializados que cada um pode vir a adquirir dentro do sistema de determinada língua).

De fato, o que se observa nas línguas leste-caucasianas é que muitas das construções marcadas com o dativo que observamos até o momento são também abarcadas por casos locativos, dentre elas, as já exemplificadas construções experienciais, contruções possessivas (com o verbo ser), posse externa e não intencionais. Abaixo, alguns exemplos de construção possessiva em (228) da língua tsez, de contrastes de volicionalidade/intencionalidade em (229) do lezguiano, e de posse externa com um caso locativo na língua andi (230):
zhek'qo
Somoy
yoL
homem.ESS macaco.ABS ser.PRES

O homem tem um macaco. (COMRIE \& POLINSKY, 1998, p.108)

(229) a. zamira-di get'e xa-na

Zamira-ERG vaso quebrar-PAST

Zamira quebrou o vaso. (HASPELMATH, 1993, p.291-3)

$\begin{array}{ccl}\text { b. zamira.di-w-aj } & \text { get'e } & \text { xa-na } \\ \text { zamira-AD-EL } & \text { vaso } & \text { quebrar-PAST }\end{array}$

Zamira quebrou o vaso acidentalmente/involuntariamente.

(HASPELMATH, 1993, p.291-3)

$\begin{array}{lllll}\text { (230) } & \text { di-ch’u } & \text { honow } & \text { hek'a } & \text { rok’o-lla } \\ & \text { 1SG-CONT } & \text { esse } & \text { pessoa } & \text { coração-SUPER }\end{array}$

Eu me lembro dessa pessoa (lit. 'essa pessoa está no meu coração'.

(GANENKOV, 2006, p.181) 
É possível argumentar a partir dessa discussão que dativos e locativos têm possivelmente uma aproximação conceitual que é refletida em algumas línguas através dos tipos de construções que abarcam e por terem, muitas vezes, correspondências em termos de origem.

É importante também recordar da discussão feita na seção sobre posse, em que foi exposta a análise de Langacker de possessivos e locativos e sua conexão conceitual, dessa análise fica em evidência a relação entre construções com objetos indiretos e locativos (observe os exemplos dados na seção como um todo e a análise do autor do japonês).

A essa conexão entre locativos e dativos e sua relação com a conceitualização de eventos experienciais, voltaremos a discutir no capítulo 7.

Na seção seguinte, dada essa aproximação entre locativos e dativos, acreditamos ser importante discutir o papel que locativos e adposições (preposições e posposições) teriam na gramática das línguas e na conceitualização de eventos de acordo com a GC de Langacker.

\subsection{A esfera ativa e a esfera circunstancial: o papel de locativos e adposições}

Na GC, duas distinções arquétipas são fundamentais em nossa experiência: a noção de participantes em contraste com a de cenário (setting). Essa distinção reflete o fato experiencial de que tanto nós quanto as entidades com as quais interagimos serem pequenas e compactas relativamente à extensionalidade muito maior do entorno espacial.

Assim, as entidades físicas que nos cercam são vistas a partir de um espectro que vai de participantes canônicos a cenários espaciais mais globais, cada um representando um extremo.

Tipicamente, participantes englobam pessoas, animais e objetos físicos; desses, o mais canônico, por ter uma série de características salientes, é a concepção de pessoa, pois em relação ao cenário que nos abrange, pessoas são pequenas, delimitadas, móveis, sencientes, energéticas e vivas (LANGACKER, 2010). Em contraste, típicos cenários incluem salas, prédios, cidades e nações, além de cenários delimitados como 
continentes, vales ou um campo. ${ }^{166}$ Desses extremos, há entidades que podem ser consideradas tanto como canonicamente participantes quanto cenários como animais e objetos facilmente manipuláveis.

Observe, no entanto, que apesar de os arquétipos conceituais serem básicos em nossa experiência, i.e., na forma como apreendemos o mundo ao redor, não são intrínsecos no mundo. Assim, certas entidades podem ser construídas mais como participantes ou mais como cenários a depender do construal, i.e., uma entidade pode ser categorizada de formas diferentes conforme a situação e como o falante escolhe construir essa situação, com base nos recursos da sua língua disponíveis.

Nessa concepção arquetípica, participantes são concebidos como interagindo uns com outros, e apenas ocupando cenários e locais, de modo que é possível interagir de diversas formas com, por exemplo, um objeto, afetando aquele objeto de diferentes formas em termos de dinâmica de forças (ao manuseá-lo, quebrá-lo, mudá-lo de lugar, etc.). O mesmo, no entanto, não pode ser dito de nossa interação com locais, já que ocupamos esses locais e não normalmente interagimos forçosamente com eles, afetando-os, da mesma forma que com objetos mais facilmente manipuláveis.

Cada extremo desse espectro representa uma esfera da experiência humana: a esfera ativa que abrange aspectos fundamentais como da ação, da mudança e da força e onde as entidades móveis, como um agente humano volitivo, age no mundo; e a esfera circunstancial que abrange cenários, locais e situações estáticas e onde objetos com propriedades estáveis são organizados de determinada forma. Essas esferas são complementares e interdependentes na medida em que enquanto circunstâncias possibilitam o potencial para atividade e fornecem o cenário onde se desenvolve; a atividade altera as circunstâncias e o potencial para atividades subsequentes (LANGACKER, 2010).

Como argumenta o autor, essas esferas, apesar de sua complementaridade, possuem um status desigual do ponto de vista humano, não sendo apreendidas de forma neutra, de forma que a esfera ativa é central, e a circunstancial, mais periférica. Essa assimetria, ou não neutralidade, decorre da saliência de pessoas como atores e centros de seu próprio universo, ocasionando uma perspectiva egocêntrica a partir de sua posição em um extremo.

\footnotetext{
${ }^{166}$ Nessa concepção, um local é qualquer porção do cenário delimitada em razão de algum propósito, tal como um lugar onde uma pessoa pode ser localizada (LANGACKER, 2010).
} 
O reflexo dessa assimetria na gramática das línguas é variado e já foi notado na literatura de uma forma ou de outra. Na organização da sentença, por exemplo, já se notaram as diferenças entre nominais em função de sujeito e objeto (conceitualmente, codificando mais participantes) e aqueles com função adverbial (codificando preferencialmente cenários e locais), sendo os últimos usualmente opcionais, introduzidos de forma perifrástica por adposições ou casos com conteúdo semântico mais evidente (como locativos); e os primeiros, normalmente obrigatórios e marcados por casos mais 'gramaticais'.

Observe que, como Langacker (2010) coloca, de uma perspectiva egocêntrica de humanos agentivos, se a esfera ativa é central e a esfera circunstancial é periférica, um dos interesses primários seria codificar ações e eventos e apenas secundariamente circunstâncias estáticas.

Como vimos anteriormente, em uma interação canônica entre agente e paciente, o agente é prototipicamente um participante que age de forma intencional, funciona como fonte de energia e não sofre mudança de estado em decorrência do evento; em contraste, o paciente é seu oposto em todos os aspectos, é inanimado e não volitivo, absorve energia e sofre mudança de estado em decorrência disso. Por essa perspectiva, os arquétipos de agente e paciente representam um contraste máximo observado dentro da própria esfera ativa, e não entre centro e periferia.

Consequentemente, a assimetria que se verifica na oposição entre os arquétipos de humano agentivo e o cenário mais global não se traduz necessariamente como os elementos mais proeminentes na organização da sentença (pelo menos em termos de codificação de uma interação canônica).

Naturalmente, como já foi observado ao longo desta tese, apesar da pervasividade do modelo de evento canônico nas línguas e de sua codificação (normalmente através da construção transitiva), atestando para sua importância de uma perspectiva egocêntrica, há desvios desse padrão na medida em que a língua e os recursos nela disponíveis devem abrigar e descrever uma imensa variedade de situações, sendo comum que haja extensões dessa codificação a outros eventos (como eventos emocionais).

Como discutido em Langacker (2010), isso não quer dizer que não existam outras construções básicas nas línguas para codificar determinados eventos, tais como aqueles que descrevem situações estáveis na esfera circunstancial. De fato, um padrão comum para descrever esse tipo de evento básico é usar um predicado como o verbo 
'estar/ser', cujo complemento pode especificar uma propriedade do sujeito ('A caneta é leve’) ou um local espacial ('A caneta está na mesa').

Interessantemente, o autor argumenta que mesmo nesses casos típicos de expressões da esfera circunstancial, haveria uma influência da esfera ativa na medida em que concebemos a esfera circunstancial como um palco para a ação humana, i.e., onde se desenvolvem atividades e ações.

Um caso dado pelo autor é a base interativa de expressões circunstanciais tais como as citadas acima, se um objeto é dito como leve é porque em algum momento houve uma interação com aquele objeto, como ao levantá-lo ou manuseá-lo. A mesma base interativa pode ser observada ao se descrever que 'a caneta está na mesa', havendo ainda que tênue, uma concepção de movimento ou atividade envolvendo o objeto, por exemplo, como ele foi parar em cima da mesa, como achá-lo para usá-lo, etc. ${ }^{167}$

Também se observa a influência da esfera ativa nas entidades escolhidas como trajetor e marco em sentenças tais como 'Maria está na casa', em que o primeiro é um participante e o segundo é um cenário (ou local). Note que sentenças como essas são mais canônicas do que sentenças como o 'O Canadá está na América do Norte', em que ambas as entidades são cenários. E isso se daria justamente em razão de as entidades gravitarem em torno da esfera ativa, pois enquanto o trajetor escolhido se aproxima de um extremo do espectro, o marco escolhido estaria no meio (um local delimitado), não no extremo oposto (o do cenário abrangente).

Como argumenta o autor, em sentenças que descrevem situações estáticas, de fato, o trajetor canonicamente escolhido é uma pessoa ou algum objeto que se move ('a blusa está naquele armário'). Ainda assim, nota-se que o papel desse participante não é o mesmo de uma interação prototípica na esfera ativa, já que, ao contrário da esfera ativa, noções como de ação, mudança e força são tênues ou quase nulas nessas situações mais estáticas.

\footnotetext{
167 Como discutido em Langacker (1995, p.52), a maior parte das propriedades adjetivais pode ser caracterizada com relação a alguma atividade ou processo interativo envolvendo a entidade à qual é atribuída a propriedade, variando em quanto essa atividade ou processo é saliente ou menos saliente. Por exemplo, em um adjetivo como 'azul', o processo interativo de 'ver' é menos saliente (e mais esquemático) do que com um adjetivo como 'visível'. Em expressões como 'o sorvete está duro' ou 'a superfície é dura', o adjetivo 'duro' indica resistência a alguma coisa tentando penetrar ou deformar sua superfície, evocando um processo de dinâmica de forças que tem o potencial de resultar nessa deformação, o que envolve nesse processo uma fonte de energia, sendo um agente humano o default. Esse processo, no entanto, é esquemático, i.e., essa propriedade é caracterizada em termos de um processo interativo esquemático que não é em si perfilado.
} 
Nesses casos, o papel de uma pessoa que meramente ocupa um local representa um caso de atenuação relativamente ao arquétipo de um humano agentivo e volitivo em uma interação canônica, ou mesmo em relação a outros tipos de eventos envolvendo movimentação no espaço (como em 'Ela andou ao longo do rio'), em que o trajetor ocupa uma série de posições através do tempo, diferentemente de situações estáticas, em que o trajetor ocupa a mesma posição ao longo do tempo, consistindo, portanto, em um caso degenerado de movimento (LANGACKER, 2010).

Essa atenuação também acontece com um objeto que meramente ocupa um local, relativamente ao papel arquetípico de paciente. Ao contrário deste último, que é afetado no sentido de sofrer uma mudança de estado, em 'Ela colocou o livro na mesa', por exemplo, o marco apenas é afetado no sentido de sofrer uma mudança de local.

Observe que tanto em relação à escolha do trajetor quanto do marco, há uma inflência de aspectos interativos da esfera ativa. Expressões estáticas como 'Ela está na garagem' podem indicar uma série dessas interações, tais como a de que a pessoa poderá ser encontrada no lugar indicado ou que o fato de a pessoa se encontrar em tal lugar possibilita que ela conduza determinadas ações, podendo também indicar o porquê de a pessoa ter se movido para aquele lugar. $\mathrm{O}$ mesmo acontece em expressões como 'A caneta está na mesa', em que o fato de o objeto ocupar determinado lugar, torna possível que esse objeto seja encontrado e que alguém talvez possa usá-lo, ou mesmo pode indicar que alguém o colocou lá por alguma razão (LANGACKER, 2010).

Outro dado apontado pelo autor é que usualmente o marco de preposições espaciais tende a estar numa escala intermediária de distância (em relação ao espectro entre a esfera ativa e circunstancial). É mais comum que entidades que tenham uma região delimitada ou sejam fechadas, ou mesmo regiões geográficas de extensão limitada, sirvam como marcos espaciais para localizar outras entidades, por exemplo, 'Jill está na sala/em casa/no jardim/em Chicago' (em contraste com sentenças pouco informativas como 'Suas chaves estão na América do Norte').

Outros tipos de entidades como objetos materiais, devido ao tamanho e sua imobilidade relativa, também são frequentemente construídos como locais em vez de participantes, tais como: uma escrivaninha, um banco, uma banheira, etc. O que não impede que entidades normalmente construídas como participantes (menores e mais facilmente manipuláveis de um ponto de vista interativo) sirvam como marcos espaciais como em 'Está no meu bolso/debaixo da revista/atrás do vaso', etc. 
E essa característica intermediária das entidades escolhidas como marcos reflete justamente seu aspecto referencial. Recordando a caracterização de Langacker (explicitada na seção sobre posse) sobre ponto de referência, preposições espaciais indicam uma região no espaço (o domínio de busca), caracterizada em relação ao marco, e dentro da qual o trajetor pode ser encontrado. Dessa forma, o conceitualizador, acessando o ponto de referência, consegue localizar a entidade dentro do domínio de busca.

Assim, como pontos de referência, em casos canônicos, preposições espaciais usualmente designam uma relação entre um participante e um local que se encontra em posição intermediária na escala de distância, indicando que preposições espaciais têm uma posição que abrange tanto a esfera ativa quanto circunstancial. Nesse ponto, interessantemente, as relações espaciais que designam também seriam intermediárias considerando-se a natureza estática da esfera circunstancial e a natureza interativa da esfera ativa. Embora sejam relações estáticas, são usualmente construídas em relação à interação e movimento (LANGACKER, 2010).

Como foi visto até aqui, um evento como ' $O$ gato está debaixo da cama', segundo o autor, seria estável apenas de forma local, sendo concebido normalmente como resultado de o gato ter se movido para lá em razão de algum propósito ou para se perguntar como tirá-lo de lá ou encontrá-lo. 


\section{A CONCEITUALIZAÇÃO DE EVENTOS EXPERIENCIAIS}

\subsection{Introdução}

Neste capítulo final discutiremos a caracterização conceitual de eventos experienciais com base no que temos visto e argumentado até aqui.

Começaremos por continuar a expor a análise de Kövecses (2005) (cf. 2.2.7), em que falaremos sobre a metáfora mais geral mostrada pelo autor 'EMOÇÕES SÃO FORÇAS' que haveria no domínio experiencial. Dessa metáfora, será salientada e discutida a concepção de evento experiencial metaforicamente concebido como causado externamente, explorando as diferentes marcações e construções nas línguas que instanciariam essa concepção.

Importantemente, discutiremos dados que apontariam para uma origem do experienciador dativo como recipiente/alvo de eventos experienciais metaforicamente concebidos como causados externamente.

Na seção seguinte, damos continuidade à discussão, estabelecendo relações entre a concepção de eventos experienciais como causados externamente e a bidirecionalidade de eventos experienciais. Resumidamente, argumentaremos que essa concepção corresponde a uma porção perfilada de uma concepção mais abstrata de eventos experienciais como bidirecionais, e que a mudança de proeminência observada em construções dativas em georgiano (e outras línguas) teria relação justamente com uma mudança de perfil conceitual, i.e., em qual porção do evento experiencial bidirecional estaria sendo perfilado.

Na seção 7.4, iremos trazer a relação conceitual entre locais, experienciadores e a noção de bidirecionalidade. Veremos como em marcações de experienciadores que se diriam 'estáticas', haveria a influência de aspectos da esfera ativa de um ponto de vista egocêntrico, como interação e movimento.

Também explicitaremos a natureza da conceitualização de eventos experienciais bidirecionais por meio do estabelecimento de como noções arquetípicas de nossa experiência no mundo, como o 'externo' e o 'interno', estariam presentes nessa concepção abstrata e mais geral. 
Por fim, concluímos com a relação dessa conceitualização com a mudança observada em georgiano. E salientamos por último, com base no que vimos ao longo da tese, as construções dativas como a formar uma família de construções.

\subsection{Eventos experienciais concebidos como causados externamente: introdução e conexão com construções experienciais dativas (e locativas).}

Relembrando nossa discussão na seção 2.2.7 sobre metáfora conceitual, mencionamos que a análise de Kövecses (2005), observando certas similaridades nas metáforas utilizadas para conceitualizar emoções como amor e raiva, argumenta que haveria uma metáfora mais geral que permearia a conceitualização do domínio das emoções.

Para o autor, metáforas mais específicas tais como EMOÇÃO É UM OPONENTE (e.g., no português: 'Ele estava lutando contra suas emoções', 'Ela foi tomada por suas emoções’); EMOÇÃO É UMA FORÇA NATURAL (e.g., no inglês: 'He was overwhelmed by his emotions', 'She swept me off my feet'); EMOÇÃO É UMA FORÇA FÍSICA (no inglês: 'When I found out, it hit me hard', 'That was a terrible blow', 'I am attracted to her'), são instâncias de uma conceitualização mais geral de EMOÇÕES SÃO FORÇAS (em uma relação abstrata de dinâmica de forças (cf. seção 2.2.6 em que mencionamos o conceito de dinâmica de forças de Talmy (1988)).

Em um cenário mais básico e esqueletal de emoção, como delineado por Kövecses (2005), há uma causa que induz alguém a ter uma emoção, e a emoção, por sua vez, causa esse alguém a produzir alguma resposta. Há então duas partes desse cenário, a primeira em que a causa leva a emoção, e a segunda em que a emoção leva a alguma resposta. Tanto a 'causa' na primeira quanto a 'emoção' na segunda são entendidas como forças.

As metáforas que tenderiam a focar na primeira parte seriam aquelas relacionadas, por exemplo, à FORÇA FÍSICA. Já as metáforas que tenderiam a focar na segunda parte seriam aquelas relacionadas a OPONENTE, FORÇA NATURAL e SUPERIOR.

Interessantemente, a metáfora EMOÇÕES SÃO FORÇAS emerge de duas metáforas mais gerais, sendo uma delas decorrente de uma concepção metafórica de 
eventos mais geral: a de que CAUSAS SÃO FORÇAS. Observe que na primeira metáfora, EMOÇÃO remete também metonimicamente às suas causas, já que há a concepção acima de que emoções teriam causas (discutiremos mais sobre esse ponto nas seções seguintes).

Lakoff (1992), analisando a base metafórica da estrutura de eventos a partir do inglês, observa que há diversos mapeamentos metafóricos de noções como estados, mudanças, processos, ações, propósitos e meios em termos de espaço, movimento e força. Alguns dos mapeamentos metafóricos observados são: estados são locais (regiões delimitadas no espaço); mudanças são movimentos (dentro ou fora de regiões delimitadas); causas são forças; propósitos são destinos; dificuldades são impedimentos ao movimento; dentre outros.

A que mais nos interessa no momento, portanto, é a metáfora CAUSAS SÃO FORÇAS, em que causas de eventos são metaforicamente vistas como forças que trazem mudanças de um estado a outro, por essa perspectiva, causatividade seria entendida através do conceito experiencial de força.

Vejamos, assim, alguns exemplos de como a dinâmica de forças se aplicaria ao domínio abstrato das emoções segundo Kövecses (2005).

Na metáfora, EMOÇÃO É UM OPONENTE, haveria uma situação de dinâmica de forças em que há dois oponentes em uma luta, um deles é mais passivo (aquele que é tomado pela emoção) e tenta resistir à força, e o outro é aquele que é ativo e tenta fazer com que o oponente inativo ceda à sua força. $\mathrm{O}$ oponente mais passivo no domínio fonte é mapeado como o experienciador no domínio alvo, e o segundo oponente no domínio fonte é mapeado como a própria emoção no domínio alvo. Enquanto o experienciador tenta manter controle sobre a emoção, a emoção tenta causar a perda de controle por parte do experienciador. Para Kövecses (2005), a ação resultante dessa dinâmica de forças (no domínio da emoção, a resposta emocional ou comportamental produzida), é que ou se perde o controle para a força (a emoção) ou se mantém o controle, resistindo à força (a emoção).

Já na metáfora, EMOÇÃO É UMA FORÇA NATURAL, subjaz um evento de dinâmica de forças, em que uma força natural (como vento, chuva, onda) afeta um objeto físico que não pode fazer nada, além de sofrer seus efeitos destrutivos. Ao conceitualizar esse evento como emoção, há metaforicamente o entendimento de que somos passivos em relação a emoções como forças naturais poderosas que nos afetam. 
Dessa forma, o experienciador responde à emoção como força de forma mais passiva, de forma a sofrer seus efeitos.

Em relação à metáfora EMOÇÃO É UMA FORÇA FÍSICA, no evento de dinâmica de forças, há um objeto físico que tem uma tendência ao repouso de modo a permanecer no estado de antes, e outra entidade que exerce uma força física para produzir algum efeito no objeto. O mapeamento desse domínio fonte ao domínio alvo da emoção ocorre de forma que o experienciador tenta se manter da mesma forma (sem ser afetado pela emoção), enquanto a causa da emoção tem a tendência, como força, de causar o experienciador a tornar-se afetado pela emoção. A ação resultante dessa dinâmica de forças é a afetação do experienciador, i.e., ele torna-se emocional. ${ }^{168}$

Para Kövecses (2005), a maior parte das metáforas no domínio da emoção (mas não todas) podem ser caracterizadas como uma interação de forças, sendo que grande parte das metáforas de emoção são instanciações específicas da metáfora mais geral EMOÇÕES SÃO FORÇAS, cada qual tendo um papel diferente na conceitualização do domínio da emoção.

A explicação de Kövecses (2005), de fato, abarca um aspecto importante da conceitualização de eventos experienciais, que é justamente aquele que concebe o evento experiencial como causado por algo externo ao experienciador e do qual não se tem controle.

Normalmente esses eventos são codificados por meio de construções em que o experienciador é o 'objeto', embora não seja regra (observe, por exemplo, a construção citada acima 'Ela lutou contra os seus sentimentos', em que o experienciador é sujeito e a emoção é metaforicamente conceitualizada como uma força).

Durante diversos momentos da tese, vimos construções que codificam, ainda que de formas diferentes a depender da língua, esse aspecto da conceitualização de eventos experienciais. Por exemplo, no capítulo 3, vimos construções ObjExp estudadas sob diferentes perspectivas (e, por vezes, com diferentes subclassificações), mas que notavam a importância de noções como causalidade.

A análise de Croft (1993) (cf. nossa discussão nas seções 3.2 e 5.8), por exemplo, atribuía a variação na marcação de argumentos de verbos experienciais aos verbos estativos, argumentando que verbos experienciais causativos (ObjExp) e verbos

\footnotetext{
168 É interessante observar certas expressões no português que constroem eventos experienciais como forças físicas que agridem o experienciador de forma não controlável, tais como 'me bateu um cansaço/sono/tristeza'.
} 
incoativos não apresentariam essa variação translinguisticamente por terem uma direcionalidade causal única, envolvendo mudança de estado ou transmissão de força.

Também foram citados ao longo da tese exemplos de eventos experienciais vindos diacronicamente de eventos mais concretos envolvendo transmissão de força ou movimento, tais como aqueles mencionados por Haspelmath (2001) do inglês, como o verbo worry 'preocupar' que significava 'estrangular, segurar pela garganta', preoccupy 'segurar de antemão', stun 'privar de consciência com um golpe', fascinate 'jogar um feitiço sobre'. Observe que em todos esses exemplos o experienciador não tem controle sobre o evento, sofrendo os efeitos de uma força (a emoção) que recai sobre ele ou o domina.

Em choctaw, também foram notadas (seção 5.3.1) expressões derivadas de eventos causais físicos tais como nokshila 'ter sede' em que shila significa 'secar, estar seco'; nokpowalli 'sentir-se enjoado' em que powalli significa 'causar ondas'; havendo, em georgiano, exemplo similar ao último: guli m-e-reva 'eu (dat.) me sinto enjoado, sinto ânsia' em que o verbo rev-s significa 'misturar, bagunçar'.

Assim como o georgiano (cf. exemplos na seção 5.8), que usualmente marca construções experienciais causais através da construção transitiva com o experienciador como objeto (ou em alguns casos através da construção marcada causativa em georgiano), muitas línguas também assim o fazem, i.e., ou por meio de construções transitivas ou através de uma marcação causativa mais marcada.

De fato, é interessante observar a pervasividade de construções marcando eventos experienciais causados externamente (aqui também englobando construções de transmissão de força ou mesmo movimento) nas línguas, parecendo que a maior parte, senão todas, faz uso de algum meio, construção ou recurso linguístico para marcar uma relação em que a experiência é causada por algo externo ao experienciador.

Ainda que uma investigação tipológica mais completa deva ser feita, essa aparente pervasividade de construções (que de alguma forma instanciam mapeamentos metafóricos no domínio da emoção relacionados à interação de forças) atesta, como argumenta Kövecses (2005), a existência de uma metáfora mais geral no modo como conceitualizamos o domínio abstrato da emoção, não significando, como já foi enfatizado na seção 2.2.7, em alguma forma de limitação ou de exclusividade, mas apenas constituindo uma maneira experiencialmente saliente o suficiente para ser utilizada. 
É interessante notar que a codificação por meio da construção transitiva de eventos experienciais causais, como muitas vezes é o caso, indica como a língua faz uso de recursos disponíveis para marcar uma miríade de expressões que nem sempre são as ocorrências mais prototípicas daquela construção.

Conforme é possível relembrar da discussão na seção 2.2.6, uma construção pode ser menos ou mais transitiva, transitividade sendo uma noção conceitual e escalar. Assim, quanto maior o grau de aproximação de uma interação canônica entre agente e paciente, mais transitiva aquela construção, a princípio, será.

Langacker chama de 'modelo de evento canônico' a forma mais canônica de ocorrência de um evento energético em que um agente interage com um paciente através de contato físico e transmissão de energia, provocando uma mudança de estado, sendo essa situação assimétrica na medida em que há uma direcionalidade do fluxo de energia e em razão de o agente induzir esse contato ao se mover em direção ao paciente.

Essa visão de transitividade conceitual se alinha com a visão de transitividade de Hopper \& Thompson (1980), em que o número de participantes em um evento seria apenas um dos parâmetros considerados para se medir a transitividade da sentença, havendo outros parâmetros como aspecto (télico ou atélico), pontualidade, volicionalidade, afirmação (se afirmativa ou negativa), modo (realis ou irrealis), agentividade e afetação e individuação do objeto.

Observe que, dadas algumas características de uma construção experiencial causal, a codificação através da construção transitiva torna-se uma opção saliente o suficiente para ser frequentemente adotada. Dentre essas características, é, por exemplo, a existência de dois participantes em uma relação, ainda que metafórica, energética, em que o agente (a causa ou outra entidade volicional como estímulo) afeta o experienciador, trazendo uma potencial mudança de estado (emocional, físico ou perceptual). Como menciona Langacker (1999), uma entidade senciente, ao criar uma representação de entidades sem existência física real, faz contato mental com essas entidades, podendo construir essa entidade como externa a ele, concebendo-a como se movendo mentalmente em sua direção.

Por outro lado, um evento experiencial causal também tem características que o fazem se afastar do protótipo (o modelo de evento canônico), resultando muitas vezes em desvios desse protótipo. Por exemplo, a afetação sofrida pelo experienciador difere daquela que um objeto físico, em termos de dinâmica de forças, pode sofrer. 
Observe que o grau de afetação do objeto é frequentemente marcado nas línguas através de marcações diferenciais, no português, uma sentença como 'Ele comeu a maçã' se diferencia de 'Ele comeu da maçã' justamente pelo grau de afetação do objeto, em que a primeira implica que a maçã foi toda comida, já na segunda, apenas uma parte.

A afetação do experienciador em um evento experiencial, tal como argumenta Maldonado (2002) (cf. seção 6.3), decorre mais de sua atividade, isto é, do fato de que o experienciador é senciente, pressupondo contato mental e tendo o potencial de reação posterior (cf. a discussão na seção 6.3 sobre verbos de interação e outros verbos marcados como objeto indireto).

Como mencionamos na seção, Maldonado (2002) analisa a diferença de marcação de verbos experienciais que apresentam variação na marcação do objeto (ObjExp), ora no acusativo ora no dativo. Para o autor, haveria uma diferença conceitual relativa à diferente afetação do experienciador em cada caso. Seja como for, essa diferença pode naturalmente ser neutralizada (ou construída de forma menos saliente), e a afetação do experienciador como mais ativo pode vir a ser obscurecida por sua marcação com o acusativo, como ocorre em muitas línguas. No entanto, uma marcação dativa do experienciador pode significar sua relativa diferenciação conceitual em relação à afetação de um objeto físico em um evento mais canônico de interação entre agente e paciente. ${ }^{169}$

A construção transitiva, no entanto, não é o único modo de codificar eventos experienciais causais (i.e., conceitualizados como externamente causados ou despertados no experienciador). $\mathrm{E}$ isso é de se esperar visto que, como mencionam Lakoff \& Johnson (1980), costumamos conceitualizar o que é menos delineado, como conceitos abstratos, em termos do que é mais bem delineado, como objetos concretos, com os quais podemos interagir e manipular de diferentes formas. Essas diferentes interações podem servir como domínio fonte para a conceitualização de experiências tão básicas quanto, como sentir sensações e sentimentos, mas que pertencem a um domínio mais abstrato de nossa experiência no mundo.

\footnotetext{
169 Para Langacker (1991), por exemplo, quando o experienciador é codificado como objeto direto (como em sentenças do inglês ObjExp 'Her behaviour shocked me'), seria destacada a natureza passiva da participação do objeto, em que o evento é construído como sendo causado por uma força externa que supera ou suplanta o papel iniciativo do experienciador. Acreditamos, no entanto, que a natureza iniciativa em eventos desse tipo, também discutidos acima, permanece, porém de forma menos saliente no evento.
} 
Construções de transferência são um exemplo frequente de codificação de eventos abstratos como emoções. Por exemplo, no inglês 'it gives me hope', 'it gives me the creeps'; em português 'isso me dá raiva/medo/vontade'.

Observe que em um evento de transferência (também chamado de movimento causado) há também interação de forças, de modo a causar um objeto a se mover de uma entidade para outra, sendo um verbo como 'dar', com três participantes, agente, paciente (aquele que se move) e recipiente, prototípico desse tipo de evento (cf. seção 6.3). Nesse evento, um agente exerce alguma força para impulsionar o paciente (aquele que se move) física ou abstratamente de sua esfera de controle (seu domínio) para a esfera de controle do recipiente, sendo, portanto um evento energético em que há transmissão de energia do agente ao paciente e que resulta no movimento desse paciente. ${ }^{170}$

Como aponta Langacker (1991; 1999), o papel do recipiente é complexo, ele não é apenas um possuidor final do evento de transmissão, mas também tem características experienciais e volitivas na medida em que percebe a mudança de posse e faz contato mental com o objeto, exercendo controle sobre ele. Dessa forma, o recipiente/experienciador é ativo e iniciativo, diferentemente de um paciente que é totalmente passivo.

Para o autor, tanto o papel de recipiente (subsequentemente um possuidor em um contexto de transferência) quanto experienciador são básicos e salientes o suficiente em nossa experiência para serem considerados candidatos prototípicos da categoria de objeto indireto (cf. a discussão na seção 6.3), já que estão intimamente conectados e são frequentemente difíceis de se distinguir.

Em verbos de comunicação (como 'contar'), por exemplo, em que há uma transferência abstrata, o objeto indireto é um experienciador na medida em que é senciente, percebe o que é transmitido e compreende a mensagem, ao mesmo tempo que é também recipiente, pois recebe a mensagem, sendo um subsequente possuidor dessa informação.

Em eventos experienciais de transferência como aqueles exemplificados acima, ainda que por meio de construals diferentes, ainda é possível observar a metáfora mais

\footnotetext{
170 Interessantemente, no português, a versão mais marcada de um evento de transferência com o verbo 'receber' (cf. Langacker, 1991), que perfila apenas a parte em que o recipiente recebe o objeto, também ocorre metaforicamente no domínio da emoção como no exemplo 'eu recebi um baque quando soube', em que 'baque' (o evento emocional) é concebido como uma força externa que é 'recebida' pelo experienciador.
} 
geral delineada por Kövecses acima, EMOÇÕES SÃO FORÇAS. Pois, metaforicamente, há um agente (a causa da emoção) que exerce uma força de forma a impulsionar a emoção para o domínio do experienciador. Observe que nesses casos, é salientada a afetação mais ativa do experienciador, isto é, o fato de o experienciador fazer contato mental com a entidade recebida (a emoção). Em todo o caso, o evento emocional é tido como sendo pouco controlável por parte do experienciador, ou seja, o evento emocional é concebido como uma força externa imposta ao experienciador e do qual ele não tem controle.

Observe que dada a forma como o experienciador dativo é concebido em casos como esses torna-se difícil diferenciar o objeto indireto como recipiente ou alvo da emoção causada, já que ao mesmo tempo em que o experienciador recebe a emoção, sendo seu recipiente propriamente, também é concebido como alvo da força externa.

Essa não diferenciação é ainda mais evidente conforme observamos outras construções que vão cada vez mais se distanciando de um evento típico de transferência com três participantes e no qual o recipiente/experienciador seria o último participante na cadeia de ação (para Maldonado (2002), construções essas mais 'periféricas' relativamente ao esquema de transferência, cf. seção 6.3).

As construções experienciais abaixo são compostas por verbos que, em seu sentido original ou literal, denotam algum tipo de movimento em direção ao alvo dativo. Em (231) e (232), temos exemplos de línguas indo-arianas, hindi-urdu e punjábi respectivamente, e em (233) e (234), exemplos de línguas dravídicas como kannada e tâmil respectivamente:

(231) skuul-ka maidan dekhkər ləRke-ko dost yad ae. escola-da campo ver garoto-DAT amigos memória vir O garoto se lembrou dos amigos quando viu o terreno da escola. (Lit.: Uma memória dos amigos veio ao garoto quando viu o terreno da escola.). (KACHRU et al., 1976)
saa nüü
gussaa
aaiaa
1PL.OBL DAT
raiva.MASC
vir.PAST.MASC

Nós ficamos com raiva. (Lit.: a raiva veio até nós). (BHATIA, 1993) 


$$
\begin{array}{lll}
\text { nanage } & \text { taleno’vu } & \text { bantu } \\
\text { 1SG.DAT } & \text { dor.de.cabeça } & \text { vir }
\end{array}
$$

Eu fiquei com dor de cabeça. (Lit.: veio a mim a dor de cabeça) (SRIDHAR, 1979)

(234) avan-ukku kāyccal viț-ṭ-atu.

3SG.DAT febre deixar-PAST-3SG.NEUT

Ele está livre de febre. (Lit.: A febre o deixou.) (HOCK \& BASHIR, 2016)

Nos três primeiros exemplos, o sentido literal da construção é dado por verbos chamados de 'leves', tais como o verbo intransitivo 'vir' nesses exemplos, em conjunto com um substantivo denotando a emoção que seria concebida, assim, como 'vindo' até o experienciador no caso dativo.

Já no último exemplo, a condição física, a febre, é concebida como deixando o experienciador no caso dativo em vez de ir ao encontro dele, significando que ele se curou da febre.

Novamente, essas construções, em que o evento experiencial é construído como algo externo que vem até o experienciador e o afeta, denotam em decorrência o pouco controle por parte do experienciador e sua não volicionalidade em relação àquele evento. Tanto que da mesma forma que a emoção ou sensação vem para o experienciador de forma não controlável, ela também pode deixá-lo (como em (234)).

Além dos casos citados com dativos de (231) a (234), exemplos parecidos podem ser encontrados com locativos em línguas leste-caucasianas, parecendo também indicar uma origem em que a emoção é conceitualizada como sendo provocada externamente ao experienciador.

O exemplo a seguir ilustra um evento experiencial, significando 'esquecer' em lezguiano, que se assemelha ao exemplo visto em (234) acima, só que com um caso locativo, em que um verbo de movimento, 'ir', é usado, tendo o significado literal de que as palavras saíram do domínio do experienciador sem seu controle: 
i mani.di-n gaf-ar zi rik'e-l-aj fe-na

essa música-GEN palavra-PL meu coração-SUPER-EL ir-PAST

Eu esqueci as palavras dessa música. (lit. 'as palavras dessa música foram embora do meu coração.’) (GANENKOV, 2006, p.182)

O caso acima é interessante, pois, como discutimos na seção 6.4, atesta novamente para uma relação próxima entre locativos e dativos em termos de semelhança entre os tipos de eventos que abarcam.

Ademais, vimos, ao longo da tese, diversos exemplos do georgiano e outras línguas que deixam transparecer uma origem em que o evento emocional ou físico é concebido como vindo em direção ou ocorrendo ao dativo. Reveja, por exemplo, a discussão na seção 5.3.2 sobre o verbo hgonia 'achar, parecer' em georgiano e equivalentes em outras línguas; a discussão sobre verbos modais (seção 5.3.3), observando os exemplos do russo como mne mozhno (lit. 'é possível para mim'), do irlandês (exemplo (88)) e também discussão nas páginas 171-173; cf. também discussão sobre a relação da vogal pré-radical - $e$ - em georgiano (que marca objetos indiretos em verbos intransitivos) com nuances experienciais e de não volicionalidade (p.211-216).

Observe, aliás, que em relação à vogal pré-radical -e-, é, inclusive, difícil em algumas circunstâncias e sem contexto discernir se a interpretação do nominal dativo, marcado pela vogal pré-radical - $e$ - em verbos intransitivos, deve ser a de um alvo puramente ou se a interpretação mais adequada é, de fato, a de um experienciador. Por exemplo, nos exemplos (141) e (142) com o verbo $e$-chven-eb-a, se não fosse o contexto dado em (b) (do sonho), - ou em outros casos, a pluralidade em - $t$ no verbo marcando o dativo plural -, seria difícil divisar a leitura apropriada da sentença.

Mesmo em relação a línguas em que não é possível dizer que há construções dativas propriamente (i.e., com o experienciador como sujeito), como é o caso do português, é interessante notar que construções com sentidos similares também ocorrem, i.e., construções em que o evento experiencial é concebido como sendo algo causado externamente e que afeta o experienciador sem seu controle. 
Observe que as construções a seguir denotam um evento de pouco controle por parte do experienciador, a emoção ou sensação física sendo concebida como uma força que acomete o experienciador: ${ }^{171}$

(236) De repente, me deu um sono/uma tristeza.

(237) De repente, me veio um sono/uma tristeza.

(238) De repente, me bateu um sono/uma tristeza.

Construções como as de (231) a (235) e aquelas discutidas ao longo da tese (e também de línguas distintas, como do português, (236) a (238) acima) podem, de fato, servir de indício da origem do experienciador no dativo como recipiente/alvo de eventos experienciais concebidos metaforicamente como causados externamente e de forma incontrolável.

Ademais, essa origem não controlável do experienciador dativo propicia contrastes de volicionalidade em diversas línguas. Como discutimos na seção 5.5 sobre a importância da volição em construções dativas (recorde os exemplos do urdu, malaiala (língua dravídica), além do próprio georgiano), observamos que em muitas línguas há contrastes no uso de casos de modo que o dativo é a contraparte que acarreta pouco controle ou volicionalidade, enquanto a marcação com nominativo ou ergativo (a depender da língua) denota maior volicionalidade e controle por parte do sujeito.

\subsection{Bidirecionalidade na conceitualização de eventos experienciais}

Como mencionamos, construções com dativos como (231) a (234) e, acreditamos, construções com locativos como (235), servem como indício de uma origem do experienciador como alvo/recipiente, ou mesmo como local, de um evento experiencial concebido como causado externamente e de forma incontrolável.

\footnotetext{
171 Interessantemente, construções como essas são também usadas em relação a fenômenos naturais, atestando para o fato de que concebemos eventos emocionais nessas construções como forças externas sobre as quais não temos controle, tal como em fenômenos naturais que podem ocorrer de forma imprevisível e sem nosso controle, observe: 'veio uma baita chuva ontem', 'de repente bateu um vento e levou tudo', 'deu uma esfriada de repente'.
} 
Note que o alcance dessa observação vai além de uma estrutura causal tal como usualmente se concebe na literatura.

Por exemplo, na literatura (cf. Miura (2015) para uma revisão, com base no caso do inglês antigo e médio), costuma-se estabelecer uma conexão entre causalidade e o desenvolvimento de verbos impessoais (dos quais, em muitas línguas, figuram verbos de emoção). No inglês, por exemplo, é argumentado que verbos como love e hate não se comportariam como impessoais na história do inglês justamente por serem estativos. Enquanto outros verbos na história do inglês, que teriam uma leitura ou uso causativo, seriam atestados em construções impessoais. ${ }^{172}$

Construções impessoais, no campo dos verbos experienciais, têm diversos paralelos com as construções dativas sob foco, já que normalmente apresentam um verbo conjugado na terceira pessoa e um experienciador marcado como objeto que possui certos comportamentos associados a sujeitos.

Ainda que interessante, para o presente estudo, essa correlação apontada em relação a verbos impessoais e causalidade, a nossa observação no primeiro parágrafo vai além do que se considera normalmente como 'causativas', levando em consideração a forma como concebemos eventos experienciais metaforicamente como causados externamente, por exemplo, como forças em um evento de dinâmica de forças.

Como argumentado por Kövecses (2005), uma metáfora mais geral observada na conceitualização de eventos experienciais é a de que EMOÇÕES SÃO FORÇAS que acometem o experienciador, usualmente salientando o aspecto de que o experienciador não tem controle sobre a experiência.

Dessa forma, essa conceitualização está presente em expressões que vão além da consideração das estruturas causais normalmente divisadas para esse tipo de evento (como 'ele quebrou o vaso'), como é possível observar pelos próprios exemplos discutidos na seção anterior do estudo de Kövecses (2005), em que muitos deles, inclusive, têm o experienciador como sujeito e ainda sim instanciam a metáfora mais geral identificada pelo autor.

Embora essa metáfora, como foi discutido, possa ter diversas manifestações, é interessante focarmos especificamente na questão de que eventos experienciais são

172 Observe, no entanto, como aponta Miura (2015), que há exceções a essa correlação entre causalidade e construções impessoais: o verbo listen é um caso de verbo que é atestado em usos impessoais desde o inglês antigo, mas que não apresenta leituras causativas. 
frequentemente concebidos metaforicamente como causados externamente, como eventos incontroláveis.

Em um evento como 'ele/isso me assustou' codificado pela construção transitiva, o aspecto de significado experiencial que se poderia dizer mais básico é justamente o de que esses eventos são concebidos metaforicamente como causados externamente (e sobre os quais não se tem controle), sendo usual que a causa tenha maior proeminência focal (embora não seja a regra).

Construções experienciais como 'ele/isso me assustou' são tidas como exemplos típicos de construções causais à semelhança de eventos como 'ele quebrou o vaso' na medida em que se consideram principalmente aspectos sintáticos. No entanto, a codificação por meio da construção transitiva pode obscurecer o fato de que construções experienciais, mesmo essas em que o estímulo é a causa, afastam-se do protótipo (o modelo de evento canônico).

Como citamos acima, a afetação sofrida pelo experienciador é diferente daquela de um objeto físico. Além do mais, em um evento experiencial, a trasmissão de energia de um participante a outro é concebida metaforicamente, já que não há contato físico (apenas mental) com a entidade. E como Grafmiller (2013) comenta, as emoções não são diretamente acessíveis a forças ou agentes humanos externos, são as ações intermediárias produzidas que afetam o experienciador. Tanto que essas ações e os efeitos que produzem podem ser ou não ser intencionais por parte do estímulo. Nuances essas de significado que podem ser mais ou menos salientadas a depender da construção e da situação.

Dessa forma, em um evento de dinâmica de forças físico, quando uma bola é chutada, esse objeto é diretamente submetido a uma força agentiva, o que não acontece com um evento experiencial, em que o fato de o experienciador sofrer os efeitos do evento depende de um contato mental prévio, sendo um contato mais indireto e ativo.

E como já dito, tendemos a entender experiências e conceitos abstratos, ainda que tão básicos quanto em nossa experiência no mundo, em termos de experiências e conceitos mais concretos. É de se esperar, dessa forma, que será explorada uma miríade de expressões e mecanismos linguísticos para se descrever essas situações, inclusive fazendo uso de mecanismos fortemente arraigados e gerais como construções transitivas.

Nessa perspectiva, um aspecto que é frequentemente ignorado quando se trata de construções experienciais causais é que há variação, por vezes na mesma língua, na 
forma como esses eventos experienciais, concebidos como causados externamente, são codificados. Em outras palavras, não são só construções transitivas (ou mesmo causativas mais marcadas) que codificam eventos experienciais em que a experiência é tida como causada externamente, e isso pode ser notado a partir da discussão acima e das exemplificações que foram dadas.

No português, por exemplo, uma construção como 'ele me deu um susto' é um tipo de sentença que codifica um evento experiencial concebido como causado externamente por um estímulo à semelhança da estrutura causal 'ele me assustou' .

É interessante notar o grau em que o aspecto não controlável do evento vai sendo salientando conforme a construção, e aqui citamos novamente os exemplos do português abaixo:

(239) De repente, me deu um sono/uma tristeza.

(240) De repente, me veio um sono/uma tristeza.

(241) De repente, me bateu um sono/uma tristeza.

Observe que, nesses eventos experienciais, é ainda mais enfatizada uma construção do evento experiencial como causado externamente e de forma incontrolável, tanto que, como comentado, são usados verbos de movimento e físicos (como 'bater'). Um dado importante é que há uma mudança sutil e um padrão na estruturação dessas sentenças: o pronome oblíquo referindo-se ao experienciador ocupa a primeira posição na sentença, e a emoção (que seria o sujeito de verbos como ‘bater’ e 'vir') é posposto ao verbo conjugado de terceira pessoa. Estruturação essa que lembra construções impessoais e também construções experienciais dativas.

E neste ponto, voltamos ao primeiro parágrafo desta seção. Argumentamos que as construções nos exemplos (231) a (235) servem como indício de uma origem do experienciador como alvo/recipiente, ou mesmo como local, de um evento experiencial concebido metaforicamente como causado externamente e de forma incontrolável.

Observe que, apesar de essas construções explorarem nuances de significado distintas (como a marcação diferenciada do experienciador, uso de verbos físicos ou de movimento), há a concepção metafórica, tal como observado em construções transitivas que codificam eventos experienciais causais, de um evento experiencial tido como causado externamente, como uma força sobre a qual o experienciador não tem controle. 
Um desenvolvimento comum que temos visto repetidamente ao longo da tese é o experienciador, na condição de objeto ou oblíquo, apresentar comportamentos sintáticos associados a sujeitos. Como pontua Malchukov (2008), o processo de reanálise, normalmente começando com a aquisição de propriedades de topicalidade (como primeira posição) e depois por propriedades sintáticas ou comportamentais, teria uma motivação transparente na medida em que reflete uma tendência funcional conhecida que alinharia o argumento mais proeminente na sentença com o sujeito.

Apesar de ser o caso que experienciadores sejam, de fato, participantes proeminentes por serem sempre sencientes, estímulos também têm características proeminentes associadas a papéis agentivos, como a causa do estado emocional.

Em contrapartida, ambos os participantes, experienciadores e estímulos, têm características mais 'passivas', o experienciador por ser não volitivo e sofrer uma experiência, e o estímulo, por ter a emoção dirigida a ele, sendo neutro nesses casos em relação a parâmetros de senciência e volicionalidade.

O que ocorre em muitos casos que temos observado até aqui é que os comportamentos sintáticos diagnósticos de sujeitos, na verdade, não recaem sobre apenas um participante em eventos em que o experienciador é marcado não canonicamente, sendo 'distribuídos' entre estímulo e experienciador (cf. seção 5.6 e exemplos). Daí muitas vezes a dificuldade em se rotular um ou outro como o sujeito ‘sintático' dessas construções.

Acreditamos, inclusive, que é complicado afirmar que a motivação é unicamente o experienciador ser o argumento mais proeminente funcional-discursivamente, pois se assim fosse o caso, não haveria uma tendência maior nas línguas a se codificar o experienciador sempre, ou na maior parte das vezes, como o participante mais proeminente em vez de codificá-lo como participante oblíquo ou objeto em primeiro lugar? Essa não parece ser uma tendência facilmente comprovável, já que como mencionamos, coexistem em grande parte das línguas, senão todas, construções que se assemelham a construções ObjExp e SubjExp. Além do mais, nem toda construção em que o experienciador é o objeto (normalmente causal) tem esse experienciador reanalisado como argumento mais proeminente.

Outro ponto importante apreendido por meio dos exemplos de (231) a (235) e de construções dativas do próprio georgiano que temos visto, é o fato de essas sentenças, pelo menos na origem, serem mais intransitivas, tanto que há a marcação do experienciador com um caso oblíquo e, por vezes, concordância com o estímulo/causa. 
As construções dativas em georgiano (principalmente as de morfologia de Classe IVe as construções com a vogal pré-radical -e-) são um caso particularmente interessante, pois atestam, como discutido, uma concordância de plural de terceira pessoa no georgiano antigo com o estímulo.

É importante pensar, de forma bem simplificada, em por que um participante atrairia, a princípio, tantos privilégios sintáticos para só depois eles serem 'cedidos' ao participante mais proeminente discursivo-funcionalmente da sentença.

Veja que, na GC, toda forma gramatical, assim como construções como um todo, carregam significado, ainda que esquemático. Assim, se havia um padrão em termos de construção em que o estímulo atraía mais privilégios sintáticos, como caso nominativo e concordância no verbo, é possivelmente indício de que havia uma motivação em termos de significado em que esse participante tinha uma maior proeminência focal no princípio. Em outras palavras, esse maior número de privilégios sintáticos no georgiano antigo era sintomático da maior proeminência do estímulo decorrente de um construal em que esse participante era possivelmente o foco primário.

Essa proeminência como foco primário não é gratuita. Em alguns casos, quando um participante é focado em detrimento de outro, uma parte diferente do evento pode também ter sido colocada em maior evidência, i.e., significando que houve uma escolha sobre qual porção daquele evento será mais perfilada. Observe que a conceitualização de qualquer evento é extremamente complexa, para fins de codificação linguística, o falante faz uma escolha (com base nos mecanimos convencionalizados que sua língua disponibiliza) sobre qual porção focalizar em determinado momento, sendo que uma série de fatores vão desempenhar um papel crucial como o contexto discursivo e social, o conhecimento enciclopédico, etc.

Naturalmente, estudos como o de Grafmiller (2013) são importantes justamente por levantarem fatores e correlações mais globais (como a natureza do estímulo) que desempenham um papel fundamental na diferenciação observada na codificação de eventos emocionais.

O recorte aqui feito, no entanto, visa especificamente entender a marcação dativa e a mudança observada em construções dativas (sendo o caso do georgiano emblemático) por meio da caracterização da conceitualização dessas construções em relação aos eventos experienciais no geral.

Observe, como descrito na seção 2.2.4 sobre domínios cognitivos na GC, que o conteúdo conceitual evocado por uma expressão abarca uma matriz complexa de 
domínios, não sendo o objetivo aqui (nem sendo talvez atingível) descrever cada domínio que é evocado por uma expressão, pois é importante salientar que diferentes emoções (como raiva, ódio, amor), assim como sensações físicas, evocam domínios certamente particulares a cada uma, levando em consideração concepções culturais e sociais sobre elas.

Ainda assim, como Kövecses (2005) pontua, alguns mapeamentos metafóricos (inclusive a metáfora mais geral proposta por ele) abrangem diversas emoções, parecendo mais gerais ao domínio das emoções (mas não exclusivas).

É nesse domínio experiencial que procuramos por uma conceitualização mais comum e fundamental e a partir da qual metáforas como aquela apontada por Kövecses como mais geral emerge. ${ }^{173}$

É importante esclarecer também que domínios não básicos, como definidos por Langacker (cf. seção 2.2.4), possuem níveis de complexidade e elaboração, sendo redutíveis a outros. Assim, acreditamos que certas conceitualizações envolvendo eventos experienciais podem abarcar uma série de outras concepções mais básicas. Na seleção de domínios, o que envolve construal, uma expressão pode evocar domínios diferentes ou porções de determinado domínio em vista de certo mapeamento metafórico.

Recorde que Kövecses (2005) (cf. seção 2.2.7) chama de framings essa diferente seleção de uma porção de um domínio fonte, por exemplo, a uma porção também específica de um domínio alvo.

Dessa forma, o que mais nos interessa no momento é entender quais porções ou aspectos estão justamente sendo mais ou menos focalizados na conceitualização de eventos experienciais e que estão sendo refletidos por meio de diferentes construções.

Assim, a escolha de diferentes entidades de um evento experiencial (se estímulo ou experienciador) como participantes mais proeminentes é um dos aspectos (e não o único) que acreditamos motivar a mudança observada em georgiano e outras línguas.

Outros aspectos se encontram, portanto, na forma como conceitualizamos eventos experienciais e nos mapeamentos metafóricos presentes, e é na caracterização dessa conceitualização que focaremos neste momento.

\footnotetext{
173 Langacker (1987, p.151) comenta brevemente sobre a coerência interna (em termos de parâmetros comuns) de um 'domínio emotivo', apontando algumas dimensões mais gerais, como a dimensão envolvendo o caráter mais positivo e negativo das emoções; e o aspecto mais ativo e quiescente de algumas emoções.
} 
Tanto a marcação diferencial do experienciador como dativo, locativo (ou mesmo possuidor em algumas línguas ${ }^{174}$ ), quanto o fenômeno observado nessas construções em que o experienciador adquire comportamentos sintáticos associados a sujeitos aponta, como já mencionado, para o fato de que experienciadores não são típicos pontos finais energéticos do evento (como pacientes o são) nem típicos iniciadores (como agentes o são) relativamente a eventos canônicos de transmissão de energia entre agente e paciente.

Esse é um ponto importante para a caracterização desse tipo evento, pois se eventos experienciais (e seus participantes) se afastam de uma interação canônica entre agente e paciente, é esperado que haverá possivelmente construções nas línguas em que esses eventos vão ser marcados diferencialmente. E por serem eventos abstratos de nossa experiência, ainda que básicos e fundamentais, há a tendência de serem concebidos com base em domínios mais concretos de nossa experiência, podendo haver mapeamentos metafóricos entre o domínio experiencial e domínios mais concretos.

Como foi explicitado na seção 2.2.6, Langacker (1991; 2008) divisa duas orientações básicas presentes nas línguas: a orientação de agente e a orientação de tema, cada uma reflete uma forma de dar proeminência linguística a um papel arquétipo de participante, o agente e tema. Embora as línguas façam uso de ambos os alinhamentos em menor ou maior grau, tanto um alinhamento quanto o outro pode ser estabelecido em uma língua como default.

Em línguas nominativo-acusativas, é a orientação de agente que é tida como default, em que o tipo mais canônico de sentença é a construção transitiva que codifica uma interação entre agente e paciente (como 'O João quebrou o vaso'), sendo o primeiro escolhido como foco primário (e normalmente marcado com o caso nominativo, sendo este o caso não marcado relativamente ao acusativo (que marca o tema)).

Em línguas ergativo-absolutivas, é a orientação de tema que é default, sendo que o tipo mais básico de sentença é um processo temático envolvendo um único participante (como 'O vaso quebrou'), que é escolhido como trajetor (e normalmente marcado com o caso absolutivo, sendo este o caso não marcado relativamente ao

\footnotetext{
${ }^{174}$ Moyse-Faurie (2011) nota que na língua xârâcùù, enquanto um experienciador nominativo descreve um estado emocional mais controlado, um experienciador marcado como possuidor expressa sentimentos mais profundos e incontroláveis, por exemplo, na sentença wâ-nâ xöru 'eu estou feliz', o experienciador é marcado como possuidor em que wâ significa 'interior/dentro' e nâ, a primeira pessoa do singular.
} 
ergativo (que marca o agente). Observe que um processo temático pode ser concebido autonomamente, i.e., sem evocar a fonte de energia.

Nessas duas orientações, há uma direcionalidade em relação ao fluxo de energia, na orientação de agente, o ponto de início de acesso mental é o agente que é a fonte de energia (e o paciente, o ponto final energético, i.e, o receptor da energia 'energy sink', como é chamado na GC), a transmissão de energia ocorrendo do agente ao paciente; na orientação de tema, o ponto de início de acesso mental é o tema, o ponto final energético, que pode ser concebido de forma autônoma, sendo que a fonte de energia, se evocada, é subsequentemente o ponto final de acesso mental. Observe que, apesar de concepções diferentes, a direcionalidade do fluxo de energia permanece, o agente, sendo ou não sendo evocado, continua sendo a fonte de energia.

O primeiro ponto de contraste que levantamos é que eventos experienciais não têm justamente uma direcionalidade única em termos de fluxo e transmissão de energia, como nota Croft (1993). Observe que experienciadores podem ser concebidos tanto como fontes de energia, quanto receptores energéticos do evento, do mesmo modo, estímulos também podem ser fontes de energia (como causas), assim como receptores.

Veja que na figura repetida abaixo de Croft (1993), há dois processos envolvidos em um evento experiencial: ao mesmo tempo que o experienciador precisa dirigir sua atenção ao estímulo, o estímulo ou alguma propriedade sua causa o experienciador a entrar em dado estado mental.

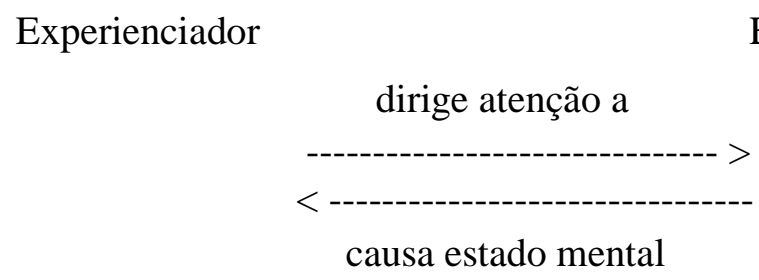

(CROFT, 1993)

Assim, para que o estímulo cause uma emoção no experienciador, é preciso que o experienciador dirija sua atenção ao estímulo, i.e., que o estímulo esteja no seu campo de consciência. Por isso, o evento seria bidirecional, não haveria uma direcionalidade única no fluxo de energia, o experienciador é tanto a fonte da energia, de onde ele dirige 
sua atenção ao estímulo, quanto o ponto final energético e receptor, na medida que o estímulo lhe causa ou provoca dada emoção.

Um indício dessa característica dual de eventos experienciais, nem como típicos eventos agentivos, nem como típicos eventos temáticos é a pervasividade com que a marcação diferencial (não canônica) desses eventos é encontrada nos diferentes tipos de alinhamentos observados tipologicamente e descritos acima.

É possível encontrar línguas tanto nominativo-acusativas com marcações diferenciais do experienciador (e das quais vimos diversos casos), quanto línguas ergativo-absolutivas como é o caso das línguas leste-caucasianas que vimos anteriormente, em que o experienciador é marcado com o caso dativo e casos locativos.

Interessantemente, em línguas ativo-estativas, inclusive, marcações diferenciais de eventos experienciais são também encontradas. ${ }^{175}$

Como foi discutido e exemplificado na seção 5.3.1, algumas línguas ativoestativas apresentam uma terceira marcação, da qual verbos experienciais (ou parte deles) fariam parte. Como argumentamos na seção 5.3.1 acerca dessas línguas, apesar da sobreposição desses predicados com outras marcações, há uma aparente homogeneidade no tipo de verbo que é encontrado com essa terceira marcação, sendo a maior parte, senão todos, verbos experienciais. ${ }^{176}$

Ao contrário de Croft (1993), que argumenta que eventos emocionais causais e incoativos não seriam bidirecionais (como os estativos), pois teriam uma direcionalidade única (o evento emocional causal, para o autor, envolveria transmissão de energia, induzindo uma mudança de estado), acreditamos que esses eventos (causais e incoativos emocionais) também seriam concebidos como bidirecionais.

De fato, pode-se argumentar que eventos experienciais são conceitualmente bidirecionais na medida em que experienciadores e estímulos não são nem típicos

\footnotetext{
175 Segundo alguns estudos (cf. Wichmann, 2008), em alinhamentos semânticos (como por vezes classificadas as línguas estativas), a valência dos verbos não seria um fator determinante, pois a motivação de marcação distinta se daria em razão da semântica lexical dos verbos, seja em termos de agentividade, aspecto lexical, estatividade, etc. Dessa forma, seria argumentado que categorias como sujeito e objeto não seriam determinantes, ou mesmo relevantes, para a organização dessas línguas (WICHMANN, 2008).

${ }^{176}$ Croft (1993) cita também alguns casos de línguas ativo-estativas que teriam uma terceira marcação, ou uma marcação 'neutra', como cupeño. Croft nota que na língua achém, verbos emocionais estariam 'espalhados' pelas diferentes marcações (uma ativa, estativa e variável), sendo frequentes na marcação variável. Esse dado é particularmente interessante, já que mostra um comportamento diferencial de verbos experienciais na medida em que não se 'encaixariam' propriamente nem em uma marcação nem em outra.
} 
iniciadores (fontes), nem típicos pontos finais energéticos (receptores), não havendo uma direcionalidade que se poderia argumentar intrínseca a esses eventos.

Observe que a metáfora mais geral observada por Kövecses em eventos experienciais é justamente decorrente dessa característica bidirecional, pois há um mapeamento entre uma porção perfilada do evento experiencial com um domínio mais concreto de nossa experiência envolvendo o arquétipo conceitual de dinâmica de forças, em que a emoção (ou metonimicamente suas causas) é concebida metaforicamente como causada externamente, como uma força que atinge o experienciador.

É nessa concepção metafórica que frequentemente eventos emocionais são codificados através de construções transitivas, havendo o que poderia parecer uma direcionalidade causal à semelhança de eventos canônicos. No entanto, como já argumentamos, ainda nesses casos, eventos experienciais se afastam conceitualmente de um evento canônico, sendo que essa concepção metafórica é observada em construções que são menos transitivas e que marcam diferencialmente o experienciador.

Observe que estímulos podem também ser marcados diferencialmente (cf. em especial a seção 5.4 sobre DOM), um caso interessante que já discutimos é o do português (e também de outras línguas que foram exemplificadas), em que emoções mais positivas são marcadas com 'por' 'João sente amor por animais'; e emoções mais negativas são marcadas por 'de' 'João sente raiva de cobras', cada qual dando proeminência a um aspecto do evento experiencial como bidirecional. ${ }^{177} \mathrm{Na}$ codificação com a preposição 'de', é perfilada justamente a porção da conceitualização do evento experiencial tido metaforicamente como causado externamente, possivelmente salientando o estímulo como responsável por suscitar uma emoção mais negativa. Já no caso de 'por', é perfilada a porção da conceitualização do evento experiencial em que a emoção surge a partir do experienciador em direção ao estímulo, enfatizando um evento de maior empatia ao estímulo.

Ainda, um ponto adicional a favor dessa análise, é o fato de experienciadores marcados não canonicamente passarem a adquirir maior proeminência conceitual como no caso das construções dativas no georgiano. Como foi dito acima, acreditamos que uma motivação desse fenômeno decorre da forma como conceitualizamos eventos experienciais: experienciadores não são intrínsecos pontos finais da energia, tornando-se

\footnotetext{
177 Interessantemente, essas expressões do português, assim como outros casos de outras línguas discutidos na seção 5.4, evocam como parte de seu conteúdo conceitual, a dimensão apontada por Langacker (1987) como sendo uma das possíveis dimensões do domínio emotivo, i.e., a dimensão que posiciona emoções como negativas e positivas.
} 
natural que possa haver uma mudança de perspectiva em que seu papel mais iniciador como fonte (aquele que dirige a atenção ao estímulo) passe a ganhar mais proeminência na construção do evento emocional, essa mudança de perspectiva refletindo-se na atração de mais privilégios sintáticos.

Como dissemos, a conceitualização de um evento é complexa, e para fins de codificação linguística, certos aspectos podem ser mais focalizados do que outros. Quando é focada a porção do evento experiencial em que o estímulo causa a emoção no experienciador, uma série de outros aspectos são também salientados em maior ou menor grau, como o não controle sobre o evento experiencial por parte do experienciador, pois é acentuado justamente que aquela emoção metaforicamente vem externamente em direção ao experienciador e o atinge. É interessante observar que o frequente uso de verbos de movimento e de força física codificando essa concepção é indício disso, de que não temos controle sobre eventos externos que recaem sobre nós e nos engolfam.

Os significados das expressões, no entanto, não são imutáveis. Uma mudança frequente, dessa forma, é o deslocamento de perspectiva de um aspecto da conceitualização de eventos experienciais para outro, como a mudança para uma maior saliência à porção do evento em que o experienciador é o iniciador do evento e dirige sua atenção (e, como possível consequência conceitual, sua emoção) ao estímulo.

Observe que nesses casos sempre parece haver a opção de marcar o estímulo de alguma forma. Em muitos casos, como o georgiano, apenas ocorre a 'inversão', em que o estímulo continua marcado com o nominativo (mas perde outros privilégios). Em outros casos, no entanto, o estímulo pode ser marcado com um caso oblíquo, a construção impessoal do latim, me pudet, é um exemplo, em que o estímulo é marcado através do genitivo.

Uma consequência da maior proeminência atribuída à porção do evento em que o experienciador dirige sua atenção ao estímulo é a frequente construção do evento experiencial como a surgir do experienciador, tornando-se o locus de onde a emoção surge. Observe que o que passa a ser mais salientado não é a emoção causada externamente, mas a emoção como a surgir do experienciador, nesse ponto, ele é construído como o iniciador que pode dirigir, então, aquela emoção ao estímulo.

Uma consequência dessa mudança de perspectiva é que o experienciador parece herdar o não controle/volicionalidade e afetação (no sentido de ser afetado emocionalmente) característicos do evento causado externamente. Essa herança é 
bastante aparente nas construções que temos visto em que o experienciador marcado não canonicamente passa a adquirir maior proeminência, o próprio georgiano é um exemplo, em que o dativo carrega fortemente o sentido de não voliconalidade e afetação.

Note que mesmo em construções que denotam eventos experienciais que não passaram por essas mudanças de perspectiva, há características da bidirecionalidade apontada. Verbos emocionais incoativos, por exemplo, são um caso em questão. Em muitas línguas, verbos emocionais são marcados com a voz média (cf. discussão na seção 6.2) e, acreditamos, que há uma razão para haver essa marcação comum entre eventos típicos médios e eventos emocionais, sendo justamente o fato de que nesses eventos a diferenciação entre ponto final energético do evento e iniciador são inexistentes.

Essa não diferenciação de participantes característica da voz média favorece que eventos emocionais sejam codificados dessa forma, pois experienciadores não são típicos pontos finais energéticos nem típicos iniciadores (fontes). E como apontado, na codificação de eventos, os falantes fazem uso dos recursos convencionalizados disponíveis para codificar diferentes significados. Dessa forma, a contrução média com eventos emocionais parece salientar o aspecto em que a emoção surge a partir do experienciador, por isso a frequente característica incoativa desses eventos. Novamente, mesmo nesses casos, há a opção de marcar o estímulo para o qual a emoção é dirigida, normalmente de forma oblíqua, o que mostra que o aspecto primário do construal dessas construções é salientar a porção em que o experienciador é o iniciador do evento (e dirige sua atenção).

Observe que essa característica bidirecional pode ficar menos em evidência quando construções usadas para codificar eventos mais canônicos são utilizadas para também codificar eventos menos prototípicos, como eventos experienciais.

Assim, casos de eventos emocionais marcados de forma mais canônica como 'João ama Maria' (cf. discussão na seção 6.2), em que é utilizada uma construção transitiva - recurso aliás que frequentemente é usado nas línguas (podendo coexistir inclusive com outras construções não canônicas marcando eventos experienciais) apontam não para uma descaracterização de eventos experienciais como bidirecionais, mas sim mostram que nas línguas há padrões construcionais fortemente arraigados e que podem atrair e serem utilizados para codificar uma miríade de eventos periféricos com significados distintos. 
Nas línguas, pode haver tanto pressões do sistema que tentam generalizar padrões minoritários em um processo de analogização a padrões altamente arraigados, quanto processos de especialização, em que uma construção pode gradativamente se distanciar do padrão para acomodar sentidos mais específicos. ${ }^{178}$

No primeiro caso, temos processos extremos como o ocorrido com algumas construções impessoais experienciais no inglês (cf. Miura (2015)), em que elas foram completamente absorvidas pelo padrão transitivo.

No segundo caso, temos exemplos do próprio georgiano, em que a construção dativa experiencial é um caso de forte especialização se compararmos a outras construções semelhantes com dativos, como construções de transferência. Como discutimos na seção 5.6, diacronicamente no georgiano, a construção dativa com verbos experienciais foi uma das primeiras a ter atestada a concordância no verbo de terceira pessoa plural com o dativo, o que foi se fortalecendo ao longo da história da língua, sendo obrigatória no georgiano moderno. Em contraste, concordância com o dativo de terceira pessoa plural em verbos de transferência é apenas marginalmente atestada.

Outro indício da especialização da construção dativa experiencial no georgiano é que seu comportamento através das Séries é uniforme se comparado ao comportamento de outras Classes verbais (a exceção de verbos de morfologia de Classe II), mantendo em todas as Séries marcação igual de conjuntos de afixos de concordância e caso gramatical.

Ademais, mesmo em casos de generalizações como em 'João ama Maria' em que é utilizada uma construção transitiva, esses eventos continuam a ser baixos em transitividade e seus participantes continuam a ser casos marginais dos protótipos de agente e paciente em uma interação canônica (já que o sujeito experienciador não é agentivo e o estímulo não é um típico paciente no sentido de sofrer uma mudança de estado).

\footnotetext{
178 É interessante notar que padrões 'minoritários' tendem a resistir a pressões analógicas se semanticamente coerentes. Fedriani (2014, p.243) descreve, seguindo Barddal (2008): "[...] both broad and specific schematic constructions are expected to be productive over time, their difference in productivity being one of degrees of semantic generality. Broad schematic patterns such as the transitive one are likely to attract new types irrespective of semantic constraints, thus leading to generalization processes; lexically-filled patterns, by contrast, are expected to match semantically related verbs and to undergo constructional specialization. This means that high type frequent constructions will either be diachronically stable, if semantically coherent enough, or diminish and even disappear if they are not sufficiently schematic to ensure a high degree of lexical strength, and resist constructional switches toward more productive competing structures."
} 
De fato, uma característica da conceitualização de eventos experienciais e que influencia aspectos de sua característica bidirecional é o pouco controle e volicionalidade do experienciador sobre a emoção. Observe que esse parece ser o valor mais prototípico, nada impedindo que eventos experienciais sejam construídos como mais volitivos ou como experiências mais ativas dependendo do contexto e de outros fatores (cf. o estudo de Grafmiller (2013) discutido na seção 3.2 e a seção 5.5 sobre casos de construções mais marcadas de volicionalidade relativamente a construções experienciais dativas no georgiano).

De modo geral, como vimos nas seções 5.5 e 5.8, em muitos casos, a coexistência de duas marcações (uma mais canônica e outra menos) pode resultar em significados mais especializados de cada uma, como maior ou menor grau de volicionalidade por parte do experienciador, sendo normalmente aquele marcado mais canonicamente que terá uma maior volicionalidade e o marcado não canonicamente, aquele com menor controle ou volicionalidade.

Note que transitividade, por ser uma noção escalar, não é uma questão absoluta, havendo graus relativamente a diversos parâmetros. Recorde a discussão sobre verbos de percepção na seção 5.3.2. Um caso particularmente interessante que vimos é o do verbo 'ver' e 'olhar' em georgiano, mesmo os dois tendo o experienciador marcado canonicamente na língua, há uma diferença entre um significado de uma percepção mais inativa versus ativa (dirigida) do evento experiencial, sendo o segundo marcado mais intransitivamente do que o primeiro na medida em que o estímulo é marcado diferencialmente.

Como alguns autores notam (cf. Kemmer (1993) e Fedriani (2014)), verbos de percepção teriam uma propensão maior a aparecerem com marcação mais canônica (relativamente a verbos de emoção e físicos), pois seriam mais frequentemente construídos como reagindo ativamente a um estímulo, estando mais conscientes dele e tendo um envolvimento mais racional (como em alguns casos de eventos de cognição), comparadamente a eventos emocionais e físicos que seriam mais incontroláveis.

Observe que mesmo nesses casos, de percepção ativa e inativa (e também eventos de cognição), é possível perceber a base conceitual bidirecional de eventos experienciais, tanto que em uma percepção ativa é salientado o aspecto de que o experienciador dirige sua atenção ao estímulo (em alguns casos de forma mais volitiva), parecendo ser mais focalizado o fato de o experienciador dirigir sua atenção do que ver de fato o estímulo; já na percepção inativa, há o sentido de que o estímulo aparece de 
forma menos controlável no campo de consciência do experienciador, como vindo em sua direção (como em expressões menos controláveis que vimos no decorrer da tese em línguas distintas como 'vir à memória', 'bater o olho', 'parecer a alguém' (no sentido de 'achar, pensar'), etc.

Antes de continuarmos nossa argumentação a respeito da bidirecionalidade de eventos experienciais, é chegado o momento de discutirmos um ponto fundamental que ainda não foi esclarecido a respeito da conceitualização de eventos experienciais e que nos propusemos a explicar desde o início desta tese: por que a marcação dativa ou mesmo locativa do experienciador? E por que essa frequente semelhança com a marcação de eventos como de posse?

Como deve ter ficado evidente, esse tipo de marcação, utilizando-se principalmente o caso dativo, é comum em línguas de famílias tipologicamente bem diversas. O que pode indicar que essa marcação em particular decorre de semelhanças na forma como conceitualizamos eventos experienciais.

O que se poderia sugerir, a princípio, é que haveria um mapeamento metafórico entre o domínio mais abstrato experiencial e o domínio mais concreto espacial. ${ }^{179}$

E pelo o que temos visto até aqui, parece haver realmente uma correlação conceitual entre esses dois domínios, sendo o experienciador construído frequentemente como o locus espacial da emoção como foi notado diversas vezes.

No entanto, para se ter um entendimento mais aprofundado desse mapeamento conceitual e compreender como ele se relaciona com a conceitualização bidirecional que começamos a discutir acima e com os dados de modo geral, é preciso retomarmos algumas considerações mais gerais.

Em particular é importante compreender o papel conceitual que ocupa a noção de local na conceitualização de eventos e, consequentemente, na gramática das línguas, para isso, é pertinente relembrar a discussão na seção 6.5.

\footnotetext{
179 Linguistas de diferentes orientações teóricas já notaram a importância e pervasividade do domínio espacial na construção de eventos experienciais, Landau (2010) é um deles (cf. seção 3.2). A análise do autor é voltada à hipótese de que experienciadores na posição de objeto seriam sintaticamente locativos, i.e., indiferentemente de haver ou não razões conceituais para considerar experienciadores na posição de objeto como locativos mentais, o autor parte exclusivamente da premissa de que argumentos experienciadores são locativos sintáticos e por isso apresentariam características especiais.
} 


\subsection{Locais e sua conexão conceitual com experienciadores e com a noção de bidirecionalidade}

Como foi discutido em relação às línguas leste-caucasianas, há uma proximidade entre locativos e dativos, sendo o próprio dativo um caso que se poderia dizer intermediário ou limítrofe entre um caso mais 'gramatical' e casos locativos per se e adposições. Sendo assim, a exposição na seção 6.5 pode trazer algumas pistas sobre a razão conceitual da frequente codificação de experienciadores por meio de casos dativos, locativos e adposições espaciais (como em exemplos do português, cf. (34)).

De um lado, na esfera ativa, que é central de um ponto de vista egocêntrico, a oposição que se verifica em uma sentença canônica é entre os arquétipos de agente e paciente, representando um contraste máximo em termos de interação, ação, mudança e força.

Do outro, há a esfera circunstancial, mais periférica, abrangendo cenários, locais, situações estáticas e objetos com propriedades estáveis. Uma construção básica dessa esfera constitui o uso do verbo ser/estar com um complemento especificando uma propriedade de determinada entidade ou um local espacial.

Como Langacker pontua, mesmo no caso de situações estáticas, a esfera ativa lança sua influência. Por exemplo, as preposições (que justamente costumam marcar esse tipo de relação estável) abrangem um ponto intermediário entre as esferas ativa e circunstancial, já que por mais que designem situações estáticas, elas seriam usualmente concebidas em relação à interação e movimento.

$\mathrm{O}$ que a marcação oblíqua do experienciador parece mostrar é que eventos experienciais também ocupam, de certa forma, um lugar intermediário entre as esferas ativa e circunstancial, já que oscilam entre interação e mudança e situações estáticas em que pessoas têm certas propriedades emocionais e sentimentos estáveis. De fato, como vimos na seção 6.2, eventos emocionais são frequentemente codificados através da cópula nas línguas.

Essa oscilação é bastante aparente no próprio uso do dativo, como vimos, dativos têm características de casos mais 'gramaticais' (que codificam normalmente os protótipos de uma interação canônica na esfera ativa), sendo o evento de transferência o padrão de seu uso mais gramatical, já que nesses casos o dativo pode acionar concordância no verbo em algumas línguas, além de ser um participante usualmente 
obrigatório. No entanto, como vimos na seção 6.4 sobre as línguas leste-caucasianas, a origem espacial do dativo pode ter sua base em locativos ou mesmo em adposições.

Assim, o experienciador parece encontrar no dativo uma marcação diferencial que reflete a característica intermediária de eventos experienciais.

Um aspecto, portanto, a ser explorado é justamente como noções próprias da esfera ativa como interação e movimento estariam presentes na conceitualização de eventos experienciais em que o experienciador tem uma marcação usualmente reservada a elementos mais estáticos ou periféricos (como adposições ou locativos).

Por essa perspectiva, mesmo eventos estáticos seriam frequentemente vistos de um ponto de vista egocêntrico, noção essa que nos ajudará a compreender o papel do domínio espacial na conceitualização de eventos experienciais, manifestado linguisticamente em uma variedade de formas.

A começar pelas construções em que o evento experiencial é metaforicamente concebido como causado externamente. Observe que, em muitas dessas construções, é dada proeminência à emoção ou às suas causas de forma a salientar justamente o sentido de que o evento experiencial recai sobre o experienciador. Mesmo nesses casos, esse tipo de evento é visto através de nossa perspectiva egocêntrica a partir do extremo da esfera ativa, tanto que verbos de ação e de movimento são frequentemente utilizados em sua codificação, resultando em construals em que emoções 'vêm' em direção ao domínio do experienciador, 'saem' de seu domínio, são 'recebidas' pelo experienciador, etc.

Essa perspectiva egocêntrica é particularmente evidente quando o experienciador é marcado com o caso dativo (locativo ou mesmo através de adposições), como, por exemplo, (231) a (235), (230), (e mesmo exemplos do português de (236) a (238)), em que mesmo o experienciador sendo tido como um local ou repositório 'estático’ da emoção, o evento é visto a partir de interação e movimento.

Essa característica dual também é observada em relação aos eventos mais estativos aspectualmente. Como é notado na literatura, construções com experienciadores no dativo, e também construções impessoais, denotam normalmente eventos estativos. No entanto, ainda que estativos, esses eventos, como aqueles apontados no parágrafo anterior, são concebidos a partir de interação e movimento. 
E o domínio espacial tem um papel particularmente importante. ${ }^{180}$

Ainda que a influência da esfera ativa, e noções próprias como interação e movimento, seja mais ou menos saliente a depender do evento (cf. nota 167 sobre os adjetivos), seu papel pode ser apreendido em muitas das construções de eventos experienciais, particularmente aquelas envolvendo mapeamentos no domínio espacial.

Como notamos em diversos momentos ao longo da tese, o experienciador é frequentemente concebido como o local espacial onde ocorre a emoção e de onde ela surge, sendo esse local, por vezes, metonicamente tido como uma parte de seu corpo (cf. seção 5.3.1).

Esse mapeamento metafórico envolve diretamente uma concepção bidirecional desses eventos, já que na proporção em que experienciadores são construídos como locais ou alvos/recipientes para onde a emoção causada é dirigida, experienciadores são também construídos como os locais onde essa emoção se dá e surge (podendo ser dirigida ao estímulo), possibilitando que esses experienciadores possam ser concebidos tanto como pontos finais energéticos (usualmente em eventos experienciais causados externamente) quanto como fontes de energia (usualmente em eventos em que o experienciador é o foco primário).

Essa estrutura conceitual é particularmente evidente em codificações em que o experienciador é marcado diferencialmente. Construções dativas constituem um indício produtivo dessa estrutura, especialmente por apresentarem frequentemente nas línguas uma mudança de foco de um participante a outro, sendo a atração de comportamentos sintáticos sintomática dessa mudança.

O fato de experienciadores serem marcados através de casos espaciais ou mesmo por meio de outras construções envolvendo alguma concepção espacial revela não que concebemos experienciadores como entidades puramente estáticas que 'contêm' emoções ou propriedades emotivas, mas que concebemos experienciador e sua experiência em relação à interação e movimento no espaço.

180 Como Lakoff (1992) nota, metáforas envolvendo espaço como ESTADOS SÃO LOCAIS (regiões delimitadas no espaço), MUDANÇAS SÃO MOVIMENTOS (para dentro ou fora de regiões delimitadas), dentre outras, são bastante comuns na conceitualização de eventos em geral, sendo, inclusive, notadas em relação a eventos experienciais como nas expressões 'He is in love', 'Ele está em depressão' em que o estado de 'amar' é conceitualizado como uma região delimitada no espaço; ou 'Ele entrou em depressão', 'Ele conseguiu sair da depressão' em que a mudança para o estado de depressão ou fora dele é sinalizada através de um verbo de movimento para dentro (ou fora) de uma região delimitada. Como Langacker (2010) menciona, a esfera circunstancial é vista como um palco para a ação humana, de forma que nos movimentamos por locais e os ocupamos, em um mapeamento metafórico para um domínio mais abstrato, emoções são construídas como locais por onde passamos, podemos permanecer e ocupar ou mesmo sair. 
Algumas noções arquetípicas aterradas em nossa experiência são fundamentais para entender esse aspecto interativo, tais como a noção de proximidade e contato com objetos no espaço, separação e afastamento de objetos, um objeto em um local, container e conteúdo, dentro (inclusão) e fora, etc.

Observe que ao concebermos experienciadores como locais, há a concepção de pessoas como regiões delimitadas com interiores também como regiões bem delimitadas (como mente, coração, estômago, etc), estabelecemos, assim, relações de dentro (inclusão) e fora (o externo a essas regiões). Ademais, experienciadores são tidos frequentemente como containers que servem para reter conteúdos, i.e., emoções e sensações físicas.

Decorre daí uma série de expressões que são utilizadas pelas línguas para se referir e diferenciar o que ocorre dentro de nossa esfera íntima do externo ou ainda enfatizar a concepção de experienciadores como containers que são preenchidos por emoções, o extremo da exacerbação sendo o momento em que as emoções extrapolam a região delimitada.

Observe, por exemplo, a gradação de interiorização à exteriorização em expressões experienciais do português (algumas delas vistas nas seções 2.2.7 e 3.2): 'no fundo, eu estava cansado', 'eu senti um profundo cansaço', 'havia um medo dentro de mim', 'isso nos enche de medo', 'estamos cheios de medo', 'estou cheio/farto dessa situação', 'ele estava explodindo de raiva', 'ele despejou toda sua raiva', 'ele está fora de controle', 'ele está fora de si'.

Em outras línguas, notam-se ainda processos de gramaticalização envolvendo noções de inclusão e interior. Na língua xârâcùù (cf. nota 174), expressões que expressam sentimentos mais profundos e incontroláveis têm o experienciador marcado como possuidor. Por exemplo, em uma sentença como wâ-nâ xöru 'eu estou feliz', o experienciador é marcado como possuidor em que wâ significa 'interior/dentro' e nâa, a primeira pessoa do singular (MOYSE-FAURIE, 2011).

Em yorùbá, em uma sentença denotando um evento experiencial como inú bi mi 'eu sinto raiva', bi significa 'raiva', mi codifica a primeira pessoa do singular e inú significa 'dentro (gramaticalizado de 'barriga')', literalmente 'raiva dentro de mim' (cf. Croft (1993); Dingemanse (2006)).

Essa concepção de inclusão e de container parece enfatizar justamente o fato de eventos experienciais acontecerem na esfera íntima do experienciador, sendo apenas sentidos pelo experienciador ou 'dentro' deles em contraste com o 'externo'. 
Algumas línguas, inclusive, indicam através de marcas de evidencialidade esse acesso privilegiado que experienciadores têm do que acontece em seu interior. Em casos de egoforicidade, ${ }^{181}$ por exemplo, esse acesso privilegiado é codificado linguisticamente (cf. FLOYD et al, 2018). Em newar de Katmandu (língua tibetana), um predicado egofórico indicando temperatura como ciku(l)- 'estar frio' ocorre com um experienciador no dativo. Quando adicionada, no entanto, a forma causativa -kal-, a interpretação é de que o experienciador externalizou uma evidência de seu estado interior como, por exemplo, através de tremores ou mesmo um fingimento de estar com frio. Esse comportamento externalizado (sinalizado pela marca causativa) é tido como um conhecimento mais público, normalmente confirmado por evidência visual e por um acesso não egofórico (não privilegiado) (HARGREAVES, 2018).

Interessantemente, a nossa esfera de controle não somente abrange o que acontece 'dentro' de nós, mas o que está próximo, contíguo ou em contato, refletindo mais evidentemente uma perspectiva egocêntrica envolvendo interação e movimento.

E os exemplos são diversos, experienciadores podem tanto ser tidos como recipientes quanto alvos, salientando-se a noção de proximidade ou mesmo contato com a emoção. Esse aspecto é particularmente visto nas construções que vimos ao longo da tese de diferentes línguas, em que predicados (de movimento ou força física) como 'vir', 'ir', 'deixar', 'dar', 'bater', 'cair sobre' implicam algum tipo de contato ou proximidade com o experienciador (no caso de sentir a emoção ou sensação física) e distância e afastamento do experienciador (no caso de ele não mais sentir).

Observe que, além de movimento, a noção de interação também pode ser apreendida do mapeamento metafórico entre proximidade espacial e esfera de controle experiencial na medida em que, como Langacker (2009) comenta sobre posse (cf. seção 5.3.4.1), esse mapeamento envolveria a concepção de que proximidade espacial a algo permitiria seu acesso e controle, i.e., é a partir de alguma coisa estando próxima a nós espacialmente que seria possível interagir com ela ou usá-la, ou metaforicamente, experienciá-la.

Em português (assim como em haussá, uma língua afro-asiática, cf. exemplo 202), a emoção pode ser marcada com uma marca comitativa em certas expressões

\footnotetext{
181 Egoforicidade se refere à gramaticalização de marcas envolvendo algum tipo de conhecimento pessoal em uma situação descrita, sendo marcas egofóricas tipicamente encontradas com sujeitos de primeira pessoa em declarativas e de segunda pessoa em interrogativas, refletindo o fato de que falantes possuem mais conhecimento sobre seus próprios assuntos, mudando de autoridade para 0 destinatário em perguntas (FLOYD et al, 2018).
} 
experienciais, em port.: 'eu estou com calor/raiva'. Essa marcação é particularmente interessante, pois mostra que a emoção ou sensação está sendo concebida como acompanhando o experienciador, isto é, estando próxima a ele. Em tsez, língua lestecaucasiana, há um indício dessa relação entre proximidade espacial e marca comitativa, já que como nota Comrie \& Polinsky (1998), a marca orientacional significando 'perto', também tem a interpretação secundária de comitativo na língua.

Dessa forma, o 'acompanhamento' ou proximidade da emoção ou sensação junto ao experienciador é metaforicamente tida como pertencente à sua esfera de controle, significando, assim, que o experienciador está sentindo aquela emoção ou sensação.

Essa esfera de controle do experienciador carrega semelhanças com a noção de domínio definida por Langacker na GC (cf. seção 5.3.4.1 sobre posse e seção 6.3 a respeito da análise de Maldonado envolvendo a noção de domínio). ${ }^{182}$

E resulta daí, acreditamos, a conexão próxima nas línguas entre eventos de posse e experienciais. Inclusive, em algumas línguas como vimos, experienciadores são marcados como possuidores.

Como foi exposto na seção 5.3.4.1 sobre a análise de Langacker sobre a relação de construções existenciais, locativas e de posse, haveria nessas construções o envolvimento da capacidade cognitiva de ponto de referência, em que o participante, servindo como ponto de referência, seria utilizado para localizar o alvo dentro de um domínio de busca.

No caso de posse envolvendo construções locativas e existenciais (como o caso do japonês discutido), o domínio espacial é metaforicamente tido como o domínio de experiência do falante, como mencionado acima, metaforicamente, proximidade espacial permite acesso e controle de determinada coisa por parte do possuidor.

Dessa forma, a frequência com que construções locativas (com a cópula, por exemplo) são encontradas com eventos experienciais e mesmo de posse não significa necessariamente que esses eventos são vistos puramente como estáticos, onde experienciadores 'contêm' propriedades emotivas estáveis, mas sim carregam um

\footnotetext{
182 Dabrowska (1997), em sua análise sobre o dativo no polonês, também traz noção semelhante. Para a autora, o dativo marcaria o papel de 'pessoa alvo' (que abarcaria também o papel mais específico de experienciador), um indivíduo que seria afetado por uma ação, processo ou estado que se daria em sua esfera pessoal. Essa 'esfera pessoal' abrangeria pessoas, objetos, locais e fatos suficientemente associados a um indíviduo, de modo que mudanças ocorridas nessa esfera o afetariam diretamente. Assim, experienciadores seriam participantes afetados na medida em que alguma experiência ocorreria em sua esfera de consciência, i.e., uma região da esfera pessoal da pessoa alvo onde sentimentos, pensamentos e sensações seriam experienciados.
} 
aspecto interativo, em que emoções são localizadas relativamente à esfera de controle ou mesmo de consciência do participante, podendo essa esfera ser seu corpo como container (ou metonimicamente uma parte de seu corpo) ou mesmo como proximidade ou contato ao seu corpo.

Observe que tanto possuidores quanto experienciadores marcados através de construções dativas (ou locativas) salientam a afetação desse participante, havendo justamente a concepção de que esse domínio espacial é metaforicamente tido como o domínio experiencial do participante, i.e., o fato de algo estar, ou se alterar, em sua esfera de controle ou de consciência, acarreta uma maior afetação desse participante.

Interessantemente, como nota Langacker (2009) para o japonês, observa-se em construções dativas de posse, assim como experienciais, uma mudança de proeminência focal em que o experienciador ou possuidor adquire características sintáticas normalmente atribuídas a sujeitos.

Langacker pontua para construções de posse (cf. seção 5.3.4.1) que essa mudança se daria em razão de um deslocamento de perfil em que é salientada a relação em que $T$ está localizado em relação a $R$ para uma relação em que $R$ controla $T$, instigando uma mudança focal em que $\mathrm{R}$ se tornaria o foco primário.

No caso de construções dativas experienciais, em que mudanças similares de foco são observadas, essa noção de esfera de consciência parece se alinhar com a conceitualização bidirecional desses eventos na medida em que diferentes aspectos podem ser perfilados (tal como em eventos de posse). No caso em que o evento experiencial é concebido como causado externamente, a emoção (ou suas causas) entram ou vão em direção ao domínio do experienciador, normalmente de forma incontrolável, já em casos em que o experienciador é tido como fonte de energia, é salientado o aspecto em que o experienciador dirige sua atenção ao estímulo, de forma que esse estímulo (ou a emoção despertada), consequentemente, é concebido como estando em sua esfera ou domínio de consciência.

Nesta última concepção, o experienciador tende a ser construído como foco primário, fortalecendo seu papel mais iniciativo, como é salientado em alguns casos de construções com verbos de cognição e percepção.

Dessa forma, embora o fato de a animacidade de experienciadores e possuidores (participantes naturalmente salientes de um ponto de vista humano) ser um fator importante na frequente mudança observada nessas construções, em que o nominal dativo passa a receber maiores privilégios sintáticos sintomáticos de sua saliência 
conceitual como foco primário, há também aspectos da conceitualização de eventos experienciais que são diferentemente perfilados e que favorecem (mas não necessariamente limitam) que esses participantes ganhem maior proeminência.

Esses diferentes aspectos perfilados refletem a natureza bidirecional de eventos experienciais, isto é, esses eventos não teriam uma direcionalidade única no sentido de transmissão de energia de um participante a outro. Em eventos físicos canônicos, observa-se que há uma direcionalidade na transmissão de energia, em que um agente, o ponto de início de acesso mental e fonte de energia, causa uma mudança de estado em um paciente, o ponto final e receptor de energia. Em casos de eventos absolutos, a fonte de energia não é concebida, sendo o processo temático, o ponto inicial de acesso mental e o ponto final energético do evento, que é conceitualizado.

A assimetria entre trajetor e marco também é menos 'previsível' no caso de eventos experienciais, como Langacker (1987) nota a respeito de eventos experienciais em contraste com eventos físicos:

In contrast, verbs of perception and mental or emotional attitude provide less basis for an figure/ground asymmetry (for example, does a viewer's gaze move towards a perceived object, or does a visual signal travel from the object to the viewer?); the choice of subject is consequently more flexible and depends on the image selected to structure the scene. (LANGACKER, 1987, p.234).

No caso de eventos experienciais, como na figura abaixo, tanto experienciador quanto estímulo podem ser concebidos potencialmente como fontes de energia ou pontos finais energéticos a depender de qual aspecto salientado: o estímulo pode ser a fonte de energia na medida em que causa o evento experiencial no experienciador ou o ponto final energético como aquele ao qual a atenção do experienciador é dirigida. Da mesma forma, o experienciador pode ser a fonte de energia ao passo que dirige a atenção para o estímulo, mas também o ponto final energético já que é o receptor da experiência. 


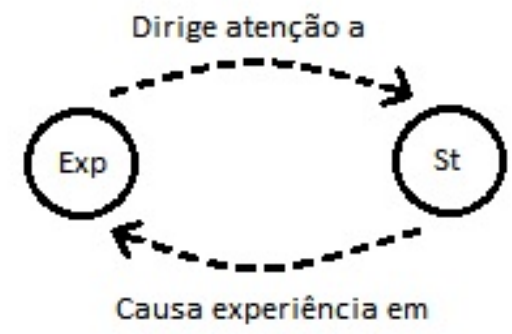

Figura 10: Evento experiencial bidirecional

Observe que a figura acima ilustra a conceitualização bidirecional de eventos experienciais da qual temos falado. As setas tracejadas indicam contato mental e sua direção. Alguns esclarecimentos são importantes neste momento a respeito da natureza dessa conceitualização e seu status.

A começar, essa é uma conceitualização que acreditamos ser fundamental e mais abstrata, mas que se constrói a partir de outras concepções, inclusive arquetípicas como o próprio arquétipo de experienciador como seu participante primário. Comentamos, anteriormente, que apesar de emoções diferentes, assim como sensações, poderem evocar domínios distintos abrangendo aspectos que possivelmente as diferenciam, como culturais, sociais, enciclopédicos, etc., poderia haver um domínio emotivo, ou mesmo experiencial (envolvendo sensações físicas e outros tipos de percepção), que abarcaria certas dimensões conceituais comuns.

Dessa forma, a conceitualização acima seria justamente uma dessas concepções comuns, isso não significa que é a única forma de conceitualizarmos eventos experienciais, mas que é saliente o suficiente (e pervasiva no sentido de abrangência) para que seja frequentemente evocada na codificação de eventos experienciais, ainda que como parte de conceitualizações mais complexas.

Inicialmente, a própria concepção arquétipa de experienciador dá origem à conceitualização mais abstrata acima, sendo uma relação gestáltica na medida em que o experienciador e sua experiência são apreendidos como um todo coerente, isto é, a existência de um experienciador pressupõe uma experiência, dessa forma, haverá concepções, aterradas em nossa própria experiência no mundo, que serão evocadas para que essa relação seja compreendida e codificada linguisticamente. 
Uma concepção fundamental que assim decorre envolve algumas noções arquetípicas que vimos, como a noção de inclusão (dentro) e fora, observe que embora essa relação seja metafórica na medida em que se relaciona, inclusive em mapeamentos mais elaborados, com o domínio mais concreto espacial (como observamos em diversas expressões), essa relação é experiencialmente aterrada no próprio domínio emotivo e físico já que sentimos experiências emocionais e físicas sem que necessariamente o externo (o ambiente, o outro) veja ou possa experienciar também.

Essa diferença e oposição do interno e do externo dá uma coerência relativamente ao experienciador e sua experiência, sendo esse o primeiro aspecto que figura na conceitualização ilustrada acima. Seu segundo aspecto é a própria percepção do externo, se da mesma forma há a percepção de que experiências ocorrem no interior em oposição ao exterior, há a percepção de que somos suscetíveis ao externo, isto é, os eventos que acontecem no externo a nós podem nos afetar de modo que ligamos experiências interiores a eventos externos. Assim, o fato de ocorrências externas entrarem em nosso campo de percepção, isto é, de dirigirmos nossa atenção a elas, faz com que emoções sejam causadas ou suscitadas.

Veja que o externo pode ser tanto entendido como o rótulo usado acima de estímulo (um evento, participante, etc.) quanto como o próprio evento experiencial, isto é, as emoções ou sensações, já que surgem em nosso campo experiencial interior, mas são concebidas como tendo causas, sejam elas identificáveis ou não. Esse é um ponto importante notado por Kövecses (2005), de que emoções e sensações são concebidas como tendo causas (externas, mas também internas).

É essa concepção abstrata bidirecional que está por trás da conceitualização comum ilustrada acima que acreditamos existir de forma bastante saliente na conceitualização de eventos experienciais nas línguas.

Observe que essa conceitualização abstrata é a base para mapeamentos metafóricos ainda mais elaborados, em que diferentes partes desse evento são perfiladas e mapeadas metaforicamente em relação a outros domínios, inclusive, mais concretos de nossa experiência, como eventos de dinâmica de forças (emoções e suas causas como forças que atingem o experienciador) e noções espaciais (como experienciadores tidos metaforicamente como locais e de onde surge a emoção) como temos discutido.

Como dissemos há pouco, o 'estímulo' é um rótulo que abarca não só participantes, mas também causas não agentivas, eventos reais ou imaginados, etc. Assim, quando é dito 'atenção dirigida ao estímulo', é enfatizado o fato de que algo 
acontece ou ocorre ao campo ou domínio de consciência ou perceptual do experienciador para que ele sinta uma emoção ou mesmo sensação física, ainda que esse estímulo ou causa não seja diretamente codificado linguisticamente, sendo, muitas vezes, dado contextualmente.

Dessa forma, a representação conceitual acima não corresponde ao número de argumentos de um evento experiencial, nem afirma a obrigatoriedade de codificação conjunta desses elementos, no máximo, seria possível dizer que, por se tratar justamente de um evento experiencial, a presença daquele que experiencia é obrigatória.

Como discutido na seção 5.3.1, nem sempre eventos emocionais ocorrem com um segundo participante como estímulo (embora seja uma opção natural), sendo os casos mais críticos os eventos de sensação física, em que não há como dirigir a sensação a outro participante. De fato, essa é apenas uma ramificação da conceitualização de eventos experienciais, pois, como concluímos na seção 5.3.1, esse é um aspecto de diferenciação que não parece acarretar aparentemente tratamentos distintos nas línguas, sendo que outros aspectos em comum entre esses eventos são salientados.

E a conceitualização bidirecional acima parece justamente delinear esses aspectos em comum, sem, no entanto, restringir. Tanto eventos emocionais, quanto de sensação física são conceitualizados bidirecionalmente na medida em que o 'estímulo' abarca a concepção complexa de algo estando no domínio de consciência do experienciador e que faz com que o experienciador tenha sua atenção direcionada.

Um indício dessa conceitualização é o fato de que eventos de sensação física, assim como emocionais podem aparecer em construções em que é perfilada a porção em que o evento é tido como causado externamente. Observe que em muitos casos, o estímulo ou causa per se não é codificado, apenas a emoção ou sensação física, por exemplo, 'me veio um sono/tristeza'. Nesses casos, como inclusive a análise vista de Kövecses (2005) aponta, há uma causa que induz alguém a ter uma emoção, e a emoção, por sua vez, causa esse alguém a produzir alguma resposta (como resistência ou perda de controle), assim, emoções e sensações são concebidas como tendo causas, sendo entendidas metonimicamente em termos de suas causas, i.e., emoções são efeitos de algo (e causas de uma resposta). Assim, haverá metáforas que focarão mais na emoção como uma força que causa uma resposta e outras que irão focar na causa da emoção como uma força dando origem à própria emoção.

Por essa perspectiva, nesses eventos, é enfatizada a emoção como algo incontrolável ocorrendo ao experienciador, isto é, a própria resposta emocional ou física 
(a perda de controle em uma dinâmica de forças) é salientada. Interessantemente, essa ênfase acontece via a concepção de que emoções e sensações físicas têm causas, mas que nem sempre são identificáveis ou mesmo que precisem ser identificadas no momento. De fato, é parte de nossa experiência no mundo que uma sensação física como dor ou sono (ou mesmo emocional, como tristeza ou raiva) têm uma razão ou causa de ocorrer (i.e., que somos suscetíveis ao externo), não significando, porém, que sempre é possível identificar ou mesmo necessário identificar essa causa.

E é justamente isso que acontece em eventos experienciais tidos como causados externamente, nem sempre se faz necessário identificar a causa que resulta na emoção ou sensação, mas sim o fato de que a emoção metaforicamente tida como causada externamente atinge o experienciador como uma força, de forma que ele normalmente não pode controlar.

Em diversos casos, inclusive, essa força pode ser interna, como no caso da metáfora da raiva como um liquído quente em um container, sendo uma força que atinge tal grau que exacerba o experienciador e sai fora do controle como em 'ele explodiu de raiva' (cf. Kövecses, 2005). Ou em casos de construções com verbos de 'emanação corporal' (cf. seção 5.8), em que a causa é interna, podendo esses eventos serem construídos como menos ou mais controláveis pelo experienciador.

Observe que, mesmo em casos de causa interna, como é o caso da ocorrência de muitas sensações físicas, as concepções de 'externo' e 'incontrolável' estão também presentes já que concebemos frequentemente o corpo como compartimentalizado, como composto por regiões delimitadas (cf. discussão na seção 5.3.1 sobre a codificação de emoções e sensações como ocorrendo em locais específicos do corpo). Decorre que sensações físicas (e potenciais causas) são comumente concebidas como ocorrendo nessas regiões delimitadas e afetando nosso ego consciente que é separado (outra região delimitada), normalmente de forma incontrolável e 'externa'.

Ademais, na figura 10 acima, a porção em que o experienciador dirige sua atenção indica que foi preciso que algo (seja o estímulo ou evento complexo) ocorresse em seu campo de consciência ou de atenção para que a emoção ou sensação pudesse surgir ou despertar.

Observe que é uma via de mão dupla, um evento experiencial não pode ser causado ou ocorrer ao experienciador sem que a atenção desse experienciador esteja focada em sua ocorrência. 
Interessantemente, o fato de haver nas línguas construções experienciais locativas ou marcadas com estruturas típicas da esfera circunstancial (e.g. com a cópula) ou ainda que marcam a emoção como estando metaforicamente próxima do experienciador, como vimos, indicam justamente esse aspecto da conceitualização bidirecional de eventos experienciais, em que é perfilada a porção em que a emoção ou sensação física está localizada no domínio de consciência do experienciador (ou que surge a partir dele como locus), havendo, em muitos casos, a opção de se marcar de forma mais perifrástica o estímulo, ou causa da emoção.

De forma similar à notada por Langacker (2009) no caso de eventos de posse, cada construção experiencial, ainda mais considerando sua diversidade e diferentes oposições internamente à língua, vai ter um importe conceitual distinto, podendo ocorrer atenuações e fortalecimentos de certos aspectos da conceitualização bidirecional notada acima.

Por exemplo, em muitos casos em que a experiência é tida como a surgir do experienciador, sendo-lhe normalmente atribuída maior proeminência, pode ocorrer um fortalecimento do seu papel iniciativo, como em certos casos de eventos experienciais médios. Em outros, como já notamos nos casos em que a construção tem uma base em que o evento era tido como causado externamente, o papel não volicional e afetado do experienciador é fortalecido e herdado na construção com o experienciador como foco primário.

Em construções mais 'espaciais', como locativas e dativas, é enfatizado não só o caráter diferencial desse tipo de evento em relação a um evento canônico, mas também há a conceitualização metafórica do espaço próximo ou interior do experienciador como seu domínio de experiência. Além do mais, contrário do que poderia ser esperado de uma marcação estática de experienciadores e eventos experienciais (através, por exemplo, da cópula), há a influência da esfera ativa, do ponto de vista egocêntrico a partir desse extremo, por meio de noções de interação e de movimento.

Em construções experienciais marcadas de forma mais canônica (como 'eu amo ele'), apesar de serem atenuados alguns aspectos presentes mais fortemente em outras construções como o não controle e a afetação por parte do experienciador, ainda assim, são eventos baixos em transitividade em que o experienciador é menos agentivo comparadamente a eventos físicos canônicos.

O mesmo acontece com o estímulo, em alguns casos seu papel causal é salientado (como no português 'eu senti raiva dele'), em que a experiência é construída 
como vindo a partir do estímulo, já em outros, é dada proeminência ao seu papel mais passivo ou neutro em que a emoção é dirigida a ele (como em 'eu senti amor por ele').

Dessa forma, não é acidental a mudança observada nas línguas em que o experienciador marcado não canonicamente adquire maior proeminência focal, sendo decorrente de um deslocamento natural em que diferentes porções dessa conceitualização estão sendo perfiladas.

Em casos de eventos experienciais causados externamente, por exemplo, a porção perfilada é aquela em que o estímulo (ou a própria emoção causada) age como uma força que afeta o experienciador:

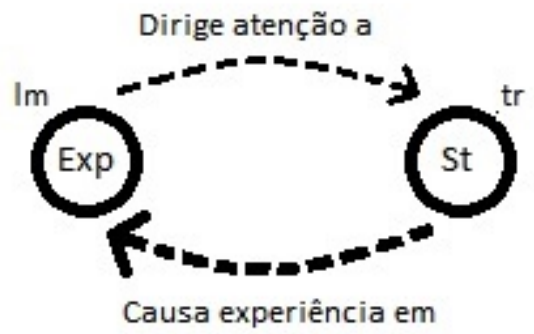

Figura 11: Evento experiencial bidirecional: evento causado externamente

Observe que a representação acima é esquemática e abstrai detalhes específicos de diferentes construções que a instanciam. Na ilustração acima, os dois participantes seriam perfilados, sendo a causa como trajetor e o experienciador como marco.

Se pensarmos nas construções discutidas do georgiano (capítulo 5 como um todo e a mudança ocorrida do georgiano antigo ao moderno), uma origem conceitual em que o estímulo nominativo (trajetor e atrator de uma parte importante de comportamentos sintáticos em georgiano antigo) causava a emoção no experienciador dativo de forma incontrolável torna-se uma hipótese plausível, ainda mais tendo em vista os dados que temos visto de outras línguas (cf. exemplos (231) a (235); (236) a (238)) e também do próprio georgiano (como as construções com a vogal pré-radical -e-).

De fato, a construção dativa em georgiano moderno herda muitas das características que temos comentado a partir de eventos que seriam originalmente concebidos como causados externamente. Dentre elas, a afetação e não volicionalidade do participante dativo. Dessa forma, uma explicação conceitual da mudança ocorrida 
em georgiano parece estar na escolha de diferentes perfis de um evento experiencial bidirecional, havendo um deslocamento da Figura 11, em que o evento era construído como causado externamente indo em direção ao alvo, o experienciador marcado com o dativo e locus da emoção, para a Figura 12 abaixo, em que o evento é construído de forma que o experienciador continua sendo o locus da emoção, mas como fonte de energia, i.e., de onde a emoção surge e é direcionada ao estímulo.

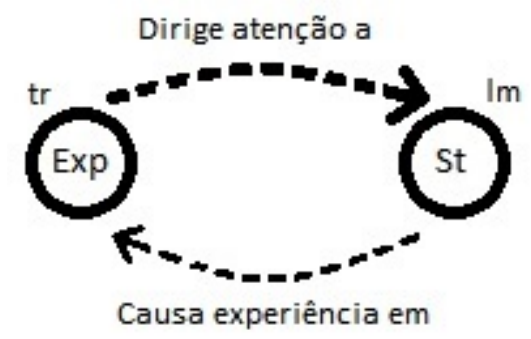

Figura 12: Evento experiencial bidirecional: evento a surgir do experienciador

Uma consequência desse deslocamento é a maior proeminência dada ao experienciador, escolhido como figura , i.e., foco primário ( $t r$ na Figura 12), e atração de privilégios sintáticos como concordância, no verbo, de terceria pessoa no georgiano.

Interessantemente, a construção dativa em georgiano, que tem como protótipo construções com verbos psicológicos e de sensação física (e também, em certa medida, de posse e modais, correlação, aliás, frequente nas línguas), consiste em um padrão suficientemente arraigado e convencionalizado na língua de modo que ele próprio é evocado como esquema (abstraído a partir de eventos de uso) para a sanção de outras expressões, havendo casos de extensão (cf. seção 2.2.5).

Lembrando, como discutido na seção 2.2.5, que extensões a partir de um protótipo (categorização por extensão) o instanciam parcialmente, o que explicaria a extensão do padrão dativo a verbos considerados prototipicamente não experienciais (como os verbos desiderativos, de julgamento e aqueles discutidos na seção 5.5), nesses casos, algumas características parecem se manter, como a afetação e a não volicionalidade do participante dativo.

A relação próxima entre posse e eventos experienciais foi discutida acima (e também quando vimos a análise de Maldonado (2002) sobre posse externa). Observe 
que ambos, possuidores e experienciadores, pressupõem uma esfera de controle ou de consciência (seu domínio), daí sua relação muito próxima, em que objetos, propriedades, emoções e sensações são localizadas relativamente a essa esfera experiencial (facilitando a marcação através de locativos, cópulas e verbos existenciais), e em que mudanças ocorridas nessa esfera ocasionam a afetação desses participantes (afetação essa fortalecida grandemente em eventos de posse externa).

Já no caso de verbos modais e evidencialidade, discutimos conexões conceituais importantes na seção 5.7 sobre evidenciais e na seção 5.3 .3 sobre modais. Modais são um caso interessante, pois são eventos de baixa transitividade por serem irrealis, normalmente apresentando projeções no futuro e possibilidades não concretizadas ou não confirmadas, seus participantes, portanto, tendo um menor grau de volicionalidade e controle sobre o evento. Dessa forma, uma marcação não canônica de modais é frequentemente atestada em construções impessoais e dativas nas línguas (cf. exemplos do russo na seção 5.3.3), em que o evento modal, como possibilidade e obrigação, é concebido como indo em direção ao domínio do experienciador ('é possível para mim', 'é necessário para mim'), havendo em muitos casos o deslocamento de proeminência que observamos no caso de verbos experienciais e de posse ('eu posso', 'eu devo'). Novamente, parece-nos que as noções de proximidade e contiguidade espacial também se aplicam, já que algo estando próximo ao domínio do experienciador faz com que seja possível, ou necessário, que ele faça ou experiencie. ${ }^{183}$

Disso, podemos argumentar que os grupos semânticos delineados na figura 1, apesar das diferenças de significado, possuem semelhanças de família de forma que compartilham certos atributos uns com os outros. Particularmente importante, são as noções de não volicionalidade e afetação que essas construções compartilham em menor ou maior grau como temos discutido.

Dessa forma, as construções com dativos vistas formam uma família de construções em georgiano, um rede de construções, sendo verbos experienciais (principalmente emocionais e físicos) membros mais centrais do esquema, seguidos de perto de verbos de posse e modais, enquanto outros (como verbos de julgamento e desiderativos) sendo membros mais periféricos. ${ }^{184}$

\footnotetext{
183 O domínio dos modais nas línguas é complexo e não nos aprofundaremos aqui dadas as limitações e objetivos da tese, sendo essa observação preliminarmente relativa à ocorrência em construções dativas e tendo como base o que discutimos ao longo do texto.

${ }^{184}$ Não citamos a construção de transferência como central, pois acreditamos que, no georgiano, em específico, a construção experiencial com dativos é uma forte especialização, formando um núcleo em
} 
si. De todo o modo, como discutimos neste capítulo, o dativo em verbos experienciais e em verbos de transferência estão fortemente conectados em termos de significado (codificando participantes ativos e sencientes e que fazem contato mental com outra entidade em seu domínio). 


\section{CONSIDERAÇÕES FINAIS}

Traçamos o objetivo de descrever as construções dativas experienciais em georgiano a partir de seu significado, chegando ao objetivo mais amplo de lançar luz sobre a forma como conceitualizamos eventos experienciais.

Assim sendo, argumentamos que a mudança observada em georgiano, em que o participante dativo adquire privilégios sintáticos como concordância no decorrer da história da língua, é reflexo de diferenças conceituais.

Com base nos dados recolhidos, do georgiano e outras línguas, observamos que eventos experienciais são conceitualizados de forma bidirecional, ou seja, para que o estímulo cause uma emoção no experienciador, é preciso que o experienciador dirija sua atenção ao estímulo, i.e., que o estímulo esteja no seu campo de consciência. Assim, não haveria uma direcionalidade única no fluxo de energia, o experienciador é tanto a fonte de energia, de onde ele dirige sua atenção ao estímulo, quanto o ponto final energético, na medida em que o estímulo lhe causa ou provoca dada emoção.

Decorre daí, e em contraste com agentes e pacientes prototípicos, que experienciadores e estímulos não seriam nem típicos iniciadores (fontes de energia), nem típicos pontos finais energéticos.

É essa concepção abstrata bidirecional (envolvendo concepções arquétipas discutidas extensamente) que argumentamos estar por trás da conceitualização comum que existiria de forma bastante saliente na conceitualização de eventos experienciais nas línguas e que também motivaria, por conseguinte, a codificação metafórica de experienciadores através de dativos e locativos.

Essa conceitualização abstrata seria a base para mapeamentos metafóricos ainda mais elaborados, em que diferentes partes do evento experiencial são perfiladas e mapeadas metaforicamente em relação a outros domínios mais concretos de nossa experiência, como eventos de dinâmica de forças (emoções e suas causas como forças que atingem o experienciador) e noções espaciais (como experienciadores tidos metaforicamente como locais ou containers, de onde surge a emoção ou onde a emoção é causada).

Dessa forma, a mudança observada em georgiano é reflexo de um deslocamento de perfil conceitual em que, de um evento concebido como causado externamente e que 
afeta o participante dativo, passou-se a perfilar a porção do evento em que o experienciador dirige sua atenção, sendo tido como fonte de energia e locus de onde a emoção surge e é dirigida ao estímulo nominativo.

Uma consequência, portanto, desse deslocamento é a maior proeminência dada ao experienciador, escolhido como foco primário, e a gradativa atração de privilégios sintáticos como concordância, além de uma herança conceitual do experienciador no dativo como afetado e menos volitivo.

Espera-se assim, e argumentada essa caracterização conceitual, que outros estudos tipológicos, sincrônicos e diacrônicos, possam vir a corroborar, acrescentar, melhorar ou modificar a análise aqui oferecida, na esperança de que possamos cada vez mais entender, por meio da diversidade fascinante das línguas, o domínio complexo que é o campo das emoções e experiências humanas. 


\section{REFERÊNCIAS BIBLIOGRÁFICAS}

AARTS, Bas. Syntactic Gradience: The Nature of Grammatical Indeterminacy. New York: Oxford University Press, 2007.

ACHARD, Michel. Representation of Cognitive Structures: Syntax and Semantics of French Sentential Complements. Berlin: Mouton de Gruyter, 1998.

ACHARD, M., DIRVEN, R., IBANEZ, F. J. R. de M., KRISTIANSEN, G. (eds.). Cognitive Linguistics Current Applications and Future Perspectives. Berlin/New York: Mouton de Gruyter, 2006.

AIKHENVALD, Alexandra. The Arawak language family. In R. M. W. Dixon; Alexandra Y. Aikhenvald (eds.). The Amazonian languages, 1999. pp. 65-106.

Dicionário Tariana-português. Bol. Mus. Par. Emílio Goeldi, 2002. A Grammar of Tariana. Cambridge: Cambridge University Press, 2003. Evidentiality. Oxford: Oxford University Press, 2004.

AIKHENVALD, Alexandra; DIXON, Robert \& ONISHI, Masayuki (eds.). NonCanonical Marking of Subjects and Objects. Amsterdam: John Benjamins, 2001.

AIKHENVALD, Alexandra, Y.; DIXON, R. M. W. Introduction: Linguistic Typology Setting the scene. In: AIKHENVALD, Alexandra, Y.; DIXON, R. M. W. (eds.). The Cambridge Handbook of Linguistic Typology. United Kingdom: Cambridge University Press, p. 1-36, 2017.

AMIRIDZE, N. Reflexivization strategies in Georgian. Ph. D.dissertation. Universiteit Utrecht, 2006.

ANAGNOSTOPOULOU, Elena. On experiencers. In: ALEXIADOU, Artemis; HORROCKS, Geoffrey; STAVROU, Melita (eds.). Studies in Greek syntax. Dordrecht: Kluwer, p. 67-93, 1999.

ANAGNOSTOPOULOU, Elena. Psych verbs. Handout from Athens reading group in linguistics, April 11, 2008.

ANDERSON, S. R. On representations in morphology. Case agreement and inversion in Georgian. Natural Language and Linguistic Theory, 2(2):157-218, 1984.

ANDERSON, Gregory \& GUREVICH, Olga. Toward a Typology of Version: Formal and Functional Perspectives, 2005.

ARAD, Maya. Psych-notes. UCL Working Papers in Linguistics 10. London: University College, 1998. 
What counts as a class? The case of psych verbs. In: MIT Working Papers in Linguistics 35. Cambridge, MA: MIT Press, p. 1-23, 1999.

ARONSON, H. I. Towards a semantic analysis of case and subject in Georgian. Lingua, 25:291-301, 1970.

. Georgian: a reading grammar. Columbus: Slavica, [1982] 1990.

On the status of version as a grammatical category in Georgian. Folia Slavica 5: p.66-80, 1982.

ARONSON, H I; KIZIRIA, D. Georgian language and culture: a continuing course. Slavica, 1999.

ASATIANI, Rusudan. nebelobis semant'ik'uri k'at'egoriis gamoxat'va kartulzmnebsi [The expression of volition in Georgian verbs]. In Z. Sarjveladze, editor, Works of the Chair of the Georgian Language of the Tbilisi State PedagogicalUniversity, volume 4, pages 25-36. Tbilisi State Pedagogical University Press, Tbilisi, 1998. (in Georgian).

BAKER, Mark C. Incorporation: A theory of grammatical function changing. Chicago: University of Chicago Press, 1988.

Thematic roles and syntactic structure. In: HAEGEMAN, Liliane (ed.). Elements of grammar: Handbook in generative syntax, p. 73-137, 1997.

BARĐDAL, Jóhanna. The Semantics of the Impersonal Construction in Icelandic, German and Faroese: Beyond Thematic Roles. In: Werner Abraham (ed.). Focus on Germanic Typology. Akademie Verlag, 2004. pp.105-137.

Productivity: Evidence from Case and Argument Structure in Acelandic. Amsterdam/Philadelphia: John Benjamins Publishing Company, 2008.

The rise of Dative Substitution in the history of Icelandic: A diachronic construction grammar account. Lingua 121, p. 60-79, 2011.

BARĐDAL, Jóhanna; SMITHERMAN, Tomas; BJARNADÓTTIRB, Valgerður; DANESIA, Serena; JENSETCD, Gard B.; MCGILLIVRAY, Barbara. Reconstructing constructional semantics: The dative subject construction in Old Norse-Icelandic, Latin, Ancient Greek, Old Russian and Old Lithuanian. Studies in Language 36/3, p. 511-547, 2012.

BECKER, Laura; GUZMÁN, Matías. Psych predicates from a cross linguistic perspective. $L B, M G N$, 9-11.06.2016, Olomouc, 2016.

BĘDKOWSKA-KOPCZYK, Agnieszka. Dispersed motion metaphors of emotion in Slovene: a cognitive grammatical analysis of the prefix raz- in verbs of emotional experience. In: Ljiljana Šarić (ed.) Space in South Slavic, Oslo Studies in Language 5(1), p. 91-113, 2013. 
- Verbs of emotion with se in Slovene: between middle and reflexive semantics. A cognitive Analysis. Cognitive Studies, 14, p. 203-218, 2014.

van BELLE, W. van LANGENDONCK, W. The Dative, Vol 1. Amsterdam, Philadelphia: John Benjamins, 1996.

BELLETTI, Adriana \& RIZZI, Luigi. Psych-verbs and theta theory. Natural Language and Linguistic Theory 6, p. 291-352, 1988.

BERG-OLSEN, S. The Latvian dative and genitive: A Cognitive Grammar account. Dissertation. Department of East European and Oriental Studies. Faculty of Arts. University of Oslo, 2004.

BHASKARARAO, Peri \& SUBBARAO, K. V. (eds.). Non-nominative Subjects, vol. I. Amsterdam/Philadelphia: John Benjamins Publishing Company, 2004a.

. Non-nominative Subjects, vol. II. Amsterdam/Philadelphia: John Benjamins Publishing Company, 2004b.

BHATIA, Tej. Punjabi: A cognitive-descriptive grammar. London \& New York: Routledge, 1993.

BIALY, Adam. Polish Psychological Verbs at the Lexicon-Syntax Interface in Crosslinguistic Perspective. Frankfurt am Main: Peter Lang, 2005.

BLAKE, Barry J. Case. Cambridge: Cambridge University Press, 1994.

BLUME, K. A contrastive analysis of interaction verbs with dative complements. Linguistics 36(2), p.253-280, 1998.

BOEDER, W. Evidentiality in Georgian. In: Bo Utas and Lars Johanson (ed.). Evidentials in Turkic, Iranian and Neighboring Languages. Berlin: Mouton de Gruyter, 2000 .

BOSSONG, Georg. Le marquage de l'expérient dans les langues d'Europe. In: Feuillet, Jack (ed.). Actance et valence dans les langues de l'Europe. Berlin: Mouton de Gruyter, 1998. p.259-294.

BOUCHARD, Denis. The semantics of syntax: A minimalist approach to grammar. Chicago: University of Chicago Press, 1995.

BROADWELL, George Aaron. A Choctaw Reference Grammar. Lincoln, NE: University of Nebraska Press, 2006.

BUTT, Miriam. The Dative-Ergative Connection. In: BONAMI, O. \& HOFHERR, P. (eds.). Empirical Issues in Syntax and Semantics 6, p. 69-92, 2006.

CAMPBELL, Liam. Georgian Language Comprehensive. First Edition, s/d.

CAMPBELL, Liam. Georgian Verbs Comprehensive. First Edition, s/d (b). 
CAMPBELL, L. \& HARRIS, A. C. Historical Syntax in Cross-Linguistic Perspective. Cambridge: Cambridge University Press, 1995.

CANÇADO, Márcia \& FRANCHI, Carlos. Exceptional binding with Psych Verbs? Linguistic Inquiry 30 1: p. 133-143, 1999.

CANÇADO, M. Verbos psicológicos: análise descritiva dos dados do português brasileiro. Revista de Estudos da Linguagem, v. 4, n.1, p. 89-114, 1996.

Uma aplicação da teoria generalizada dos papéis temáticos: verbos psicológicos. Revista do GEL, n. especial, 93, 125, 2002.

Verbos psicológicos: uma classe relevante gramaticalmente? Veredas Atemática, vol. 16, n.2, p. 1-18, 2012.

CARNEIRO, Beatriz P. Uma investigação sobre mapeamento de argumentos $e$ aquisição de verbos psicológicos. Dissertação de Mestrado. Brasília, 2011.

CARVALHO, Gabriele C. O frame dos verbos psicológicos: relações de herança entre as construções com verbos plenos e verbos leves. Tese de doutorado. UFMG, Belo Horizonte, 2015.

CATE, B.D. \& ZEEVAT, H.W. Logic, Language, and Computation: 6th International Tbilisi Symposium on Logic, Language, and Computation, TbiLLC 2005 Batumi, Georgia, September 12-16, 2005. Revised Selected Papers. Berlin, Heidelberg: Springer Berlin Heidelberg, 2007.

CHAFE, William. Discourse, consciousness and time: The flow and displacement of conscious experience in speaking and writing. Chicago: University of Chicago Press, 1994.

CHERCHI, Marcello. Modern Georgian morphosyntax. A grammaticocategorialhierarchy-based analysis with special reference to indirect verbs and passives of state. Wiesbaden: Harrassowitz Verlag, 1997.

CHIKOIDZE, G. The Marking of Verb-Actant Relations in Georgian. International Tbilisi Symposium on Logic, Language, and Computation 2005: Logic, Language, and Computation, pp 85-95, 2005.

COMRIE, Bernard; van den BERG, Helma. Experiencer constructions in Daghestanian languages. In: BORNKESSEL, Ina; SCHLESEWSKY, Matthias; COMRIE, Bernard; FRIEDERICI, Angela D. (eds.). Semantic role universals and argument linking: theoretical, typological and psycholinguistics perspectives. Berlin: de Gruyter, p. 127$154,2006$.

COMRIE, Bernard; KHALILOVA, Zaira. Experiencer constructions in Tsezic languages. Bernard Comrie and Zaira Khalilova. Workshop on Non-Canonically CaseMarked Subjects within and across languages and language families, June 4th, 2012, University of Iceland, Reykjavík, 2012. 
COMRIE, Bernard; POLINSKY, Maria. The Great Daghestanian Case Hoax. In: SIEWIERSKA, A; SONG, J. J. (ed.). Case, Typology and Grammar. Amsterdam \& Philadelphia: John Benjamins Publishing Group, 1998.

CORREA, Paulo, A. Construções de mudança de estado e divergências na aquisição de espanhol L2. Linguística, Rio de Janeiro, v.3, n.2, p. 295-311, dezembro, 2007.

CROFT, William. Surface subject choice of mental verbs. Paper Presented at the Annual Meeting of the Linguistics Society of America. New York, 1986

Syntactic Categories and Grammatical Relations: The Cognitive Organization of Information. Chicago: University of Chicago Press, 1991.

. Radical Construction Grammar: Syntactic Theory in Typological Perspective. Oxford: Oxford University Press, 2001.

Case marking and the semantics of mental verbs. In: Pustejovsky, J. (ed.). Semantics and the Lexicon. Dordrecht: Kluwer, p. 55-72, 1993.

Voice: Beyond control and affectedness. In: FOX, B. \& HOPPER, P. J. (eds.). Voice: Form and Function. Amsterdam: John Benjamins, p. 89-117, 1994.

Verbs: Aspect and Causal structure. Oxford: Oxford University Press, 2012.

. Typology and the future of cognitive linguistics. Cognitive Linguistics; 27(4), p. 587-602, 2016.

CROFT, William \& CRUSE, Alan. Cognitive Linguistics. Cambridge Textbooks in Linguistics. Cambridge: Cambridge University Press, 2004.

CUNHA, C. D.; DOGLIANI, E. . Verbos Psicológicos: a relação entre a perspectiva do evento, a realização morfológica e os gêneros textuais.. In: XII Congresso Nacional de Linguistica e Filologia., 2008, Rio de Janeiro. Revista do IEEE América Latina. RJ: UERJ, 2008. v. 12. p. 138-150, 2008.

CUERVO, María Cristina. Datives at Large. Doctoral Dissertation, MIT, 2003.

Some Dative Subjects Are Born, Some Are Made. In: Selected Proceedings of the 12th Hispanic Linguistics Symposium. BORGONOVO et al. Somerville, MA: Cascadilla Proceedings Project, p. 26-37, 2010.

CUYCKENS, H. \& GEERAERTS, D. (eds.). The Oxford Handbook of Cognitive Linguistics. New York: Oxford University Press, 2007.

DABROWSKA, Ewa. Cognitive Semantics and the Polish Dative. New York \& Berlin: Mouton de Gruyter, 1997. 
491, 2016.

Cognitive linguistics' seven deadly sins. Cognitive Linguistics; 27(4), p. 479-

DAHL, Eystein; FEDRIANI, Chiara. The Argument Structure of Experience: Experiential Constructions in Early Vedic, Homeric Greek and Old Latin. TPhS, 110/3, p. 342-362, 2012.

DIDESIDERO, Linda. 1999. Psych Verbs: Acquisition, Lexical Semantics, and Event Structure. Ph.D. Thesis, Northwestern University, Evanston, IL, 1999.

DINGEMANSE, M. The body in Yorubá: A linguistic study. Universiteit Leiden, 2006.

DIVJAK, D. \& CALDWELL-HARRIS, C. Frequency and entrenchment. In: DABROWSKA, Ewa \& DIVJAK, D. Handbook of Cognitive Linguistics. Berlin: De Gruyter, p. 53-75, 2015.

DIVJAK, Dagmar; LEVSHINA, Natalia; KLAVAN, Jane. Cognitive Linguistics: Looking back, looking forward. Cognitive Linguistics; 27(4), p. 447-463, 2016

DIXON, R. M. W. Ergativity. Cambridge: Cambridge University Press.1994.

DIXON, R. M. W. \& AIKHENVALD, A. Changing Valency: Case studies in transitivity.Cambridge University Press, 2000.

DONOHUE, M. Split Transitivity and Saweru. Oceanic Linguistics 40, p.321-336, 2001.

Tipology and Linguistic Areas. Oceanic Linguistics 43, p.214-232, 2004.

Semantic alignment systems: what's what, and what's not. In M. Donohue and S. Wichmann (eds.). The Typology of Semantic Alignment. Oxford: Oxford University Press, 2008. p.24-75.

DOWTY, David R. Thematic Proto-roles and Argument Selection. Language 67 3: 547-619, 1991.

ELLIS, Nick C. \& ROBINSON, Peter. The Handbook of Cognitive Linguistics and Second Language Acquisition. New York/London: Routledge, 2008.

ELVIRA, Javier. Constructions of uncontrolled state or event. The increase in productivity ofa new argument structure in Old Spanish. Constructions and Frames. 3.2, p. 184-207, 2011.

ENGELBERG, Stefan. The argument structure of psych-verbs: A quantitative corpus study on cognitive entrenchment. In: BOAS, Hans \& ZIEM, Alexander Ziem (eds.). Constructional approaches to argument structure in German. Boston, Berlin: De Gruyter Mouton, (no prelo), 2014.

EVANS, Vyvyan. A Glossary of Cognitive Linguistics. Edinburgh: Edinburgh University Press, and Salt Lake City: University of Utah Press, 2007. 
EVANS, Vyvyan and GREEN, Melanie. Cognitive Linguistics: An Introduction. Mawhaw,N.J.: Erlbaum, 2006.

EVANS, Vyvyan, BERGEN, Benjamin K. and ZINKEN, Jörg (eds.). The Cognitive Linguistics Reader. London: Equinox, 2006.

EVANS, N \& WILKINS, D. The knowing ear: an Australian test of universal claims about the semantic structure of sensory verbs and their extension into the domain of cognition. Allgemeine Sprachwissenschaft, Institut für Linguistik, Universität zu Köln, 1998.

EVERAERT, Martin; MUSGRAVE, Simon; DIMITRIADIS, Alexis (eds.). The use of databases in cross linguistic studies. Berlin: Mouton de Gruyter, 2009.

FAUCONNIER, Gilles. Mental spaces: Aspects of meaning construction in natural language. Cambridge, MA: MIT Press, 1985.

FEDRIANI, Chiara. Experiential Constructions in Latin. Leiden/Boston: Brill, 2014.

FERRANDO, I. N. The Metaphorical use of on. Journal of English Studies I (1999), p.145-164, 1999.

FILLMORE, C. J. Frame semantics. In Linguistics in the Morning Calm. Selected Papers from SICOL-1981, The Linguistic Society of Korea (ed.), 111-137. Seoul: Hanshin, 1982.

FLOYD, Simeon, NORCLIFFE, E, SAN ROQUE, L. Egophoricity. Amsterdam: John Benjamins, 2018.

FORKER, Diana. Evidentiality in the Nakh-Daghestanian languages. In: Aikhenvald, A. (ed.). The Oxford Handbook of evidentiality. Oxford: OUP, 2018. p.490-509.

FOX, Barbara \& HOPPER, Paul.Voice: Form and Function. Amsterdam/Philadelphia: John Benjamins Publishing Company, 1994.

FRANCO, Jon. Towards a typology of psych verbs: Evidence from Spanish. In: MITWPL 12: Proceedings of the 2nd Meeting of SCIL, edited by Thomas Green and Sigal Uziel, 46-62. Cambridge, MA: MIT Press, 1990.

FRIEDMAN, V. Proverbial Evidentiality: On the gnomic uses of the category of status in languages of the Balkans and the Caucasus. Mediterranean Language Review, Vol. 11, 1999, p.135-155, 1999.

Evidentiality in the Balkans with special attention to Macedonian and Albanian. In A. Y. Aikhenvald, R. M. W. Dixon, eds., Studies in Evidentiality. Amsterdam, Philadelphia, 2003. p.189-218.

GAIR, James W. Studies in south Asian linguistics: Sinhala and other south Asian languages. Oxford University Press, USA, 1990. 
GANENKOV, Dimitry. Experiencer coding in Nakh-Daghestanian. In: KULIKOV, Leonid; MALCHUKOV, Andrej; DE SWART, Peter (eds.), Case, valency and transitivity (Studies in Language Companion Series 77). Amsterdam: John Benjamins Publishing Company, p. 179-202, 2006.

GÄUMANN, M. Topadze. The Expression of Evidentiality between Lexicon and Grammar. A Case Study from Georgian. Linguistic Discovery, Dartmouth College, Vol. 9, Issue 2, 2011.

GEERAERTS, Dirk (ed.). Cognitive Linguistics: Basic Readings. Cognitive Linguistics Research 34. Berlin: Mouton de Gruyter, 2006.

GEERAERTS, Dirk. Prospects for the past: Perspectives for cognitive diachronic semantics. In: WINTERS, Margaret E.; TISSARI, Heli; ALLAN, Kathryn (eds.). Historical Cognitive Linguistics. Berlin: De Gruyter Mouton, p. 333-356, 2010.

GERRITSEN, N. Russian Reflexive Verbs-In search of unity and diversity. Studies in Slavic and general linguistics. Vol.15. Amsterdam: Rodopi. 1990.

GILLES, F. Mental Spaces: Aspects of Meaning Construction in Natural Language. Cambridge: Cambridge University Press, 1994.

GILQUIN, Gaëtanelle. Corpus, cognition and causative constructions. Amsterdam/Philadelphia: John Benjamins Publishing Company, 2010.

GIVÓN, Talmy. The grammar of referential coherence as mental processing instructions. Linguistics 30, p. 5-55, 1992.

Syntax: An Introduction, vol. 1, 2nd ed. Amsterdam/Philadelphia: John Benjamins Publishing Company, 2001a.

Syntax: An Introduction, vol. 2, 2nd ed. Amsterdam/Philadelphia: John Benjamins Publishing Company, 2001b.

GODDARD, Cliff (ed.). Cross-linguistic Semantics. Amsterdam/Philadelphia: John Benjamins Publishing Company, 2008.

GOLDBERG, Adele. Constructions: A Construction Grammar Approach to Argument Structure. Chicago: Chicago University Press, 1995.

GOLDBERG, Adele (ed.). Conceptual Structure, Discourse, and Language. Stanford, CA: CSLI Publications, 1996.

GOLDBERG, Adele. 'Construction grammar', in E. K. Brown and J. E. Miller (eds), Concise Encyclopedia of Syntactic Theories. New York: Elsevier Science, 1997.

GRADY, Joseph. Metaphor. In: CUYCKENS, H. \& GEERAERTS, D. (eds.). The Oxford Handbook of Cognitive Linguistics. New York: Oxford University Press, 2007. 
GRAFMILLER, Jason. The semantics of syntactic choice. An analysis of English emotion verbs. Doctoral dissertation, Stanford University, 2013.

GRIMSHAW, Jane. Argument structure. Cambridge, MA: MIT Press, 1990.

GUREVICH, Olga I. Constructional Morphology: The Georgian Version. Ph. D. dissertation. University Of California. Berkeley, 2006.

HAAS, M. The classification of the Muskogean Languages. In: SPIER et al (ed.). Language, Culture, and Personality: Essays in memory of Edward Sapir. Menasha, Wis.: Banta Publishing Company, 1941. p.41-56.

HAMPE, Beate (ed.) From Perception to Meaning: Image Schemas in Cognitive Linguistics. Berlin and New York: Mouton de Gruyter, 2005.

HANSEN, B. The syntax of modal polyfunctionality revisited. In: Leiss, E; Abraham, W. (ed.). Modes of Modality. Modality, Typology, and Universal Grammar. Amsterdam: John Benjamins, 2014. pp.89-126

HARDY, H. \& SCANCARELLI (ed.). Native Languages of the Southwestern United States. Lincoln: University of Nebraska Press, 2005.

HARGREAVES, D. "Am I blue?": Privileged access constraints in Kathmandu Newar. In: FLOYD, Simeon, NORCLIFFE, E, SAN ROQUE, L. Egophoricity. Amsterdam: John Benjamins, 2018.

HARRIS, Alice C. Georgian syntax: a study in relational grammar. New York: Cambridge University Press, 1981.

Diachronic syntax: the Kartvelian case (Syntax and syntax 18). New York: Academic Press, 1985.

History in Support of Synchrony. Proceedings of the 30th Annual Meeting of the Berkeley Linguistic Society, 2004.

HARTSHORNE, Joshua K.; O'DONNELL, Timothy J.; SUDO, Yasutada; URUWASHI, Miki; SNEDEKER, Jesse; Linking Meaning to Language: Verbs of Psychological State and the Linking Problem. CogSci, 2010.

HASPELMATH, Martin. A Grammar of Lezgian. Berlin: Mouton de Gruyter, 1993.

External Possession in a European Areal Perspective. In: Doris Payne and Immanuel Barshi (ed.). External Possession. Amsterdam: John Benjamins, 1999. p.109-135.

Non-canonical marking of core arguments in European languages. In: AIKHENVALD, A.; DIXON, R. M. W.; ONISHI, M. (eds.). Non-canonical Marking of Subjects and Objects. Amsterdam: Benjamins, p. 53-83, 2001. 
Explaining the Ditransitive Person-Role Constraint: a usage-based account. Constructions 2/2004, 49 pp. University of Düsseldorf, 2004.

HERMON, Gabriella. Non-canonically marked A/S in Imbabura Quechua. In Aikhenvald, A. Y. and Dixon, R.M.W. and Onishi, M. (eds.). Non-canonical Marking of Subjects and Objects. Amsterdam \& Philadelphia: John Benjamins, 2001.

HEWITT, George. Review article. Revue des études géorgiennes et caucasiennes 3: 173-213. 1987

Georgian: A Structural Reference Grammar. Amsterdam/Philadelphia: John Benjamins Publishing Company, 1995.

Georgian: A learner's Grammar. London: Routledge, 1996.

HILLERY, Patrick J., The Georgian Language: An outline grammatical summary, available at www.armazi.com. Consultado em 2009.

HOCK, Hans Heinrich \& BASHIR, Elena (eds). The languages and linguistics of South Asia: a comprehensive guide. Berlin: Mouton de Gruyter, 2016.

HOLE, Daniel. Extra argumentality - affectees, landmarks, and voice. Linguistics 442, p. 383-424, 2006.

HOLISKY, Dee Ann: Aspect and Georgian medial verbs. Delmar, NY: Caravan Press, 1981. 274. 1987.

The case of the intransitive subject in Tsova-Tush (Batsbi). Lingua 71: 245-

HOLVOET, A. Modals in Baltic. In: HANSEN, B \& de HANN (ed.). Modals in the Languages of Europe. Berlin: Mouton de Gruyter, 2009. p.199-105.

HOLVOET \& NAU, N. (ed.). Grammatical relations and their non-canonical encoding in Baltic. Amsterdam, Philadelphia: John Benjamins, 2014.

HOPPER, Paul \& THOMPSON, Sandra. Transitivity in grammar and discourse. Language 56: 251-99, 1980.

IWATA, Seizi. The distinctive character of psych-verbs as causatives. Linguistic Analysis 25: p. 95-120, 1995.

JANDA, Laura. A Geography of Case Semantics: The Czech Dative and the Russian Instrumental. Berlin: Mouton de Gruyter, 1993.

Quantitative methods in cognitive linguistics: An Introduction. In: JANDA, Laura A. (ed.). Cognitive linguistics: The quantitative turn. The Essential Reader. Berlin: De Gruyter Mouton, p. 1-9, 2013. 
JANDA, L \& DIVJAK, D. The role of non-canonical subjects in the overall grammar of a language: A case study of Russian. In Marja-Liisa Helasvuo and Tuomas Huumo (eds.), Subjects in constructions: Canonical and non-canonical. Amsterdam \& Philadelphia: John Benjamins, 2015. p.293-317

JANSSEN, Theo \& REDEKER, Gisela(eds.). Cognitive Linguistics: Foundations, Scope, and Methodology. Cognitive Linguistics Research 15. Berlin: Mouton de Gruyter, 1999.

JAYASEELAN, K. A. The possessor-experiencer dative in Malayalam. In: BHASKARARAO, P. \& SUBBARAO, K.V. (eds.). Non-nominative Subjects, Volume 1. The Netherlands: John Benjamins Publishing Company, p.227-244, 2004.

The Serial Verb Construction in Malayalam. In: DAYAL, V. \& MAHAJAN, A. (eds.). Clause Structure in South Asian Languages. The Netherlands: Kluwer Academic Publishers, p. 152-198, 2004b.

JOHNSON, Mark. The body in the mind: The bodily basis of meaning, imagination, and reason. Chicago: University of Chicago Press, 1987.

JORGE, Paula, B. O clítico se no português brasileiro. Dissertação de Mestrado Universidade de São Paulo, São Paulo, 2016.

JUNG, H. Innovations in the rise of the dative-infinitive modal sentence in Russian. Zeitschriftfür Slawistik 55(4): p.377-99, 2010.

KACHRU et al. The notion of 'subject': a note on Hindi-Urdu, Kashmiri and Panjabi. In: VERMA, M.K. (ed.). The notion subject in South Asian Languages. University of Wisconsin, Center for South Asian Studies, Madison, 1976. p.79-108.

KEENAN, E. Towards a universal definition of subject. LI, C. (ed.). Subject and Topic. Academic Press, 1976. p.303-333

KEMMER, Suzanne. The Middle Voice. Typological Studies in Language 23. Amsterdam: John Benjamins, 1993.

KIMBALL, Geoffrey. Koasati Grammar. Lincoln, Nebraska: University of Nebraska Press, 1991.

KLAIMAN, M. H. Grammatical Voice (Cambridge Studies in Linguistics 59). Cambridge: Cambridge University Press, 1991.

KLEIN, Katarina \& KUTSCHER, Silvia. Psych-verbs and lexical economy. Arbeiten des Sonderforschungsbereichs 282 "Theorie des Lexikons" 122: p. 1-41, 2002.

KLIMEK, Dorota \& ROZWADOWSKA, Bozena. From Psych Adjectives to Psych Verbs. Poznan Studies in Contemporary Linguistics 39: p. 59-72. 2004.

KÖVECSES, Zoltán. Emotion concepts. New York: Springer Verlag, 1990. 
Anger: Its language, conceptualization, and physiology in the light of crosscultural evidence. In: TAYLOR, John R. \& MACLAURY, Robert E. (eds.). Language and the cognitive construal of the world. Berlin: Mouton de Gruyter, p. 181-196, 1995.

. Metaphor: A practical introduction. Oxford: Oxford University Press, 2002.

. Metaphor and emotion. 2005. Consultado em: https://www.researchgate.net/ publication/299392688

Metaphor in culture: Universality and Culture. Cambridge: Cambridge University Press, $2005 b$.

The Metaphor-Metonymy Relationship: Correlation Metaphors Are Based on Metonymy. Metaphor and Symbol, 28:2, p.75-88, 2013.

KUNO, Susumu \& KABURAKI, Etsuko. Empathy and Syntax. Linguistic Inquiry Volume 8 Number 4, MIT Pres, p. 627-672, 1977.

KUTSCHER, Silvia. Kausalität und Argumentrealisierung: Zur Konstruktionsvarianz bei Psychverben in europäischen Sprachen. Linguistische Arbeiten 528. Tübingen: Niemeyer, 2009.

Emotionsverben im Estnischen: Konstruktionsvarianz und Kausalstruktur. Finno-Ugrische Forschungen 61(1-3), p. 110-134, 2012.

LAKOFF, George \& JOHNSON, Mark. Metaphors we live by. Chicago: University of Chicago Press, 1980.

Philosophy in the flesh: The embodied mind and its challenge to Western thought. New York: Basic Books, 1999.

LAKOFF, George. Women, fire, and dangerous things: What categories reveal about the mind. Chicago: University of Chicago Press, 1987.

The Contemporary Theory of Metaphor. ORTONY, Andrew (ed.) Metaphor and Thought (2nd edition), Cambridge University Press, 1992.

LAMBERT, Silke. Beyond Recipients: Towards a typology of dative uses. Doctoral dissertation, University at Buffalo, 2010.

LANDAU, Idan. Psych adjectives and sematic selection. In: BIRD, Sonya; CARNIE, Andrew, HAUGEN, Jason D.; NORQUEST, Peter (eds.). Proceedings of the 18th West Coast Conference on Formal Linguistics. Somerville, MA: Cascadilla Press, p. 285298, 1999.

A typology of psych passives. In: HIROTANI, M. (ed.). Proceedings of the 32nd conference of the North Eastern Linguistic Society. University of Massachusetts, Amherst: GLSA Publications, p. 271-286, 2002.

The locative syntax of Experiencers. Cambridge, MA: MIT Press, 2010. 
LANGACKER, Ronald. An Introduction to Cognitive Grammar. Cognitive Science 10, p, 1-40, 1986.

W. Foundations of Cognitive Grammar, vol. 1: Theoretical Prerequisites. Stanford: Stanford University Press, 1987.

Foundations of Cognitive Grammar, vol. 2: Descriptive Application. Stanford: Stanford University Press, 1991.

Universals of Construal. Proceedings of the Nineteenth Annual Meeting of the Berkeley Linguistics, p.447-463, 1993.

Raising and transparency. Language, Vol. 71, No. 1, p.1-62, 1995.

. Grammar and Conceptualization. Cognitive Linguistics Research 14. Berlin: Mouton de Gruyter, 1999.

Concept, Image, and Symbol: The Cognitive Basis of Grammar. 2nd ed. Cognitive Linguistics Research 1. Berlin: Mouton de Gruyter, [1991] 2002.

LANGACKER, Ronald. Strategies of Clausal Possession. International Journal of English Studies, vol. 3 (2), p.1-24, 2003.

Press, 2008.

Cognitive Grammar: A Basic Introduction. New York: Oxford University

Investigations in Cognitive Grammar. Cognitive Linguistics Research 42. Berlin: Mouton de Gruyter, 2009.

Cognitive (construction) grammar. Cognitive Linguistics, 20(1), 167-176. doi:10.1515/COGL.2009.010, 2009b.

. Reflections on the Functional Characterization of Spatial Prepositions. Corela, HS-7, 2010, mis en ligne le 31 mai 2010, consulté le 01 mai 2019. URL:http://journals.openedition.org/corela/999.

. Working towards a synthesis. Cognitive Linguistics; 27(4), p. 465-477, 2016

LARSON, Richard. On the double subject construction. Linguistic Inquiry 19, p. 335392, 1988.

632, 1990.

Double objects revisited: a reply to Jackendoff. Linguistic Inquiry 21, p. 589-

LASCARATOU, Chryssoula. The Language of Pain: Expression or description?. Amsterdam \& Philadelphia: John Benjamins Publishing Company, 2007.

LEE, David. Cognitive Linguistics: An Introduction. Melbourne: Oxford University Press, 2001. 
LEISS, Elisabeth \& ABRAHAM, Werner (eds). Modes of Modality. Modality, Typology, and Universal Grammar. Amsterdam, Philadelphia: John Benjamins, 2014.

LEVIN, B. \& GRAFMILLER, J. Do you always fear what frightens you? In: KING, T. H. \& PAIVA, V. d. (eds.). From Quirky Case to Representing Space: Papers in Honor of Annie Zaenen. CSLI Publications, p. 21-33, 2013.

LICHTENBERK, F. Reciprocals and related meanings in To'aba'ita. In: NEDJALKOV, V. P. (Ed.). Reciprocal constructions. 5 volumes. Amsterdam/Philadelphia: John Benjamins Publishing Company, 2007, p. 1547-1571.

LOMASHVILI, Leila. Complex predicates: The syntax-morphology interface. Amsterdam/Philadelphia: John Benjamins Publishing Company, 2011.

LOKMANE, I \& KALNACHA, A. Modals Semantics and morphosyntax of the Latvian debitive. In: In: Leiss, E; Abraham, W. (ed.). Modes of Modality. Modality, Typology, and Universal Grammar. Amsterdam: John Benjamins, 2014.

LUODONPÄÄ-MANNI, Milla; PENTTILÄ, Esa; VIIMARANTA, Johanna (eds.). Empirical Approaches to Cognitive Linguistics: Analysing real-life data. Cambridge Scholars Publishing, 2017.

LUODONPÄ̈̈-MANNI, Milla; PENTTILÄ, Esa; VIIMARANTA. Introduction. In: LUODONPÄ̈̈-MANNI, Milla; PENTTILÄ, Esa; VIIMARANTA, Johanna (eds.). Empirical Approaches to Cognitive Linguistics: Analysing real-life data. Cambridge Scholars Publishing, p. 1-24, 2017.

LURAGHI, Silvia. Experiencer predicates in Hittite. In: KIM, Ronald; OETTINGER, Norbert; RIEKEN, Elisabeth; WEISS, Michael. Ex anatolia Lux: Anatolian and Indoeuropean studies in honor of H. Craig Melchert on the occasion of his sixty-fifth birthday. New York: Beech Stave Press, 2010.

MACLAURY, R. E. \& TAYLOR, J. R. (eds.). Language and the Cognitive Construal of the World. Trends in Linguistics: Studies and Monographs 82. Berlin/New York: Mouton de Gruyter, 1995.

MALCHUKOV, Andrej L. Case pattern splits, verb types and construction competition. In: Mengistu Amberber and Helen de Hoop (ed.). Competition and variation in natural languages: the case for case. Amsterdam: Elsevier, 2005. p.73-117.

Split intransitives, experiencer objects, and 'transimpersonal' constructions: (Re-)establishing the connections. In: M. Donohue \& S. Wichmann (eds). The Typology of Semantic Alignment. Oxford: OUP., 2008. p.76-100

MALCHUKOV, Andrej; SIEWIERSKA, Anna. Impersonal constructions: A cross linguistic perspective. Amsterdam/Philadelphia: John Benjamins Publishing Company, 2011. 
MALDONADO, Ricardo. Objective and subjective datives. Cognitive Linguistics 13/1, p. 1-65, 2002.

A media voz: problemas conceptuales del clítico SE em español. Mexico: Instituto de Investigaciones Filologicas, UNAM, 2002b.

Middle as a basic voice system. In Lilian Guerrero, Sergio Ibáñez \& Valeria Belloro (eds.), Studies in role and reference grammar. México: Instituto de Investigaciones Filológicas, UNAM, 2009.

MANNEY, Linda, J. Middle voice in modern greek: Meaning and function of an inflectional category. Amsterdam/Philadelphia: John Benjamins Publishing Group, 2000.

MARÍN, Rafael \& MCNALLY, Louise.. Inchoativity, change of state, and telicity: Evidence from Spanish reflexive psychological verbs. Natural Language and Linguistic Theory 29 2: 467-502, 2011

MARÍN, Rafael. Stativity and agentivity in Spanish psychological verbs. Workshop on the Syntax and Semantics of Experiencers. Berlin, June 20th, 2014.

MCGINNIS, Martha. Case and Locality in L-Syntax: Evidence from Georgian MITWPL 32: The UPenn/MIT Roundtable on Argument Structure and Aspect, ed. Heidi Harley, 1997.

MCQUILLAN, Peter. Modals in Irish. In: Hansen \& de Hann (ed.). Modals in the Languages of Europe. Berlin: Mouton de Gruyter, 2009. p.71-105.

MEDOVÁ, L. Reflexive Clitics in the Slavic and Romance Languages. Ph.D. dissertation. Princeton Universtiy, 2009.

MELIKISHVILI, Irine. Georgian as an Active/Ergative Split Language. Bulletin of the Georgian National Academy of Sciences, vol. 2, no. 2, Tbilisi, 2008.

MENDES, Amália. Uma análise dos verbos psicológicos com base nos dados de um corpus: regularidade, variação e polissemia verbal. Em: DUARTE, Inês M. et al. (org.). Encontro comemorativo dos 25 anos do Centro de Linguística da Universidade do Porto, Porto, 22-24 de Novembro de 2001, vol. 1, Porto, Centro de Linguística da Universidade do Porto, p. 21-34, 2002.

MIGLIO, Viola G. et al. Spanish lo(s)-le(s) Clitic Alternations in Psych Verbs: A Multifactorial Corpus-Based Analysis. In: CABRELLI, Jennifer Amaro et al. (eds.). Selected Proceedings of the 16th Hispanic Linguistics Symposium. Somerville, MA: Cascadilla Proceedings Project, pp. 268-278, 2013.

MIURA, Ayumi. Middle English Verbs of Emotion and Impersonal Constructions: Verb Meaning and Syntax in Diachrony. Oxford: Oxford University Press, 2015. 
MOHANAN, K. P. \& MOHANAN, Tara. Dative subjects in Malayalam: Semantic information in syntax. In: VERMA, M. K. \& MOHANAN, K. P. (eds.). Experiencer subjects in South Asian languages. Stanford: CSLI Publications, p. 43-57, 1990.

MOORE, John \& PERLMUTTER, David M. What does it take to be a dative subject? Natural Language and Linguistic Theory 18, p. 373-416, 2000.

MOYSE-FAURIE, C. Impersonal constructions in some Oceanic Languages. In: MALCHUKOV, A. \& SIEWIERSKA, A. Impersonal Constructions: A cross-linguistic perspective. Amsterdam/Philadelphia: John Benjamins, 2011. p.581-606.

MURPHY, Gregory L. The big book of concepts. Cambridge, MA: MIT Press, 2002.

MUSGRAVE, Simon. Non-Subject Arguments in Indonesian. Doctoral dissertation. University of Melbourne, October, 2001.

NASH, Léa. Causees are not agents. Linguistic Perspectives on Causation. HUJI, June 30th, 2017, UP8-CNRS, 2017.

NAESS, Åshild. Prototypical Transitivity. Amsterdam/Philadelphia: John Benjamins Publishing Company, 2007.

NAU, Nicole. Differential Object Marking in Latgalian. In: Holvoet \& Nau (ed.). Grammatical relations and their non-canonical encoding in Baltic. Amsterdam, Philadelphia: John Benjamins, 2014. p.207-255.

NEDJALKOV, V. P. (ed.). Reciprocal constructions. 5 volumes. Amsterdam: John Benjamins Publishing Company, 2007.

NESSET, Tore. Does historical linguistics need the cognitive commitment? Prosodic change in East Slavic. Cognitive Linguistics; 27(4), p. 573-585, 2016

NIZAR, Milla. Dative Subject Constructions in South-Dravidian. University of California, Berkeley. Linguistics Undergraduate Honors Thesis, 2010.

OFFORD, Derek. Using Russian: A Guide To Contemporary Usage. Cambridge University Press, 2005.

ONISHI, Masayuki. Introduction. In: AIKHENVALD, Alexandra Y.; DIXON, Robert M. W.; ONISHI, Masayuki (eds.). Non-Canonical Marking of Subjects and Objects [Typological Studies in Language 46]. Amsterdam/Philadelphia: John Benjamins, p. 1$51,2001$.

PERLMUTTER, David \& POSTAL, Paul M. The 1-Advancement Exclusiveness Law. In: PERLMUTTER, David \& ROSEN, Carol (eds.). Studies in Relational Grammar 2. Chicago: University of Chicago Press. Dordrecht: Kluwer, p. 81-125, 1984.

PESETSKY, David. Binding problems with Experiencer verbs. Linguistic Inquiry 18: p. 126-140, 1987. 
. Zero Syntax: Experiencers and Cascades. Cambridge, MA: MIT Press, 1995.

PIJPOPS, Dirk; SPEELMAN, Dirk. Argument alternations of the Dutch psych verbs. In: Proceedings of QITL 6, 2015.

The influence of agentivity on the argument realization of the psychological verbs: a multivariate regression analysis of the reflexive alternation in Dutch. Em: http://www.ling.arts.kuleuven.be/qlvl/prints/QLVL-share-upcomingPublicationsabstracts .html, 2015.

PINKSTER, Harm. The Oxford Latin Syntax: The Simple Clause, Vol I. United Kingdom: Oxford University Press, 2015.

PONSONNET, M. The Language of Emotions: The Case of Dalabon (Australia). Amsterdam \& Philadelphia: John Benjamins, 2014.

PONTEROTTO, Diane. HAPPINESS IS MOVING UP: Conceptualizing Emotions through Motion Verbs. Selected Papers from the 4th UK Cognitive Linguistics Conference, p. 265-283, 2014.

POSTAL, Paul M. On the surface verb 'remind'. Linguistic Inquiry 1, p. 37-120, 1970.

POSTAL, Paul M. Cross-over phenomena. New York: Holt, Rinehart and Winston, 1971.

PYLKKÄNEN, Liina. On stativity and causation. In: TENNY, Carol L.; \& PUSTEJOVSKY, James (eds.). Events as grammatical objects: The converging perspective of lexical semantics and syntax. Stanford, CA: CSLI Publications, p. 417$444,2000$.

Introducing Arguments. MIT Press, Cambridge, MA, [2002] 2008.

RÁKOSI, György. Dative experiencer predicates in Hungarian. Utrecht: LOT, 2006.

RAUH, Gisa. Syntactic Categories. Their Identification and Description in Linguistic Theories. New York: Oxford University Press, 2010.

RAYFIELD, Donald, et al. (eds). A Comprehensive Georgian-English Dictionary, 2 vols, London: Garnett Press, 2006.

REALI, Florencia; ARCINIEGAS, Catalina. Metaphorical conceptualization of emotion in Spanish: Two studies on the role of framing. Metaphor and the Social World 5:1, p. $20-41,2015$.

REINHART, Tanya. The Theta System-An overview. Theoretical Linguistics 28 3: p. 229-290, 2002.

RICE, Sally. Towards a Cognitive Model of Transitivity. Ph.D. dissertation, University of California, San Diego, 1987. 
RICHARDSON, Kylie R. Case and aspect in Slavic. Oxford: Oxford University Press, 2007.

ROZWADOWSKA, B. Psychological verbs and psychological adjectives. Em: http://uniwroc.academia.edu/BozenaRozwadowska/Papers. (s/d).

Thematic Restrictions on Derived Nominals. In: WILKINS, Wendy (eds.). Thematic Relations, Syntax and Semantics 21, San Diego, CA: Academic Press, p. 147$165,1988$.

Are Thematic Relations Discrete? In: CORRIGAN, Roberta; ECKMAN, Fred; NOONAN, Michael (eds.). Linguistic Categorization, Current Issues in Linguistic Theory 61. Amsterdam/Philadelphia: John Benjamin Publishing Company, p. 115-130, 1989.

. Thematic constraints on selected constructions in English and Polish. Wroclaw: Wydawnictwo Uniwersytetu Wroclawskiego, 1992.

Initial Boundary and Telicity in the Semantics of Perfectivity. In: KOSTA, Peter; BLASZCZAK, Joanna; FRASEK, Jens; GEIST, Ljudmila; ZYGIS, Marzena (eds.). Investigations into Formal Slavic Linguistics. Berlin: Peter Lang, p. 859-872, 2003.

On the onset of psych eventualities. In: CYRAN, Eugeniusz; KARDELA, Henryk; SZYMANEK, Bogdan (eds.). Sound, structure and sense. Studies in memory of Edmund Gussmann. Lublin: Wydawnictwo KUL, p. 533-554, 2012.

RUDZKA-OSTYN, Brygida (ed.). Topics in Cognitive Linguistics. Amsterdam: John Benjamins, 1988.

RULL, Juan, C. P. The conceptualization of emotion as locations in English. RESLA, 14, P.353-363, 2001.

RYAN, N. Russian Genitive: Its forms and usage. Comparative Study of Genitive Case Functions in English and Contemporary Russian. 2nd ed. St. Petersburg: Zlatoust, 2015.

RYLINA, Ganna. Contrastive Study of a perception verb in English and Russian: Feel vs chuvstvovat'. Master Thesis. Universiteit Gent, België, 2013.

SADLER, Misumi. Grammar in use across time and space: deconstructing the Japanese 'dative subject' construction. Amsterdam/Philadelphia: John Benjamns Publishing, 2007.

SANDS, K \& CAMPBELL, L. Non-canonical subjects and objects in Finnish. In: Aikhenvald, A. Y. and Dixon, R.M.W. and Onishi, M. (eds.). Non-canonical Marking of Subjects and Objects. Amsterdam \& Philadelphia: John Benjamins, 2001.

SATO, Yosuke; KISHIDA, Maki. Psychological Predicates and the Point-of-View Hyperprojection. Gengo Kenkyu, 135, p. 123-150, 2009. 
SCHAPPER, Antoinette and HENDERY, Rachel. Wersing. In Schapper, Antoinette (ed.), Papuan languages of Timor-Alor-Pantar: Sketch grammars Volume I. Berlin, Boston: Berlin: Mouton de Gruyter, 2014. p.339-394.

SERZHANT, A. The Independent partitive genitive in Lithuanian. In: Holvoet \& Nau (ed.). Grammatical relations and their non-canonical encoding in Baltic. Amsterdam, Philadelphia: John Benjamins, 2014. p.257-299.

SERZHANT, Ilja A. \& KULIKOV, Leonid (eds.). The Diachrony Typology of Noncanonical Subjects. Amsterdam: John Benjamins, 2013.

SHANIDZE, A. kartuli gramat'ik'is sapudzvlebi, 1: morpologia. (Fundamentals of Georgian grammar, 1: Morphology). Tbilisi: Tbilisis universit'et'is gamomcemloba, 1973.

SHARASHENIDZE, N. Epistemic Modality in Georgian. Verbum, Vol 5 (2014), p. 166-180, 2014.

SHIBATANI, M. Passives and related constructions: A prototype analysis. Language 61 (4), p. 821-848, 1985.

(ed.). Passive and Voice (Typological Studies in Language 16) Amsterdam/Philadelphia:John Benjamins Publishing Company, 1988.

Dative subject constructions twenty-two years later. Studies in the Linguistic Sciences 29 (2), p. 45-76, 1999.

Non-canonical constructions in Japanese. In: AIKHENVALD, A. Y.; DIXON, R. M. W.; ONISHI, M (eds.). Non-canonical marking of subjects and objects. Amsterdam/Philadelphia: John Benjamins, p. 307-354, 2001.

SHIBATANI, M. \& THOMPSON, S. A. (eds.) Grammatical Constructions: Their Form and Meaning. Oxford: Oxford University Press, 1996.

SHOPEN, Timothy (ed.). Language typology and syntactic description, vol. 3: Grammatical categories and the lexicon. Cambridge: Cambridge University Press, 2007.

SRIDHAR, S. N. Dative subjects and the notion of subject. Lingua, 49, p.99-125, 1979.

SWEETSER, E. From Etymology to Pragmatics Metaphorical and Cultural Aspects of Semantic Structure. Cambridge University Press, Cambridge, 1990.

TALMY, Leonard. Lexicalization patterns: Semantic structure in lexical forms. In: SHOPEN, T. (ed.). Language, Typology and Syntactic Description 3: Grammatical Categories and the Lexicon. Cambridge: Cambridge University Press, p. 57-149, 1985.

The Relation of Grammar to Cognition. L.A.U.D.T. Series A; paper no. 165. L.A.U.D. Linguistic Agency, University of Duisburg, 1986. 
TALMY, L. Force Dynamics in Language and Cognition. Cognitive Science, p.49-100, $12,1988$.

Toward a Cognitive Semantics, vol. 1: Concept Structuring Systems. Cambridge,Mass.: MIT Press, and London: Bradford, 2000a.

Toward a Cognitive Semantics, vol. 2: Typology and Process in Concept Structuring. Cambridge, Mass.: MIT Press, $2000 \mathrm{~b}$.

TAYLOR, John. Cognitive Grammar. Oxford Textbooks in Linguistics. Oxford: Oxford University Press, 2002.

. Linguistic Categorization: Prototypes in Linguistic Theory. 3rd ed. Oxford: Oxford University Press/Clarendon, 2003.

TEMME, Anne. German psych-adjectives. In: MACHICAO Y PRIEMER, Antonio; NOLDA, Andreas; SIOUPI, Athina (eds.). Zwischen Kern und Peripherie. Berlin: Mouton de Gruyter, p. 131-156, 2014.

TEMME, Anne; VERHOEVEN, Elisabeth. Backward binding as a Psych Effect: a binding illusion? Berlin-Stuttgart meeting on psych verb. November 21, 2014.

TEZI, Yüksek, L. Psych Verbs in Turkish: a structural and semantic analysis. Dissertation, Mersin, 2004.

TOMLIN, Russell S. \& MYACHYKOV, Myachykov. 2015. Attention and salience. In: DABROWSKA, Ewa \& DIVJAK, Dagmar (eds.). Handbook of cognitive linguistics. Berlin: De Gruyter Mouton, p. 31-52, 2015.

TOPADZE, M. \& RAMAT, A. G. The coding of evidentiality: a comparative look at Georgian and Italian. Rivista di Linguistica 19.1 (2007), pp. 7-38, 2007.

TOPADZE, Manana. On the Way to Evidentiality: Some Observations on Georgian Perfect. International Morphology Meeting Centre of Translation Studies, University of Vienna. 5-6 February, 2008.

TSCHENKÉLI, K. Einführung in die georgische Sprache. Zürich: Amirani Verlag, 1958a. $1958 b$.

Einführung in die georgische Sprache. Band II. Zürich: Amirani Verlag, Georgisch-deutsches Wörterbuch. Zürich: Amirani Verlag, 1960-1974.

TUITE, KEVIN. Indirect transitives in Georgian. Proceedings of the 13th annual meeting ofthe Berkeley Linguistics Society (BLS 13), 296-309, 1987. 
Paradigm recruitment in Georgian. NSL 8: Linguistic Studies in the Non Slavic Languages of the Commonwealth of Independent States and the Baltic Republics, H. Aronson (editor). Chicago Linguistics Society; 375-387,1996

Kartvelian Morphosyntax. Number agreement and morphosyntactic orientation in the South Caucasian languages. (Studies in Caucasian Linguistics, 12). München: Lincom Europa,1998.

Deponent verbs in Georgian. Philologie, Typologie und Sprachstruktur: Festschrift für Winfried Boeder zum 65. Geburtstag, Wolfram Bublitz, Manfred von Roncador, Heinz Vater (ed.), 375-389. Frankfurt am Main: Peter Lang Verlag,2002.

. Liminal morphosyntax: Georgian deponents and their kin. Chicago Linguistics Society, vol 39: 774-788, 2007.

Agentless transitive verbs in Georgian. Anthropological Linguistics, 51 \#3-4: 269-295, 2009.

VERHAGEN, Arie. Construal and Perspectivization. In: CUYCKENS, H. \& GEERAERTS, D. (eds.). The Oxford Handbook of Cognitive Linguistics. New York: Oxford University Press, 2007.

VERHOEVEN, Elisabeth. Experiential Constructions in Yucatec Maya: A typologically based analysis of a functional domain in a Mayan language. Amsterdam/Philadelphia: John Benjamins Publishing Company, 2007.

(Non-)canonical marking of experiencer objects: A typological comparison of Chinese, Korean, Turkish and Modern Greek. STUF 61, p. 81-92, 2008.

Experiencer objects and object clitics in Modern Greek: Evidence from a corpus study. In: 8th International Conference on General Linguistics, 2009a.

Subjects, agents, experiencers, and animates in competition: Modern Greek argument order. In: Linguistische Berichte 219, pp. 355-376, 2009b

Agentivity and stativity in experiencer verbs: Implications for a typology of verb classes. Linguistic Typology 14, p. 213-251, 2010a.

Transitivity in Chinese experiencer object verbs. In: BRANDT, P. \& GARCIA, G. M. (eds.). Transitivity. Amsterdam: John Benjamins, p. 95-117, 2010 b.

Thematic Prominence and Animacy Asymmetries: Evidence from a CrossLinguistic Production Study. In: Lingua 143, pp. 129-161, 2014.

VERMA, Manindra K. \& MOHANAN, K. P. (eds.). Experiencer subjects in South Asian languages. Stanford: CSLI Publications, 1990.

VITI, Carlotta. The morphosyntax of experience predicates in Tocharian. Cahiers de Linguistique Asie Orientale 45, p. 26-70, 2016. 
WIER, Thomas R. Georgian Morphosyntax and Feature Hierarchies in Natural Language. Ph. D.dissertation. University Of Chicago, 2011.

WINTERS, Margaret, E. Introduction: On the emergence of diachronic cognitive linguistics. In: WINTERS, Margaret E.; TISSARI, Heli; ALLAN, Kathryn (eds.). Historical Cognitive Linguistics. Berlin: De Gruyter Mouton, p. 3-30, 2010.

WINTERS, Margaret E.; TISSARI, Heli; ALLAN, Kathryn (eds.). Historical Cognitive Linguistics. Berlin: De Gruyter Mouton, 2010.

WOODS, Christopher. The Grammar of Perspective: The Sumerian Conjugation Prefixes As a System of Voice. Cuneiform Monographs, vol. 32. Leiden: Brill, 2008.

ZEITOUN, Elizabeth; STACY, F. T.; WU, Joy, J. (Eds.). New Advances in Formosan Linguistics. Australia: Asia-Pacific Linguistics, 2015.

ZYCHLINSKI, Sylwiusz. A recalcitrant nature of object experiencers. In: PAWLAK, M. \& BIELAK, J. (eds.), New Perspectives in Language, Discourse and Translation Studies. Berlin: Springer, p. 77-90, 2011.

On some aspects of the syntax of object Experiencers in Polish and English. Doctoral dissertation, Poznan: Adam Mickiewicz University, 2013. 